\title{
LIVRO BRANCO
}

\section{RESPONSABILIDADE EM SAÚDE PÚBLICA}

NO MUNDO LUSÓFONO

FAZENDO JUSTIÇA DURANTE E ALEM DA EMERGÊNCIA DACO TID

André Dias Pereira (Coord.)

Maria do Céu Patrão Neves

Ana Raquel Gonçalves Moniz

Ana Margarida Gaudêncio

Inês Fernandes Godinho

Luís Meneses do Vale

Carla Barbosa

Ana Elisabete Ferreira

Fernando Vannier Borges

Vera Lúcia Raposo

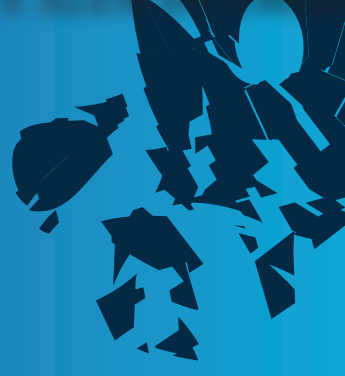

Armindo Jelembi

Sandra Alves

Carlos Serra

Catarina Zamith de Almeida
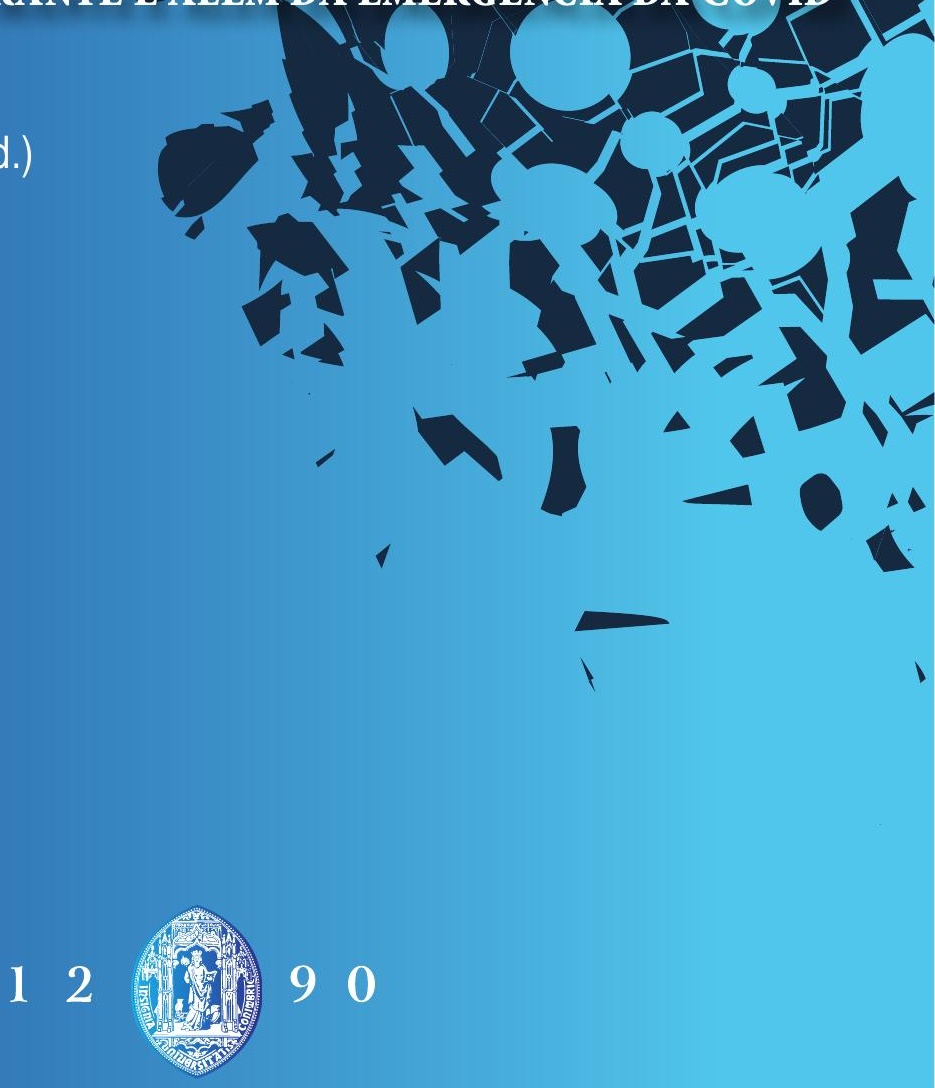

INSTITVTO $\triangle$ IVRIDICO

FACULDADE DE DIREITO

UNIVERSIDADE D

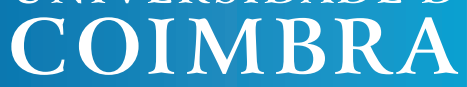

yé Dirhato da saúdo pujbica

$\because *:=$ NOMUNDO IUSOFONO

MARÇO 2021 



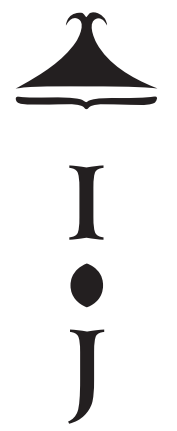


EDIÇÃO

Instituto Jurídico

Faculdade de Direito da Universidade de Coimbra

CONCEPÇÃo GRÁFICA

Frases Favoritas

ISBN

978-989-9075-03-0

DOI

https://doi.org/10.47907/livro2021_01pt

\section{Contactos}

geral@ij.uc.pt

www.uc.pt/fduc/ij

Instituto Jurídico da Faculdade de Direito da Universidade de Coimbra Colégio da Trindade | 3000-018 Coimbra | PORTUGAL 


\section{LIVRO BRANCO}

A Ética da Preparação e Resposta a Emergências de Saúde Pública

\section{RESPONSABILIDADE EM SAÚDE PÚBLICA NO MUNDO LUSÓFONO}

FAZENDO JUSTIÇA DURANTE E ALÉM DA EMERGÊNCIA DA COVID

Projeto Financiado pela Organização Mundial de Saúde WHO ERC number - (CERC.0079/ HEG 70)

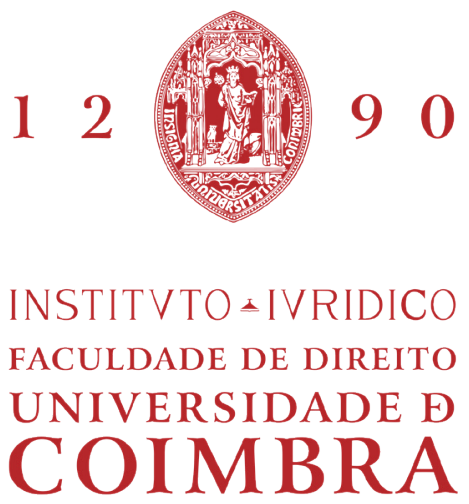





\title{
LISTA DE SIGLAS E ABREVIATURAS
}

\author{
Art. - Artigo \\ CDB - Centro de Direito Biomédico \\ EPI - Equipamento(s) de Proteção Individual \\ OMS - Organização Mundial de Saúde \\ RAEM - Região Administrativa Especial de Macau \\ UE - União Europeia \\ CRP - Constituição da República Portuguesa \\ LBS - Lei de Bases da Saúde
}





\section{ÍNDICE}

Em jeito de Nota de Apresentação

João Carlos Loureiro ................................................................. XI

1. Os desafios da Pandemia por SARS-CoV-2 à Bioética Maria do Céu Patrão Neves................................................... 1 (https://doi.org/10.47907/livro2021_01c1pt)

2. Direitos Humanos e Pandemia Ana Margarida Gaudêncio (https://doi.org/10.47907/livro2021_01c2pt)

3. Direito Constitucional e Pandemia Luis Meneses do Vale.... (https://doi.org/10.47907/livro2021_01c3pt)

4. Direito Público e Pandemia Ana Raquel Gonçalves Moniz.... (https://doi.org/10.47907/livro2021_01c4pt)

5. Direito Sancionatório em Tempos de Pandemia Inês Fernandes Godinho (https://doi.org/10.47907/livro2021_01c5pt)

6. Direitos dos Doentes em Contexto de Pandemia André Dias Pereira, Ana Elisabete Ferreira e Carla Barbosa .... (https://doi.org/10.47907/livro2021_01c6pt)

7. Análise dos Questionários André Dias Pereira e Catarina Zamith de Almeida (https://doi.org/10.47907/livro2021_01c7pt)

8. Bibliografia 
9. Constituiçãa da Equipa .................................................... 149

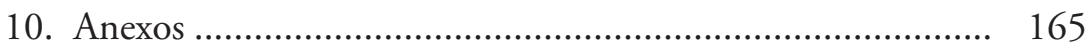

Recomendaçôes ...................................................................... 167 (https://doi.org/10.47907/livro2021_01recpt) 


\section{EM JEITO DE NOTA DE APRESENTAÇÃO}

JoÁo Carlos Loureiro

O Livro Branco que agora se apresenta ao público, académico ou não, é, antes de mais, um ato de prestação de contas de resultados de um projeto de investigação que respondeu a um desafio lançado pela Organização Mundial de Saúde (OMS) em tempos de pandemia. O mote proposto para a investigação foi um amplo The Ethics of Public Health Emergency Preparedness and Response, capaz de acomodar pontes com o direito. O Instituto Jurídico da Faculdade de Direito da Universidade de Coimbra não estava seguramente em branco neste domínio, nomeadamente por via do trabalho, em sede de direito da saúde, dos seus investigadores da área Vulnerabilidade e Direito, mas também de colegas de outras áreas. Aliás, fiel ao seu projeto, que se diz em trilogia - Vulnerabilidade/ Pluralidade/ Indecidibilidade -, o Instituto promoveu, em abril e maio de 2020, um ciclo de conversas em rede, tendo como lema "Pandemia(s), Incerteza e Direito", com quatro encontros: I. Estado de Emergência em Democracia; II. Políticas de Saúde em Tempos de Pandemia; III. Liberdades e Direitos em tempos de confinamentos (Parte 1); IV. Liberdades e Direitos em tempos de confinamentos (Parte 2). Além de artigos dos seus investigadores, publicados em Portugal ou no estrangeiro, surgiu, na coleçáo Desafios Societais e Investigação em Direito, um volume dedicado a Pandemia e Direito.

Não admira, pois, a resposta positiva ao desafio que se concretizou no projeto, financiado pela Organização Mundial de Saúde, intitulado Responsabilidade em saúde pública no mundo lusófono: Fazendo justiça durante e além da emergência da Covid. Contudo, não o fez a partir de um fechar-se, transmutando a Torre da Universidade numa torre de marfim, antes resolveu reforçar as redes que estabelecem pontes no 
mundo lusófono, unido por uma língua que se revela plural nas suas incarnações e reapropriações. Em África, convocámos representantes de Angola (Armindo Jelembi, aliás, investigador do IJ) e Moçambique (Carlos Serra); na América Latina, convidámos um parceiro sólido, a Fundação Oswaldo Cruz (Sandra Alves); na Ásia, estendemo-nos até às Portas do Cerco, para ver, pela máo de Vera Raposo, a experiência da Regiáo Administrativa Especial de Macau (RAEM). Quatro continentes, todos assolados, em maior ou menor grau, pela pandemia e com meios de resposta díspares à crise de saúde pública. Num tempo de neoglobalização, mas tomando a sério a glocalização, esta pandemia comprovou as diferenças e as desigualdades do mundo, também neste campo. Se no século XIX (a primeira Conferência sanitária internacional teve lugar em 1851) os riscos de epidemias impulsionaram significativamente um direito internacional da saúde, nos anos mais recentes tem-se sublinhado o desenvolvimento de mecanismos de governança pós-Vestefália. Apesar das tendências de introversão em alguns países, onde uma velha conceção de soberania é agitada como bandeira, revelando excessos do "globalismo" (a redução da globalização à sua esfera económica, como dizia Ulrich Beck), torna-se claro para muitos que a saúde, para além de um bem pessoal e comunitário, é também um bem público global. Trata-se de responder à pandemia e a responsabilidade não deve ser dita num modo disjuntivo - ou/ ou -, antes exige um $e$, que convoque Estado e sociedade civil, instâncias nacionais e internacionais e supranacionais. Estes tempos de emergência sanitária comprovaram que, se excetuarmos uma retirada para o deserto à maneira dos eremitas, ninguém se salva sozinho. Para garantir immunitas, é preciso mais communitas, um agir em comum, pois a pandemia ri-se das fronteiras dos homens e dispensa passaporte para avançar.

A abertura exprimiu-se também na multiplicidade de saberes. $A b$ initio, o projeto contou com a preciosa colaboração de uma reputada especialista em bioética, Maria do Céu Patrão Neves, Catedrática da Universidade dos Açores. Por via da rede tecida, participaram juristas e profissionais de saúde, académicos e práticos, pessoas da Administração da Saúde e representantes de associaçôes de pacientes. Abertura que se fez comunicação pela arte de Fernando Vannier Borges.

Nesta "sociedade mundial de risco(s)" (Ulrich Beck), também a (bio)ética convocada não deve, sem esquecer as diferenças das realidades nacionais, perder a nota de global. $\mathrm{Na}$ verdade, deve ser global 
quanto ao espaço, falando-se de uma "macroética" da responsabilidade (Karl-Otto Apel), sem que tal seja sinónimo da erosão dos Estados nacionais enquanto comunidades (também de socialidade); ainda global no que toca ao objeto, tendo presente a interação entre homens e animais e, em geral, o ambiente, num tempo de antropoceno.

Também neste plano da realidade, o projeto, no colete de forças do aperto temporal, não se furtou a esforços. Náo caindo na tentaçáo de se limitar a um inventário, mais ou menos comentado, de normas mobilizadas, foi lançado um questionário, que assentou arraiais numa plataforma, tomando-se a sério os dados empíricos. Deste modo, puderam participar na discussão, não apenas académicos, mas servidores públicos, bem como instituiçôes de saúde e Organizaçôes Não Governamentais defensoras dos direitos e interesses dos pacientes. Sem desvelar o sentido dos resultados e concretizar a lista, sempre se dirá que as respostas permitiram unir no mapa todos os territórios envolvidos - Angola, Brasil, Macau e Moçambique e Portugal.

No roteiro proposto, encontramos as seguintes etapas: Maria do Céu Patrão Neves aborda os "Princípios éticos e as limitaçóes impostas pelos Estados em tempos de pandemia”; Ana Gaudêncio analisa a pandemia a partir da perspetiva dos direitos humanos; Luís Meneses do Vale faz a ponte entre Direito Constitucional e pandemia; Ana Raquel Moniz trata da ligação entre Direito Público e pandemia; Inês Godinho foca-se na relação entre Direito Penal e Sancionatório e pandemia; André Dias Pereira, Ana Elisabete Ferreira e Carla Barbosa abordam o tema Direitos dos Doentes e pandemia. No capítulo final, André Pereira e Catarina de Almeida procedem à análise dos questionários.

Na génese da Organização Mundial de Saúde, em 1948, alguns descortinaram utopia na noção abrangente de saúde subscrita, que não a confina a uma leitura médica, antes toma a sério os seus pressupostos. Agora, no quadro da pandemia, numa circunstância onde se fala também de emergência ambiental e se traçam cenários de catástrofe, o tema da apocalítica recebe impulso adicional. Com sabor helénico, apocalipse significa, etimologicamente, tirar o véu, desvelar, e anda associada a imagens de destruição. Apesar da pandemia e dos milhôes de vidas ceifadas, dos doentes que experimentam sequelas e das pessoas que viram o seu quotidiano e os seus modos de existência destruídos, estamos certos de que este náo é o tempo do fim da humanidade, nem esta será a última epidemia. No meio da dor e do sofrimento, assisti- 
mos a um desvelamento: a tese da insularidade de algumas sociedades, nomeadamente do eixo euro-atlântico, não resiste ao teste da realidade.

Começámos este século com o terror do 11 de setembro; experimentámos nas ruas de Paris e de Londres, entre muitas outras cidades, as fragilidades da segurança coletiva; desenham-se cenários de catástrofe ambiental, depois de, após Hiroxima e Nagasáqui, ter passado a pairar sobre a humanidade a possibilidade de uma destruição sem precedentes. A pandemia serviu a muitos, mas não a todos, para pensar na fragilidade da condição humana e nos limites das capacidades tecnológicas.

Não se espera que investigadores do campo da ética ou do direito descubram um fármaco. $\mathrm{O}$ seu contributo, ilustrado nesta obra, passa por pensar quadros normativos, identificar direitos e deveres, avaliar a adequação de normas (materiais, formais, procedimentais e organizacionais) e olhar para as internormatividades. Também a questão da justiça, que comparece no título, merece uma especial atenção quando, aliás, se assinalam os 50 anos da publicação do opus magnum de John Rawls (A theory of justice), ainda que se privilegie, à maneira de Amartya Sen, "uma perspetiva centrada nas realizaçóes".

$\mathrm{Na}$ altura em que escrevemos - março de 2021 -, a incerteza é ainda elevada, assistindo-se a uma série de diferenças no acesso às vacinas; a novas vagas e confinamentos; a uma desordem económica e social muito variável consoante os países, tendo presentes a grande disparidade de meios e possibilidades, o peso do setor informal, as redes de socialidade, etc. Contudo, tendo acompanhado o projeto desde o princípio, nas vestes de Coordenador da área de investigação, mas também com o à vontade de não ser participante, perante os resultados até agora alcançados, que náo se esgotam nesta obra, temos desde já a certeza da concretização, impondo-se uma palavra de agradecimento aos participantes: aos que elaboraram o projeto (no caso de André Dias Pereira, acresce a tarefa da coordenação) e aos que se dispuseram a participar, seja apresentando comunicaçôes seja respondendo ao questionário.

Ao(s) leitor(es), cabe agora, como habitualmente, avaliar a obra e, se quiser(em), prosseguir o diálogo. Além do mais, a saúde, como recorda a Constituição da República Portuguesa, no art. 64. \%/1, não se diz apenas em registo de direitos, pois "todos têm (...) o dever de a defender e promover". 


\title{
1. OS DESAFIOS DA PANDEMIA POR SARS-COV-2 À BIOÉTICA
}

\author{
Maria do Céu Patráo Neves
}

Uma pandemia é sempre uma situação rara e extrema. Uma pandemia num mundo globalizado, sem fronteiras, como este em que vivemos, é uma situação inédita que se torna ainda mais extrema, colocando necessariamente em causa os padrốes habituais de acção que parecem então inexorável e frustrantemente desfasados da realidade.

As interrogações sobre o sentido mais adequado da acção começam por ser técnicas, isto é, de carácter operativo, relativas aos procedimentos devidos nas várias situaçóes excepcionais que vão ocorrendo, mobilizando os recursos humanos, de equipamentos, financeiros, legislativos existentes. Porém, quaisquer recursos tendem a esgotar-se rapidamente perante o aumento exponencial de carências a satisfazer num curto período de tempo e sempre sob o imperativo da urgência. Neste contexto de grave escassez de recursos depressa as questóes técnicas se tornam iminentemente éticas, uma vez que é a ponderação de factores especificamente humanos e em particular os valores implicados nas diversas formas de actuação que se tornam determinantes nas decisóes a tomar. Posteriormente, também a intervenção do Direito se torna indispensável, na regulamentação jurídica da prévia ponderação técnica e ética. Foi esta extraordinária realidade da pandemia de SARS-CoV-2 que se nos foi tornando quotidiana.

A bioética, como ética aplicada às ciências biomédicas a partir da perspectiva da sociedade, isto é, como ética cívica, foi, pois, chamada a intervir como contributo decisivo para a resolução de problemas humanos inéditos e dramáticos, numa recuperação do espírito originário que a desencadeou, no século passado, como um saber transdisciplinar e uma prática concreta e eficaz. Esta sua intervenção, fiel às suas 
características identitárias, foi tão intensa neste tempo de pandemia quanto ampla na diversidade temática que contemplou e no número de bioeticistas que mobilizou.

Procurando proporcionar uma visão abrangente, não obstante sinóptica, desta acção alargada da bioética, importará sistematizá-la, o que fazemos em dois primeiros grandes planos fundamentais: um ao nível micro, na sua atenção às pessoas singulares, e outro ao nível macro, no seu empenhamento nos problemas comunitários, partilhados. Ambos se vão desdobrando numa panóplia de questôes que procuraremos igualmente sistematizar nas suas vertentes mais expressivas e também de maior impacto.

\section{Intervenção ao nível micro: atenção à pessoa singullar}

Definimos já o plano micro de actuação da bioética como aquele caracterizado pela sua incidência nas pessoas singularmente consideradas. Neste plano, a bioética tem tido uma intervenção especialmente relevante (1) tanto na elaboração de critérios de priorização de pessoas no acesso a bens de saúde, (2) como na legitimação de restriçóes aos direitos individuais, civis, em prol da protecção da saúde pública.

Foi precisamente neste nível micro de intervenção que, na cronologia da pandemia, primeiramente se formularam problemas graves a exigirem a ponderação bioética. Referimo-nos em particular ao do acesso a cuidados intensivos e a ventilação invasiva, quando, desde a primeira vaga na Europa, em Março e Abril de 2020, não existiam ventiladores em número suficiente para todos os doentes. Aliás, já nas semanas anteriores era evidente a falta de máscaras cirúrgicas, de luvas, gel desinfetante ou mesmo álcool para a população em geral, e também de material protetor para profissionais de saúde. Mais tarde, com o surgimento de novas estirpes do vírus e o agravamento da situação sanitária em todo o mundo, verificou-se a falta de oxigénio para doentes graves, nomeadamente no Brasil, e também uma acentuada escassez de camas e mesmo de profissionais de saúde para assegurar o tratamento adequado a todos os doentes. Mais recentemente a questáo dos critérios de priorização de pessoas colocou-se perante a necessidade de vacinar toda a população, tornando-se cada vez mais evidente a insuficiência dos actuais níveis de produçáo de vacinas e a consequente inevitabilidade do seu racionamento. 
A priorização de pessoas no acesso aos bens de saúde existentes exige uma ponderação sobre os critérios a aplicar os quais, devendo fundamentar-se numa análise objectiva da situação real, não prescindem da consideração de factores de natureza pessoal. Tal constitui inexoravelmente um desafio para o respeito pelo princípio da dignidade humana o qual enuncia o valor absoluto e incondicionado de cada uma e todas as pessoas. Neste plano, podemos considerar o factor específico da "idade" particularmente interessante pela discrepância na sua valorização em situaçôes diversas e pela gravidade do peso que adquire em algumas circunstâncias. Com efeito, a "idade" tem sido utilizada para excluir pacientes dos cuidados intensivos, de que carecem, em fases de míngua de vagas, e tem sido utilizada para atribuir prioridade no acesso às vacinas, sobretudo quando o seu número é escasso: no primeiro caso, com a justificação de que os idosos terão menos tempo de vida (importa "salvar anos de vida"), na aplicação do princípio da utilidade, ou da máxima utilidade para o maior número de pessoas, válido para a distribuição de bens, mas não para a exclusão de pessoas, o que implicaria a sua objectivação; no segundo, porque estão em maior risco de vida (importa "salvar vidas"), vingando o princípio da vulnerabilidade na obrigatoriedade de cuidado proporcional à respectiva vulnerabilidade. A incoerência é evidente e a reflexão ética urgente, sendo que, valendo todas as vidas o mesmo, isto é, valendo todas absolutamente, a contabilidade de anos de vida para consideração da tentativa de a salvar constitui uma violação grosseira da dignidade humana.

A este nível micro, a bioética tem também investido na apreciação de medidas de saúde pública com forte impacto nos direitos (de primeira geração) individuais dos cidadáos, particularmente na sua liberdade individual, ou autonomia, na capacidade de decidir por si o que a si lhe diz respeito, e na sua privacidade, ou reserva da vida pessoal de cada um. Referimo-nos, por exemplo, à imposição de quarentenas e de isolamentos profiláticos, à identificação de todos os contactos de risco de infectados, à obrigatoriedade de mediçáo da temperatura ou de apresentação de teste negativo para acesso a espaços circunscritos. A questáo fundamental que se coloca é a da legitimidade ética e da autoridade legal para a redução dos direitos individuais.

A legitimidade tem sido argumentada em termos de bem comum ou conjunto de condiçôes (tangíveis e intangíveis) de vida partilhada que promovem o desenvolvimento, a realização da pessoa, singular e 
comunitariamente considerada. Assim sendo, cada cidadão é chamado a aceitar suspender alguns dos seus direitos como contributo individual para a promoção do bem-estar geral da comunidade a que pertence e de que beneficia também. Afinal, a autonomia não pode ser perspectivada como um conceito abstrato e desenraizado, antes se exercendo situada num espaço, tempo e circunstâncias concretas, o que se traduz pela sua indissociabilidade da responsabilidade social, ou obrigação de responder às necessidades e expectativas da sociedade na justa medida do seu respectivo poder. De facto, ninguém vive só e todos nos encontramos incrustados em inúmeras redes de dependências, num entrelaçado de direitos e deveres.

Prolongando o raciocínio, poder-se-ia argumentar que o gozo dos direitos individuais poderia ficar radicalmente comprometido sem a suspensão provisória dos mesmos, sem a assunção dos deveres de cada um como contributo para o bem-comum: se não se limitar as cadeias de contágio, todos os cidadáos individualmente considerados terão um risco acrescido de infecção e respectivas consequências imprevisíveis. Neste contexto, a autoridade para impor restriçôes aos direitos individuais só poderá pertencer a representantes do bem comum, do bem social, ou seja, a instituiçóes e ao próprio governo.

\section{Intervenção ao nível macro: atenção à comunidade de pertença}

Definimos já o plano macro de actuação da bioética como aquele caracterizado pela sua incidência nas comunidades e nos problemas partilhados pelos seus membros, os cidadãos. Neste plano, a bioética tem tido uma intervenção especialmente relevante (1) tanto na legitimação de restriçôes aos direitos sociais em prol da protecção da saúde pública, (2) como na exigência de cooperação e solidariedade internacionais.

À semelhança do que ao nível micro apontámos como restriçôes aos direitos individuais, também ao nível macro nos deparamos com as limitaçóes ao gozo dos direitos humanos como os primeiros problemas éticos a manifestarem-se na cronologia da pandemia. Referimo-nos ao confinamento geral da população e à imposição de cercas sanitárias, ao encerramento da quase totalidade das actividades económicas e à imposição do teletrabalho. Diferentemente do que se verificava no plano micro, em que se reduziam as obrigaçóes negativas do Estado, na 
sua obrigatoriedade de não-ingerência na esfera privada do cidadão, no plano macro o Estado tem obrigaçóes positivas, isto é, tem o dever de construir condiçóes para o desenvolvimento social e económico da população, o que tem sido gravemente comprometido pelo impacto socioeconómico das medidas sanitárias. Atendendo a que estes são direitos de segunda geraçáo, que se revestem de uma obrigatoriedade positiva, os Estados têm o dever de implementar compensaçóes mitigadoras dos impactos negativos da pandemia, o que concorre para a legitimação das medidas impostas.

Simultaneamente, importa considerar que as medidas sanitárias não têm um mesmo impacto em toda a população: por exemplo, há trabalhadores em plena actividade (como profissionais de saúde), em teletrabalho (como professores), em lay-off (como funcionários da restauração) e inactivos sem qualquer compensação (como artistas). Realidades sociais como esta evidenciam a urgência de implementaçáo do princípio da justiça como equidade, isto é, numa igual ou equilibrada distribuiçáo dos prejuízos causados pela pandemia e das compensaçóes atribuídas pelo Estado. Acresce ainda um outro importante problema adicional a considerar relativo a novas modalidades de discriminação de pessoas, como tem acontecido com os idosos encerrados em lares e isolados de todo o contacto familiar, e de estigmatização de grupos, como tem acontecido em bairros de maior densidade populacional e maior propagaçáo da doença cercados por uma cerca sanitária. A equidade, a não-discriminação e a não-estigmatização são normativas do princípio da justiça, como obrigatoriedade de "tratar igualmente os iguais e desigualmente os desiguais, na medida de sua desigualdade", na enunciaçáo da sua designada "regra de ouro", táo formal e abstracta, quanto ampla e consensual.

Também a este nível macro a questão fundamental que se coloca é a da legitimidade ética para a redução de alguns direitos socioeconómicos, como o do trabalho, em prol de outros, como o da saúde pública. O princípio ético fundamental a considerar é o da proporcionalidade o qual exige que: a intervenção do Estado se limite ao mínimo necessário e indispensável (na amplitude das medidas e período temporal) para garantir o bem comum; as restriçôes e interdiçôes sejam cientificamente justificadas e apresentadas com objectividade e transparência (a forma e o conteúdo da intervenção devem estar subordinados e limitados ao fim estabelecido); e as medidas adoptadas obtenham o consenso da população. 
Ainda a este nível a bioética tem também investido no plano das relaçóes internacionais, no contexto global, atendendo aos direitos de terceira geração, ou de titularidade colectiva, e considerando os princípios da solidariedade e cooperação, entre os vários países do mundo e em particular os em vias de desenvolvimento, e de partilha de benefícios decorrentes dos progressos da investigação científica e em prol da saúde global. Neste âmbito referimo-nos a realidades aparentemente distintas como sejam: na primeira fase da pandemia na Europa, frequentes desvios de bens de saúde primários adquiridos na China, quer sob a forma de desrespeito de contratos de promessa de compra e venda ultrapassados por leilóes em bastidores, quer mesmo pela retenção de avióes de carga e usurpaçáo dos bens transportados, por parte de alguns países em que o transporte fazia escala; mais recentemente, e numa dimensão bem mais ampla, a luta pela compra das vacinas disponíveis por avultadas somas de dinheiro, elevando o preço de mercado a valores incomportáveis para a maior parte dos países, e ainda a sua pré-aquisição em volumes que ultrapassam as necessidades da população dos respectivos países, deixando outros sem perspectivas realistas de poderem vacinar a sua população num futuro próximo. Estes procedimentos desenrolam-se numa lógica de poder, de competiçáo e de açambarcamento, frontalmente contrária à lógica da acção ética, de cooperação e partilha.

\section{A superação de confflitos por concilliaçáo}

A enunciação de princípios éticos em que se procura fundamentar e legitimar uma panóplia de intervençóes neste tempo de pandemia não é só por si suficiente para estabelecer um curso de acção eticamente sustentável. Com efeito, a sua consideração, nos níveis micro e macro, não evita que protagonizem dilemas, isto é, que se apresentem como duas ou mais obrigaçóes que entram em conflito entre si por ser impossível cumpri-las simultaneamente. A escolha de uma única, porém, implicará sempre o fracasso da outra, a qual, não obstante, é igualmente uma obrigação a cumprir. Poderíamos apontar, como exemplo, o conflito entre a autonomia individual e a responsabilidade social, a nível micro, e o conflito entre o direito à saúde, à sua protecção, e o direito ao trabalho, a condiçóes materiais para um padrão de vida que assegure o bem-estar individual e da família, a nível macro. Precisamos, pois, também, de uma metodologia de ponderação dos princípios na sua 
aplicação à realidade concreta, que adopte uma lógica inclusiva, que, a cada momento, equilibre os princípios em presença, na maximização dos valores que protagonizam e estão em conflito, nomeadamente o exercício livre da vontade e a protecção da saúde.

O imperativo ético não se coloca, pois, apenas na identificação de princípios estruturantes da acção, mas também na formulação de metodologias da sua articulação; e os critérios éticos a estabelecer não são essencialmente de selecção, mas igualmente de conciliação, num desafio obviamente superior ao primeiro. Neste plano, importa:

(1) considerar objectiva e rigorosamente a realidade em que urge intervir (e.g. pandemia);

(2) avaliar a bondade dos fins, da finalidade da acção (e.g. tendencialmente eliminar os contágios/infecçóes);

(3) identificar as obrigaçōes expressas pelos princípios de acção a respeitar (e.g. autonomia individual e bem comum ou social) e o eventual conflito entre alguns (e.g. liberdade e confinamento);

(4) ponderar o peso moral de cada uma das obrigaçóes em conflito (e.g. o exercício da liberdade fica comprometido na ausência de saúde) e formular modalidades de acção intermédias que procurem respeitar ambas (e.g. medidas de confinamento mais restritivas, como a cerca sanitária, para quem representa risco maior);

(5) manter o compromisso em relação às obrigações não cumpridas, reduzindo o período de não-cumprimento, mitigando as consequências negativas, compensando os prejuízos, etc. (e.g. regime de lay-off ou emissão de moratórias).

A deliberação ética terá, pois, de ser inclusiva, exigindo a consideração da totalidade dos valores implicados, conciliatória, centrada na sua possível articulação, e abrangente, mantendo o compromisso com todos e realizando-os maximamente. Eis o que contribuirá para a construção do mais amplo consenso social, à margem do qual dificilmente a ética poderá subsistir na sua autenticidade como relação não-violenta.

São estes os mais elementares requisitos éticos para toda e qualquer limitação a impor aos direitos humanos, civis e políticos, socioeconómicos e de titularidade colectiva. 


\section{Do consenso ético à regulação jurrídica, à implementaçáo política}

A bioética, na sua intervenção a nível micro e macro, através da enunciação dos princípios fundamentais a respeitar e do imperativo da sua constante harmonização, estabelece as condiçóes mínimas de legitimidade ética para a restrição, provisória e proporcional, dos direitos humanos, em tempo de emergência sanitária, bem como da autoridade dos Estados para a respectiva iniciativa legislativa e a implementaçáo política.

A reflexão ética terá, pois, de estar na base e constituir a estrutura do processo de tomada de medidas sanitárias que, involuntária mas consequentemente, limitem os direitos dos cidadãos e das comunidades. Por sua vez, é fundamental que os consensos sociais alargados para que a bioética contribui, venham a ser revestidos com a força da lei. Isto é, importa passar das recomendaçóes dirigidas à boa vontade de cada um, de forma inconsequente, para o estabelecimento de práticas obrigatórias e cuja infracção é sancionada. Por exemplo, existindo amplo consenso acerca do elevado valor profilactico do uso das máscaras, este não poderá permanecer voluntário, sob pena de ser ineficaz, e terá de se tornar obrigatório para efectiva protecção das pessoas.

A sequência da ética para o direito garante que a lei não se abate sobre o cidadáo e sobre as comunidades, de cima para baixo, numa dinâmica de poder, prepotente e agressiva, mas antes é reclamada pelas pessoas, como uma medida de protecção desejada, num processo que vai de baixo para cima. A legislação excepcional em tempo de pandemia responde assim às necessidades e expectativas, às aspiraçóes da sociedade, revestindo-se de uma indelével legitimidade ética.

Por sua vez, a implementação política apresenta-se como um sucedâneo indispensável e urgente, evidenciando que as medidas restritivas não são avulsas, podendo tornar-se facilmente discriminatórias, mas antes integram uma estratégia justificada e consistente para a prossecução do valor social superior e comummente desejado, neste caso da saúde.

O processo ético descrito e o seu desenvolvimento no plano jurídico e político estabelecem o perímetro de legitimidade para a dureza das medidas sanitárias desde que se mantenham dentro dos parâmeros traçados da sua proporcionalidade e do seu compromisso para com a mais rápida e plena observância da moral comum universal dos Direitos Humanos. 


\section{DIREITOS HUMANOS E PANDEMIA}

Ana Margarida Gaudêncio

\section{Pluralismos, pandemias e direitos}

A crise pandémica que surpreende e assola o mundo há agora já mais de um ano veio reexpor e agudizar, em múltiplos sentidos, a sinalizaçáo de fragilidades e limitaçóes nas actuais sociedades, plurais-pluralistas, heterogéneas, complexas... O pluralismo - de demandas, convicçôes, ideologias, identidades, vulnerabilidades... - contemporaneamente afirmado - e, assim, anterior à e independente da actual pandemia - espelha a crescente pulverizaçáo dos fundamentos materiais da interacção social, alargando-se progressivamente a afirmação individualista de direitos e liberdades nas relaçôes intersubjectivas, numa teia crescentemente complexa de opçôes e sentidos que poderão potencialmente coexistir pacificamente desde que procedimentalmente compossibilitados num grau mínimo de delimitaçáo. O que poderá implicar o empobrecimento, quando não mesmo a aniquilação, da dimensão especificamente normativa que ao direito se atribui como crucial dimensão histórico-cultural, selectivamente valoradora e reguladora da praxis intersubjectiva. Desvanecendo-se progressivamente as dimensöes de absoluto nas culturas pluralistas, digladiam-se múltiplas opçōes culturais diversas em diferentes sociedades ${ }^{1}$.

$\mathrm{O}$ vocábulo pandemia, metáfora agora de realidade, tem atravessado como intempérie o planeta e a humanidade: um minúsculo, invisível, virus, desconhecido e inesperado, como um acontecimento-Ereignis,

1 Neste sentido, vide Hans-Jörg SANDKüHLER, "Pluralism, Cultures of Knowledge, Transculturality, and Fundamental Rights", in Hans-Jörg Sandkühler/Hong-Bin Lim (Ed.), Transculturality: Epistemology, Ethics and Politics, Peter Lang, Frankurt, 2004, p. 79-100, p. 93. 
para o dizer com Heidegger ${ }^{2}$... assim rapidamente instalado, juntamente com o espanto, a (in)compreensáo, o medo, e as pluralidades de discursos... e obrigando ao afivelamento de múltiplas máscaras... estas, afinal, não sempre, e não necessariamente, fazendo do ser humano persona, mas afigurando-se cada vez mais, pelo menos, como meio, já de protecção, física, ou não, já de discrição, já de isolamento...

A urgência de regulaçáo jurídico-política da situação excepcional provocada pela pandemia de COVID-19 tem gerado nos sistemas jurídicos múltiplas dúvidas, por um lado, e múltiplas críticas, por outro, manifestando-se aquelas e estas, afinal, como outras pandemias, capazes de dificultar, se não mesmo bloquear, a compreensão da gravidade da situação e a adequada mobilização de meios para o respectivo enfrentamento. Refira-se, desde logo, e apenas exemplarmente, a pandemia da desinformação. A constitucionalmente consagrada liberdade de expressão e de informação, princípio e direito humano e fundamental, quer enquanto direito de informar quer enquanto direito a ser informado, pulverizou a circulaçáo de conteúdos (des)informativos a uma escala sem precedentes, tanto oficial como oficiosamente, pondo directamente em causa a também constitucionalmente consagrada segurança, também princípio e direito fundamental, directamente enquanto tal, e ainda enquanto trabalhadores, consumidores, utentes de serviços públicos, também dos de saúde... Além disso, haverá que considerar, também apenas exemplarmente, a pandemia da excepcionalidade. $\mathrm{Na}$ encruzilhada entre pandemia e direito, ameaçando tornarem-se ténues, se não difusas, as limitaçôes às limitaçôes, cumprirá reforçar que, no âmbito de um Estado de Direito democrático, a discussão sobre a delimitação de direitos e de deveres se sustenta no e através do pressuposto de que as restriçóes aos direitos e liberdades dos cidadãos, ainda que pondo o(s) direito(s) em situação de excepção, não constituirão situação de excepção ao(s) direito(s).

2 Vide Martin Heidegger, Beiträge zur Philosophie. Vom Ereignis (1936-1938), in Friedrich-Wilhelm von Herrmann (Hrsg.) Gesamtaugabe, III. Abteilung: Unveröffentlichte Abhandlungen, Band 65, Vittorio Klostermann, Frankfurt am Main, 1989, 1994, 2003, p. 7, 23-35, 73-78, 80-83, 84-87. 


\section{Direitos bumanos em pandemia}

No centro de tais vicissitudes, a pandemia de COVID-19 introduziu, nas múltiplas vertentes em que se desenvolveu, o questionamento dos próprios pressupostos culturais da intersubjectividade. Em consequência, a plasticidade reflexiva assumida pela regulação jurídica face à exigência de rapidez e eficiência perante a progressáo da pandemia projecta-se no questionamento dos próprios fundamentos, significados e limites da referenciação jurídica da ideia de direito e de direitos humanos, e, assim, subjectivamente, de pessoa jurídica - enquanto titular de direitos e deveres -, e, objectivamente, de normatividade jurídica enquanto racionalizaçáo prática e substancialmente autónoma de um específico domínio e sentido de intersubjectividade. Neste contexto, à luz de uma reperspectivação das determinaçóes substancialmente densificantes dos chamados direitos humanos no actual circunstancialismo, estão efectivamente em causa as tradicionalmente convocadas perspectivaçóes da natureza dos assim ditos direitos humanos - partindo da distinção entre perspectivas naturalistas e perspectivas políticas, e, essencialmente imbricada naquela, a distinção entre direitos humanos como direitos morais, políticos e jurídicos - e do respectivo âmbito de relevância - partindo da distinção entre universalismo(s) e relativismo(s), expondo associadamente o problema da culturalidade ou aculturalidade dos direitos humanos ${ }^{3}$. Entre um relativismo extremo e um universalismo irredutivel, as tentativas de discernir um núcleo comum e uma ramificação diferenciada de direitos humanos, face às dificuldades de apresentação de densificaçôes universalizáveis, visam hoje a assimilação da concretização material do sentido de humanidade, nas inumeráveis perspectivaçôes sincrónica e diacronicamente em presença. O que será dizer que, em torno de um núcleo de humanidade comum - não obstante de evolução e conteúdo necessária e absolutamente variável, e sem redução a um comum definido por um qualquer cosmopolitismo -, se desenvolverão múltiplas periferias de densificação particularizada de afirmaçóes positivas de direitos - mas também, no seu verso, e ainda

3 Rowan Cruft, S. Matthew Liao, Massimo Renzo, The Philosophical Foundations of Human Rights: An Overview, in Rowan Cruft, S. Matthew Liao, Massimo Renzo (Ed.), Philosophical Foundations of Human Rights, Oxford, Oxford University Press, 2015, p. 1-41. 
positivamente, de deveres - dificilmente descontextualizáveis ${ }^{4}$. E, não obstante, afirmados como direitos, e humanos, enquanto representação da mais alta referência à humanidade e à sua dignidade, que a institucionalização da Declaração Universal dos Direitos do Homem, de $1948^{5}$ - depois complementada pelo Pacto Internacional sobre os Direitos Civis e Políticos ${ }^{6}$ e pelo Pacto Internacional sobre os Direitos Económicos, Sociais e Culturais $^{7}$, ambos de 1966 -, veio, em substituição da moderna Déclaration des Droits de l'Homme et du Citoyen, de 1789, reposicionar e enfatizar na questão dos direitos humanos, à luz dos acontecimentos da Segunda Guerra Mundial, abrindo novas geraçôes dos mesmos $^{8}$, estabelecendo como pilar fundamental essas noções de humanidade e de dignidade - logo no artigo 1.\%/1: «Todos os seres humanos nascem livres e iguais em dignidade e em direitos. Dotados de razão e de consciência, devem agir uns para com os outros em espírito de fraternidade».

$\mathrm{Na}$ actual situação de pandemia, concentrando-se a problemática e os discursos de direitos humanos na saúde pública, nacional e internacional, é a própria noção de saúde como direito humano que é posta em causa, enfatizando decisivamente a relevância, no seu conteúdo e na sua estrutura, do direito internacional da saúde pública ${ }^{9}$. As bases de sustentação da relevância da saúde como direito humano encontram-se, desde logo,

4 Vide José Carlos Vieira de Andrade, Os direitos fundamentais na Constituição

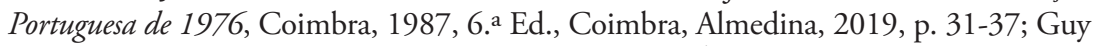
Haarscher, Philosophie des droits de l'homme, Bruxelles, Éditions de l'Université de Bruxelles, 1987 (Ed. revisée 1993), especialmente p. $41-45$ e 119-124; Patrícia Jerónimo, Os Direitos do Homem à escala das Civilizaçôes, Coimbra, Almedina, 2001, p. 259-260.

5 Declaração Universal dos Direitos Humanos, 1948 (https://dre.pt/declaracao-universal-dos-direitos-humanos).

6 Pacto Internacional sobre os Direitos Civis e Politicos, 1966 (https://dre.pt/application/conteudo/426144).

7 Pacto Internacional sobre os Direitos Económicos, Sociais e Culturais, 1966 (https://dre.pt/application/file/a/297973).

8 Vide Mário Reis Marques, Introdução ao Direito I (Figueira da Foz, 1992),

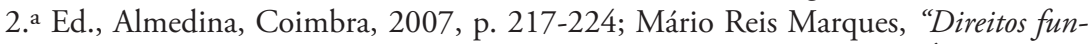
damentais e afirmação de identidades", in Economia e Sociologia, n. o 80, Évora, 2005, p. 157-169, p. 163-166. Vide ainda Ghislain Waterlot, "Human Rights and the Fate of Tolerance", in Paul Ricoeur (Ed.), Tolerance Between Intolerance and the Intolerable, Providence, Oxford, Berghahn Books, 1996, p. 53-70, p. 60-65.

9 Brigit Toebes, "International Health Law: An Emerging Field of Public International Law", in Indian Journal of International Law, 55(3), 2015, p. 299-328 [DOI 10.1007/s40901-016-0020-9]. 
na própria Declaração Universal dos Direitos Humanos, no seu artigo 25. /1: "Toda a pessoa tem direito a um nível de vida suficiente para lhe assegurar e à sua família a saúde e o bem-estar, principalmente quanto à alimentação, ao vestuário, ao alojamento, à assistência médica e ainda quanto aos serviços sociais necessários, e tem direito à segurança no desemprego, na doença, na invalidez, na viuvez, na velhice ou noutros casos de perda de meios de subsistência por circunstâncias independentes da sua vontade". Por sua vez, o Pacto Internacional de Direitos Civis e Políticos afirma, no artigo 6.\%/1: "O direito à vida é inerente à pessoa humana. Este direito deve ser protegido pela lei: ninguém poderá ser arbitrariamente privado da vida”. E, adicionalmente, o artigo 12. o/1 e 2 c) e d) do Pacto Internacional de Direitos Económicos, Sociais e Culturais estabelece: "1. Os Estados Partes no presente Pacto reconhecem o direito de todas as pessoas de gozar do melhor estado de saúde física e mental possível de atingir. 2. As medidas que os Estados Partes no presente Pacto tomarem com vista a assegurar o pleno exercício deste direito deveráo compreender as medidas necessárias para assegurar: [...] c) A profilaxia, tratamento e contrôle das doenças epidémicas, endémicas, profissionais e outras; d) A criação de condiçôes próprias a assegurar a todas as pessoas serviços médicos e ajuda médica em caso de doença”.

Pressupondo o direito à saúde como um direito humano a compreensão do(s) sentido(s) de "direito humano" que lhe subjaz, acentua-se aqui especificamente quanto a esta noção a proposta de Brigit Toebes - na pressuposição da noção de direitos humanos apresentada por Charles C. Beitz -, considerando os direitos humanos como normas que reflectem “interesses individuais urgentes", isto é, interesses cuja protecção seja suficientemente relevante ao ponto de a ausência dessa protecçáo ser uma questão de relevo internacional ${ }^{10}$. Neste sentido, é a própria noção de "saúde", ou de "boa saúde", que é discutida, assumida como interesse individual urgente, e cuja proteçáo se reveste de relevância decisiva quer para os indivíduos quer para a comunidade internacional ${ }^{11}$. O que é certificado pelo papel fundamental desempenhado pela Organização

10 Brigit Toebes, "International Health Law: An Emerging Field of Public International Law", p. 302-303, referring to Charles C BeITz, The Idea of Human Rights, Oxford, OUP, p. 137.

11 Brigit Toebes, "International Health Law: An Emerging Field of Public International Law", p. 303, referring Brigit Toebes, "Introduction", in Brigit Toebes et al., Health and Human Rights in Europe, Antwerp, Intersentia, 2012, 13, 15-16. 
Mundial de Saúde na gestão da saúde em termos globais, e tem sido particularmente destacado desde a declaração da COVID-19 como uma pandemia, em 11 de março de $2020^{12}$.

Acentuando progressiva e indiscutivelmente a relevância da saúde pública como problema global - quanto ao acesso a unidades de saúde, a tratamento e a vacinação -, a pandemia de COVID-19 acarreta múltiplas outras consequências ao nível da protecção dos direitos humanos, em muitas outras dimensôes e com repercussóes muito distintas em diferentes locais do globo. Naturalmente, a polissemia do vocábulo saúde, e, assim, a abrangência da noção de saúde, como ponto(s) de referência, exigirão, do ponto de vista dos direitos humanos, uma inevitável consideração estrutural multinível e um tratamento específico de cada questão, na sua relevância social e cultural, o que é compreendido e concretizado diferentemente consoante as matrizes culturais ${ }^{13}$.

Mais do que uma discussão sobre o valor e a relevância dos direitos humanos, o que estará agora em jogo será a reflexão sobre a existência de condiçôes formais e materiais para lograr a manutenção dos objectivos civilizacionalmente assumidos como concretização dos direitos humanos em ambientes culturais e políticos muito diversos. Tece-se presentemente uma profunda revisão dos hábitos humanos, tanto individuais como nas relaçôes sociais, em projecção dos discursos políticos, também sobre direitos humanos, e da efectivação de políticas públicas relativas à pandemia, muito para lá das directas implicaçóes do contágio, do tratamento e da vacinação. Num sistemático (re)posicionamento crítico-reflexivo dos problemas relativos aos direitos humanos, estarão imbricados, principalmente, e sob escrutínio, crucialmente, os seguintes núcleos problemáticos: por um lado, o direito à saúde ${ }^{14}-$ fí- $^{\prime}$ sica e mental -, e, em consequência, o direito à educaçãa ${ }^{15}$ - do acesso à educaçáo à (im)possibilidade do ensino a distância - e à protecçáo social ${ }^{16}$ - face ao trabalho, ao abandono, ao isolamento, à criminalida-

12 Vide https://www.who.int/director-general/speeches/detail/who-director-general-s-opening-remarks-at-the-media-briefing-on-covid-19---11-march-2020. Vide ainda, exemplarmente, os relatórios de 2021 da organização Human Rights Watch sobre a situação pandémica: https://www.hrw.org/world-report/2021.

13 James R. MaY/Erin DaLY, "Dignity Rights for a pandemic", in Law, Culture and the Humanities, 2020, 1-20 (DOI: 10.1177/1743872120944515).

14 Artigo 25. o/1 da Declaração Universal dos Direitos Humanos.

15 Artigo 26. ${ }^{\circ}$ da Declaraçáo Universal dos Direitos Humanos.

16 Artigos 23..$^{\circ}$ e $25 .^{\circ}$ da Declaraçáo Universal dos Direitos Humanos. 
de... -; e, por outro lado, e decisivamente, os direitos à liberdade ${ }^{17}$ política, de informação, de expressão, de circulação... - e à segurança ${ }^{18}$ - do direito e perante o direito.

\subsection{Saúde}

Efectivamente, é de um problema de saúde, primeiramente, que se tratará, enquanto ponto de referência essencial e condicionador dos restantes na actual circunstância. Para lá dos múltiplos efeitos directos causados pelo contágio com o vírus SarsCov-2, é a saúde, física e mental, individual e global, dos seres humanos que está em causa. Embora a Organização Mundial de Saúde defina "saúde" como "completo bem-estar físico, mental e social"19, o conceito de "saúde" apresenta-se multifacetado e complexo - "ter saúde" e "ser saudável" constituem referências com múltiplos significados contextualmente muito diferentes.

Exemplarmente, partindo da afirmaçáo de uma "capacidade de ser saudável", dentro da abordagem das "capacidades"-capabilities proposta por Martha Nussbaum e Amartya Sen, e por influência ainda da especificação introduzida por Sridhar Venkatapuram, Brigit Toebes acentua a significação da saúde como uma necessidade vital, exigindo decisivamente protecção por parte do direito internacional. Afastando-se, então, da definição de "saúde" proposta pela Organização Mundial de Saúde, visando um sentido mais abrangente, acentua que garantir o acesso aos serviços de saúde não basta, será necessário o estabelecimento de condiçôes básicas propiciadoras de saúde - tais como acesso a água potável e saneamento, a informação e educação relacionadas à saúde, a condiçôes de trabalho seguras e saudáveis, e a ambientes de vida saudáveis $^{20}$. Efectivar tal "capacidade" como um "direito" implicará, assim,

17 Artigos $2 .^{\circ}, 3 .^{\circ}, 18 .^{\circ}$ a $21 .^{\circ}, 26 .^{\circ}, 28 .^{\circ}$ a $30 .^{\circ}$ da Declaração Universal dos Direitos Humanos.

18 Artigos 3. ${ }^{\circ}, 22 . .^{\circ}, 25 .^{\circ}$ da Declaraçáo Universal dos Direitos Humanos.

19 Preamble to the Constitution of the World Health Organization, 22 July 1946 (entry into force 7 April 1948).

20 «All in all, health is a vital need that requires strong protection under international law. For international health law, it would be important to focus on the individual's capacity to function adequately in society and to pursue one's life plans. Moving away from the absolute WHO definition prevents persons with chronic diseases or disabilities from being labeled as 'unhealthy'. It also implies that emphasis needs to be placed not only on ensuring access to healthcare services, but also on creating condi- 
envolver as instituições internacionais na sua estruturação e consubstanciação: se o "direito a ser saudável" é um direito humano enquanto interesse individual urgente - o direito "ao mais alto padrão de saúde possível”, ou o "direito à saúde" -, não é menos uma necessidade coletiva urgente, e simultaneamente indissociável do circunstancial desenvolvimento social e económico. É assim também o sentido amplo de saúde que está fundamentalmente em questão também na crise pandémica de COVID-19 21 , a acentuar as fragilidades de promoção e de protecção de direitos humanos em todos os continentes.

\subsection{Liberdade e segurança}

Reflectindo criticamente do ponto de vista jurídico sobre a liberdade e a segurança neste circunstancialismo, cumpre desde logo precisar os sentidos axiológico-normativos dos princípios da liberdade e da segurança enquanto fundamentos da juridicidade vigente, e a constitutivamente pertinente tensão dialéctica, primeiramente enquanto fundamentos da juridicidade vigente, e, assim, enquanto efectivos princípios normativos $^{22}$.

tions for being healthy, including access to safe drinking water and sanitation, health-related information and education, safe and healthy working conditions, and healthy living environments». - Brigit Toebes, "International Health Law: An Emerging Field of Public International Law”, p. 304 (vide p. 303-304), referindo-se a Amartya SEN, Development as Freedom, Oxford, OUP, 1999; Martha Nussbaum, Creating Capabilities: The Human Development Approach, Cambridge, Harvard University Press, 2011; Sridhar Venkatapuram, Health Justice: An Argument for the Capabilities Approach Cambridge/Malden, Polity Press, 2011.

21 Brigit Toebes, "International Health Law: An Emerging Field of Public International Law”, p. 304.

22 Vide, especialmente, António Castanheira Neves, "A unidade do sistema jurídico: o seu problema e o seu sentido", in Digesta - Escritos acerca do Direito, do pensamento jurídico, da sua metodologia e outros, vol. II, Coimbra, Coimbra Editora, 1995, p. 95-180, 172-175; Fernando José Bronze, Liçôes de Introdução ao Direito, Coimbra

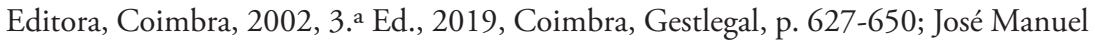
Aroso Linhares, "Na 'coroa de fumo' da teoria dos princípios: poderá um tratamento dos princípios como normas servir-nos de guia?”, in Fernando Alves Correia, Jónatas E. M. Machado, João Carlos Loureiro, Estudos em Homenagem ao Professor Doutor José Joaquim Gomes Canotilho, STVDIA IVRIDICA, 106, Ad Honorem - 6, Volume III Direitos e interconstitucionalidade: entre dignidade e cosmopolitismo, Coimbra, Coimbra Editora, 2012, 395-421, 413-421; José Manuel Aroso Linhares, "Validade comunitária e contextos de realização. Anotaçôes em espelho sobre a concepção jurisprudencialista 
A delimitação recíproca de princípios e de direitos fundamentais, nomeadamente da liberdade e da responsabilidade, aqui em questáo, póe, assim, um problema de adequação prático-normativa, especificamente de concordância prática ${ }^{23}$. Entre virtudes éticas, de um lado, e direitos e deveres jurídicos, do outro, longe de qualquer unanimidade, a dialéctica entre liberdade e responsabilidade implica que a fronteira entre o eu e o outro, e, assim, entre a liberdade e a responsabilidade, que do direito são específicas qualidades - a exigibilidade recíproca, ao outro e ao eu... -, assumam contornos contraditórios, consoante os contextos, dos mais individualmente reponsabilizantes aos mais colectivamente repressivos.

A liberdade, enquanto manifestaçáo de autonomia, categoria socialmente cunhada, constitui uma referenciação racional da acção, a que corresponde, na acepção da bilateralidade do direito, uma dimensão correspectivamente intrínseca de responsabilidade ${ }^{24}$... Ao lado desta, a segurança constitui igualmente um valor fundamental, conjugando-se numa compreensão materialmente densificante do direito compatibilizada com um sentido material, contextualizado, de justiça. Assumindo-se, então, a montante, como integrantes do conjunto dos princípios fundantes do direito, a liberdade a segurança náo serão menos, a jusante, efeitos da juridicidade vigente, enquanto consequências práticas da índole e efectivação do direito. E a produzir efeitos sustentados naquelas pressuposiçóes fundamentais - construindo e manifestando-se enquanto liberdade positiva e enquanto liberdade negativa, por um lado, e segurança, do direito, através do direito e perante o direito, por outro $^{25}$.

do sistema”, 2009, in Revista da Faculdade de Direito da Universidade Lusófona do Porto, 1/1, 2012, 30-35 (https://revistas.ulusofona.pt/index.php/rfdulp/article/view/2966).

23 Vide José Joaquim Gomes Canotilno, Direito Constitucional e Teoria da Constituição, 7. ${ }^{a}$ Ed., Coimbra, Almedina, 2003, p. 1161-1162, 1225.

24 Vide a reflexão apresentada em Ana Margarida GaudÊnCIo, "Responsabilidade como princípio e limite(s) da(s) intersubjectividade(s) jurídica(s): reflexóes em torno da proposta de Castanheira Neves", Revista de Direito da Responsabilidade, Ano 2, 2020, p. 771-790 (https://revistadireitoresponsabilidade.pt/2020/responsabilidade-como-principio-e-limites-das-intersubjectividades-juridicas-reflexoes-em-torno-da-proposta-de-castanheira-neves-ana-gaudencio/).

25 António Castanheira Neves, "Justiça e Direito", in Digesta - Escritos acerca do Direito, do pensamento jurídico, da sua metodologia e outros, vol. I, Coimbra, Coimbra Editora, 1995, p. 241-286. 
$\mathrm{Na}$ actual conjuntura de pandemia, as divergências em torno da tensão entre necessidade de confinamento e liberdade de circulação têm conduzido a discussóes sobre os (des)equilíbrios da(s) intersubjectividade(s), nomeadamente ao nível da relação entre liberdade e responsabilidade, e, mais do que isso, do sentido de corresponsabilidade. Trata-se, exemplarmente, de compreender a índole, os fundamentos e os critérios da determinação de confinamento face à liberdade de circulação, por um lado, e do confronto entre a procura de informação e as necessidades de fornecimento de bens e serviços face às exigências de tutela de direitos de privacidade e de protecção de dados pessoais, por outro ${ }^{26}$. Como se entre modelos de auto-responsabilizaçáo e modelos de hetero-responsabilização se escavasse um fosso intransponível, entre consideração e desconsideração da capacidade de autodisciplina e autonomia, e, assim, autodiscrição e autocontrolo... e, no que ao direito importa, entre (in)capacidade de autodefinição e auto-imposição de limites.

\section{Consubstanciação dos direitos humanos no/como dirreito, para lá da crise pandémica}

A mobilização do "discurso" dos direitos humanos como definição de uma condição humana ideal, determinada como universal, no enquadramento da actual crise pandémica, assume um papel crucial para a tomada de consciência das diferentes abordagens culturais e jurídicas das relaçóes entre as condiçôes de vida humana e as estratégias de expansão política e económica ${ }^{27}$. O que, sendo cada vez mais evidente perante a esta crise sanitária e humanitária global, se associa a múltiplas outras crises, que, entretanto, não se dissiparam, e vêm mesmo a agudizar-se - expondo, de um ou de outro modo, vulnerabilidades, mais ou menos graves, em todos os continentes, associadas a crises sociais, políticas e económicas, e consequentemente, a crises humanitárias, muito além do enfrentamento da pandemia de COVID-19 $9^{28}$.

26 Mart Susi (Ed.), Human Rights, Digital Society and the Law. A Research Companion, Routledge 2019; Council of Europe (Ed.), Human Rights Challenges in the Digital Age: Judicial Perspectives, 2020.

27 James R. MAY/Erin Daly, "Dignity Rights for a pandemic”, p. 6-7.

28 São neste ponto igualmente fundamentais as contínuas actualizações proporcionadas pelos relatórios da Human Rights Watch (https://www.hrw.org/). 
Projectar, neste e para além deste enquadramento, a realização dos direitos humanos como direitos, efectivamente jurídicos, vertendo em efectividade normativa as pressuposiçóes axiológico-normativas que encerram, implicará mais do que ver neles exigências de tutela dos cidadãos perante os Estados, e mesmo níveis diferenciados de protecção e/ou intervenção por parte dos Estados, em movimento potencialmente universalizável. Implicará determiná-los histórico-culturalmente e perspectivá-los a partir da contextualização específica da intersubjectividade jurídica. $\mathrm{O}$ que aqui se propóe essencialmente a partir da proposta de Castanheira Neves, ao afirmar a juridicidade dos direitos humanos para lá das construçóes que os projectam em pretensôes justificadas essencialmente por reivindicaçôes políticas, exactamente através da acentuação daquilo que tal nota de juridicidade lhes introduz de decisivamente diferenciador: o facto de, assumindo índole jurídica, implicarem, na consideração do outro, o contrapólo do dever, e, assim, afirmaçáo de direitos e titularidade de (correspectivos) deveres, numa comunitariamente assimilada dialéctica entre autonomia e responsabilidade ${ }^{29}$ - com o que a mencionada contextualização cultural da intersubjectividade jurídica conduzirá a diferentes equilíbrios, pressupondo a base dialógica da construção da juridicidade. Numa abertura do sentido do direito, na conjugação dialéctica entre o suum de cada um e um commune integrativo, como condição simultaneamente de delimitação recíproca de actuação e de convergência de realização do bumano ${ }^{30}$.

29 Vide António Castanheira Neves, "Uma reconstituição do sentido do direito na sua autonomia, nos seus limites, nas suas alternativas", 2009, in Revista da Faculdade de Direito da Universidade Lusófona do Porto, vol. 1, n. ${ }^{\circ}$ 1, 2012 (http://revistas.ulusofona.pt/index.php/rfdulp/issue/current/showToc, p. 20-21); António CAstanHeIra Neves, "O direito interrogado pelo tempo presente na perspectiva do futuro", in António Avelâs Nunes/Jacinto de Miranda Coutinho (Coord.), O Direito e o Futuro. O Futuro do Direito, Coimbra, Almedina, 2008, p. 9-82, p. 42-51.

30 António Castanheira Neves, Curso de Introdução ao Estudo do Direito: liçóes proferidas a um curso do $1 .{ }^{\circ}$ ano da Faculdade de Direito de Coimbra, no ano lectivo de 1971-72, Coimbra, 1971-1972, p. 125-130; António Castanheira Neves, "O princípio da legalidade criminal. O seu problema jurídico e o seu critério dogmático”, in Digesta - Escritos acerca do Direito, do pensamento jurídico, da sua metodologia e outros, vol. I, Coimbra, Coimbra Editora, 1995, p. 349-473, p. 416. Vide a reflexão já proposta em Ana Margarida GaudÊnCIO, "Responsabilidade como princípio e limite(s) $\mathrm{da}(s)$ intersubjectividade(s) jurídica(s): reflexóes em torno da proposta de Castanheira Neves", p. 4 ss. 
Propondo uma reflexáo sobre o sentido do direito que admita uma fundamentaçáo material da juridicidade dos direitos humanos e o reconhecimento de um núcleo, ou patamar, mínimo de valores comuns - neste ponto em aproximação à proposta de Mário Reis Marques ${ }^{31}$-, aponta-se a possibilidade, para lá de um primeiro patamar, mínimo, enquanto minimo comum de subjectividade universalizável, de uma multiplicidade periférica de substancializaçóes, não coincidentes, antes de densidade variável, consoante os contextos e bens-direitos-pretensóes em causa, e assim potenciando uma protecção em níveis diferenciados. Confronta-se, pois, essencialmente, uma intersubjectividade específica culturalmente subjacente à percepção de direitos humanos, aqui em causa, e, sobretudo, atentando na alteridade do Outro, que, agora com inspiraçấo em Douzinas - e, com este, em Levinas ${ }^{32}$-, faculte uma confrontaçáo inter-subjectiva racionalmente erigida a partir de uma dimensão (neste sentido, ética) de responsabilidade, susceptível de convocar para a respectiva fundamentação conteúdos de específica determinação cultural ${ }^{33}$.

Ainda que a dignidade humana seja um significante com tantos significados(-conteúdos) quantas as experiências civilizacionais consideradas - posto que a genérica categoria dignidade humana só fará sentido se substancialmente densificada, em concreto ${ }^{34}-$, só o reconhecimento

31 Mário Reis Marques, Introdução ao Direito I, p. 227. Vide idem, p. 227-242.

32 Vide Emmanuel Levinas, "Interdit de la représentation et 'droits de l'homme", in Emmanuel Levinas, Altérité et transcendance, Montpellier, Fata Morgana, 1995 (Le Livre de Poche, 2010), p. 127-135; Emmanuel Levinas, "Les droits de l'autre homme", ibidem, 149-153; Emmanuel Levinas, "Droits de l'homme et bonne volonté", in Emmanuel Levinas, Entre nous. Essais sur le penser à l'autre, Paris, Grasset, 1991 (Le Livre de Poche, 2010), p. 215-219.

33 Vide Costas Douzinas, The End of Human Rights, Oxford, Portland, Hart, 2000, especialmente 13. "The Human Rights of the Other", p. 343-369, especialmente p. 348-351 e 14. "The End of Human Rights", p. 371-380. Vide ainda os desenvolvimentos já propostos in Costas DouzInAs/Ronnie WARrIngton, Justice miscarried. Ethics and Aesthetics in Law, Hemel Hempstead, Harvester Wheatsheaf, 1994, sobretudo p. 80, e ibidem n. 183, p. 84, e ibidem, n. 200, p. 85, e ibidem, n. 201.

34 «(...) o princípio da dignidade (...) impóe-se como um verdadeiro prius axiomático, como um pressuposto irredutível, indefinível e até indizível do sistema jurídico. Dada a abrangência, a indeterminação e potencial evolutivo que o caracterizam, ele perfila-se como a referência mais elevada deste sistema e o seu princípio mais universal». - Mário Reis MArques, "A dignidade humana como prius axiomático", in Manuel da Costa Andrade/Maria João Antunes/Susana Aires de Sousa (Org.), Estudos em Homenagem ao Prof. Doutor Jorge de Figueiredo Dias, vol. IV, Coimbra, Coimbra Editora, 2009, 541-566, 566. 
reciproco dessa dignidade - compreendido como elemento constitutivo da subjectividade e da intersubjectividade jurídicas, e da respectiva efectivação - poderá constituir, dizendo com Castanheira Neves, o sustentáculo de um sentido materialmente autónomo do direito ${ }^{35}$, que, não se demitindo de afirmar uma validade - e não esquecendo os contributos de outras dimensóes práticas normativamente relevantes -, lhe confere a posição de indispensável instância ao mesmo tempo normativamente reguladora e reflexivamente crítica da praxis social.

Para lá da excepcionalidade da situação que vivemos, haverá uma sociedade pós-pandémica - permanecerá o afirmado novo normal? Que papel desempenharáo no dito novo normal a liberdade e a segurança, e, na sua sequência, a responsabilidade e a justiça? Os meios científicos prometem um regresso... Em tal profetizado regresso, que máscara será afivelada? Uma máscara que, por agora, se afigura também cada vez mais como manifestação de responsabilidade e de solidariedade - mais ainda, de cuidado... - em relação a si próprio e ao(s) outro(s)... $\mathrm{Ou}$ uma máscara como meio de afirmação de um individualismo protector, de isolamento e sectorização social, como outras já conhecidas, numa redução, senão mesmo substituição, da convivência, admitindo uma asséptica coexistência, esta mesma ainda em nome de uma selectiva protecção de certos sentidos de liberdade e de segurança...

Entre as pandemias dos factos, dos discursos, do medo, e a normatividade jurídica, apontam-se desafios decisivos, de uma eventual reconstrução dos conteúdos e das fronteiras da intersubjectividade. E, consequentemente, das reflexôes sobre o sentido e sobre a efectivação dos direitos humanos como direito(s).

35 Vide António Castanheira Neves, "Coordenadas de uma reflexão sobre o problema universal do Direito - ou as condiçôes da emergência do Direito como Direito", in R. M. Moura Ramos, C. Ferreira de Almeida, A. Marques dos Santos, P. Pais de Vasconcelos, L. Lima Pinheiro, M. Helena Brito, D. Moura Vicente (Org.), Estudos em homenagem à Professora Doutora Isabel de Magalhães Collaço, vol. II, Coimbra, Almedina, 2002, p. 837-871, p. 869-870. 



\section{DIREITO CONSTITUCIONAL E PANDEMIA: RESPONSABILIDADE PELA JUSTIÇA SOCIAL E NECESSIDADE(S) DE SAÚDE PÚBLICA}

Luís Meneses do VALE

\section{Intro dução}

Depois da exposição aos valores respigados pela sondagem especificamente bioética da pandemia e após a consideração dos direitos humanos, em cujo discurso se cruzam hoje vultosas problematizaçóes axiológicas de índole política, jurídica e moral, cabe agora ${ }^{1}$ atentar na constitucionalidade responsável por assumi-los e reflecti-los - crítica, constitutiva e fundamental-regulativamente - no (e desde o) projecto normativo-político global por que as comunidades políticas historicamente se auto-transcendem, segundo a intencionalidade específica dessa indagação por um certo nomos - do, pelo e para o - comum,

Ora, como a presente investigaçáo questione directamente a valia e capacidade prestacional exibida e prometida pelo direito e a política na resposta ao desafio colocado pela actual pandemia e a forte probabilidade de similares emergências no futuro próximo, impóe-se asseverar, logo à cabeça, o lugar e papel fundamental das constituições na nossa comum responsabilidade pela justiça - social, jurídica, da saúde pública e dos cuidados de saúde: tanto na qualidade de Grundnorm do ordenamento legalmente positivado, como na de projecto cultural de ordenação e convivência sócio-política.

1 Descansando largamente no tratamento dogmático de que a tutela jurídico-pública (constitucional e administrativa) da saúde será objecto no próximo capítulo, para ensaiar um volteio mais teórico, de lances forçosamente imprecisos (que deferem pormenores para uma possível versão mais extensa e pormenorizada, a trazer à luz noutra instância). 
Se bem se vê, uma aturada análise jurídica do regime de necessidade ditado pela pandemia arriscar-se-ia seriamente a desviar-nos do propósito precípuo da investigação desenvolvida: menos assestada à auto-reflexão e auto-regulação do direito e da constituição, perturbados por esta ou outra situação emergencial, do que à crítica reflexão das funçôes sociais pelas quais procuram prevenir, precatar e combater semelhantes vicissitudes. Com efeito, mesmo no plano menos substancial do ordenamento, a garantia secundária de auto-subsistência constitui apenas uma parte da resposta jurídica e constitucional reclamada pelas circunstâncias, cedendo, neste escorço, à função primária e ao seu significado material relativamente à sociedade. Nada que haja de embotar a relação com as normas secundárias, terciárias (ou até quaternárias), sobretudo se densificadas por uma intelecção fenomenológica do modo-de-ser do direito e da normatividade constitucional (enquanto princípio de 'estrutura-ação): v.g., quanto ao momento sociológico-material das fontes, à realidade jurídica no seio do sistema, à eficácia e efectividade de que depende a respectiva vigência, e, sobretudo, à especifica racionalidade e método da sua praxis de realização. Na verdade, também indirectamente - enquanto lei básica ou suprema, lei das leis e fonte politica das fontes - ela acaba interpelada na sobredita tarefa de fundamental e estruturante conformaçáo normativo-material da sociedade (com toda a sua pluralidade de interesses, poderes e valores, e as práticas, instituiçôes e subsistemas societais que engendram e sustentam).

Omitindo explicitaçóes certamente devidas, mas aqui incabíveis, vale dizer que a constitucionalidade se intenciona, nesta sede, como dimensão quase ecológica ou eco-sistémica da nossa habitação social no mundo, enquanto sentido de valor subjacente ao design, arquitectura e dinâmica das instituiçóes justas, na complexa mediação entre o bem e a correç̧ão ou rectidão, pelas quais, participativamente, procuramos e cultivamos, em contexto de pluralidade, as possibilidades do comum; ou seja, que por essa esquiva justiça visam a paz, buscam a auto-correcção estabilizadora da estrutura social básica ou ensejam co-mover-nos à pro-moção da socialidade democrática e normativa indispensável à integração social. Daí que, não obstante os escrúpulos protestados, cumpra apurar se, e em que medida, ela logrará eximir-se às impugnaçóes compreensivelmente lavradas contra a tentaçáo tecnológico-social, de inspiração biopolítica, cujas técnicas de governamentalidade e disciplinaridade, através da metanóia individual e do governo dos corpos, a situação 
de emergência, o estado de excepção e o direito de necessidade, longe de transtornarem ou surpreenderem, apenas intensificariam, afinal ${ }^{2}$.

Desta feita, nas páginas que se seguem (I) proceder-se-á, primeiro, do ethos para o nomos, e dialecticamente entre ambos, a propósito da responsabilidade e do recíproco condicionamento e efectivação entre justiça e saúde que a teleonomologia constitucional pretende sancionar positivamente; (II) confrontar-se-á, depois, essa constitucionalidade socialmente responsável pela justiça e pela saúde com os limites e limitaçóes impostos e revelados pela ananké pandémica e a fractura tragicamente dilemática entre salus populi e suprema lex que nos faz sofrer, iluminando, tenuemente, os quadros teórico e dogmático (internacional e nacional) pertinentes. A essa luz se ensaiará (III) uma sumária crónica da resposta portuguesa à crise, reconstituindo racional-narrativamente os acontecimentos padecidos, com menção dos seus protagonistas, principais capítulos, episódios cruciais e assuntos recorrentes. Para concluir (IV), muito modestamente, com algumas liçóes sobre o passado e o presente e, quiçá, algumas sugestóes para o futuro, animadas pela confiança constitucional e a síntese de responsabilidade e esperança (P. Häberle) que por ela nos propomos redimir (J. Balkin).

Ao percurso, assim prefigurado, deverá prepor-se um último conjunto de explicitaçóes quanto à situação de partida e às falsas evidências com que pode facilmente trair-nos. Desde logo, e no imediato seguimento do exposto, a muito cauta expectativa em relação ao rol de ensinamentos possivelmente recolhidos nasce, não só de metodológica prudência histórico-filosófica quanto à alardeada magistralidade do passado, como também de uma dúvida concreta relativamente à natureza e jaez da experiência proporcionada pelo difícil período que atravessamos; nomeadamente, no que toca ao valor de prova e provaçâo que se lhe tem assinado, à laia de pretenso momento de verdade e moralizante ou propedêutico (se não terapêutico) castigo e sacrifício. Afinal

2 V. Günther Frankenberg, Staatstechnik: Perspektiven auf Rechtsstaat und Ausnahmezustand, Berlin: SuhrkampVerlag, 2010. A propósito da actual pandemia, v. Ming-Sung Kuo, "From Institutional Sovereignty to Constitutional Mindset: Rethinking the Domestication of the State of Exception in the Age of Normalization", in Richard Albert/Yaniv Roznai (Eds.), Constitutionalism under Extreme Conditions: Law, Emergency, Exception, Springer, 2020, pp. 21-39; e Pedro A. Villarreal, "Public Health Emergencies and Constitutionalism Before COVID-19: Between the National and the International", Ibidem, pp. 217-238. 
de contas, não se revela ele, também (ou sobretudo...), atreito à manipulação e difusão de falsidades, a ilusórias imagéticas, aos engodos e distorçôes perceptivas e mesmo a perversas sublimaçóes segregadas pelo nosso inconsciente? Parece longe de seguro, em todo o caso, que se nos ofereça como inequívoco factor de nitidez, que não de adumbramento, em matéria de auto-representação e autoideação individual e colectiva enquanto seres aí, no mundo e entre os outros.

As ambiguidades prolongam-se, etimologicamente, na oscilação conceitual entre excepção, necessidade e emergência, mesmo que alijemos, da sua pesada carga histórica e jurídico-dogmática, os termos empregues: (i) o primeiro, a expôr as insuficiências da lógica referência à regra, admitindo o potencial libertador da fuga ou escape, em contraste com a conotação negativa da expunção ou extracção de um conjunto ${ }^{3}$; (ii) a categoria alética, traduzida pelo segundo, a minar as condições da liberdade empírica ou transcendental e do sollen deôntico sobre elas erguido, abre a ferida nunca totalmente suturada de todas as monísticas (ou quando menos dialécticas) normativizaçóes das necessidades sociais; (iii) o terceiro, a diluir-se no genérico fluir dos acontecimentos contingentes, assomados como indomesticáveis e-ventos, ou então, na emergencialidade da vida (desde a filogénese, à ontogénese e à noogénese) e dos padróes culturais evolucionariamente gerados pela complexificação social.

Por fim, entre a luz e a sombra, a regra e a excepção, o necessário e o devido, haveria de esclarecer-se, fosse outro o fôlego, como encarar a diferença especifica do tempo que agora nos calhou, relacionando analogicamente o velho com o novo, numa inevitável reflexão crítico-reconstrutiva do próprio tertium pressuponendo (F. J. Bronze) pela racionalização da humana temporalidade histórica, em que se inscrevem as constituiçóes, enquanto respostas colectivas - de, para, por e perante algo e alguém.

Repudiando o novismo fascinado, tanto como o relativismo de um nibil novum sub sole (que absorve toda a surpresa na indiferença), deverão equacionar-se seja (i) o património que o general intellect acumulou em matéria de pandemias, seja (ii) o pecúlio histórico e reflexivo do direito constitucional, relativamente às situaçôes de emergência, neces-

3 De que norma-lidade ou norma-tividade - e com que sentido (emancipação, exclusão ou a-bandono) - sairíamos, e para onde (de qual dentro e para que fora)? 
sidade ou excepção, sem com isso menoscabar o kairós que a actual crise proporciona para uma crítica profunda da sociedade e a invençâo/ descoberta de critérios para a sua transformação.

Quanto à primeira (concorrendo embora também para a substanciação da segunda), basta recordar a sucessão de crises que vimos enfrentando - desde a irrupçáo do novo terrorismo, após o 11 de Setembro, passando pela débacle económico-financeira, em 2007, até à multiplicação de catástrofes naturais (tufôes, incêndios, cheias) e ao cúmulo de antecedentes pandémicos (a SARS, Gripe Aviária, Ébola, Zika) - e a acuidade que, em consequência, confere à agenda da preparabilidade e resposta ${ }^{4}$. No que concerne à segunda, conviria - antes de tudo - náo desprezar as mudanças que fenómenos relativamente semelhantes provocaram ao longo dos tempos ${ }^{5}$, e a exortaçáo que nos lançam, enquanto promessas incumpridas, muitas aspiraçôes e anseios nascidos desses episódios catástróficos ou do lento e pervasivo acúmulo de injustiças que, em escandalosa prorrupção, subitamente revelam ou sintomatizam.

4 Note-se que a OMS dedicou o relatório mundial de 2007 à segurança sanitária e propôs-se devotar ao lema da preparaçáo e resposta o ano de 2019, no âmbito de um plano quinquenal iniciado em 2018 - v. WHO, The World Health Report 2007: Global Public Health Security in the 21st Century, WHO, Geneva, 2007o Relatório do Director Geral, Public health emergencies: preparedness and response, Annual report on the implementation of the International Health Regulations (2005): Progress in the implementation of the five-year global strategic plan to improve public health preparedness and response (2018-2023), WHO, 2019. Não obstante, cfr. as observaçóes tecidas em 2017 por Andrew LAKOFF, na análise essencialmente teórica que desenvolve no seu: Unprepared. Global Emergency in a Time of Emergency, University of California Press, 2017. Aí se perspectivam e delineiam, aliás, dois modelos distintos de resposta às emergências: um baseado no cálculo do risco e num imperativo de precaução e outro assente na ideia de preparabilidade ou preparação potencial (preparedness). Ademais das alusóes feitas na candidatura do projecto vertente, v., mormente para dilucidaçóes terminológicas ocorrentes, Bruce Jennings/John D. Arras/Drue H. Barrett/Barbara A. Ellis (Eds.), Emergency Ethics. Public Health Preparedness and Response, Oxford University Press, Oxford, 2016; Chloe Sellwood/Andy Wapling (Eds.), Health Emergency Preparedness and Response, Cabi, Wallingford, Boston, 2016; Rebecca Katz/ James Banaski (Eds.), Essentials of Public Health Preparedness and Emergency Management, 2nd Edition, Jones \& Bartlett, Wall Street, 2019.

5 V., por todos, Walter Scheidel, The Great Leveler: Violence and the History of Inequality from the Stone Age to the Twenty-First Century, Princeton University Press, Princeton, 2017; Jared Diamond, Collapse: How Societies Choose to Fail or Survive, Penguin Books, London, 2005. 


\section{Responsabilidade e Constitucionalidade: entre Ethos e Nomos}

\section{Responsabilidade}

Apesar de seminal no universo das nossas referências normativas, a responsabilidade retiniu tardiamente na reflexão filosófica e - mais ainda - nas suas peculiares terminações políticas e sociais. Por sobre isso, a centralidade que se the reconhece no mundo jurídico e no discurso moral, de onde foi exportada recentemente para aquelas esferas, ameaça toldar-lhe o sentido, eminentemente prospectivo e positivo, institucional e estrutural ${ }^{6}$, com que aí se manifesta. Efectivamente, a afirmação de

6 Além de Hans Jonas e Karl Otto-Apel - lídimos percursores desta viragem na (ou para a) responsabilidade (e entre nós trazidos ao regaço do direito constitucional nas exaustivas e exemplares reflexóes como sempre desenvolvidas pelo Senhor Doutor João Loureiro), tem-se em vista a responsabilidade estrutural (pela conexão social) de Iris Marion Young, a responsabilidade institucional positiva de Yasha Monk, ou até o esquema de responsabilizaçáo pelo dano, assente em deveres negativos, de Thomas Pogge - v. Iris Marion Young, Responsibility for Justice, Oxford University Press, Oxford, New York, 2011; Yasha Monk, The Age of Responsibility. Luck, Choice, and the Welfare State, Harvard University Press, Cambridge (Ma), London, 2017; Thomas Pogge, World Poverty and Human Rights: Cosmopolitan Responsibilities and Reforms, 2nd ed., i.a. Polity Press, Cambridge, 2008. Louvando-se do contributo de Young (posta em diálogo com Derek Parfit, Christopher Kutz, Judith Lichtemberg, Mary Gray, Melissa Lane, Barbara Fried), cf Vafa Ghazavi, "Ethics at a distance", in The Politics of Care. From Covid 19 to Black Lifes Matter, Review \& Verso Books: Boston, 2020; Kathryn Siknink, "Rights and responsibilities in the Coronavirus pandemic", Open Global Rights, 30 March 2020 (texto que se reivindica também, muito sugestivamente, da Verantwortungsethik de Max Weber). Não se ignoram as dificuldades colocadas por estas transfiguraçóes da responsabilidade, nem as diferenças que as separam da tradicional configuração da responsabilidade jurídica, sobretudo atenta a estrita delimitação quoad modum e quoad substantiam que a matriz intersubjectiva desta última assegura. Todavia, torna-se impossível explanar nesta sede os notáveis esforços de consolidação do potêncial detectado e já libertado pelo eidos-ousia deste Oberbegriff da razão prática - cf., na expectativa de desenvolvimentos ulteriores, em ocasiáo mais propícia - Kurt BAYERTZ/ Birgit Beck, "Soziale Verantwortung Zur Entwicklung des Begriffs im 19. und frühen 20. Jahrhundert". Preprints and Working Papers of the Centre for Advanced Study in Bioethics Münster, 81, Westfälische Wilhelms-Universitäts, Münster, 2015; explorando as inúmeras declinaçóes possíveis da responsabilidade, Ludger HeIdbrink/Claus LaNGBeHN/Janina LoH (Hrsg.), Handbuch Verantwortung, Springer, Wiesbaden, 2017; Jan Henrik Klement, Verantwortung. Funktion und Legitimation eines Begriffs im Öffentlichen Recht, Mohr Siebeck, Tübingen, 2006; Joseph Raz, From Normativity to Responsibility, Oxford University Press, Oxford, 2012. 
uma responsabilidade pela justiça social, em geral, e pela saúde, em particular - para o que agora nos interessa - remete à radical recompreensão do Mit-Sein humano e da objectiva solidariedade a que o convocam as interdependências naturais, técnicas e culturais da socialidade assim hibridamente pressuposta, pela qual se rompe com a exclusiva e redutora circunscrição da categoria, dos ideários que sustenta e veicula e das repercussôes práticas que consequentemente irradia, à medular (e inabdicável, note-se!) imputação moral, repousada, em última instância, sobre a razão e a liberdade do sujeito transcendental, subjacente ao eu empírico e fenomenal.

Tal responsabilidade... responsabiliza-nos também pela constitucionalidade capaz de a honrar e pelo direito susceptível de lhe fazer jus, actualizando os valores-tarefas e as convicçóes-fins que a animam nas instituiçôes de uma cultura-ambiente favorável ao ethos correspondente e à responsividade micro, meso e macro em que se exprime a sua permanente abertura à alteridade e à estranheza. Gera-se, assim, uma cadeia de responsabilidades ${ }^{7}$ por um conjunto de bens, enleados, fáctica e normativamente (ou ôntica e axiologicamente), na dinâmica prática da respectiva realização.

De feito, a justiça social (inclusive de ambição global) enquanto exigência de realização estruturalmente integrada da igualiberdade pessoal ao longo das várias esferas societais, engendradas em torno do acesso aos principais bens colectivos, correlaciona-se, duplamente, enquanto factor e efeito, com a justa provisão de cuidados de saúde e a promoção e protecção da saúde pública, nas quais encontra duas das suas densas dimensões constitutivas ou expressivas ${ }^{8}$. Não há justiça social sem

7 Neil Levy, "Taking Responsibility for Responsibility", in Public Health Ethics, Volume 12, Number 2, 2019, pp. 103-113; John Coggon, "Legal, Moral and Political Determinants within the Social Determinants of Health:. Approaching Transdisciplinary Challenges through Intradisciplinary Reflection", Public Health Ethics, Volume 13, Issue 1, 2020, pp. 41-47.

8 Karien Stronks/Brigit Toebes/Aart Hendriks/Umar Ikram/Sridhar VenKaTAPURAN, Social justice and human rights as a framework for addressing social determinants of health. Final report of the Task group on Equity, Equality and Human Rights. Review of social determinants of health and the health divide in the WHO European Region, WHO Copenhagen, 2016; Richard Wilkinson/Michael Marmoт (Eds.) Social Determinantes of Health: The Solid Facts, $2^{\text {nd }}$ edition, WHO, Copenhagen, 2003. Sudhir Anand/Fabienne Peter/Amartya Sen (Eds.), Public Health, Ethics, and Equity, OUP, Oxford, 2004; CSDH, Closing the gap in a generation: health equity through action on the social determinants of health (Final Report of the Commission on 
saúde, nem saúde sem cuidados de saúde e políticas de saúde pública justas, do mesmo passo que estas, e aquela, beneficiam da justiça social e suas exigências e repercussões nos demais sectores.

Recobra assim legitimidade, numa espiral de correlaçóes inter-influentes, a responsabilidade infra-estrutural pela criação, manutenção e incremento de práticas e instituiçôes de atenção e resposta - equivale asserir, capacitadas para uma permanente atentividade, atendimento e responsividade, tanto às imediatas solicitaçôes e necessidades das pessoas, como aos múltiplos planos de expectativas fácticas e normativas que acalentam, e pelos quais legitimamente se movem, em relação a quaisquer ocorrências pessoais, de magnitude colectiva e até internacionais ${ }^{9}$.

\section{A constitucionalidade}

$\mathrm{Na}$ acepção, simultaneamente mais lata e mais estrita, para que nos remetem os estudos constitucionais e a moralidade politica de uns, bem como a jurisprudência e direito politicos ou a cultura e software constitucional, propugnados por outros, surpreendemos aqui a constitucionalidade na tripla encruzilhada (i) entre o nacional e o internacional, (ii) a normalidade e a normatividade (iii) o direito, a política e as arenas sociais.

No primeiro caso, à guisa de uma interconstitucionalidade construída como aspiração de inter e transculturalidade, a partir de subjectividades, práticas, instituiçóes, sistemas, e intençôes trans-estaduais; no segundo, como resposta sócio cultural (de cultura/nomos político-social) ao problema clássico da integração e ao risco de Zerfall (adorniana), contra o fatalismo do oráculo böckenfordiano e em detrimento, repita-se, dos modelos normativo-formal de Kelsen, estadual ou ordenamental-material de Schmitt e científico-espiritual de Smend; finalmente, a título de meta-medial trans-estrutur-ação ou trans-institucionaliz-ação integradora do pluralismo e diferenciação societais, numa molecularidade escalar (do nível regional ou local ao global), em torno da cronotópica

Social Determinants of Health), World Health Organization, Geneva, 2008; Daniel S. Goldberg, Public Health Ethics and the Social Determinantes of Health, Springer, Cham, 2017;

9 Sobre a responsividade, v. Luís Meneses do VALE, "Responsividade nos sistemas públicos de saúde: o exemplo da OMS", in Estudos de Homenagem ao Professor Doutor Figueiredo Dias, Volume IV, Coimbra Editora, Coimbra, 2010, pp. 1049-1106. 
incorporação ou radicação carnal do homem e dos módulos estatutários (e correspectivos eco-sistemas) da sua igual liberdade de realização.

Enquanto, na primeira instância, atende à mundialização do fenómeno pandémico, e na segunda se abre às provocaçóes suscitadas pela disrupçáo do quotidiano e do seu quadro normativo ${ }^{10}$, na terceira, retomando as anteriores, esboça a específica integração normativo-constitucional e multinível, em contexto de diferenciação societal global, sobre-estruturando os sectores sociais, a partir de dentro, com base nos direitos e respectivas instituiçóes de suporte ${ }^{11}$. Até que ponto espera e responde, resiste e confronta, então, desde o seu núcleo central, os ingredientes da tragédia (Jack Balkin), é o que importará saber, a partir do caso da saúde.

\section{Responsabilidade constitucional pela justiça na saúde pública}

Tomando por boa a evidência aduzida quanto ao círculo virtuoso que a justiça e a saúde proporcionam, sempre que mutuamente reforçadas através de correctas e justas mediaçóes regulativas e sancionatórias, preconiza-se a correspondente responsabilidade constitucional (jurídica e política) pela respectiva garantia ${ }^{12}$.

10 Já que a normativização das necessidades sociais, associando o bem-estar colectivo a valores/bens reconhecidos, e a felicidade individual a uma ideia eudemónica, demulce a resistência contrafactual à emergência de situações ditas de necessidade, repondo - pela enésima vez - um dos grandes problemas da filosofia prática pós-kantiana e, bem assim da teoria e metodologia jurídicas e políticas contemporâneas. Dificuldade a que as vias procedimental ou conflitual (discursivas ou de inspiraçáo sistémico-funcionalmente autopoietica), por um lado, não alcançam vencer de modo totalmente convincente, e com que o jurisprudencialismo, por outro, custosamente se debate quando suspensa, no plano macro ou mesoscópico, de uma também político-social normatividade de teleológica modelação das acçôes e instituições complexas, - designadamente, através do sistema de atribuiçóes e competências de entidades públicas finalizadas à satisfação de interesses colectivos.

11 Chamando a atenção, com outra profundidade, alcance e entorno, para a trans- ou supra-estadualidade das questóes em apreço, e o consequente apelo à internormatividade, Joáo Loureiro, "Bens, Males e (E) (E)stados (In)constitucionais: Socialidade e Liberdade(s): Notas sobre uma Pandemia”, in Revista Estudos Institucionais, v. 6, n. 3, set./dez. 2020, pp. 787-832.

12 Sobre o direito da saúde pública, v. Lawrence Gostin (Ed.), Public Health Law and Ethics. A Reader, University of California Press, Berkeley, Los Angeles, London, 2002 e John Coggon/Keith Syrett/A.M. Viens, Public Health Law: Ethics, Governance and Regulation, Routledge, London and New York, 2017. 
Numa interpretação ampla dos blocos constitucionais e das redes transnacionais de que fazem parte os países lusófonos, avultam as responsabilidades internacionais defluentes dos sistemas universais e regionais, genéricos e sectoriais de direitos ${ }^{13}$, com destaque para as obrigações estatuídas no PIDESC ${ }^{14}$ e precisadas pela jurisprudência doutrinal do Comité dos Direitos Sociais, quer em matéria de aplicabilidade, eficácia, intensidade, ritmo e alcance, quer através da distinção material entre deveres de respeito, protecção e realização (facilitação, promoção e prestaçâo), ou mediante a especificação das inerentes garantias de sistemas de saúde disponiveis, acessiveis (geográfica, financeira, cognitiva e tempestivamente) e aceitáveis, quer ainda com relação à saúde pública e às determinantes sociais do bem-estar. Exigências que o Protocolo Facultativo tornou mais pregnantes, e os Altos Comissários e Relatores Especiais densificaram e determinaram com enorme coragem e frontalidade nos últimos anos.

A nível interno ${ }^{14}$, junta-se-lhes a adesão a um paradigma desenvolvimentista - precoce e precipitadamente desacreditado, como a história

13 V. Convenção Internacional sobre Eliminação de todas as Formas de Discriminação Racial (12º e 11.\%/1, Convenção sobre os Direitos da Criança (24. ${ }^{\circ}$ ), Convenção sobre os Direitos de Pessoas com Deficiência (25. $)$, Carta Social Europeia (11. e 13. ${ }^{\circ}$ ), Carta dos Direitos Fundamentais da UE (...), Convenção de Oviedo (art 3. ${ }^{\circ}$ ), Carta Africana dos Direitos do Homem e dos Povos (16.0); Carta Africana sobre o Bem Estar da Criança (14. ${ }^{\circ}$ ); Protocolo Adicional à Convenção Americana sobre Direitos Humanos em matéria de Direitos Econômicos, Sociais e Culturais (Protocolo de San Salvador), (art 10. ${ }^{\circ}$ ), entre outros...

14 V. art. 12. Cfr Luís Meneses do VAlE, "Sobre o sentido jurídico do acesso aos bens sociais fundamentais: a 'jurisprudência doutrinal' da ONU em matéria de saúde", e-cadernos CES, 15, 2012: 70-97; já no decurso e a respeito da pandemia, cf. Pedro A. Villarreal, "Can They Really do That? States' Obligations Under the International health regulations in Light of Covid 19" (Part I e II), in in Barrie SANDER/Jason Rudall (eds.), COVID-19 and International Law, Opinio Juris Symposium, March 30, 2020; Tim Fish Hodgson \& Ian Seiderman "COVID-19 Responses and State Obligations Concerning the Right to Health", Part I and II, Ibidem.

15 Descontados agora direitos correlacionados e os princípios fundamentais da constituição e do regime jussubjectivo (ou as tarefas gerais e as incumbências prioritárias do Estado na Economia), v. Constituição da República Portuguesa (art. 64. ${ }^{\circ}$ ), Constituição da República Brasileira (196. a $199 .^{\circ}$, além do art. 6.º); Constituiçáo da República de Angola (77. ${ }^{\circ}$, mas também 21. ${ }^{\circ}$ ); Constituição da República Moçambicana (89. ${ }^{\circ}$ e $1160^{\circ}$ ). Por su vez, segundo o Artigo $123 .^{\circ}$ da Lei Básica da Regiáo Administrativa Especial de Macau, o Governo Regional define, por si próprio, a politica respeitante à promoção dos serviços de medicina e saúde e ao desenvolvimento da medicina e farmacologia chinesas e ocidentais. As associaçóes sociais e os particulares podem prestar, nos termos da lei, serviços de medicina e saúde de qualquer tipo. Os Serviços de Saúde 
vem revelando ultimamente - que relaciona os direitos sociais com as políticas públicas ${ }^{16}$, nos moldes daquele constitucionalismo transformador comum, teorizado por A. Von Bogdandy, a propósito da América Latina. O que uns detractam como romantismo e idealismo aspiracional - assaz mal encarado no norte global (enquanto escusado bloqueio e complicação jurídicos, ingenuidade utopista ou pura compensação simbólica) mas partilhado com os países mediterrânicos - comparece nos princípios fundamentais e estruturantes, tarefas e incumbências do Estado, na garantia dos vários sectores de produção, na subordinação política da economia, na preocupação de interação e coesão social, e claro, na umbilical relação estabelecida entre os direitos sociais e as respectivas garantias institucionais de realização, mediante infra-estruturas democraticamente socializadoras como são os sistemas de saúde de tipo beveridgiano.

A distância entre norma e realidade, texto e acção, performance e impacto, percepção, apreciação e satisfação do público variam significativamente de Portugal para o Brasil, e deste para os países Africanos ${ }^{17}$, mas nem por isso se apequena o valor (intrínseco e consequencial) da opção constitucional por um modelo democrático-social (que não ape-

Públicos da RAE dependem da Secretaria dos Assuntos Sociais e Cultura e ocupam-se tanto da prestação de cuidados de saúde diferenciados e primários, bem como da execução das acçôes necessárias à prevenção da doença e à promoção da saúde (incluindo a vigilância epidemiológica, a educação para a saúde, a higiene alimentar, o controlo de vectores de higiene ambiental, a saúde ocupacional e a vigilância sanitária comunitária). Diga-se, por fim, que a actuaçáo das autoridade, durante a pandemia, se regeu, neste campo, pelas disposiçóes constantes da Lei n. ${ }^{\circ}$ 2/2004 (lei de prevenção, controlo e tratamento de doenças infeciosas), elaborada e aprovada na sequência da epidemia SARS, nos primeiros anos do actual milénio. Quanto à constituição da China, entre os Princípios Gerais estatui-se, no art. $21 .^{\circ}$, i.a., que o Estado, a fim de proteger a saúde das pessoas, deve desenvolver cuidados médicos e de saúde, assim como a medicina moderna e tradicional, encorajar e apoiar a gestão de várias infra-estruturas médicas e de saúde por organizaçôes económicas colectivas rurais, empresas públicas, instituiçóes públicas e organizações de vizinhança, e promover actividades de saúde pública. E no art. $45, \$ 1$, acrescenta-se que os cidadãos da república devem ter o direito a assistência material do Estado e da Sociedade quando forem idosos, estiverem doentes ou perderem a capacidade de trabalhar. $O$ Estado deve, pois, desenvolver a segurança social, a assistência social e os serviços médicos e de saúde necessários para os cidadãos gozarem deste direito.

16 Em Portugal e Angola nos vários números de um artigo, embora a afirmação de um direito resulte clara apenas no primeiro caso. Nos demais, em vários.

17 Sem falar no caso extremo de Macau. Tenha-se em vista, a título exemplificativo e aliás emblemático das duas culturas em causa, o contraste entre a escassa exploração da via judiciária em Angola e a judicialização acentuada no Brasil. 
nas assistencialista ou previdencial) de igualização (de todos para todos), alinhado ou sintonizado, de resto - seja quanto aos cuidados de saúde (graças à a universalidade, à generalidade ou compreensividade, e ao financiamento solidário), seja em relação a esses e outros factores determinantes da saúde colectiva, através do bem-estar - com os objectivos de desenvolvimento do milénio, a revolução ecológica ou ambiental-social no tocante aos determinantes de saúde e os melhores parâmetros, recomendaçóes e práticas internacionais nascidos das agendas da universalização, dos novos serviços públicos e comuns, dos sistemas integrados, da saúde global, das politicas orientadas para igualdade, etc.

Em suma, a preparação e responsividade às emergências de saúde avultarão numa sociedade: (i) solidariamente responsável, igualitária e coesa, onde a paz social e as possibilidades de realização são obras $d a$ justiça (que sedimenta a confiança interpessoal e institucional, contribuindo para a resiliência individual e colectiva); (ii) com políticas de saúde pública transversais aos vários sectores sociais e um sistema de saúde público justo, por legítimo e eficaz; (iii) dotada de capacidade para actuar de maneira integrada, com o respaldo dos cidadãos, combinando as políticas públicas globais com as sectoriais, reflectindo a saúde em todas elas e conjugando os vários planos de resposta do sistema de cuidados.

\section{Sob o Signo da Ananké: necessidade(s) de saúde}

\section{Aspectos geraiis ${ }^{17}$}

Quem se náo resigne ao escapismo formalista de um normativismo ideal e refuse capitular à soberania pré-jurídica de um poder mais ou

18 Como locus classicus sobre o tema, no século XX, v. obviamente, as obras de Carl Schmitt, sobretudo da década de 20, com realce, logo no início do decénio, para Die Diktatur. Von den Anfängen des modernen Souveränitätsgedankens bis zum proletarischen Klassenkampf, 1921 e Idem, Politische Theologie. Vier Kapitel zur Lehre von der Souveränität, 1922. Um resumo de fácil compreensão colhe-se em Elliot BuLMER, Emergency Powers, International IDEA Constitution-Building Primer 18, IDEA, Stockholm, 2018. Em termos eminentemente sociológicos, cf. Matthias LemKe, "What does state of exception mean? A definitional and analytical approach", Zeitschrift für Politikwissenschaft, 28, 2018, pp. 373-383; Idem (Hrsg.), Ausnahmezustand. Theoriegeschichte - Anwendungen - Perspektiven, Springer, Wiesbaden, 2017. Como testemunho muito próximo da heterogeneidade dos contributos disponíveis, v. as recentes 
menos teologizado, ou render-se à normativização de uma facticidade puramente contingente - trazendo antes, para o interior da normatividade, culturalmente inteligida e vivida, a tensão constitutiva entre axiológico-normativas exigências de ideal validade e prático-materiais instanciaçóes performativas da sua eficácia ou efectividade - depara, a propósito do instituto do direito ou estado de necessidade, emergência ou excepção, com uma verdadeira situação-limite, suspensa na ponte radbruchiana entre ser e valer, rasurada nas entrelinhas dos Schranken e Grenzen do direito e problematizadora dessas complexas dobras do existir, conhecer e avaliar humano que racionalmente gostaríamos de assegurar medial-dialecticamente produtivas e superiormente sintetizantes. Como se anunciou, o problema cresce em melindre se a jurisprudencialista superaçáo possível da dificuldade (mediante um juízo decisório culminante dessa espiral de correspondências, mutuamente afinadas, entre o sistema e a controvérsia jurídica, a problematicidade intencional da norma e a problemática do caso ${ }^{19}$ ) cede o passo a uma crítico-reflexivamente reconstitutiva relaçáo de amplo espectro entre normatividade e realidade social - como sucede no domínio, segundo a perspectiva e de acordo com a consciência intencional a que se abre o fenómeno da constitucionalidade.

A figura remonta aos primórdios da reflexão jurídico-política, designadamente no contexto da república romana (onde o ditador, nomeado pelas magistraturas superiores, era temporariamente investido dos poderes e símbolos de Imperium), tendo sido repensada por $\mathrm{Ma}-$ quiavel na transição para idade moderna, ou por Locke (teorizando os poderes de prerrogativa) e depois Rousseau e Harrington, já nos alvores da contemporaneidade, para explodir no dramatismo dos debates proporcionados pelo caldo cultural, político, económico e social em que se viu mergulhada a Republica alemã de Weimar. À conta sobretudo de Giorgio Agamben, foi reinventada pela filosofia continental de fins do

colectâneas: Gary GarstLE \& Joel IsAAC (Eds.), States of Exception in American History, University of Chicago Press, Chicago, 2020; Cosmin Cercel, Gian Giacomo Fusco, Simon Lavis (Eds.), States of Exception: Law, History, Theory, London: Routledge, 2020; Richard Albert/Yaniv Roznai (Eds.), Constitutionalism under Extreme Conditions: Law, Emergency, Exception, Springer, 2020.

19 Aqui, a negociação de facto e direito resolve-se por metodológica concentração progressiva no programa normativo e no âmbito material da norma (Müller), ou no encontro do pré-compreensivo juizo de um caso com as hipóteses normativas legalmente previstas (Esser) ou até das normas hipoteticamente construidas para o resolver com as disposiçóes efectivamente positivadas (Kriele). 
século XX e início dos XXI, sob inspiração da arqueologia foucaultiana e da teoria da violência de Walter Benjamin ${ }^{20}$, ao passo que a teoria constitucional norte-americana ${ }^{21}$ o revisitaria com afinco, no rescaldo dos ataques do 11 de Setembro e do novo paradigma internacional neobélico e internamente securitário, que veio a desencadear na América - e, progressivamente, um pouco por todo o mundo.

Posteriormente, a crise económica e financeira, pretextando a invocação de apósitos estados de emergência, gerou mais uma vaga de reconsideraçôes, que lhe alargaram e distenderam as fronteiras e o potencial significativo para os domínios da luta contra a normalização necessitante das formas de opressão e domínio patriarcal, neocolonial e económico-social, de alcance supra-estadual ${ }^{22}$.

\section{O quadro jurídico}

\subsection{TEORIA}

As situaçôes constitucionalmente relevantes de anormalidade prestam-se a variadas possibilidades de análise, autorizando a organização

20 Giorgio Agamben, Stato di eccezioni, Homo sacer, II, I, Bollati Boringhieri, Torino, 2003. V. igualmente a monumental edição completa da série dedicada ao homo sacer: Homo sacer (1995-2015). Ediz. Integrale, Quodlibet, Macerata, 2018; assaz menos convincentes se afiguram alguns dos últimos discreteios do autor, em especial o polémico conjunto de meditaçốes que foi produzindo no site desta sua editora e entretanto compilado em Idem, A che punto siamo? L'epidemia come politica, Quodlibet, Macerata, 2020.

21 Cf. Bruce Ackerman, "The Emergency Constitution”, The Yale Law Journal, Vol. 113, 2004, pp. 1029-1091 e a discussão gerada pelas posiçóes do professor de Yale: v.g., David Cole, The Priority of Morality. The Emergency Constitutions Blind Spot", The Yale Law Journal, 113, 2004, 1753 e ss; Kim Lane Scheppele, "Law in a Time of Emergency: States of Exception and the Temptations of 9/11", Journal of Constitutional Law, Vol. 6, 5, May, 2004, pp. 1001-1083; Laurence H. Tribe and Patrick O. Gudridge, "The Anti-Emergency Constitution”, Yale Law Journal, 113, 2004, pp. 1801 e ss; Martha Minow, "The Constitution as Black Box During National Emergencies: Comment on Bruce Ackerman's Before the Next Attack: Preserving Civil Liberties in an Age of Terrorism", Fordham Law Review, 75, pp. 593 (2006).

22 V., por exemplo, Lorenzo Cotula, "The state of exception and the law of the global economy: a conceptual and empirico-legal inquiry", Transnational Legal Theory, 8:4, 2017, pp. 424-454; José Atiles-Osoria, and D. Whyte, "State of Exception, Law and Economy: A socio-legal approach to the economy of exception in an era of crisis", in Oñati Socio-legal Series, 8 (6), 2018, pp. 808-818. Foram-se-lhe juntando, no interim, os desastres ambientais - mais ou menos localizados (como sucedeu com o furacão Katrina) e as epidemias surgidas sobretudo a oriente ou em África. 
de tipologias muito heterogéneas, conforme os critérios ou ao longo dos eixos de sistematização utilizados: tempos, sujeitos, poderes, medidas, efeitos, objectos, etc. Assim se admitem modelos e modalidades ditos monistas e dualistas, de autorização ou ratificação ${ }^{23}$, envolvendo poderes implícitos ${ }^{24}$ ou cláusulas expressas de habilitação ${ }^{25}$, estritamente vinculados, discricionários, de liberdade ou irresponsabilidade, ordinários ou extra-ordinários, jurídicos ou extra-jurídicos, constitucionais ou legislativos, politicos ou administrativos, suspensivos ou restritivos de direitos, etc. Cerzindo algumas das taxonomias mais conseguidas, talvez seja lícito estacionar na destrinça entre modelos de previsão e acomodação jurídica de irrelevância continuista e de reacção extra-jurídica ${ }^{26}$.

\subsection{DOGMÁTICA}

a) Nacional: face ao tratamento de que é objecto no próximo capítulo deste livro branco, dispensam-se, por ora, lucubraçóes minimamente detidas sobre o ponto vertente, satisfazendo-se a composiçáo discursiva com o ressalto de que o corpus constitucional luso permite distinguir entre estado de necessidade externo (de guerra ou emergência militar) e interno. Ladeada, dentro da modalidade em apreço, pelas situaçôes de grave ameaça ou perturbação da ordem constitucional democrática, a ocorrência de pandemias, a par de outras catástrofes naturais, desastres ou acidentes graves, deverá corresponder, salvo melhor aviso, aos problemas intencionados normativamente com a referência a

23 Pense-se nos britânicos Bills de indemnidade, por exemplo.

24 Como, em boa medida, sucede nos EUA.

25 Tenha-se em vista o tristemente célebre $480^{\circ}$ da Constituição alemã de Weimar e o $16 .^{\circ}$ da Constituição Francesa de 58.

26 Oren Gross/Fionnuala Ní Aolaín, Law in Times of Crisis. Emergency Powers in Theory and Practice, CUP, Cambridge, 2006; David Dyzenhaus, The Constitution of Law. Legality in Time of Emergency, Cambridge University Press, Cambridge, New York et al, 2006; John Ferejohn/Pasquale Pasquino, "The law of the exception: A typology of emergency powers", International Journal of Constitutional Law, Volume 2, Issue 2, April 2004, pp. 210-239; baseando-se precisamente nestes autores, v. entre nós, Miguel Nogueira de Brito, "Modelos de Emergência no Direito Constitucional", e-Pública, Volume 7, N. o 1, Abril, 2020, pp. 6-26; cfr. ainda Jorge Bacelar GouveiA, O Estado de Excepção no Direito Constitucional: Entre a Eficiência e a Normatividade das Estruturas de Defesa Extraordinária da Constituição, vol. II, Almedina, Coimbra, 1998; Idem, Estado de Exceção no Direito Constitucional: Uma Perspetiva do Constitucionalismo Democrático - Teoria Geral e Direito Português, Almedina, Coimbra, 2020. 
calamidades públicas ${ }^{27}$. Verificados os respectivos pressupostos materiais, a constituição prevê a possibilidade de instituir um regime ou disciplina jurídicos de necessidade, essencialmente consistente numa suspensão colectiva de direitos que o presidente pode declarar - optando pelo estado de sítio ou de emergência, consoante a gravidade dos casos (e apesar das ténues linhas que os separam) -, mediante decreto apresentado à AR, depois de ouvido o governo, e sujeito à referenda governamental se, e quando, autorizado (ou confirmado) por aquela ${ }^{28}$. Além destes limites formais, procedimentais e orgânicos, de um ponto de vista material, (i) excluem-se do alcance potencial de suspensão alguns direitos e princípios constitucionais ${ }^{29}$, (ii) requer-se a especificação dos direitos afectados, (iii) define-se uma limitação temporal para os seus efeitos, e (iv) impóe-se especial cautela na observância dos princípios da proibição do excesso, bem como, naturalmente, da igualdade e da não discriminação. $\mathrm{O}$ regime principial continua a actuar como parâmetro da declaração e das medidas adoptadas na sua execução, garantindo a possibilidade de sindicância jurisdicional, para lá do controlo político parlamentar.

b) Internacional: merece ainda a pena realçar, conquanto liminarmente, a guarida que à derrogaçáo de direitos prodigalizam o PIDCP (art.04), apoiado pela Declaração de Siracusa e o Comentário Geral 29, bem como a Regulamento sanitário internacional, maxime no seu artigo 43. Largamente ignorado durante a gestão estatal e internacional da pandemia, este complexo normativo motivou mesmo uma exortação à observância por parte de Lawrence Gostin e outros especialistas, ainda nos idos de Fevereiro de $2020^{30}$. Com um fito de elucidaçáo colimado sem dúvida a uma maior divulgação, impregnação e inculcação

27 J.J. Gomes Canotilho, Direito Constitucional e Teoria da Constituição, 7.a edição, Almedina, Coimbra, pp. 1083 e ss

${ }^{28}$ Além do art. $19 .^{\circ}$, v. $134 .$, n. ${ }^{\circ} 1$, al. d); $138 .^{\circ}, 140 .^{\circ}$, n.o $1 ; 161 .^{\circ}$, alínea l), e 197. ${ }^{\circ}$, n. ${ }^{\circ} 1$, alínea f), da CRP.

29 De harmonia com o que se acautela também no art. 4..$^{\circ}$ do PIDCP, no $27 .^{\circ}$ da Convenção Americana dos direitos Humanos, ou no artigo $15 .^{\circ}$ da CEDH.

30 "Do not violate the International Health Regulations during the COVID-19 outbreak", The Lancet, 20 February, 2020 
na consciência colectiva e à modelação da agência dos entes públicos responsáveis, assim como das populações, alcançou-se e firmou-se, há não muito, o Consenso de Stellenboch ${ }^{31}$ sobre as respostas jurídicas nacionais aos riscos de saúde pública, peça cujo conteúdo não consente em deslindar-se neste curto espaço, mas que convida a um estudo dos nexos jurídicos com que, de futuro, deve enredar as responsabilidades estaduais em matéria de saúde em geral, e de saúde pública em particular, com outras exigências, de solidariedade global, comércio internacional e tutela de direitos, em parte condicionantes, senão constitutivas, das faculdades/capabilidades reais de bem-estar e realizaçáo pessoal essenciais ao suporte mútuo da saúde individual e colectiva.

\section{A Narrativa Nacional ${ }^{32}$ : do Pathos ao Logos}

Se a história só recorda sismograficamente os acidentes, esquecendo, entre os cumes agrestes da mudança, os vales planos de morna felicidade, não deve surpreender-nos o fascínio e atracção dos seus cultores pelos fenómenos epidémicos. A propensão metafórica e a prestabilidade alegórica não hão de pesar menos nesse cômputo, ao qual se anexa ainda a forma dramatúrgica que tendem a assumir (Charles Rosenberg)

31 O texto pode ser consultado na International Organizations Law Review, 2020, $1-68$.

32 Para uma reconstituição muito semelhante, v. Teresa Violante \& Rui LanCEIro, "The Response to the COVID-19 pandemic in Portugal: A success story gone wrong”, Verfassungsblog, 04 March 2021; Idem, "Coping with Covid-19 in Portugal: From Constitutional Normality to the State of Emergency", Verfassungsblog, 12 April 2020; Pedro Lomba, "The Constitutionalized State of Emergency. The Case of Portugal”, Verfassungsblog, 15 April, 2020; Idem, "Constituição, estado de emergência e Administração sanitária: alguns problemas”, in e-Pública, Vol. 7, n. ${ }^{\circ}$ 1, Abril 2020, pp. 27-43; José Melo Alexandrino, "Devia o direito à liberdade ser suspenso? Resposta a Jorge Reis Novais", Observatório Almedina, 7 de Abril de 2020 (também em Revista do Ministério Público, Número Especial COVID-19: 2020, pp. 79-92); Jorge Bacelar Gouveia, "O estado de excepção no Direito Constitucional: uma introdução", Observatório Almedina, 26 de Março de 2020; Idem, "Portugal e a COVID-19: Balanço e Perspetivas de uma Ordem Jurídica da Crise", in Revista do Ministério Público, número especial COVID-19, ano 41, junho 2020; Catarina Santos Botelho, "Emergência preventiva, reactiva, cirúrgica, ...reforçada", Observatório Almedina, 25 de Janeiro de 2021. 
e a coreografia social que exibem à medida que se desenrolam no tempo e no espaço ${ }^{33}$.

Nos países lusófonos, a história conta-se a várias velocidades e ritmos, impossíveis de rastrear aturadamente, pelo que se acompanha apenas (e muito de alto), os meandros da novela portuguesa. Nela se divisam dois episódios de confinamento, iniciados em Março de 2020 e Janeiro de 2021, entremeados por um período de desconfinamento, a partir de Maio mas inflectido em Setembro; inclui três estados de emergência decretados em Março e Novembro (de 2020) e em Janeiro (de 2021), para conhecerem depois sucessivas renovaçôes; e escande-se, como num Leitmotiv, por uma duradoura e raro aliviada gestáo administrativa da calamidade, ao longo de quase todo este período. No elenco figuram actores institucionais de primeira monta, como o PR, a AR, o Governo, as Regiōes Autónomas, as Câmaras Municipais, a Administração da Saúde, os Tribunais e a Provedora, mas também os cidadãos e muitas das suas associaçóes cívicas e profissionais de representação (ordens, sindicatos, ligas, confederaçóes patronais, etc.), além dos meios de comunicaçáo social e das redes sociais - tornados postigos para o mundo de uma pletora de especialistas (promovidos da rectaguarda à antena) e de movimentos sociais mais ou menos inorgânicos. Entre muitos outros temas e, sobremodo, no meio de uma cópia imensa de pormenores náo despiciendos, três grandes questóes jurídicas mereceriam talvez um olhar mais demorado: a oportunidade e conteúdo da declaraçấo de estado de emergência e respectiva execução pelo governo; a administração em estado de calamidade; a realizaçáo de eleiçóes durante a pandemia - todas elas entretanto conducentes a propostas de iure condendo e lege ferenda, relativamente à constituiçáo e à legislaçáo vigente.

No essencial, os feitos podem narrar-se assim: face ao cenário internacional e apesar da ausência de casos em território português, a 2 de Março, o Governo começou a adoptar medidas restritivas, acobertado pela lei de protecçáo civil, pela lei de bases da saúde, e pela lei de vigilância sanitária. Uma forte pressão social, sobretudo por parte de profissionais de saúde, levou o PR a declarar o primevo estado de emergência, ainda que ao executivo fosse em princípio possível restringir os direitos afectados, no âmbito da reserva imanente de ponderação a que,

33 Jeremy A. Greene \& Dóra Vargha, "How Epidemics End”, June 30, 2020, in Thinking in a Pandemic: The Crisis of Science and Policy in the Age of COVID-19, op. cit. 
na formulação de Reis Novais, se encontram sujeitos ${ }^{34}$. Acresce que a declaração do Presidente náo suspendeu o direito à liberdade pessoal, precipuamente atingida pelo núcleo duro da intervenção governamental (e principal argumento para o recurso à sua suspensão, salvo erro), além de operar uma delegação de poderes de delimitação dos direitos suspensos cuja constitucionalidade náo se furta a dúvidas. Dificilmente se poderia dizer, em todo o caso, que as medidas do Governo se saldaram em mera execução do decreto presidencial, cabendo-lhes um papel afinal constitutivo, em termos materiais, na restrição dos direitos, razão por que deveriam ter revestido a forma legal, e não apenas regulamentar, como avonde veio a suceder. De todo o modo, após duas renovaçóes, sem alteraçóes significativas quanto a estes pontos problemáticos, o estado de emergência expirou a 2 de Maio, dando lugar a um estado administrativo de calamidade (por sua vez renovado até 28 de Junho), balizado pela legislação já citada, e sempre confiante na consciência cívica dos cidadáos, à medida que as restriçóes iam sendo gradualmente levantadas. Todavia, o sol de verão pouco durou, pois, em Setembro, os níveis de infecção voltaram a subir, ao mesmo tempo que novas estratégias, relacionadas com a vinculatividade do uso de máscaras e a equação de um sistema electrónico de rastreamento dos contactos humanos entraram na agenda; a primeira definitivamente, a segunda, titubeantemente, até se gorar por completo. $\mathrm{O}$ agravamento da situação ditou nova declaração de estado de emergência a 6 de Novembro, e o implemento de constrições mais severas durante o mês de Dezembro (recolhimento nocturno à semana, e desde as 13 horas, ao fim-de-semana). $\mathrm{O}$ fracasso da contenção ensejada durante o período festivo (quiçá devido à complexidade regulática das medidas), combinado com o surgimento precoce de novas estirpes no país, redundaram no período mais negro da pan-

34 Jorge Reis NovaIs, "Estado de Emergência - Quatro notas jurídico-constitucionais sobre o Decreto Presidencial", Observatório Almedina, 19 de Março de 2020; Idem, "Direitos Fundamentais e inconstitucionalidade em situaçáo de crise - a propósito da epidemia COVID 19", in e-Pública, Vol. 7., N. 1 Abril, 2020, pp. 78-117; Pedro Costa GonçALVEs, "Abdicação parlamentar na emergência e continuação da abdicação na calamidade", Observatório Almedina, 21 de Maio de 2020. Via semelhante recomendam vários autores, como Martin Scheinin, no plano internacional. Na Alemanha lamentou-se, inversamente, a ausência de medidas constitucionais expressamente invocáveis. Para uma panorâmica comparada da resposta, v. as ligaçóes contidas em Joelle Grogan, "Power and the COVID-19 Pandemic - Introduction \& List of Country Reports", VerfassungsBlog, 2021/2/22. 
demia, em Janeiro, induzindo novo confinamento, a meio do mês, ante os números alarmantes de óbitos e infecçóes, o congestionamento dos hospitais e a iminente ruptura do sistema. Não tendo sido precavida a realização, em maior segurança, das eleiçóes presidenciais, nada obstou, porém, a que o acto tivesse decorrido na data prevista. Pelo contrário. E se náo convencem completamente os argumentos expendidos em prol de um possível adiamento (sem prejuízo de os prazos constitucionais admitirem uma relativa dilacção), mais os sobrepuja a preocupação em manter uma salutar regularidade democrática. Da experiência se retira, todavia, a necessidade de ponderar tranquilamente uma reforma do sistema, ainda que sem embarcar numa ocasional e dermicamente reactiva alternativa electrónica, carente de estudos e debate; e isto porque veio à tona a impreparação logística da administração, particularmente no que diz respeito à modalidade de voto antecipado ${ }^{35}$.

A mais dos aspectos enfatizados, e de muitos outros focos de incontrovertido interesse, foram alvo de permanente discussão, i.a.: (i) a falta de profissionais (e os modos de a suprir, com importação imediata, alargamento da rede de instituiçóes formadoras, relaxamento das constriçôes corporativas, etc.); (ii) os protocolos comunicacionais das autoridades; (iii) os programas e planos de testagem e, mais tarde, de vacinação; (iv) os sistemas de atendimento e monitorização à distância (por via telefónica); (v) a estratégia de articulação entre sectores económicos incluídos no sistema de saúde em sentido amplo; (vi) a eventual definição de regras de priorização ou racionamento no acesso aos cuidados; (vii) os apoios financeiros disponibilizados e as soluçóes de apoio económico-social às despesas empresariais com pessoal; ou (viii) a privacidade acossada pela rápida telematizaçáo e a iminência do recurso a sistemas de rastreamento electrónico de doentes. Pistas para um robustecimento da capacidade de resposta à emergência e adversidade - da população como um todo, das cidades, das regiôes e do pais, dos vários sectores económicos e sobremodo, do serviço nacional de saúde.

35 Da qual ficaram excluídos cidadãos sob vigilância depois de 14 de Janeiro e que geraram longas esperas, nem sempre nas condiçóes sanitariamente mais aconselháveis, nos dias aprazados para o efeito. 


\section{Elementos para uma Paideia ${ }^{36}$}

Do impacto causado pela pandemia na nossa auto-compreensão como habitantes de uma só Terra e membros de uma comum Humanidade, retirar-se-ão, decerto, muitas ilaçóes - desejavelmente interligadas, e profundas - quanto aos valores e direitos humanos, às constituiçóes e ao direito, às estruturas sociais que os garantem e instanciam e aos sujeitos, praxis e instituiçóes dessa estruturante responsabilidade.

Fica apenas um punhado de indícios, algo soltos, já que sistematicamente percutidos nas recomendaçóes mais adiante avançadas pelo grupo de trabalho responsável por todo o projecto.

- No relativo à saúde, propriamente dita: (i) a telemedicina e a saúde electrónica em rápido crescimento pedem um planeamento pensado, que não menoscabe a importância do contacto humano; (ii) há que revalorizar significativamente a saúde pública em todas as suas vertentes, tendo em conta a pirâmide dos impactos e os círculos de co-determinação da saúde; (iii) a resposta prestacional carece de integração a vários níveis (afinal, os hospitais continuam essenciais) e requer uma apropriação comunitária, pela qual os cidadáos participem responsavelmente da sua organização e funcionamento; (iv) depois de anos de desvario, ganham acuidade, pois, i.a., as agendas de comunização, integração, universalidade, interseccionalidade e transversalidade.

- De um ponto de vista científico-cultural e comunicativo-informacional, (i) a ciência tem de ser colaborativa e prestigiada, objecto de apoio e reconhecimento financeiro e social; (ii) o acesso à rede (internet) erigiu-se em direito fundamental, cuja provisão não pode ser deixada ao bel talante de operadoras só controladas por reguladores tíbios (concentrados na garantia de uma concorrência económica de resultados miríficos); (iii) as escolas e os estabelecimentos de saúde constituem zonas primárias de investimento, logo na qualidade de espaços comuns, abertos à sociedade e essenciais para garantir a manutenção segura das relaçôes sociais presenciais em momentos de crise; (iv) a criação e divulgação e os hábitos e media culturais desempenham um papel insubstituível

36 Num sentido não totalmente coincidente, v. Andrew Buchwalter, "Constitutional Paideia: Remarks on Hegel's Philosophy of Law”, PAIDEIA, World Congress of Philosophy (Political Philosophy), Boston, August, 1998. 
(inclusive no domínio da saúde mental e familiar) face ao deslaçamento social e ao vazio existencial;(vii) sobre os meios de comunicação recaem responsabilidades acrescidas durante crises como a que vivemos, seja em matéria de esclarecimento público, seja como garantes da crítica e da pluralidade de opinióes, ou mesmo no exercício de funçóes educativas e pedagógicas primaciais.

- No que à economia, em geral, diz respeito, (i) a crise não afecta todos igualmente, neste como noutros aspectos; (ii) fica patente a vantagem de uma coexistência entre os sectores económicos, vincando bem as suas diferenças para um relacionamento mais fecundo; (iii) o planeamento mostra-se crucial; (iv) a cooperação internacional pede melhoramentos urgentes; (v) as cadeias logísticas não podem escapar ao escrutínio e controlo das colectividades; (vi) desenvolvimento não se confunde, de facto, com crescimento;

- No plano urbano e habitacional, (i) tornou-se evidente a corporealidade humana e a consequente necessidade de luxo comum, enquanto aposta no que é de todos como lugar de qualidade, segurança, higiene, bem-estar e sociabilidade (por isso resistente à privatização e idiotizaçáo completa das existências); (ii) em paralelo, porém, a qualidade do parque habitacional continua a constituir um problema maior, assim como a (iii) articulação de um e outro, em modelos urbanos concebidos para o homem, na interface que garantem entre a vida privada e pública, particular e comunitária.

Chega-nos de algures a evocação das cidades em pandemia como surreais paisagens de De Chirico, abandonadas de homens. Nódulos fundamentais de um constitucionalismo em rede para um mundo citadino global, em expansáo imparável, elas redescobrem-se, porém, como lugar, por excelência, da reinventada (e)utopia - clássica e medieva, moderna e contemporânea - de realização e florescimento do homem. Havemos, pois, de nos empenhar na imaginação pública que as transforme, comprometidos a honrar as esperanças que para elas e nós fomos sonhando nestes tempos de dispersão isolada. Se assim for(mos dignos), como alguém também já sugeriu, ecoando o discurso nobel de Neruda, mais cedo do que tarde chegará o dia em que, enfim,

"A l'aurore, armés d'une ardente patience, nous entrerons aux splendides Villes."

(Rimbaud) 


\section{DIREITO PÚBLICO E PANDEMIA}

Ana Raquel Gonçalves Moniz

\section{Introdluçáo}

A tutela do bem jurídico-constitucional saúde pública e a sua concretização num direito (objetivo) da saúde demonstrou a respetiva transversalidade (ou horizontalidade) e, no contexto do combate à pandemia, penetrou todas as dimensóes normativo-sociais e todos os ramos jurídico-dogmáticos. Todavia, talvez nenhuma matéria venha sentindo (pelo menos, com esta crescente intensidade) os influxos causados pela crise pandémica como o Direito Público. Tal resultou não só da circunstância de o cerne das preocupaçóes dos poderes públicos se concentrar na realização do direito à proteção da saúde (e do impacto nos serviços de saúde, enquanto mecanismo privilegiado dessa proteção), mas também (e como uma importância absolutamente não despicienda) do facto de a garantia da saúde pública e as medidas de prevenção e combate à COVID-19 haverem implicado uma afetação de diversos direitos fundamentais.

Neste horizonte, a convocação do(s) instituto(s) do estado de exceçấo representou um problema transversal a vários ordenamentos jurídico-constitucionais. As dificuldades têm, aqui e além, emergido nos vários Estados, assistindo-se a um crescendo no que tange à reação jurisdicional dirigida pelos titulares dos direitos contra as diversas medidas adotadas ao abrigo do(s) estado(s) de exceçáo declarado(s). Os problemas avolumam-se, sobretudo quando consideramos que a o desenvolvimento das medidas de prevenção e combate à pandemia decorreu (ainda que não exclusivamente) de atuações jurídico-administrativas, que desencadearam restriçóes jusfundamentais várias. 


\section{Estados de exceçáo e afetaçáo de dirieitos}

A natureza relativamente súbita do surgimento da COVID-19 obrigou os ordenamentos jurídicos a reagir através do(s) instituto(s) do(s) estado(s) de exceção. Em Portugal, a mobilização da figura do estado de emergência no quadro da Constituiçấo de 1976, ocorreu, pela primeira vez, neste momento, sem prejuízo da sua consagração desde a versão originária da CRP. Ademais, e diversamente do que sucedeu noutros horizontes ${ }^{1}$, os sistemas ocidentais (incluindo os sistemas jurídicos lusófonos) confrontaram-se com a projeção jurídica dos efeitos de uma pandemia no plano dos direitos fundamentais, enquadrada por uma moldura normativa nem sempre clara. A conjugação entre estas dimensóes impóe-nos que consideremos, sucessivamente, três questôes: a distinção entre situações de normalidade e situações de exceção (2.1.); a centralidade assumida pelo Executivo, no contexto da resposta à crise (2.2.); a necessária subordinação das medidas de crise à juridicidade, sublinhando que os estados de exceção (constitucional ou administrativo) não operam fora do Estado de direito (2.3.).

\subsection{Os direitos fundamentais entre a normalidade e a exceçáo}

As circunstâncias atuais colocam-nos perante a necessária distinção entre situaçóes de normalidade e situaçóes de exceção, ou, numa outra perspetiva, entre o «direito da normalidade» e o "direito da

1 Atente-se nos Estados (orientais) afetados, logo no dealbar do século XXI, pelo surto de SARS, e cujas reaçóes se vêm considerando como exemplares, porquanto, após aquela epidemia, os instrumentos de resposta se desenvolveram e aprimoraram, criando planos de saúde pública e, como tal, conferindo às autoridades públicas uma preparedness, também no horizonte da organização e do planeamento político-administrativos, que, por sua vez, lhes atribuiu mecanismos de reação mais céleres e eficientes: eis o sucedeu, $v$. $g$., com Singapura ou Taiwan. Cf. ShaAban/Peleteiro/ Martins, "COVID-19: What Is Next for Portugal?», in: Frontiers in Public Health, vol. 8, 2020, 392 (doi: 10.3389/fpubh.2020.00392). Também na Região Administrativa Especial de Macau, a epidemia causada pelo SARS entre 2001 e 2003 permitiu uma aprendizagem que culminou na aprovação da Lei n.o 2/2004 (lei de prevenção, controlo e tratamento de doenças infeciosas), cujos mecanismos foram, de imediato, convocados para debelar a pandemia - v. Vera Raposo/Man Teng Iong, «The Struggle Against CoViD-19 Pandemic in Macao", in: BioLaw Journal | Rivista di BioDiritto, n. ${ }^{\circ}$ especial 1, 2020, pp. 747 e ss.. 
crise» ${ }^{2}$. No caso português, o combate à pandemia conduziu à mobilização de instrumentos jurídicos de excecionalidade, quer do estado de exceção constitucional (como sucedeu com o estado de emergência), quer dos "estados de exceção administrativos" (especiais) 3 decorrentes da Lei de Bases da Proteção Civil (LBPC) ${ }^{4}$ e da Lei de Bases da Saúde $(\mathrm{LBS})^{5}$, em articulação com a Lei do sistema de vigilância em saúde pública (LVSP) ${ }^{6}$. Em geral, e quando concebidas como formas de "estado de necessidade", estas figuras consubstanciam um modo de legalização de atuaçôes que, praticadas sob outro circunstancialismo, seriam inválidas, em cenários de perigo iminente e/ou atual para interesses superiores aos sacrificados, perigo esse náo imputável ao autor da lesão.

Se, evidentemente, a adoção de cada um dos estados de exceção referenciados depende do preenchimento de pressupostos próprios e possui uma duração (em parte) diferenciada, também da perspetiva da afetação dos direitos fundamentais, os respetivos efeitos são distintos. Se os estados de exceçáo constitucional conduzem, no sistema jurídico português, à possibilidade de suspensão do exercício de direitos fundamentais, as restantes hipóteses apenas admitem a respetiva restrição - em consonância (pelo menos, tendencial) com a gravidade das situaçôes que lhes estão subjacentes.

2.1.1. Assim, nas situaçóes mais graves - em que se encontre decretado o estado de sítio ou o estado de emergência -, o artigo $19 .^{\circ}$ da CRP prevê a possibilidade de suspensão de direitos fundamentais. Tal obedece, evidentemente, a um conjunto de limites que a própria Constituição traça, entre os quais pretendemos salientar dois - um no plano orgânico-formal; outro de cariz material.

2 Bacelar Gouveia, «Portugal e a COVID-19: Balanço e Perspetivas de uma Ordem Jurídica da Crise», in: Revista do Ministério Público, número especial COVID-19, ano 41, junho 2020, p. 94.

3 Cf. também Pedro Gonçalves, Manual de Direito Administrativo, vol. 1, Almedina, Coimbra, 2019, pp. 391 e 392, destrinçando o estado de necessidade administrativo (enquanto regra geral constante do CPA), das "regras especiais do direito de emergência" (itálico no original), que consubstanciam um regime próprio.

${ }^{4}$ Lei n. $^{\circ}$ 27/2006, de 3 de julho, alterada pela Lei Orgânica n. ${ }^{\circ}$ 1/2011, de 30 de novembro, e pela Lei n. ${ }^{\circ}$ 80/2015, de 3 de agosto.

5 Aprovada pela Lei n. ${ }^{\circ}$ 95/2019, de 4 de setembro.

6 Lei n. ${ }^{\circ} 81 / 2009$, de 21 de agosto. 
Por um lado, a declaração do estado de sítio ou do estado de emergência pressupóe uma articulaçáo significativa entre os órgãos de soberania: no caso português, o Presidente da República, o Governo e o Parlamento, no horizonte de um verdadeiro esquema de freios e contrapesos, tal como decorre de uma adequada compreensão do princípio da separação e interdependência entre poderes. $\mathrm{O}$ desenho procedimental que precede a declaraçáo presidencial do estado de emergência envolve a audição do Governo, a autorização da Assembleia da República [nos termos dos artigos $138 .^{\circ}, 161 .^{\circ}$, alínea l), e $197 .^{\circ}$, n. ${ }^{\circ} 1$, alínea $f$ ), da $\mathrm{CRP}^{7}$ ], bem como o controlo parlamentar da sua específica execução [cf. artigo $162 .^{\circ}$, alínea $b$ ), da $\mathrm{CRP}^{8}$ ]. Também o esquema constitucional de organizaçáo do poder político (incluindo os órgãos de governo próprio das regióes autónomas) representa uma matéria que permanece intocada com a declaração de estado de sítio ou de estado de emergência (cf. artigo $19 .^{\circ}$, n. ${ }^{\circ} 7$, da CRP).

Por outro lado, importa acentuar que o regime do estado de exceçáo constitucional também apresenta limites materiais. Desde logo, e sem prejuízo da imprescindível observância das exigências de sentido do princípio da proporcionalidade (cf., em especial, artigo 19. ${ }^{\circ}$, n. ${ }^{\text {os }} 4$ e 8, da CRP) e do princípio da excecionalidade e limitaçáo da suspensão ${ }^{9}$, o n. ${ }^{\circ} 6$ do artigo $19 .^{\circ}$ da Lei Fundamental impede a suspensão dos direitos à vida, à integridade pessoal, à identidade pessoal, à capacidade civil e à cidadania, à não retroatividade da lei penal, do direito de defesa dos arguidos e da liberdade de consciência e de religião.

Afigura-se ainda notória a influência portuguesa nos Estados lusófonos, muitos deles a optar por um modelo de estado de excecionalidade constitucional, que, também com o objetivo de restaurar a ordem

7 Cf. também artigo $100^{\circ}$ do Regime do estado de sitio e do estado de emergência (RESEE - Lei n. ${ }^{\circ} 44 / 86$, de 30 de setembro, alterada pelas Leis Orgânicas n. ${ }^{\text {os }}$ $1 / 2011$, de 30 de novembro, e 1/2012, de 11 de maio). A tramitaçáo do procedimento encontra-se contemplada nos artigos $23 .^{\circ}$ e seguintes deste mesmo diploma.

O decreto do Presidente da República que declare o estado de sítio ou o estado de emergência [cf. artigo $134 .^{\circ}$, n. $^{\circ} 1$, alínea $d$ ), da CRP] encontra-se ainda sujeito a referenda ministerial, de acordo com o prescrito no n. ${ }^{\circ} 1$ do artigo $140 .{ }^{\circ}$ da Constituiçáo. $V$. também artigo $11 .^{\circ}$ do RESEE).

8 Cf. também artigo $28 .^{\circ}$ do RESEE.

9 Cf. Jorge Miranda, «Artigo 19. ${ }^{\star}$ ", in: Jorge Miranda/Rui Medeiros (dir.), Constituição Portuguesa Anotada, tomo I, 2. a ed., Coimbra Editora, Coimbra, 2010, p. 410 . 
constitucional, prevêem a possibilidade de suspensão (e, em certos casos, também de limitaçáo) de direitos fundamentais, com caráter temporário (cf. tabela 1).

Assim os artigos 282 a 284 da Constituição de Moçambique consagram o estado de sítio e o estado de emergência, em caso de agressão efetiva ou eminente, de grave ameaça ou de perturbação da ordem constitucional ou de calamidade pública (reservando-se o estado de emergência para os casos em que os pressupostos se revistam de menor gravidade), cuja declaração permite a suspensão e limitação de direitos, com uma duração não superior a 30 dias, sendo prorrogável por iguais períodos até três vezes, se persistirem as razóes que determinaram a sua declaração. Considere-se ainda o artigo $58 .^{\circ}$ da Constituição angolana, que contempla as figuras do estado de guerra, estado de sítio e estado de emergência, a mobilizar em situações de agressão efetiva ou iminente por forças estrangeiras, de grave ameaça ou perturbação da ordem constitucional democrática ou de calamidade pública, determinando a suspensão e limitação de direitos (sem a possibilidade de afetar o direito à vida, à integridade pessoal e à identidade pessoal, a capacidade civil e a cidadania a não retroatividade da lei penal, o direito de defesa dos arguidos; e a liberdade de consciência e de religiáo).

A Constituição brasileira conhece, neste contexto, uma diferenciação material mais significativa, com uma projeção no desenho dos regimes jurídicos aplicáveis, entre o estado de defesa e o estado de sítio (cf. artigos 136 e 137 da Constituição Federal, respetivamente): se o primeiro se encontra vocacionado para a preservação ou o pronto restabelecimento, em locais restritos e determinados, da ordem pública ou da paz social ameaçadas por grave e iminente instabilidade institucional ou atingidas por calamidades de grandes proporçôes na natureza, admitindo apenas a restrição de direitos (com uma duração não superior a 30 dias, sem prejuízo da possibilidade de prorrogação mas apenas por uma vez, por igual período), o segundo dirige-se a reagir contra a comoção grave de repercussáo nacional ou ocorrência de fatos que comprovem a ineficácia de medida tomada durante o estado de defesa ou declaraçáo de estado de guerra ou resposta a agressão armada estrangeira, envolvendo já a suspensão de direitos (por um período não superior a 30 dias, sem prejuízo de prorrogaçóes sucessivas por iguais períodos, ou, quando aplicável, enquanto perdurar a guerra ou a agressão armada). 
2.1.2. A par e independentemente deste regime muito específico, o ordenamento português conhece um conjunto de disposiçóes que admitem a adoção de medidas de excecionalidade em circunstancialismos muito díspares (nem todos associados - rectius, independentemente da sua associação - à proteção da saúde pública). Eis o que sucede com os instrumentos decorrentes da LBPC: as declaraçôes de situaçáo de alerta, de contingência ou de calamidade, previstas neste diploma, consistem em mecanismos destinados, em geral, a atenuar os riscos coletivos e limitar os seus efeitos no caso de ocorrência de acidente grave ou de catástrofe (cf. artigo $1 .^{\circ} \mathrm{da}$ LBPC), pressupondo um crescendo na gravidade da ocorrência, projetada na intensidade das medidas a adotar e no órgáo com competência para as emitir (cf. artigos 8. ${ }^{\circ}, 99^{\circ}, 13 .^{\circ}$ e seguintes, da LBPC). Em particular, os atos jurídicos e as operaçóes materiais praticados ao abrigo da declaração de situação de calamidade e com o propósito de lhe dar execuçáo presumem-se praticados em estado de necessidade (cf. artigo $23 .^{\circ}$, n. $^{\circ} 2$, da LBPC) e podem envolver limitaçóes a direitos fundamentais, como a propriedade privada ou a livre iniciativa económica privada (cf. artigos $23 .^{\circ}$, n. ${ }^{\circ} 1$, e $24 .^{\circ}$, da LBPC).

No contexto de crises de saúde pública, o artigo $17 .^{\circ}$ da LVSP pública confere poderes extensos ao membro do Governo responsável pela área da saúde. Ao contrário do que parece sugerir a respetiva epígrafe ("poder regulamentar excecional"), este preceito contempla medidas de exceção que não se reconduzem apenas à emissão de regulamentos, envolvendo aquela norma uma habilitação genérica para a prática de atos administrativos que impliquem a restriçáo, a suspensão ou o encerramento de atividades, a separação de pessoas que náo estejam doentes, meios de transporte ou mercadorias que tenham sido expostos, de forma a evitar a eventual disseminação da infeção ou contaminação. Tal significa, pois, que, ao abrigo deste preceito, pode o Governo adotar medidas (primárias?) restritivas de direitos fundamentais, atingindo, $v$. g., a liberdade de deslocação, o direito de reunião ou a livre iniciativa económica privada.

\subsection{A centralidade do Executivo}

A operacionalização do «direito da crise» implica, em regra, um reequilíbrio dos vários poderes, determinando a centralidade do poder 
executivo em geral e do Governo em especial. Assim, as situaçóes de exceção e as respostas encontradas para a respetiva reação acabam por implicar uma preponderância do Executivo, mesmo quando (como sucede entre nós) a competência para a declaração (do estado de emergência) se encontra cometida ao Chefe de Estado dotado de legitimidade democrática direta.

2.2.1. Desde logo, a execução nacional da declaração do estado de emergência encontra-se cometida ao Governo (cf. artigo $17 .^{\circ}$ do RESEE), enquanto órgão superior da Administração Pública. Repare-se ainda que a CRP mobiliza a expressáo "autoridades" (cf. artigo 19. , n. ${ }^{\circ} 8$ - recuperado pelo artigo $19 .^{\circ}$ do RESEE) para designar as entidades competentes para adotarem as providências adequadas e necessárias ao pronto restabelecimento da ordem constitucional - o que, por sua vez, remete para a Administração ${ }^{10}$ [naturalmente, sob a direção (hoc sensu) do Governo] um papel determinante logo na conformaçáo das medidas, mas também na respetiva execução. $\mathrm{O}$ facto de a lei impor um dever de informação ao Presidente da República e à Assembleia da República incidente sobre as medidas de execução não afasta o protagonismo governamental, mas enfatiza o relevo da responsabilização política deste órgão perante aqueloutros.

Assume, neste horizonte, uma importância náo despicienda a figura do regulamento administrativo: eis a natureza jurídica que assumiram as normas (ou, pelo menos, a maioria delas) constantes dos diversos decretos governamentais que vêm concretizando a declaraçáo do estado de emergência emanada pelo Presidente da República ${ }^{11}$. Esta forma de ação administrativa exerce aqui uma função de execuçáo, enquanto instrumento normativo imprescindível para atuar a disciplina jurídica decorrente da declaraçáo do estado de exceçáo constitucional.

10 No contexto específico do estado de sítio/estado de emergência, cf. Bacelar Gouveia, Estado..., cit., p. 190.

11 Cf. Decretos n. ${ }^{\text {s }} 2-\mathrm{A} / 2020$, de 20 de março, 2-B/2020, de 2 de abril, $2-\mathrm{C} / 2020$, de 17 de abril, 2-D/2020, de 30 de abril, 8/2020, de 8 de novembro, 9/2020, de 21 de novembro, 11/2020, de 6 de dezembro, 11-A/2020, de 21 de dezembro, 2-A/2021, de 7 de janeiro, 3-A/2021, de 14 de janeiro, 3-B/2021, de 19 de janeiro, 3-C/2021, de 22 de janeiro, 3-D/2021, de 29 de janeiro, 3-E/2021, de 12 de fevereiro, 3-F/2021, de 26 de fevereiro, e Decreto n. ${ }^{\circ}$ 4/2021, de 13 de março. 
2.2.2. Também a declaração de situação de calamidade, baseada na LBPC, reforçou esta centralidade do Governo. Em situaçóes de emergência grave em saúde pública, particularmente perante situaçóes de calamidade ou catástrofe, o membro do Governo responsável pela área da saúde toma as medidas necessárias de exceção que forem indispensáveis, coordenando a atuação dos serviços centrais do Ministério com as instituiçôes e serviços do SNS e as autoridades de saúde de nível nacional, regional e municipal (cf. artigo $5 .^{\circ}$, n. ${ }^{\circ} 4$, do Decreto-Lei n. ${ }^{\circ}$ 82/2009). Na mesma linha se orienta, como sublinhámos, a citada Lei n. $81 / 2009$, que, em caso de emergência em saúde pública, confere poderes administrativos excecionais ao membro do Governo responsável pela área da saúde (cf. artigo 17. ${ }^{\circ}$ ). Neste horizonte normativo, os problemas práticos reconduziram-se à circunstância de, no âmbito da designada primeira vaga, algumas das medidas adotadas como execução do estado de emergência se haverem prolongado, posteriormente ao abrigo da situação de calamidade ou do sistema de vigilância em saúde pública.

\subsection{Os meios jurisdicionais de defesa dos direitos fundamentais}

A fixação constitucional e legal de pressupostos e condições de estados de exceçáo indica nitidamente que não estamos aqui no âmbito de uma zona fora do princípio da juridicidade, mas, pelo contrário, que os poderes públicos se encontram a agir ainda no quadro de um Estado de direito.

Salvaguardadas as hipóteses em que o litígio emerge de uma (eventual) violação do direito à liberdade, e, por conseguinte, se reconduz à reação contra uma detenção ilegal, os "remédios" utilizados para o controlo da juridicidade da atuação dos poderes públicos no que tange à afetação dos direitos fundamentais relevam, sobretudo, da Justiça Administrativa e/ou da Justiça Constitucional. Entre nós (mas à semelhança do que sucede em outros ordenamentos), são já alguns (embora não muitos) os processos que, tendo chegado ao Tribunal Constitucional ${ }^{12}$

12 Cf. Acórdãos n. os 424/2020, de 31 de julho, e 687/2020, de 26 de novembro. Entretanto, já deu entrada no Tribunal Constitucional, em 23 de novembro de 2020, um pedido de declaração de inconstitucionalidade com força obrigatória geral, apresentado pela Provedora de Justiça, de normas que contendem com o direito de propriedade e a livre iniciativa económica privada), mas que, em virtude da ausência de prazo associada a este processo, ainda não constituiu objeto de decisão. 
ou ao Supremo Tribunal Administrativo ${ }^{13}$, se debruçaram sobre a constitucionalidade/legalidade das medidas adotadas no contexto da pandemia que contendem com direitos fundamentais (cf. tabela 3).

Uma análise preliminar da jurisprudência disponível em Portugal permite antecipar três reflexóes:

a) Apesar de, no que respeita à jurisdição administrativa, não dispormos de dados sobre os tribunais de primeira instância, afiguram-se, em termos comparativos ( $v . g$., com os casos alemão e francês), relativamente escassos os processos intentados para defesa dos direitos fundamentais. Não nos parece, porém, poder inferir necessariamente deste dado que as medidas adotadas náo suscitem dúvidas sobre a respetiva constitucionalidade (ou legalidade) - como, aliás, decorre da aposição de declaraçóes de voto em dois dos Acórdãos;

b) Sem prejuízo dos dois arestos do Tribunal Constitucional tirados em recursos de constitucionalidade, foram dirigidos à Justiça Administrativa os processos para a tutela de direitos fundamentais, em particular de intimação para a proteção de direitos, liberdades e garantias - cujas decisóes, fazendo jus à qualificação como processo urgente, foram proferidas de modo célere, traduzindo um autêntico cumprimento do direito de tutela jurisdicional efetiva e consolidando a função dos tribunais como defensores dos direitos fundamentais e do Estado de direito;

c) A apreciação da juridicidade das medidas apontou para a mobilização de princípios normativos fundamentais, como sucedeu, paradigmaticamente, com o princípio da proporcionalidade ou com o princípio da igualdade. Todavia, uma tal convocação também acabou por revelar algumas das perplexidades subjacentes aos juízos valorativos que pressupóem e as debilidades emergentes dos seus entendimentos tradicionais.

13 Cf. Acórdãos de 10.09.2020 (P. 088/20.8BALSB), 31.10 .2020 (P. 01958/20.9BELSB) e de 31.10.2020 (P. 0211/20.1BALSB), Despachos de 20.11.2020 (P. 2090/20.0BELSB) e de 23.12.2020 (P. 143/20.4BALSB), e Acórdão de 05.02.2021 (P. 012/21.0BALSB). 


\section{Reflexốes finais}

As consideraçóes anteriores demonstram que as projeçóes jurídicas da pandemia se volvem, a final, num "teste de esforço" do próprio Estado de direito, cuja defesa assume especial relevo em momentos de crise. A experiência atual rasga caminhos para reflexóes ulteriores, quer a nível do Direito Constitucional, quer no plano do Direito Administrativo.

A relativa incipiência de instrumentos juridicamente admissíveis de resposta à pandemia gerou alguma indefinição no que tange à forma $\mathrm{e}$ ao grau de afetação dos direitos - entendidos como um dos pilares do Estado de direito. Esta crise veio atestar que, também no plano do(s) direito(s), a preparedness representa um aspeto primordial para a evolução dos regimes jurídicos, impondo-se uma reflexão e um aprimoramento, a posteriori, sobre a matéria ${ }^{14}$. Neste contexto, ressalta-se, do lado europeu (e, portanto, num horizonte jurídico-cultural mais próximo do nosso que as experiências asiáticas), a Infektionsschutzgesetz alemá que, tendo entrado em vigor já em 2001, estabelecia um quadro normativo relativamente sólido para situaçóes análogas (embora sem a dimensão da COVID-19), mas que, ainda assim, teve de sofrer alterações significativas durante a pandemia, entre as quais a introdução de um estado de "situação epidemiológica de importância nacional".

Repare-se que, a ser elaborada, em qualquer sistema jurídico, uma lei de proteção epidemiológica ou de emergência sanitária, a mesma exigirá não só uma adequada articulação com o sentido da existência de um estado de exceção constitucional com fundamento em calamidade pública (ou instituto análogo), como também uma reflexão e uma ponderação em matéria de conformação/limitação/restrição de direitos

$14 \mathrm{O}$ ordenamento jurídico português esteve quase a lograr uma posição dianteira nesta matéria: na verdade, a Base XIII do Projeto de Proposta de Lei de Bases da Saúde (cf. Lei de Bases da Saúde: Materiais e Razóes de um Projeto, Cadernos da Lex Medicinae n. ${ }^{\circ}$ 3, Instituto Jurídico | Faculdade de Direito da Universidade de Coimbra, Coimbra, 2018, pp. 47 e s.) previa o desenvolvimento e a implementaçáo de instrumentos de observação em saúde, nomeadamente de monitorização e vigilância epidemiológica, assim como o desenvolvimento de um sistema de saúde pública que permitisse identificar, avaliar, gerir e comunicar situaçóes de risco relativamente a doenças transmissíveis e outras ameaças à saúde pública, e a preparação e atualização sistemáticas de planos de contingência face a situaçóes de emergência ou de calamidade pública, determinando as medidas temporárias necessárias à proteção da saúde pública. Infelizmente, nenhum destes aspetos acabaria por transparecer na Base 10 da nova LBS... 
fundamentais, sobretudo, direitos, liberdades e garantias e da possibilidade e do grau de intervençáo normativa da Administraçáo neste horizonte. A elaboração de uma lei sobre tal matéria terá a vantagem de se encontrar mais bem apetrechada para dar resposta a uma situação pandémica (que apresenta especificidades face a outras hipóteses de calamidade ou catástrofe). Além de problemas específicos relacionados com a conveniência ou mesmo a legitimidade da interferência do direito no exercício da medicina (como sucede, $v$. g., nas questóes relativas à triagem de doentes), adivinham-se problemas que tocam o próprio âmbito de proteção de direitos fundamentais (e, correlativamente, do desenho das respetivas hipóteses de restrição) como sucederá, por exemplo, com o direito à intimidade da vida privada e à autodeterminaçáo informativa (e as questóes - muito diversas entre si - decorrentes quer da eventual obrigatoriedade da utilização de aplicações de geolocalização e de rastreio de contactos, quer do registo e publicitação das pessoas vacinadas, nomeadamente através da emissão de "passaportes de imunidade COVID-19" ou "certificados sanitários", quer do controlo de temperatura corporal), ou o direito à integridade física (e questôes relacionadas com a vacinação obrigatória), ou mesmo a liberdade de iniciativa económica ou a liberdade de empresa (e as soluçôes relacionadas com a gestão de redes de comunicação e do respetivo tráfego, de modo a dar prioridade à prestação de serviços críticos). A estes problemas associam-se ainda as dimensóes materiais relacionadas com a observância das exigências de sentido do princípio da proporcionalidade, ou as dimensôes formais atinentes ao princípio da determinabilidade das normas ou da densidade normativa acrescida em todas as disposiçóes que toquem direitos, liberdades e garantias.

Considerando que a pandemia e as respetivas consequências sanitárias, mas, sobretudo, económicas constituem um desafio social normativamente relevante, as mesmas exigirão certamente reflexôes que importarão mutações significativas no desenvolvimento do direito público, as quais, todavia, não poderão colocar em xeque as exigências de sentido dos princípios estruturantes do Estado de direito, da democracia e da socialidade. 


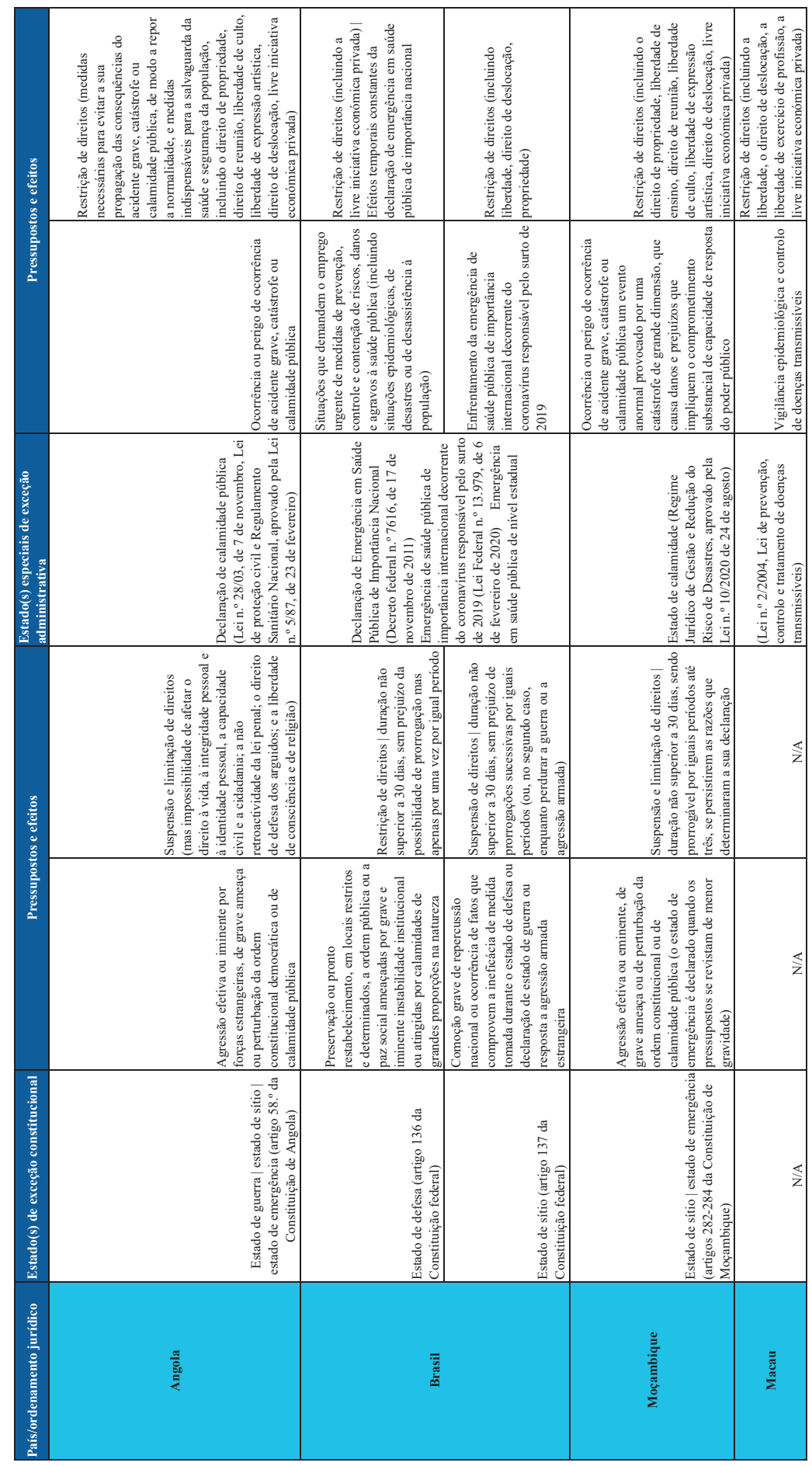




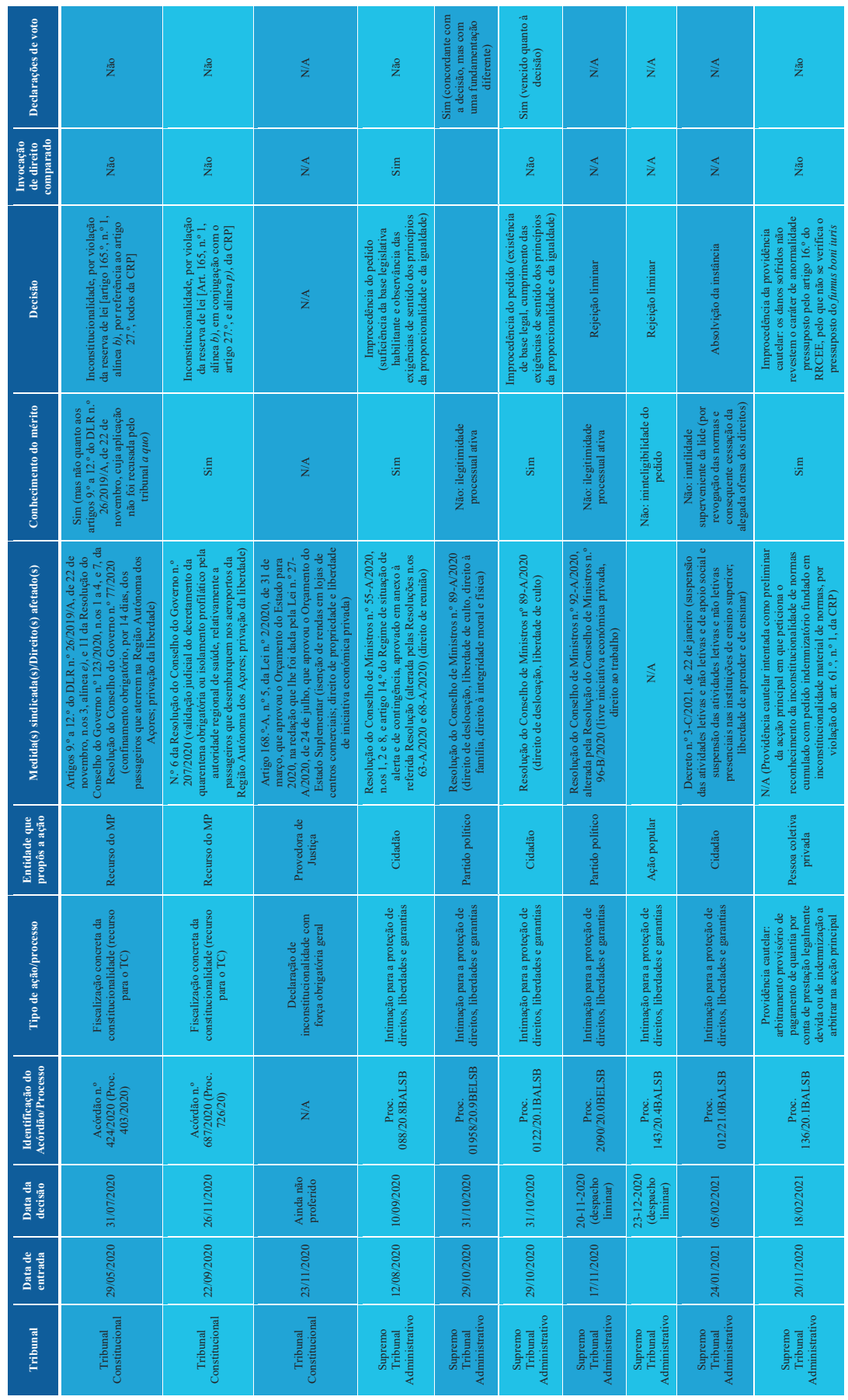




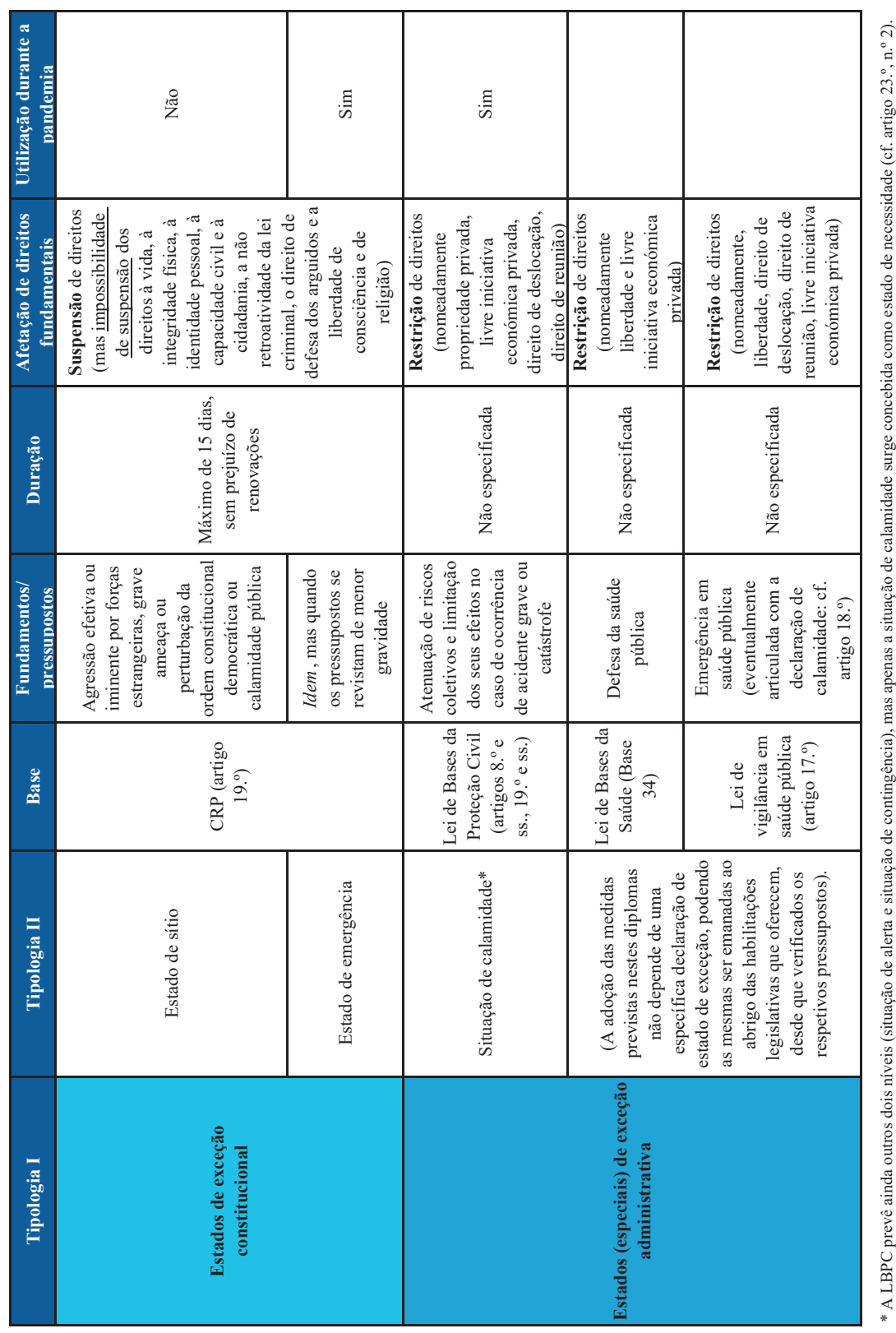




\title{
5. DIREITO SANCIONATÓRIO EM TEMPOS DE PANDEMIA
}

\author{
InÊs Fernandes Godinho
}

\section{Introduçáo}

Em tempos de pandemia, o direito sancionatório é um dos instrumentos ao dispor dos Estados, quer pelo papel dissuasor que poderá representar, quer pela vertente repressiva de comportamentos que possam pôr em causa as medidas impostas pelos Estados para combater a pandemia. Assim, o percurso assentará em uma perspectiva que contemple tanto o direito vigente, como eventuais normas sancionatórias criadas em virtude da pandemia, tendo fundamentalmente em conta o direito penal, mas também o direito contraordenacional.

Procurar-se-á também dar nota de algumas tendências identificadas no recurso ao direito sancionatório.

\section{Legislação penal}

\subsection{Em vigor}

- Para proteção da saúde pública

Em termos de legislação penal, podem ser referidos os artigos $282^{\circ}$ (Corrupção de substâncias alimentares ou medicinais) e 283 (Propagação de doença, alteração de análise ou de receituário) do Código Penal português (doravante, $\mathrm{CP}$ ). Ainda que possa ser discutido pela doutrina se o bem jurídico protegido por estes tipos penais é a saúde pública, na 
conceção relevante em contexto de pandemia ${ }^{1}$ - visando antes a proteção da vida e da integridade física, tendo em conta a sua construção típica $^{2}$-, eles são, também, no âmbito do $\mathrm{CP}$, aqueles que maior relevância assumirão neste contexto ${ }^{3}$, estando inseridos sistematicamente no CP no título dos crimes contra a vida em sociedade, no capítulo referente aos crimes de perigo comum.

Nos termos do art. $282^{\circ}$ do CP,

1. Quem:

a) No aproveitamento, produção, confecção, fabrico, embalagem, transporte, tratamento, ou outra actividade que sobre elas incida, de substâncias destinadas a consumo alheio, para serem comidas, mastigadas, bebidas, para fins medicinais ou cirúrgicos, as corromper, falsificar, alterar, reduzir o seu valor nutritivo ou terapêutico ou lhes juntar ingredientes; ou

b) Importar, dissimular, vender, expuser à venda, tiver em depósito para venda ou, por qualquer forma, entregar ao consumo alheio substâncias que forem objecto de actividades referidas na alínea anterior ou que forem utilizadas depois do prazo da sua validade ou estiverem avariadas, corruptas ou alteradas por acçáo do tempo ou dos agentes e a cuja acção estâo expostas;

e criar deste modo perigo para a vida ou para a integridade física de outrem é punido com pena de prisão de um a oito anos.

2. Se o perigo referido no número anterior for criado por negligência, o agente é punido com pena de prisão até cinco anos.

3. Se a conduta referida no n. ${ }^{\circ} 1$ for praticada por negligência, o agente é punido com pena de prisão até três anos ou com pena de multa.

$\mathrm{O}$ art. $282^{\circ}$ do CP, considerando a corrupção de substância medicinal ou cirúrgica, poderá assumir particular relevância, especialmente

1 No Decreto-Lei n. ${ }^{\circ}$ 28/84, de 20 de Janeiro, relativo às infraçóes antieconómicas e contra a saúde pública, o único crime claramente orientado para a proteção da saúde pública é o abate clandestino (art. $22^{\circ}$ do Decreto-Lei n. ${ }^{\circ} 28 / 84$ ), o qual náo é claramente adequado ao problema pandémico que serve de orientação a este trabalho.

2 Cfr. J. M. Damiáo da Cunha, Anotaçáo ao Art. 282º, in: Jorge de Figueiredo Dias (Dir.), Comentário Conimbricense do Código Penal, Tomo II, Coimbra: Coimbra Editora, 1999, p. 998 e s., p. 999; J. M. Damião da Cunha, Anotação ao Art. 283º, in: Jorge de Figueiredo Dias (Dir.), Comentário Conimbricense do Código Penal, Tomo II, Coimbra: Coimbra Editora, 1999, p. 1006 e s., p. 1007-1008.

3 E que encontramos paralelo, também, em outros ordenamentos jurídicos aqui considerados. 
tendo em conta as situaçóes descritas no tipo legal, tendo em conta a actual importância das vacinas para a COVID-19.

Aliás, em particular quanto a substâncias medicinais ou cirúrgicas, importa fazer uma referência adicional.

A Convenção do Conselho da Europa relativa à contrafacção de medicamentos e infracçóes semelhantes que envolvam ameaças à saúde pública (Convenção Medicrime), tendo sido aberta à assinatura em outubro de 2011, foi ratificada por Portugal em 2018, tendo entrado em vigor no ordenamento jurídico português em 1 de abril de 2019. Os artigos $5^{\circ}$ a $9^{\circ}$ da Convenção estabelecem diversas obrigaçóes de criminalização de falsificação e adulteração de produtos médicos, tendo como referente a saúde pública. Existem duas notas para que podemos chamar a atençáo. Em primeiro lugar, a Convençáo tem um leque de objectos mais amplo do que o art. $282^{\circ}$ do CP: enquanto o segundo considera apenas as substâncias medicinais para fins medicinais ou cirúrgicos - "substâncias que com propriedades, curativas ou não, se atribuam cientificamente virtudes diagnósticas, profiláticas, terapêuticas ou anestésicas em relação à saúde humana" ${ }^{-}$- a Convenção inclui, na sua formulação, aparelhos médicos ou acessórios desses aparelhos, que não se podem incluir no art. $282^{\circ} \mathrm{CP}^{5}$. A mera "falsificação" de medicamento, quando náo relacionada com um perigo concreto, náo encontra eco em termos criminais, apenas constituindo contraordenação, no âmbito do Estatuto do Medicamento (Decreto-Lei n. ${ }^{0}$ 176/2006, de 30 de Agosto, o qual, não obstante uma recente alteração em 2019, também não sofreu modificação a este propósito.

Nos termos do art. $283^{\circ}$ do CP,

1. Quem:

a) Propagar doença contagiosa;

b) Como médico ou seu empregado, enfermeiro ou empregado de laboratório, ou pessoa legalmente autorizada a elaborar exame ou registo auxiliar de diagnóstico ou tratamento médico ou cirúrgico, fornecer dados ou resultados inexactos; ou

c) Como farmacêutico ou empregado de farmácia fornecer substâncias medicinais em desacordo com o prescrito em receita médica;

e criar deste modo perigo para a vida ou perigo grave para a integridade física de outrem é punido com pena de prisão de um a oito anos.

4 J. M. Damião da Cunha, Anotação ao Art. 282º, p. 1000.

5 Susana Aires de Sousa, A Convenção Medicrime do Conselho da Europa, Cadernos da Lex Medicinae, n. ${ }^{4}$, vol. II (2019). 
2. Se o perigo referido no número anterior for criado por negligência, o agente é punido com pena de prisão até cinco anos.

3. Se a conduta referida no n. ${ }^{\circ} 1$ for praticada por negligência, o agente é punido com pena de prisão até três anos ou com pena de multa.

No que respeita ao art. $283^{\circ}$ do CP, o mesmo tem merecido maior atenção face à actual situação de pandemia e em relação ao qual mais se tem associado a saúde pública ${ }^{6}$.

Com efeito, a doença contagiosa referida na al. a), atendendo à exigência de um perigo "grave" não poderá ser uma doença contagiosa que náo tenha qualquer gravidade, dado ter de ser susceptível de produzir o perigo "grave" para a integridade física, ou seja, tem de manifestar adequação à produção do perigo. Não obstante, "o artigo abrange todo o tipo de doenças (independentemente de ser necessária a sua declaração obrigatória, de serem de origem conhecida ou desconhecida) que possam ser consideradas de contágio"7. Por seu turno, o agente terá de propagar a doença, tanto podendo tal propagaçáo ocorrer por transmissão, em que o próprio agente é portador da doença, ou por infecção, em que o agente "contamina" alimentos, água ou objectos, etc. Podem estar em causa não só doenças humanas, como também doenças comuns a homens e a animais.

A Região Administrativa Especial de Macau (RAEM), no seu Código Penal (doravante, CPM) tem, igualmente, os tipos penais de corrupção de substâncias alimentares ou medicinais (art. 2690 CPM) e de propagação de doença, alteração de análise ou receituário (art. 270 CPM), ambos com redação idêntica aos correlativos arts. $282^{\circ}$ e $283^{\circ}$ do CP e semelhante ordenação sistemática.

Todavia, a RAEM viu aprovada, após a crise sanitária SARS de 2001-2003, a Lei n. ${ }^{\circ}$ 2/2004 (Lei de prevenção, controlo e tratamento de doenças transmissíveis) ${ }^{8}$. Esta Lei, visando garantir a saúde pública e a prevenção, controlo e tratamento eficazes de doenças transmissíveis,

6 Tendo-se logo em Abril de 2020 Maria Fernanda Palma pronunciado a favor da consideração da saúde pública como bem jurídico protegido no crime de propagação de doença. Cfr. Maria Fernanda Palma, Propagação de doença contagiosa, disponível em: https://cidpcc.wordpress.com/2020/04/10/propagacao-de-doenca-contagiosa-por-maria-fernanda-palma/.

7 Cunha (1999), p. 1008.

8 Por todos, Vera Lúcia Raposo, Macau, a Luta contra a COVID-19 no Olho do Furação, Cadernos Ibero-Americanos de Direito Sanitário 2020; 9(2): p. 12 e s. 
através dos princípios da prevenção prioritária e do tratamento adequado (art. $1^{\circ}$, n. $\left.{ }^{\circ} 1\right)$, contém diversas medidas que podem ser aplicáveis em casos de surtos ou prevalência ou risco de surto ou prevalência de doença transmissível (arts. $1^{\circ}$, e $23^{\circ}$ a $25^{\circ}$ ), sendo que estabelece, para a violação dessas medidas e para a violação do preenchimento de declarações exigíveis (art. 10º ) o crime de infracção de medida sanitária preventiva.

Nos termos do art. $30^{\circ}$ da Lei n. ${ }^{\circ}$ 2/2004:

Infracção de medida sanitária preventiva

É punido com as penas seguintes, salvo se pena mais grave ao caso não couber por força de outra disposição legal:

1) Quem se recusar a preencher as declaraçôes previstas na alínea 1) do n. ${ }^{\circ} 2$ do artigo $10 .^{\circ}$ ou delas fizer constar dados falsos para se furtar às medidas previstas na presente lei ou recusar submeter-se ao exame médico previsto na alínea 3) do mesmo número, com pena de prisáo até 6 meses ou com pena de multa até 60 dias;

2) Quem náo cumprir as medidas previstas na alínea 1) do n. ${ }^{\circ} 1$ do artigo $14 .^{\circ}$, com pena de prisão até 6 meses ou com pena de multa até 60 dias;

3) Quem não cumprir as medidas previstas nas alíneas 2) ou 3) do n. ${ }^{\circ} 1$ do artigo $14 .^{\circ}$, com pena de prisão até 1 ano ou com pena de multa até 120 dias; e

4) Quem não cumprir as medidas previstas nas alíneas 1), 2) ou 5) a 9) do n. ${ }^{\circ} 1$ do artigo $25 .^{\circ}$, com pena de prisão até 2 anos ou com pena de multa até 240 dias.

No novo Código Penal de Angola? (doravante CPA) podemos também encontrar os crimes de adulteração de substâncias alimentares e medicinais (art. 286 $)^{10}$ e de propagação de doença contagiosa (art. 2870), mas, no caso do CPA, observamos uma diferença significativa face aos CP e CPM: ainda que ambos os crimes se encontrem no título dos crimes contra a segurança colectiva, no capítulo dos crimes de perigo comum, o crime do art. 2870 CPA dirige-se apenas à propagação de doença, ou seja, não faz a tipificação, no mesmo tipo, da alteração de análise ou de receituário. Outra importante diferença do CPA é o mesmo incluir especificamente o crime de contágio de doença grave

9 Aprovado pela Lei n. ${ }^{\circ}$ 38/20, de 11 de Novembro de 2020.

10 No Código Penal de Moçambique, este crime restringe-se aos géneros alimentícios (art. 224). 
(art. 206) no capítulo da colocação de pessoas em perigo, no âmbito do título dos crimes contra as pessoas.

Nos termos do art. $206^{\circ}$ do CPA:

1. Quem, com intenção de transmitir doença grave de que padece, praticar acto susceptível de contagiar outra pessoa é punido com pena de prisão até 3 anos ou com a de multa até 360 dias.

2. Se a doença se transmitir, a pena de prisão é de 6 a 10 anos.

A situação no Brasil é mais específica ainda. Com efeito, desde logo, no Código Penal brasileiro (doravante, $\mathrm{CPB}$ ) podemos encontrar um capítulo relativo aos crimes contra a saúde pública no âmbito do título dos crimes contra incolumidade pública (arts. $267^{\circ}$ e ss. CPB). Por outro lado, não obstante existir também o crime de falsificação, corrupção, adulteração ou alteração de produto destinado a fins terapêuticos ou medicinais (art. 273 CPB), encontramos no referido capítulo específico relativo aos crimes contra a saúde pública, crimes diretamente relacionados com situaçóes epidémicas, ou seja, o crime de epidemia (art. 2670 CPB), o crime de infração de medida sanitária preventiva (art. $268^{\circ} \mathrm{CPB}$ ) e ainda o crime de omissão de notificaçáo de doença (art. 269 $\mathrm{CPB}$ ).

\section{Epidemia}

Art. 267 - Causar epidemia, mediante a propagação de germes patogênicos: Pena - reclusão, de dez a quinze anos.

$\$ 1^{\circ}$ - Se do fato resulta morte, a pena é aplicada em dobro.

$\$ 2^{\circ}$ - No caso de culpa, a pena é de detenção, de um a dois anos, ou, se resulta morte, de dois a quatro anos.

Infração de medida sanitária preventiva

Art. 268 - Infringir determinação do poder público, destinada a impedir introdução ou propagaçáo de doença contagiosa:

Pena - detenção, de um mês a um ano, e multa.

Parágrafo único - A pena é aumentada de um terço, se o agente é funcionário da saúde pública ou exerce a profissão de médico, farmacêutico, dentista ou enfermeiro.

Omissão de notificação de doença

Art. 269 - Deixar o médico de denunciar à autoridade pública doença cuja notificação é compulsória:

Pena - detenção, de seis meses a dois anos, e multa. 
O crime de infração de medida sanitária preventiva, como resulta da sua redacção típica ("infringir determinação do poder público"), é uma norma penal em branco, carecendo de concretização ${ }^{11}$.

\section{- Outros crimes}

Um dos crimes que também tem conhecido forte expressão em tempos de pandemia é o crime de desobediência, previsto no art. $348^{\circ}$ do CP e também no art. $7^{\circ}$ da Lei n. ${ }^{\circ} 44 / 86$, de 30 de Setembro (Regime do Estado de Sítio e do Estado de Emergência, doravante RESEE).

No início do estado de emergência em Portugal, o Decreto n. ${ }^{\circ}$ 2-A/2020, de 20 de Março $^{12}$ começou por estabelecer um crime de desobediência específico para os casos de violação da obrigação de confinamento obrigatório (art. $3^{\circ}$ ), além da cominação, por crime de desobediência (art. 348 $\mathrm{CP}$ ), de um conjunto de outras situaçóes, maxime, o encerramento de instalaçôes e estabelecimentos, a suspensão de actividades no âmbito do comércio a retalho e da prestação de serviços (art. 32o, n.o 1, al. b), do Decreto). Este modelo foi sendo mantido pelo Decreto n. ${ }^{\circ} 2-\mathrm{B} / 2020$, de 2 de Abril (arts. $3^{\circ}$ e 43, n. ${ }^{\circ} 1$, al. d)); e Decreto n. ${ }^{\circ}$ 2-C/2020, de 17 de Abril (arts. $3^{\circ}$ e $46^{\circ}$, n. ${ }^{\circ} 1$, al. d)). O Decreto n. ${ }^{\circ} 2-\mathrm{D} / 2020$, de 20 de Abril cominou com crime de desobediência simples a violação de circulação entre os dias 1 e 3 de maio de 2020, período em que Portugal já se encontraria em estado de calamidade (art. $\left.3^{\circ}\right)$.

Com a nova declaração, em 6 de Novembro de 2020, do estado de emergência em Portugal, abdicando-se do crime de desobediência específico constante dos Decretos n. ${ }^{\circ}$ s 2-A, 2-B e 2-C, acima referidos, voltou a recorrer-se à cominação por crime de desobediência (art. $12^{\circ}$, n. ${ }^{\circ} 1$, al. b) do Decreto n.o 8/2020, de 8 de Novembro), recurso que se viria a manter nos decretos de regulamentação dos estados de emergência decretados pelo Presidente da República seguintes (Decreto n. ${ }^{\circ}$ 9/2020, de 21 de Novembro (art. 50') e Decreto n. ${ }^{\circ}$ 11/2020, de 6 de Dezembro (art. 58\%). O crime de desobediência encontra-se

11 O que veio a acontecer, p. ex., com a Lei 13.979/2020, quanto ao isolamento e à quarentena, e a Portaria n. ${ }^{\circ}$ 356/2020, do Ministério da Saúde e a Portaria Interministerial n.o 5/2020, do Ministérios da Justiça e Segurança Pública e da Saúde.

12 Que procedeu à regulação da primeira declaração de estado de emergência efectuada pelo Decreto do Presidente da República n. ${ }^{\circ}$ 14-A/2020, de 18 de Março. 
cominado, fundamentalmente, para a violação de confinamento obrigatório, para a violação da proibição de circulação na via pública e para a violação da limitação das actividades de estabelecimentos comerciais e serviços.

Podemos também encontrar o crime de desobediência no art. $312^{\circ}$ $\mathrm{CPM}$, no art. $330^{\circ} \mathrm{CPB}$, no art. $340^{\circ} \mathrm{CPA}$ ou no art. $353^{\circ}$ do Código Penal de Moçambique.

Havendo regime próprio na RAEM, o recurso ao crime de desobediência, nos termos feitos no ordenamento jurídico português, não é necessário.

Diferentemente, nos países em que não exista uma Lei como a Lei n. ${ }^{\circ}$ 2/2004 da RAEM, o recurso a esta via repressiva - mesmo quando existam crimes mais específicos para a protecção da saúde pública - tem sido o caminho seguido como forma de sancionar a violação de medidas sanitárias impostas no controlo e combate à COVID-19.

\section{- Crimes aplicáveis a fraudes na vacinação (violação plano de vacinação)}

Em termos tópicos, e estando já em curso o processo de vacinação, eventuais condutas de fraude na vacinação com vista a benefício do próprio ou de terceiro quanto à antecipaçáo da toma da vacina face ao previsto no Plano de Vacinação respectivo, poderão ser enquadráveis em crimes como o abuso de poder ou o recebimento indevido de vantagem.

\subsection{Extraordinária}

Como referido no ponto anterior, a maioria dos ordenamentos jurídicos já dispunham de crimes relacionados com a saúde pública ou o crime de desobediência.

Pode, contudo, apontar-se o caso da incriminação de um crime de desobediência específico para a violação do confinamento obrigatório (inicialmente introduzido pelo art. $3^{\circ}$ do Decreto n. ${ }^{\circ} 2-\mathrm{A} / 2020$, de 20 de Março), entretanto afastado e enquadrado no crime de desobediência previsto no art. $348^{\circ}$ do $\mathrm{CP}^{13}$.

13 E no RESEE, para o respectivo âmbito de aplicação. 


\section{Outra legislação sancionatória}

\subsection{Contraordenacional}

O regime contraordenacional para as situaçóes de calamidade, contingência e alerta ${ }^{14}$ é estabelecido pelo Decreto-Lei n. ${ }^{\circ}$ 28-B/2020, de 26 de Junho ${ }^{15}$, visando "a criação de um regime sancionatório que assegure o escrupuloso cumprimento, pela população, das medidas que são indispensáveis à contenção da infecção".

Em termos estruturais, a lei estabelece um conjunto de deveres - desde a obrigatoriedade do uso da máscara, às regras de ocupação de estabelecimentos e distanciamento físico - no seu art. $2^{\circ}$, prevendo, depois, no art. $3^{\circ}$, as coimas para o incumprimento dos deveres elencados no art. $2^{\circ}$.

Actualmente, a violação da maioria dos deveres é sancionada com coima de 100 a 500 euros para pessoas singulares e de 1000 a 10000 euros para pessoas colectivas, sendo estes montantes elevados para o dobro durante o estado de emergência (art. $\left.3^{\circ}-A\right)$. O montante da coima é agravado em situação de incumprimento de regras aplicáveis ao tráfego aéreo e aos aeroportos.

\section{Tendências}

Em termos sancionatórios, podemos identificar duas tendências. Por um lado, o recurso ao crime de desobediência enquanto meio repressivo penal principal para a violação das medidas sanitárias. Podemos encontrar esta tendência primordialmente nos países que recorreram a regimes excepcionais.

Por outro lado, o privilegiamento do cumprimento das medidas sanitárias impostas através da via não penal. Considerando o caso português, p. ex., ainda que continue a existir o recurso ao crime de desobediência, o decurso do tempo de duração da crise sanitária levou à aprovação de um regime contraordenacional próprio para cumprimento, pela população, das medidas impostas (Decreto-Lei n. ${ }^{\circ}$ 28-B/2020, de 26 de Junho).

14 Declaradas ao abrigo da Lei n. ${ }^{\circ}$ 27/2006, de 3 de Julho (Lei de Bases da Protecção Civil).

15 Alterado já cinco vezes, a última das quais pelo Decreto-Lei n. ${ }^{\circ} 8-A / 2021$, de 22 de Janeiro. 


\section{Aplicaçáo}

Em termos de relevância, o crime de desobediência tem sido, em termos penais, o tipo penal que maior aplicação tem conhecido, desde logo, como fundamento para a realização de detençôes. A título ilustrativo, refira-se que a Polícia de Segurança Pública portuguesa realizou, entre o início da pandemia, em Março de 2020, e Janeiro de 2021, 438 detençôes por desobediência, no âmbito da fiscalização das medidas restritivas impostas pelo Governo no combate à COVID-19 16 .

O crime de desobediência específico criado no início da pandemia pelo Decreto n. ${ }^{\circ} 2-\mathrm{A} / 2020$, de 20 de Março - logo criticado ${ }^{17}$ - foi considerado inconstitucional (inconstitucionalidade orgânica) pelo Tribunal da Relaçấo de Guimarães, em acórdão de 9 de Novembro de $2020^{18}$.

Pode ler-se no aresto que, sendo a criação de tipos penais matéria de reserva relativa de competência da Assembleia da República, nos termos do art. $165^{\circ}$, n. ${ }^{\circ} 1$, al. c), da Constituição da República Portuguesa, o aludido Decreto n. ${ }^{\circ}$ 2-A/2020, de 20 de Março, "ao definir um novo tipo de crime invade a competência legislativa que lhe não cabe, o que determina que o n. ${ }^{\circ} 2$ do art. $3^{\circ}$ do referido Decreto esteja ferido de inconstitucionalidade orgânica". Na verdade, uma norma penal como o é o crime de desobediência aqui em causa no Decreto - tem de revestir a forma de lei $^{19}$. Ademais, o RESEE torna claro, no seu art. $19^{\circ}$, n. ${ }^{\circ} 7$, que o estado de emergência náo pode colocar em causa as regras constitucionais atinentes à competência e funcionamento dos

16 Conforme noticiado pela RTP: https:/www.rtp.pt/noticias/pais/psp-fez-438-detencoes-em-portugal-desde-marco-por-violacao-de-regras-de-confinamento_ n1290209.

17 Alexandre Au-Yong Oliveira et al., Jurisdição Penal e Processual Penal, in: CEJ (Org.), Estado de Emergência - COVID-19 - Implicaçôes na Justiça, Lisboa, 2020, p. 429 e s., p. 432 e s.

18 Disponível em: http://www.dgsi.pt/jtrg.nsf/86c25a698e4e7cb7802579ec004 d3832/4bf68cafb74dfa02802-58639005815e9?OpenDocument.

19 Lei da Assembleia da República ou Decreto-Lei autorizado, como refere o art. 165, n. ${ }^{\circ}$ 1, al. c), da CRP. Cfr. José de Faria Costa, Direito Penal, Lisboa: Imprensa Nacional casa da Moeda, 2017, p. $138^{\circ}$ e s.; especificamente quanto a este Decreto, Alexandra Vilela, COVID-19 e o Direito Penal, in: Inês Fernandes Godinho/Miguel Osório de Castro (Eds.), COVID 19 e o Direito, Lisboa: Ediçôes Universitárias Lusófonas, 2020, p. 127 e s., p. 134. 
órgãos de soberania. Deste modo, não poderia, como o fez, o Decreto n. ${ }^{\circ} 2-\mathrm{A} / 2020$, de 20 de Março ter criado um crime de desobediência específico. Razão, aliás, porque deixou o Governo de prever tal crime específico em ulteriores Decretos.

Esta questão é ilustrativa de uma tendência inicial mais repressiva, entretanto amenizada, também, pela criação do regime contraordenacional do Decreto-Lei n. ${ }^{\circ} 28-\mathrm{B} / 2020$, de 26 de Junho.

\section{Principais conclusóes}

Em termos de legislação penal vigente, maxime, o Código Penal respectivo, pode observar-se uma grande semelhança entre os diferentes países e a RAEM quanto aos crimes de corrupção de substâncias medicinais e de propagação de doença, além da ordenação destes crimes como crimes de perigo comum e não como especificamente contra a saúde pública. Diferente é a situação do $\mathrm{CPB}$, onde já encontramos não só a especificação de um capítulo de crimes contra a saúde pública, como também tipos legais de crime concretamente orientados para situaçóes epidémicas e pandémicas. De notar também a incriminaçáo contida no art. $30^{\circ}$ da Lei n. ${ }^{\circ} 2 / 2004$ da RAEM, especificamente orientada para estas situaçóes.

Outro ponto bastante interessante, em termos de direito sancionatório penal, é o recurso, por defeito, ao crime de desobediência, como modo de repressáo do desrespeito de medidas de prevenção e combate à pandemia implementadas em estados de excepção. Com efeito, encontramos, em países não apetrechados com uma lei como a Lei n. ${ }^{\circ}$ 2/2004 da RAEM, em que tem sido feito recurso a estados de excepção - v.g., estados de emergência - a cominação com o crime de desobediência das diversas violaçốes de deveres impostos aos cidadáos, aumentando significativamente a relevância e o impacto desta incriminação em contexto pandémico.

Por outro lado, e ainda a propósito deste crime, tendo mesmo a sua inserção no CP sido, ao tempo, contestada ${ }^{20}$, não deixa de ser esclarecedor que a via repressiva inicialmente acentuada em Portugal - com a

20 Cfr. Cristina Líbano Monteiro, Anotação ao Art. 348º, in: Jorge de Figueiredo Dias (Dir.), Comentário Conimbricense do Código Penal, Tomo III, Coimbra: Coimbra Editora, 2001, p. 349 e s., p. 350; Alexandra Vilela (2020), p. 133. 
criação de um crime de desobediência específico - levante o véu sobre os perigos do recurso a estados de excepção ${ }^{21}$.

Daí que devam ser acentuadas as vantagens, tomando-se como referência o regime da RAEM, do recurso a outras normas e de um melhor enquadramento sancionatório para crises de saúde pública provocadas por epidemias ou pandemias sanitárias que, segundo diversos especialistas, serão, de futuro, cada vez mais frequentes.

21 Mesmo que, no contexto da RESEE, não possa, em caso algum ser colocado em causa o princípio da separação de poderes. 


\section{DIREITOS DOS DOENTES EM CONTEXTO DE PANDEMIA}

André Dias Pereira, Ana Elisabete Ferreira e Carla Barbosa

\section{Introduçáo}

O surgimento e evoluir da pandemia trouxe desafios que no início de 2020 seriam inimagináveis. Como reação às necessidades que surgiram, as entidades governativas tiveram de lançar mão de instrumentos legalmente estabelecidos que permitiram a adoção de certas medidas. O estado de emergência previsto na Constituição da República Portuguesa só pode ser declarado nos casos de agressão efetiva ou iminente por forças estrangeiras, de grave ameaça ou perturbação da ordem constitucional democrática ou de calamidade pública. É esta última realidade que vivemos atualmente.

Contudo, o decretar do estado de emergência em caso algum pode afetar os direitos à vida, à integridade pessoal, à identidade pessoal, à capacidade civil e à cidadania, à não retroatividade da lei criminal, às garantias de defesa dos arguidos e à liberdade de consciência e de religiáo. Vejamos, no entanto, como a pandemia e as medidas adotadas afetaram os direitos dos doentes em contexto de pandemia.

\section{a) Coordenadas do Sistema de Saúde português}

Pode afirmar-se que Portugal tem um alto padrão de serviços de saúde. O sistema de saúde português ficou em $13 .^{\circ}$ lugar, em 2018, no Euro Health Consumer Index (EHCI), subindo sete posiçóes em relaçáo a 2015 (e afastando-se definitivamente do 25. ${ }^{\circ}$ lugar, em que se encontrava em 2012), para ficar à frente do Reino Unido e da Espanha, pela primeira vez. Portugal teve um desempenho particularmente bom em 
classificaçóes de qualidade-preço. Já no World Health Report, organizado pela Organizaçáo Mundial de Saúde, publicado em 2020, relativo ao ano de 2019, encontra-se na 12 . $^{\text {a }}$ posiçãa ${ }^{1}$.

De acordo com os dados da Pordata de 2019, o nosso país gasta atualmente cerca de $9,5 \%$ do seu PIB em cuidados de saúde. De acordo com o European Observatory of Health Systems and Policies, 2019, embora tenha existido um aumento com as despesas em saúde quando feita a comparação com o período da crise económica, em 2017, Portugal gastou 2029 euros per capita em cuidados de saúde (9\% do PIB), que é cerca de um terço menos do que a média da UE (2 884 euros). Os pagamentos diretos tornaram-se a segunda maior fonte de receita, atingindo $27,5 \%$ das despesas totais com saúde. Como parte do reforço dos cuidados primários, o Governo assumiu como medidas necessárias o aumento de médicos de clínica geral para o Serviço Nacional de Saúde, o aumento de utentes com acesso a médicos de clínica geral e familiar (os vulgarmente designados médicos de família) e dar aos municípios um papel mais relevante e interventivo na gestão dos cuidados de saúde primários ${ }^{2}$.

No contexto do perfil de saúde, e de acordo com dados do Observatório da OCDE de 2019, Portugal demonstra eficácia no tratamento de patologias crónicas pelos cuidados primários e de ambulatório, com taxas de admissão evitáveis bastante abaixo da média europeia, e apresenta um alto desempenho no tratamento de certas doenças, como o cancro, registando taxas de sobrevivência acima dos restantes estados-membros.

As maiores fragilidades que lhe são apontadas não têm, contudo, sofrido alteraçóes importantes nos últimos cinco anos, mantendo uma infeliz continuidade: o nosso país precisa de diminuir as disparidades socioeconómicas e de género para alterar o perfil de saúde dos cidadãos; precisa de diminuir o impacto de fatores de risco como a obesidade e fatores comportamentais (como o consumo excessivo de álcool e de tabaco); demanda a diminuição das listas de espera para consulta e cirurgia programadas; e necessita de uma melhor e mais intensa alocação de recursos humanos.

1 Relatório completo e tabelas de estatísticas disponíveis em https://www.who. int/data/gho/publications/world-health-statistics

2 Relatório disponível em https:/ec.europa.eu/health/sites/health/files/state/ docs/2019_chp_pt_english.pdf 
Em 1976, a Constituição Portuguesa proclamou o direito dos cidadãos à proteção da saúde através da "criação de um Serviço Nacional de Saúde universal e gratuito" (art. 64. ${ }^{\circ}$ ) e, em 1979, a Lei n. $56 / 79$, de 15 de setembro, cria o Serviço Nacional de Saúde (SNS) como um sistema de saúde universal e geral, gratuito no ponto de uso.

Os ventos da abertura à economia de mercado e ao neoliberalismo chegaram a Portugal no final dos anos 80, afetando também o desenho da política de saúde. Assim, uma revisão da Constituição, em 1989, veio eliminar a total gratuitidade, ao admitir um SNS "tendencialmente gratuito" e a Lei de Bases da Saúde foi reformulada, em 1990, com maior abertura ao mercado privado de saúde. Ainda assim, a estrutura fundamental do sistema baseado na prestação pública no SNS - manteve-se, embora fosse frequente o acesso a consultas em consultórios privados e o pagamento do próprio bolso ("out-of-pocket").

Todavia, nos últimos 20 anos tem sido notória a emergência de fortes grupos privados de saúde, alguns dos quais, estrangeiros, que em grande medida assentam a sua faturação em seguros privados (planos de saúde) subscritos por empresas e por famílias, na ADSE (plano público de saúde limitado aos trabalhadores em funçôes públicas) e outros subsistemas de saúde e em prestaçóes do sistema SIGIC (Sistema Integrado de Gestão de Inscritos para Cirurgia), que visa combater as listas de espera em cirurgias.

Assim, podemos constatar que o sistema de saúde português tem um carácter misto, com uma forte presença do sistema público (SNS), mas com mais de $20 \%$ da população a recorrer, em grande medida, ao sistema privado e social. Assim, o sistema de saúde português é caracterizado por três sistemas coexistentes e sobrepostos: o SNS universal; regimes especiais de seguro de saúde para determinadas profissóes ou setores (por exemplo, funcionários públicos, empregados em bancos e companhias de seguros), denominados subsistemas de saúde; e seguro de saúde voluntário privado.

Assim, em Portugal existe um sistema de saúde misto, com diferentes modelos de pagamento, isto é, um modelo baseado no Serviço Nacional de Saúde (SNS) financiado através do Orçamento do Estado; um modelo baseado no seguro social financiado por fundos de saúde de matriz profissional; um modelo baseado no seguro 
voluntário financiado individualmente e um modelo baseado em pagamentos diretos ${ }^{3}$.

Em Portugal, o sistema de saúde inclui prestadores públicos, privados e sociais. O SNS tem especial relevância porque tem um carácter universal. Como tal, melhorar a eficiência e a eficácia do SNS tem estado na base de um conjunto vasto de medidas e reformas que foram implementadas nos últimos anos.

O Ministério da Saúde é responsável pela alocação de recursos para o SNS. O orçamento global para o SNS é distribuído pelas várias instituiçóes com base em despesas históricas. Mais recentemente, métodos de pagamento foram introduzidos para cobrir os custos gerais de algumas patologias. A área da oncologia tem um modelo de atenção próprio, constituído por três centros altamente especializados (os Institutos Portugueses de Oncologia Francisco Gentil (IPO)), localizados nas cidades de Lisboa, Porto e Coimbra, e que cobrem toda a área geográfica de Portugal, complementados pela prestação de cuidados em hospitais gerais.

A prestação de Cuidados Continuados e de Cuidados Paliativos está também organizada em redes específicas, articuladas entre os Ministérios da Saúde e da Segurança Social, e com um impulso muito importante do setor social da saúde, em particular das IPSS - Instituiçóes Particulares de Solidariedade Social e das Misericórdias.

\section{b) A participação dos Doentes nas Decisóes de Saúde}

No que respeita à democracia sanitária, e ao contrário do que acontece noutros países da Europa, em Portugal os doentes não têm, genericamente, assento nos conselhos de administração ou de direção dos hospitais, que são formados, em grande medida, por profissionais de saúde e da área da gestão. A democracia sanitária e a flexibilização da relação-médico paciente ficam, assim, prejudicadas, aspeto só menorizado pelo facto de os doentes constituírem associaçóes privadas que promovem o diálogo com as entidades de saúde em nome coletivo.

O associativismo e a constituição de grupos informais de representação e participação na saúde encontram amplo respaldo no nosso

3 Sobre o sistema de saúde português vide SIMÓES, Jorge, CORREIA DE CAMPO, António, O Percurso da Saúde: Portugal na Europa, Almedina, 2011. 
sistema jurídico, e a Lei de Bases da Saúde, de acordo com a nossa Constituição, prevê expressamente o direito dos cidadãos a intervir nos processos de tomada de decisão em saúde e na gestão participada das instituições do SNS.

Várias organizaçóes e entidades internacionais, entres elas o European Patients' Forum (EPF), a Organização Mundial de Saúde (OMS) e a Organização para a Cooperação e Desenvolvimento Económico (OCDE) defendem a participação pública no âmbito da saúde.

A reforma realizada em França, designadamente, a partir de 2002, operou com eficácia uma resposta a estes desafios, colocando a primazia na dimensão da démocratie sanitaire, sendo os poderes coletivos dos doentes uma das dimensóes mais relevantes. Com efeito, o artigo L1114-1 do Código de Saúde Pública francês passou a prever, designadamente, que as associaçôes, regularmente constituídas, com uma atividade no domínio da qualidade da saúde e assistência ao paciente, possam ser aprovadas por autoridade administrativa competente a nível regional ou nacional para representar os utentes, na direção ou administração das unidades de saúde, ou autoridades de saúde pública.

Os representantes dos utentes têm direito a formação para facilitar o exercício deste mandato. Repare-se que náo se trata de um papel meramente consultivo, mas, efetivamente, de participar ativamente e em pé de igualdade com gestores, diretores e administradores na definição do funcionamento. É a forma de assegurar uma participação efetiva dos doentes na gestão da saúde, através dos seus participantes.

Em Portugal não se tem verificado uma preocupação específica e concretizada no sistema jurídico com esta questão, e até há pouco não era claro qualquer papel importante dos doentes na gestão e administração de serviços de saúde, ou no quadro institucional de formação dos profissionais de saúde.

A Carta para a Participação Pública em Saúde, aprovada pela Lei n. ${ }^{\circ}$ 108/2019, de 9 de setembro de 2019, pretendeu alterar este estado de coisas. Nasceu com o objetivo de fomentar a participação por parte das pessoas, com ou sem doença e seus representantes, nas decisóes que afetam a saúde da população, e incentivar a tomada de decisão em saúde assente numa ampla participação pública, consolidando a participação pública a nível político e dos diferentes órgãos e entidades do Estado, em Portugal, através do aprofundamento dos processos de 
participação já existentes e da criação de novos espaços e mecanismos participativos $^{4}$.

Ora, o que agora se impóe verificar e assentar são, precisamente, os mecanismos existentes de participação dos doentes e dos seus representantes, e qual o seu impacto efetivo nas políticas da saúde. De acordo com a Carta, a participação pública das pessoas com ou sem doença e seus representantes abrange, nomeadamente, as seguintes áreas: plano Nacional de Saúde e programas de saúde; gestão do SNS, incluindo recursos humanos, materiais e financeiros, e organização da prestação dos cuidados de saúde, através dos agrupamento de centros de saúde e dos hospitais; orçamento do Estado para a saúde; avaliaçáo de tecnologias de saúde; avaliação da qualidade em saúde; normas e orientaçóes; ética e investigação em saúde; direitos das pessoas com ou sem doença e seus representantes. Há vasta evidência internacional sobre a importância da operacionalidade democrática e da representação na gestão da saúde que é necessário comparar e ajustar no nosso sistema.

Se no conceito de democracia sanitária emerge como estrutural uma dimensão individual, traduzível no apoio à decisão e no empoderamento do doente, designadamente, pelo verdadeiro respeito pelo direito à informaçáo e ao esclarecimento e pelo direito de acesso e controlo da sua informação de saúde, é de realçar que deve ser reforçada a dimensão coletiva, no sentido da efetivação dos direitos dos

4 A Carta para a Participação Pública em Saúde contribui para: promover e defender os direitos das pessoas com ou sem doença, em especial no que respeita à proteçâo da saúde, da informação e da participação; informar as entidades públicas sobre as prioridades, necessidades e preocupaçóes das pessoas com ou sem doença e seus representantes; tornar as políticas de saúde mais eficazes e, consequentemente, obter melhores resultados em saúde; promover a transparência das decisóes e a prestação de contas por parte de quem decide; aproximar o Estado e a sociedade civil, aprofundando o diálogo e a interação regular entre ambos; legitimar as decisóes sobre a avaliação custo -efetividade e os dilemas éticos colocados pelas inovaçóes tecnológicas.

A participação pública em saúde deve assentar nos seguintes princípios: reconhecimento da participação pública como direito das pessoas com ou sem doença e seus representantes; reconhecimento das pessoas com ou sem doença e seus representantes como parceiros nos processos de tomada de decisão; reconhecimento da importância do conhecimento e da experiência específicos da pessoa com ou sem doença; autonomia e independência das pessoas com ou sem doença e seus representantes nos processos; transparência e divulgação pública dos processos participativos; criaçáo das condiçôes necessárias à participação; complementaridade e integração entre instituiçôes e mecanismos da democracia representativa e da democracia participativa. 
doentes, através da criação e legitimação das associações de doentes, e das ONG's, em geral, conduzindo consequentemente a um reforço da sociedade civil.

\section{c) Soluçóes e oclusóes do sistema, em contexto de pandemia}

Nestas diferentes dimensōes - 1) a qualidade da prestação de cuidados de saúde e 2) a promoção da participação dos doentes nas políticas e decisôes de saúde - o sistema de saúde português resultou gravemente empobrecido no contexto da pandemia.

O SNS aumentou muito significativamente a sua capacidade de prestar cuidados de saúde, aumentando e continuando a aumentar, em centenas, as camas, os profissionais de saúde, os meios complementares de diagnóstico e terapêutica e os dispositivos médicos, num crescendo inigualável. A resposta oferecida pelo SNS revelou-se bastante robusta - em celeridade, adequação, qualidade e quantidade. Parece-nos que mais robusta do que seria uma resposta privada no mesmo contexto, dadas as exigências de rápida decisão e coordenação que se exigiu nos picos pandémicos. Porém, as fragilidades do sistema acentuaram-se até porque a disponibilidade de recursos quer falemos de meios humanos quer de equipamentos não é elástica e a procura, essa, por sua vez, não para de aumentar.

\section{Testagem}

No que respeita à testagem, o Ministério da Saúde organizou e monitorizou um sistema de testes, gratuitos para o utilizador, dentro do quadro de indicaçôes da Direção Geral de Saúde. Assim, todas as pessoas que desenvolvam quadro clínico sugestivo de infeção respiratória aguda com pelo menos um dos seguintes sintomas: tosse de novo ou agravamento da tosse habitual ou associada a cefaleias ou mialgias, ou febre: temperatura $\geq 38.0^{\circ} \mathrm{C}$ sem outra causa atribuível, ou dificuldade respiratória/dispneia, sem outra causa atribuível perda total ou parcial do olfato (anosmia), enfraquecimento do paladar (ageusia) e perturbação ou diminuição do paladar (disgeusia) de início súbito, são considerados suspeitos de COVID-19, e têm indicação para teste (gratuito), nos centros de referência. Grande parte desta monitorização está a cargo da Linha Saúde 24, através da qual todos os cidadãos podem 
obter informação sobre o encaminhamento adequado da sua situação. Contudo, o teste laboratorial para SARS-CoV-2 poderá ser pedido (só assim será gratuito) pelo médico das equipas das unidades de saúde familiares (USF) / unidade de cuidados de saúde personalizados (UCSP) para os doentes com indicação para vigilância clínica e isolamento no domicílio, de forma remota através da plataforma Exames Sem Papel, pelo médico das equipas das ADR-C (áreas dedicadas a doentes respiratórios nos cuidados de saúde primários) ou ADR-SU (áreas dedicadas a doentes respiratórios nas unidades hospitalares) ou por qualquer médico que durante a avaliação clínica considere a suspeita de COVID-19, excecionalmente e de forma automática pelos profissionais de saúde do SNS24 que façam triagem clínica, através da geração da requisição de testes, mediante aplicação de algoritmo aprovado pela Direção-Geral da Saúde.

O teste de referência para o diagnóstico da COVID-19 é o Teste Molecular de Amplificação de Ácidos Nucleicos (TAAN). Não obstante, em situação de surto, são realizados testes rápidos de antigénio, para reduzir o tempo de obtenção de resultados e implementar as medidas necessárias. Os testes utilizados em Portugal são os recomendados pelas autoridades de saúde internacionais, quer pelo Centro Europeu de Controlo de Doenças (ECDC), quer pela Organização Mundial de Saúde (OMS).

Os doentes sem sintomas de COVID-19 não têm, em princípio, indicação expressa para fazer o teste gratuito, de acordo com o procedimento definido pela Direção Geral de Saúde. Poderão fazê-lo por sua iniciativa, ou no âmbito das instituiçóes onde prestem habitualmente a sua atividade profissional, quando estas promovam o rastreio. No âmbito do setor privado de saúde existe ampla oferta de testagem, com diferentes procedimentos e preços.

\section{Tratamento}

O tratamento da COVID-19 é gratuito, no âmbito do SNS. O internamento, os exames complementares de diagnóstico e a terapêutica em contexto hospitalar é universal e gratuita. Quando não haja necessidade de internamento, os medicamentos adquiridos em farmácia comunitária respeitam os regimes geral e especiais de comparticipação do Estado no preço dos medicamentos. 
Considerando a escassez de meios do SNS foi contratualizado com unidades hospitalares privadas o tratamento de alguns doentes que, numa situação normal, seriam acompanhados no âmbito do SNS.

\section{Vacinação}

No que concerne à vacinação, toda a população portuguesa poderá ser vacinada, de forma totalmente gratuita, desde que seja elegível de acordo com as indicaçóes clínicas aprovadas para cada vacina na Uniáo Europeia. Contudo, foram definidos grupos prioritários, por estarem mais vulneráveis à COVID-19.

Segundo o plano de vacinação, que pode sofrer alteraçóes em função da evolução do conhecimento científico e das indicações e contraindicaçôes que venham a ser aprovadas pela Agência Europeia de Medicamentos, a estratégia de vacinação será a seguinte: ${ }^{5}$

- Fase 1, a partir de dezembro de 2020:

- Profissionais de saúde envolvidos na prestaçáo de cuidados a doentes

- Profissionais das forças armadas, forças de segurança e serviços críticos

- Profissionais e residentes em Estruturas Residenciais para Pessoas Idosas (ERPI) e instituiçóes similares

- Profissionais e utentes da Rede Nacional de Cuidados Continuados Integrados (RNCCI).

A partir de fevereiro de 2021:

- Pessoas com 80 ou mais anos de idade. ${ }^{6}$

- Pessoas de idade $\geq 50$ anos, com pelo menos uma das seguintes patologias:

- Insuficiência cardíaca

- Doença coronária

5 Cf. https://covid19.min-saude.pt/vacinacao/

6 Foi importante a participação empenhada de um grupo de cidadãos, em que se inclui o primeiro signatário deste texto, no sentido de defender o alargamento da prioridade aos cidadãos com mais de 80 anos. Cf. Carta Aberta sobre os critérios para vacinação prioritária no Plano de Vacinação contra a covid-19, in Público, 26 de janeiro de 2021: https:/www.publico.pt/2021/01/26/sociedade/opiniao/carta-aberta-criterios-vacinacao-prioritaria-plano-vacinacao-covid19-1947843 
- Insuficiência renal (Taxa de Filtração Glomerular $<60 \mathrm{ml} / \mathrm{min}$ )

- (DPOC) ou doença respiratória crónica sob suporte ventilatório e/ou oxigenoterapia de longa duração

- Fase 2, a partir de abril de 2021:

- Pessoas de idade $\geq 65$ anos (que náo tenham sido vacinadas previamente)

- Pessoas entre os 50 e os 64 anos de idade, inclusive, com pelo menos uma das seguintes patologias:

- Diabetes

- Neoplasia maligna ativa

- Doença renal crónica (Taxa de Filtração Glomerular > 60ml/ $\min )$

- Insuficiência hepática

- Hipertensão arterial

- Obesidade

- Outras patologias com menor prevalência que poderão ser definidas posteriormente, em funçáo do conhecimento científico

- Fase 3, em data a determinar após a conclusão da segunda fase:

- Toda a restante população elegível, que poderá ser igualmente priorizada.

\section{d) Articulação entre o Sistema de saúde e o Sistema de Segurrança social}

A crise pandémica acarreta graves consequências socioeconómicas, diminuindo a produtividade e os rendimentos das famílias, e aumentando o desemprego e as despesas quotidianas. Portugal criou um conjunto de apoios «ad hoc» para minimizar estes efeitos.

\section{Para os empregadores}

Através da Segurança Social, para as entidades empregadoras foram criadas as seguintes medidas de apoio ao emprego:

- Layoff Simplificado (Medida Extraordinária de Apoio à Manutençáo dos Contratos de Trabalho)

- Apoio à Retoma (Apoio Extraordinário à Retoma Progressiva de Atividade) 
No primeiro trimestre de 2021, as entidades empregadoras beneficiam da suspensão de execuções por dívidas à segurança social e da suspensão dos planos prestacionais em curso. Beneficiam também do diferimento de obrigaçóes contributivas relativas aos meses de novembro e dezembro de 2020 .

\section{Para os traballhadores por conta de outrem}

Através da Segurança Social, os trabalhadores por conta de outrem, incluindo membros de órgãos estatutários e trabalhadores do serviço doméstico, mantém o acesso às medidas extraordinárias de proteção social:

- Subsídio por doença por Isolamento Profilático

- Subsídio por doença por Covid-19

- Subsídio por doença por Covid-19 de trabalhadores do Sector da Saúde

- Assistência a filho ou neto por Isolamento Profilático

A medida de Assistência a Filho ou Neto por Isolamento Profilático é aplicável aos trabalhadores que não possam exercer a sua atividade por motivos de assistência a filhos ou outros dependentes a cargo, menores de 12 anos, ou com deficiência ou doença crónica independentemente da idade, em situação de isolamento profilático, certificado pelo Delegado de Saúde ou de doença por COVID-19. Tem direito a subsídio por assistência a filho, de valor correspondente a $100 \%$ da remuneração de referência líquida, tendo como limite mínimo $65 \%$ da remuneração ilíquida. Este valor está em vigor desde 01 de abril de 2020.

Caso se trate de assistência a neto, o valor do subsídio corresponde a $65 \%$ da remuneração de referência. $\mathrm{O}$ valor da remuneração de referência líquida obtém-se pela dedução, ao valor ilíquido da remuneração de referência, da taxa contributiva aplicável ao beneficiário e da taxa de retenção do imposto sobre rendimento das pessoas singulares (IRS).

Foi também efetuado um trabalho de comunicação em larga escala, no sentido de informar os trabalhadores acerca dos seus direitos sociais, designadamente através de cartazes, como este: 


\section{COVID-19 | Se faltar ao trabalho, como proceder?}

Se for obrigado a ficar em casa devido ao novo Coronavírus poderá necessitar de um documento que comprove a sua situação clínica, justifique as suas faltas e possibilite a sua remuneração.

Saiba como deve proceder e quem o pode ajudar.

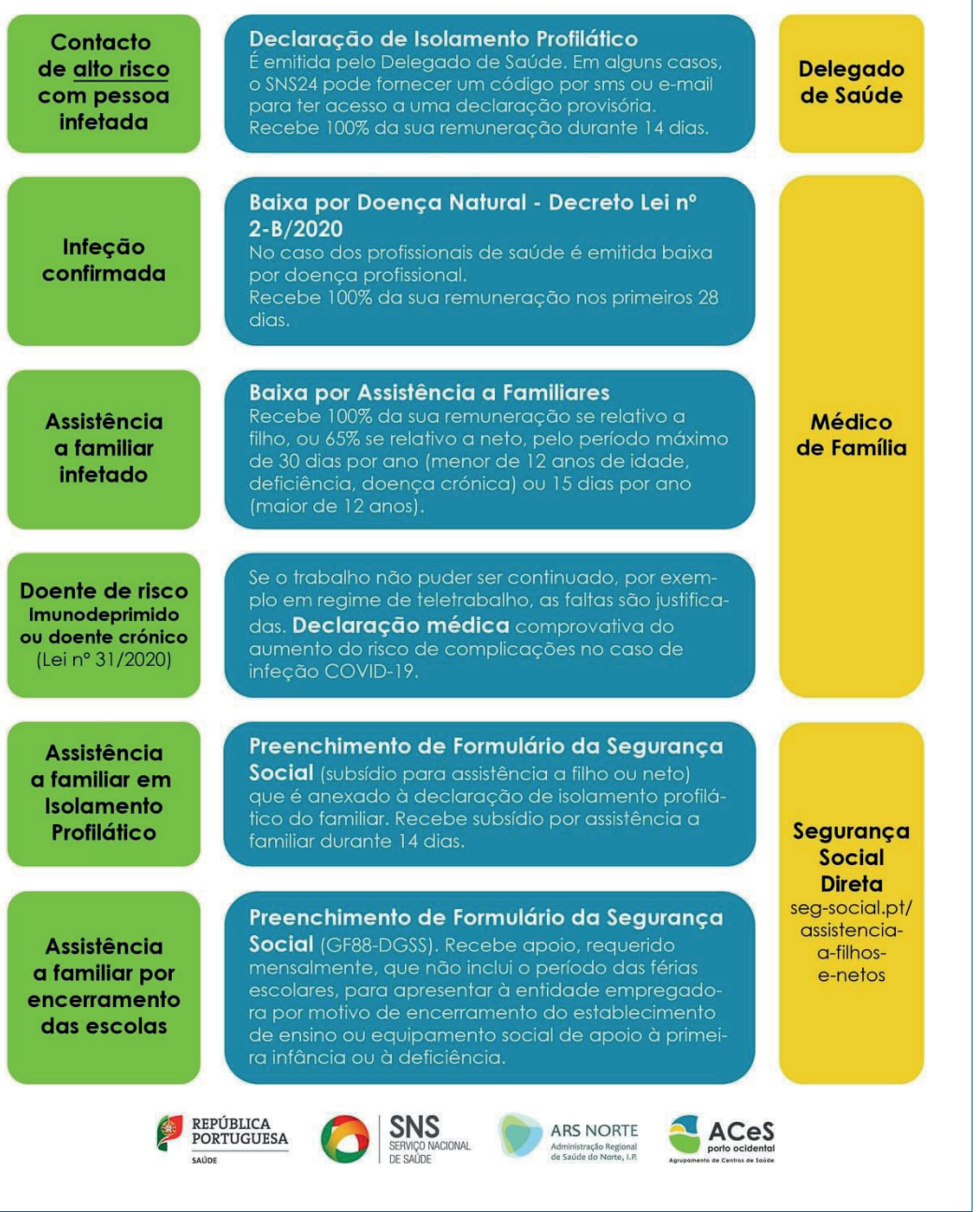

Fonte: ARS Norte

\section{Para os traballhadores independentes}

Providenciado pela Segurança Social, e destinado aos trabalhadores independentes, incluindo empresários em nome individual, sujeitos à suspensão de atividades ou encerramento de instalaçóes e 
estabelecimentos por determinação legislativa ou administrativa de fonte governamental, no estado de emergência, foram criados diferentes apoios, designadamente, as seguintes medidas de apoio ao emprego:

- Apoio Extraordinário à redução da atividade económica de trabalhador independente

- Medida Extraordinária de Incentivo à Atividade Profissional

- Apoio à Desproteção Social

\section{Para os Equipamentos Sociais e de Saúde}

Através do IEFP - Instituto do Emprego e da Formação Profissional - foi criado o Programa de Apoio ao Reforço de Emergência de Equipamentos Sociais e de Saúde, com o Reforço de Emergência de Equipamentos Sociais e de Saúde (MAREES), uma medida temporária e excecional, que consiste no apoio à realização de trabalho socialmente necessário, para assegurar a capacidade de resposta das instituiçóes públicas e do setor solidário com atividade na área social e da saúde, durante a pandemia da doença COVID-19.

Esta medida teve por objetivo contribuir para assegurar a capacidade de resposta das instituiçóes públicas e do setor solidário com atividade na área social e da saúde, nomeadamente serviços de saúde, hospitais, lares ou estruturas residenciais para pessoas idosas e pessoas com deficiência e incapacidade; promover a empregabilidade de pessoas em situação de desemprego, preservando e melhorando as suas competências socioprofissionais, através da manutenção do contacto com o mercado de trabalho; e possibilitar uma melhoria dos rendimentos dos desempregados ou dos trabalhadores com contrato de trabalho suspenso, horário reduzido ou com contrato de trabalho a tempo parcial.

Tem como destinatários os desempregados beneficiários de subsídio de desemprego, ou sem subsídio de desemprego, trabalhadores com contrato de trabalho suspenso ou horário de trabalho reduzido, trabalhadores com contratos de trabalho a tempo parcial, e estudantes, designadamente do ensino superior, bem como formandos, preferencialmente de áreas relacionadas com os projetos, com idade náo inferior a 18 anos. 


\section{e) Efeitos nos Direitos dos Doentes}

No contexto da pandemia o Governo emitiu Diretrizes, através do Ministério da Saúde, a suspender atividade programada e não prioritária. O último desses diplomas, o Despacho n. ${ }^{\circ}$ 574-A/2021, atualmente em vigor, determina que estabelecimentos hospitalares do Serviço Nacional de Saúde (SNS) passem os seus Planos de Contingência para o nível máximo e suspendam a atividade assistencial programada náo urgente que possa reverter em reforço de cuidados ao doente crítico.

A referida medida é justificada com o surgimento e a propagação do vírus SARS-CoV-2 em Portugal o que determinou a necessidade de assegurar a prevenção, contenção, mitigação e tratamento da COVID-19, através da adoção de um conjunto de medidas excecionais e temporárias de resposta à pandemia. Em Janeiro de 2021, data da publicação do referido diploma, Portugal registava uma taxa de notificação acumulada a 14 dias acima dos 900 casos por 100000 habitantes e um número médio de casos secundários resultantes de um caso infetado, medido em função do tempo, $\mathrm{R}(\mathrm{t})$, superior a 1 .

Estes fatores colocam o sistema de saúde, e em particular o Serviço Nacional de Saúde (SNS), sob elevada pressão, em especial no internamento hospitalar (internamento em enfermaria e internamento em cuidados intensivos ambos com taxas de ocupaçáo, em janeiro, que se situam entre $85 \%$ e $96 \%$ ). Em janeiro de 2021 foi atingido o número máximo de internamentos por COVID-19 nas instituições do SNS, desde o início da pandemia. Com o confinamento rigoroso de fevereiro e março, a situação pandémica ficou controlada e a saúde pública foi salvaguardada.

Considerada a atual situação epidemiológica, a ocupação de camas de enfermaria e de cuidados intensivos e a necessidade de garantir resposta a uma procura que foi exponencial (em janeiro e fevereiro de 2021), e com o intuito de assegurar a mobilização de todos os profissionais de saúde habilitados a uma resposta alinhada com a procura de cuidados observada foram, então, publicadas as guidelines de alocação de recursos.

De acordo com estas diretrizes os estabelecimentos hospitalares do Serviço Nacional de Saúde (SNS) devem assegurar a prontidão da resposta à COVID-19 e o melhor equilíbrio possível das várias respostas 
assistenciais, em especial ao nível da Medicina Intensiva. Para concretização desta priorização os estabelecimentos de saúde:

a) passaram os seus Planos de Contingência para o nivel máximo e procederam à sua revisão e expansão, de forma a maximizar a resposta da capacidade hospitalar à situação epidemiológica local, regional e nacional, em articulação com a Comissão de Acompanhamento da Resposta Nacional em Medicina Intensiva (CARNMI) e as Administraçóes Regionais de Saúde respetivas;

b) suspenderam a atividade assistencial programada não urgente que possa reverter em reforço de cuidados ao doente crítico, desde que tal suspensão, pela sua natureza ou prioridade clinica, não implique risco de vida para os utentes, limitação grave do seu prognóstico e ou limitaçâo de acesso a tratamentos periódicos ou de vigilância, designadamente no âmbito do acompanhamento da gravidez, exacerbaçâo das doenças crónicas ou outros;

c) procederam ao diferimento de atividade cirúrgica programada de prioridade normal ou prioritária;

d) promoveram a alocação de meios humanos para a Medicina Intensiva, de modo a maximizar a capacidade de resposta nesta área, em conformidade com a suspensão e diferimento de atividade assistencial efetuada, mediante proposta da CARNMI e sempre em articulação com a direção clínica de cada unidade.

Considerando o exposto em termos de alocação de recursos o Governo português deu total prioridade ao combate à pandemia relegando para segundo plano todas as outras patologias que careçam de acompanhamento hospitalar. Este facto tem-se traduzido num elevado aumento da mortalidade em Portugal derivado de outras patologias que não as decorrentes de infeção pelo vírus SARS-CoV-2.

No balanço feito pelo Instituto Nacional de Estatística, entre 2 de março e 27 de dezembro de 2020, foram registados, em Portugal, 99.356 óbitos o que representa mais 12.852 quando comparado com a média dos últimos cinco anos. Destes apenas 52\% - ou seja 6.677 foram óbitos por covid-19.

$\mathrm{O}$ acompanhamento às restantes patologias não deixou de existir. O Ministério da Saúde português teve, inclusive, de esclarecer que o Despacho enviado aos hospitais náo manda suspender a cirurgia urgente ou muito prioritária e não se aplica a hospitais como o Institu- 
to Português de Oncologia (dedicado, em exclusivo, ao tratamento de doentes oncológicos). O Ministério da Saúde (MS) assegura que "o diferimento de atividade cirúrgica será sempre feito mediante avaliação clínica e garantia de que não ocorre limitação do prognóstico do utente". Adianta ainda que a cirurgia oncológica prioritária deve ocorrer até 45 dias após a indicação cirúrgica, sublinhando que o despacho vigora até 31 de janeiro. Segundo o MS, "o despacho não se aplica a hospitais como os IPO que, de acordo com o funcionamento em rede, estâo disponíveis para receber os doentes que requeiram cirurgia prioritária durante o período de aplicação do despacho".

Acresce que esta situação pandémica teve especial impacto em alguns direitos consolidados dos doentes, designadamente, nos tempos máximos de resposta garantidos, no livre acesso e circulação no SNS e no direito de visita.

\section{Tempos Máximos de Resposta Garantidos}

A Carta dos Direitos de Acesso aos Cuidados de Saúde, pelos Utentes do Serviço Nacional de Saúde (SNS), determina que o utente do SNS tem direito não só à prestaçáo de cuidados em tempo considerado clinicamente aceitável para a sua condição de saúde, como também o cumprimento dos tempos máximos de resposta garantidos (TMRG) definidos anualmente por portaria do Ministério da Saúde para todo o tipo de prestação de cuidados sem carácter de urgência e ainda a reclamar para a Entidade Reguladora da Saúde caso os TMRG náo sejam cumpridos.

Em Portugal, os tempos máximos de resposta garantidos encontram-se definidos por via legal. Após a Lei n. ${ }^{\circ}$ 15/2014, de 21 de março ter consolidado a legislação em matéria de direitos e deveres do utente dos serviços de saúde, a Portaria n. ${ }^{\circ}$ 153/2017, de 04 de maio, veio definir os Tempos Máximos de Resposta Garantidos no SNS, em função da prioridade clínica. Contudo, de acordo com a informação veiculada pelo Governo, durante a primeira vaga da pandemia, em maio de 2020, houve uma quebra muito significativa na atividade do Serviço Nacional de Saúde devido à pandemia COVID-19, que se traduziu, ao nível dos cuidados de saúde primários, numa queda de consultas de 3.9\% (menos 300.000 consultas), e nas consultas hospitalares de 5.7\% (menos 180.000 consultas). 
No que diz respeito às cirurgias programadas para o SNS, no mesmo período, registou-se uma diminuição de 5.3\% (menos 9.000) e a quebra geral nos serviços de urgência foi de $11.5 \%$.

Sabemos, também, que os exames complementares de diagnóstico tiveram em algumas áreas (como a gastroenterologia) uma descida de $25 \%$. A cirurgia oncológica foi reduzida em 15\% e a procura dos serviços de Urgência desceu, em alguns dos dias registados, 50\%. A SPO - Sociedade Portuguesa de Oncologia - estima uma redução de 80\% nos diagnósticos de cancro (ao Jornal Expresso, 11-05-2020).

A situação degradou-se acentuadamente a partir de janeiro de 2021 .

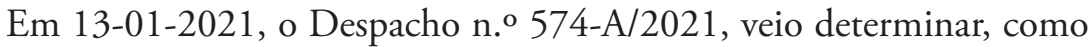
já referimos, que estabelecimentos hospitalares do Serviço Nacional de Saúde (SNS) passem os seus Planos de Contingência para o nível máximo e suspendam a atividade assistencial programada não urgente. Com esta decisão, e de acordo com o objetivo de maximização da capacidade instalada, foi necessário suspender a atividade assistencial programada (que não coloque o utente em risco de vida ou de grave prejuizo, atendendo à sua prioridade clinica).

No final de Dezembro estavam inscritos para uma cirurgia oncológica mais de 5000 doentes. O Ministério da Saúde tem sido interpelado para e anuncia planos para redução das listas de espera, recorrendo ao setor privado e social, mas ainda é cedo para avaliar a realidade prática e o eventual sucesso desses planos. ${ }^{7}$

O que é seguro - de acordo com as atualizações permanentes da Escola Nacional de Saúde Pública - , entre fevereiro de 2020 e fevereiro de 2021, a mortalidade em Portugal, excluídos os números referentes à infeção por SARS-COV2, foi a mais alta dos últimos dez anos.

\section{Livre Acesso e Circulação no SNS}

Em Portugal, o sistema de Livre Acesso e Circulação de Utentes no SNS (LAC), aprovado pelo Despacho n. $5911-\mathrm{B} / 2016$, de 3 de maio, permite ao utente, em conjunto com o médico de família responsável pela referenciação, optar por qualquer uma das unidades hospitalares do SNS onde exista a consulta de especialidade de que necessita.

7 https:/www.publico.pt/2021/02/10/sociedade/noticia/ministerio-saude-prepara-plano-recuperar-cirurgia-oncologica-ficou-1950159 
A referenciação é efetuada de acordo com o interesse do utente, segundo critérios de proximidade geográfica e considerando os tempos médios de resposta nas instituiçóes.

O nível máximo de contingência colocou em causa o livre acesso e circulação de doentes. Atualmente, a oferta de cuidados de saúde recebe atualizaçóes quase diárias, em função da necessidade de abertura de novas enfermarias e hospitais, que procuram amparar uma necessidade desmesurada de cuidados de saúde. Ao mesmo passo, muitos profissionais de saúde com formação específica foram alocados a outras especialidades médicas, designadamente, em plataformas de apoio aos cuidados intensivos e à pneumologia. Esta realidade alterou drasticamente a realidade das redes basilares de referenciação.

\section{Direito de acompanhamento e de visita}

De acordo com a lei portuguesa dos Direitos e deveres do utente dos serviços de saúde (Capítulo III da Lei n. ${ }^{\circ}$ 15/2014, de 21 de março), a todos é reconhecido e garantido o direito de acompanhamento por uma pessoa por si indicada, devendo ser prestada essa informação na admissão pelo serviço. Às mulheres grávidas internadas em estabelecimento de saúde é também reconhecido o direito de acompanhamento, durante todas as fases do trabalho de parto, por qualquer pessoa por si escolhida.

É ainda reconhecido o direito de acompanhamento familiar a crianças internadas em estabelecimento de saúde, bem como a pessoas com deficiência, a pessoas em situação de dependência e a pessoas com doença incurável em estado avançado e em estado final de vida.

Nos casos em que a situação clínica não permita ao utente escolher livremente o acompanhante, os serviços devem promover o direito ao acompanhamento, podendo para esse efeito solicitar a demonstração do parentesco ou da relação com o utente invocados pelo acompanhante.

A Carta dos Direitos do Doente Internado, da Direção Geral de Saúde, no seu ponto 13 refere que o doente internado tem direito à visita dos seus familiares e amigos quando o desejar e os horários o permitam, sempre que não exista contra-indicação. As instituiçóes e os profissionais devem facilitar e mesmo incentivar o apoio afectivo que podem dar "entes significativos" para o doente. As situaçóes familiares mais complicadas onde existem conflitos entre os diferentes familiares e 
/ ou amigos têm que ser ponderadas discreta e subtilmente pelos profissionais. Os doentes que não têm visitas e se sentem isolados devem ter um maior apoio quer do pessoal de saúde, quer do pessoal voluntário devidamente preparado e enquadrado. $\mathrm{O}$ doente internado que se mostre incapaz de compreender ou de se fazer compreender tem direito ao acompanhamento da pessoa que habitualmente lhe presta cuidados e para a qual deve haver condiçôes mínimas.

Quando a pessoa internada náo esteja acompanhada, a administração do estabelecimento de saúde deve diligenciar para que lhe seja prestado o atendimento personalizado necessário e adequado à situação.

Apenas não é permitido acompanhar ou assistir a intervençóes cirúrgicas e a outros exames ou tratamentos que, pela sua natureza, possam ver a sua eficácia e correçáo prejudicadas pela presença do acompanhante, exceto se para tal for dada autorização expressa pelo clínico responsável. Em geral, o acompanhamento não pode comprometer as condiçôes e requisitos técnicos a que deve obedecer a prestação de cuidados médicos.

As unidades de saúde, públicas e privadas, definem os seus regulamentos de visitas em função das dinâmicas dos serviços, sendo certo que, por via de regra, os doentes podem sempre receber visitas, cumprindo as exigências genericamente definidas naqueles regulamentos.

Em certas situaçóes específicas, como as situaçóes de fim de vida, é a própria lei a afirmar perentoriamente um princípio transversal e de valor reforçado ao direito de visita.

Contudo, também os acompanhamentos e as visitas a doentes sofreram importantes revezes com a situação pandémica. Se algumas destas limitaçóes tiveram fundamento direto e objetivo na adequação das condições da prestação de cuidados, e efetuaram-se em estrito respeito pelas recomendaçóes da Direção Geral de Saúde, outras limitaçóes deveram-se a falhas na organização dos serviços e arbitrariedade das opçôes, que tiveram como consequência situaçôes de profunda solidão e isolamento de pessoas especialmente vulneráveis.

Também no que concerne às visitas aos utentes, a pandemia impôs um conjunto de medidas de carácter extraordinário nas Estruturas Residenciais para Idosos (ERPI), Unidades de Cuidados Continuados Integrados (UCCI) da Rede Nacional de Cuidados Continuados Integrados (RNCCI) e Estabelecimentos de Apoio Social para Crianças, Jovens, Pessoas Idosas ou Pessoas com Deficiência. 
Num primeiro momento, as visitas foram absolutamente proibidas na maior parte destes espaços, acreditando-se que a medida seria fundamental para conter as redes de contágio. A partir de maio de 2020, contudo, a Direção Geral de Saúde determinou a cessação da suspensão, definindo limites quer quanto à quantidade e periodicidade das visitas, quer quanto às condiçôes ambientais em que as mesmas devem decorrer, assim proporcionando um retorno parcial aos contactos familiares e sociais fundamentais.

Com a nova e fortíssima vaga pandémica de janeiro de 2021, as limitaçôes ao direito de visita voltaram, embora com menos rigor, ${ }^{8} \mathrm{o}$ que se compreende pelo facto de concomitantemente ter sido feita a campanha de vacinação de todos os utentes e funcionários desses serviços residenciais.

\section{Conclusáo}

Terminamos como começámos, o estado de emergência decorrente da pandemia, em caso algum pode afetar os direitos à vida, à integridade pessoal, à identidade pessoal, à capacidade civil e à cidadania, à náo retroatividade da lei criminal, às garantias de defesa dos arguidos e à liberdade de consciência e de religiáo. Contudo, permite a implementação de certas medidas restritivas. Na saúde, fruto da escassez dos recursos, perante uma oferta inelástica, assistimos ao implementar de guidelines que, necessariamente, acarretam, restriçóes para os doentes quer no acesso aos cuidados de saúde quer no exercício dos seus direitos enquanto doentes. Certo é que essas "restriçôes" não podem colocar em causa a sua vida ou a sua saúde.

8 Por exemplo, as visitas a lares de idosos e as atividades nos centros de dia foram permitidas no período do estado de emergência que começou às 00:00 de dia 15 de janeiro, para tentar conter o avanço da pandemia de covid-19. 


\section{ANÁLISE DOS QUESTIONÁRIOS}

André Dias Pereira e Catarina Zamith de Almeida

Para atingir os objetivos do Projeto, foi decidido que o principal recurso de pesquisa empírica seria um Questionário, disponibilizado através da plataforma online do IJFDUC, dirigido a um número significativo de partes interessadas (instituiçóes de saúde, ONGs de defesa de direitos de pacientes, funcionários públicos, académicos) para recolher os necessários dados. Era importante para a Equipa apresentar um Projeto que não só refletisse a muito relevante análise teórica e concetual dos recursos bibliográficos e técnicos disponíveis, como Legislação e Literatura atualizadas, mas que fosse mais além e permitisse uma pesquisa empírica, incorporando dados recentemente recolhidos e a sua análise, que permitissem propor soluçôes de políticas públicas, viabilizando a construção de sistemas eticamente adequados para dar resposta às dificuldades trazidas pelas situaçôes de pandemia.

O referido Questionário inclui 44 questôes: a maioria delas implica respostas sim / não, embora algumas delas exigissem uma resposta mais detalhada, envolvendo a convocação da opinião do inquirido, combinando, assim, tanto uma perspetiva objetiva das questóes éticas convocadas, como também uma apreciação subjetiva dos problemas identificados.

Foram enviadas dezenas de questionários, nos diversos países e regiốes, a entidades selecionadas, tendo sido recebidos 41 Questionários, dos 5 Ordenamentos Jurídicos convocados, em diferentes áreas de atividade. A população de inquiridos segue o seguinte perfil: 
Quadiro 1 - Número de Inquiridos por Ordenamento Jurídico

\begin{tabular}{|c|c|c|c|c|}
\hline \multicolumn{5}{|c|}{ Número de Inquiridos por Ordenamento Jurídico } \\
\hline Angola & Brasil & Moçambique & Portugal & RAEM \\
\hline 8 & 15 & 5 & 7 & 6 \\
\hline \multicolumn{6}{|c|}{ Sem Submissão de Informação: 0} \\
\hline
\end{tabular}

Quadiro 2 - Número de Inquiridos por Área de Atividade

\begin{tabular}{|c|c|c|c|}
\hline \multicolumn{4}{|c|}{ Número de Inquiridos por Área de Atividade } \\
\hline Direito & Saúde & Administração & Outros \\
\hline 15 & 12 & 3 & 4 \\
\hline \multicolumn{4}{|c|}{ Sem Submissão de Informação: 7} \\
\hline
\end{tabular}

\section{Quadro 3 - Número de Inquiridos por Língua de Resposta}

\begin{tabular}{|c|c|}
\hline Número de Inquiridos por Língua de Resposta \\
\hline Português & Inglês \\
\hline 39 & 2 \\
\hline
\end{tabular}

Ocupando-se este Projeto, entre outros aspetos, da averiguação das questóes da Responsabilidade em Saúde Pública no Mundo Lusófono, o Questionário preparado pela Equipa não poderia deixar de começar por procurar entender a importância da saúde pública na organização do sistema de saúde de cada um dos países envolvidos.

Atentando no exemplo fornecido por Angola, os inquiridos afirmaram que a saúde pública se torna de particular importância sobretudo quando há necessidade de intervenção direta do Estado na saúde, atendendo às circunstâncias deste país, com "infraestruturas de saúde muito exíguas, poucos profissionais e pouca formaçáo". Revela-se a importância deste setor na formação, fazendo chegar às camadas mais fragilizadas da população informaçóes básicas sobre saúde e higiene. Além disso um inquirido menciona que "A falta de saneamento, condiçóes básicas de higiene e o facto de Angola ser uma zona endémica para transmissão de doenças infeciosas, torna a saúde pública fundamental". Neste país, vigora a Lei de Bases do Sistema Nacional de Saúde - Lei n. ${ }^{\circ}$ 21-B/92, de 28 de Agosto, estabelecendo a promoção e garantia da saúde pública como parte da atividade do Estado (artigo 1.\%/2). 
O Decreto Presidencial n. ${ }^{\circ} 11 / 95$, de 29 de dezembro, que fixa as competências do Ministério da Saúde em Moçambique, discorre sobre a responsabilidade deste orgão no âmbito da investigação e vigilância epidemiológica (artigo 3.\%/3), preocupando-se também com o estatuto dos indivíduos que possam comprometer a saúde pública (artigo 3. \%/6/d). Ainda neste país, destaca-se o papel do Instituto Nacional de Saúde, que exerce competências ao nível da prevenção e controlo de doenças epidémicas no contexto da Saúde Pública (conforme estatuído no artigo 4.\%) da Resolução n. ${ }^{\circ} 17 / 2018$, de 1 de junho, que aprova o Estatuto Orgânico do Instituto Nacional de Saúde). Este organismo compreende ainda a direção dos Laboratórios de Saúde Pública (artigo 19. ${ }^{\circ}$ ). Os inquiridos, embora considerando este setor fundamental, apontam a falta de financiamento como razão de não ter um papel mais preponderante na Saúde em Moçambique.

No Brasil, a Lei n. ${ }^{\circ}$ 8.080, de 19 de setembro de 1990, coloca no elenco das competências da direçáo nacional do Sistema Único de Saúde (SUS) definir e coordenar os sistemas da rede de laboratórios de saúde pública (artigo 16.\%/III/b)). O mesmo diploma é sensível às determinantes de saúde (artigo 3. ${ }^{\circ}$ ), estabelecendo como uma das prioridades do SUS a identificação e divulgação dessas determinantes (artigo 5.\%/I). A importância desta área da saúde é demonstrada ainda pela abundância de escolas de saúde pública, entre as quais se destaca a Escola Nacional de Saúde Pública Sérgio Arouca que, para além de se dedicar à investigação, cumpre uma importante função ao nível do ensino da Saúde Pública por meio de mestrados e doutoramentos.

Um inquirido testemunha que: "Caso não fosse o SUS, impossível seria conferir assistência aos 5570 municípios brasileiros. Além disso, em um cenário de escassez de recursos, assim como afetação importante do emprego e renda com as medidas de isolamento social, sem a saúde pública podemos de modo verossímil vislumbrar a barbárie que seria pela prestação de assistência. Não sendo o bastante, ao observar a expansão da rede de saúde, verifica-se que a rede pública não mediu esforços para dar conta da pressão sobre o sistema, ao passo que a rede privada, por si só, não fez um esforço minimamente equivalente.”.

Outro inquirido refere que: "O SUS nasceu do movimento de reforma sanitária, iniciado nos anos 1970, e que por suas diretrizes de universalidade, descentralização e participação da comunidade encontrou eco na Constituiçáo Federal, de 1988, a partir de esforços de 
gestâo e de financiamento de todos os entes federais, caracterizando-se atualmente como a maior política social do país. O Sistema Único de Saúde do Brasil (SUS) atende a toda a população do território brasileiro, sendo que cerca de $25 \%$ (considerada a média nacional) possui plano/seguro privado de saúde para as açóes ambulatoriais e hospitalares - no todo ou em parte. Todavia, enquanto outros sistemas universais do mundo lutam pela consolidação (Canadá, Reino Unido, Portugal), o SUS ainda luta pela sobrevivência, cenário esse ainda mais agravado nos últimos anos considerado o desfinanciamento, além dos quadros de necessidade assistêncial ainda mais oneroso a ser dispendido durante a pandemia da Covid-19.”.

Em Portugal, a Saúde Pública tem relativa importância no currículo da Medicina português, existindo a especialidade de Médico Especialista em Saúde Pública (MSP) ${ }^{1}$, que pode atuar em várias áreas de intervenção do Sistema Nacional de Saúde (SNS), bem como exercer atividades de investigação junto de Universidades, na Indústria Farmacêutica ou Entidades Privadas. Os MSP são representados por uma Associação, a Associação Nacional de Médicos de Saúde Pública, fundada em 1987, a qual oferece oportunidades de formação, nomeadamente um curso de Pós-Graduação na área. A formação pós-graduada na área (mestrados, doutoramentos e outras especializações) é também oferecida pela Escola Nacional de Saúde Pública da Universidade Nova de Lisboa (ENSP-NOVA), pelo que se identificam em Portugal diferentes oportunidades para formaçáo na área, o que atesta a sua relevância. Neste país, os inquiridos entendem que a importância, antes da Pandemia, deste setor, era praticamente nula. Noutra perspetiva, alguns inquiridos esclarecem que a importância nunca foi colocada em causa: simplesmente a importância não era reconhecida ("[...] degradação, em meios e recursos, das unidades de saúde pública”) e a Saúde Pública não era valorizada. Metade dos inquiridos portugueses considera que a Saúde Pública é um pilar fundamental da organização do SNS português.

Um inquirido português revela que: "Sob tutela das Administraçóes Regionais de Saúde e consideradas unidades funcionais dos Agrupamentos de Centros de Saúde, as unidades de Saúde Pública, antes da pandemia da COVID-19, não eram valorizadas em termos de recursos humanos médicos, técnicos de saúde, enfermeiros e administrativos.

1 Nos termos da Portaria n. ${ }^{\circ}$ 141/2014 de 8 de julho. 
A carreira médica de Saúde Pública nunca foi considerada atrativa e as condiçóes do exercício da profissáo sempre foram insuficientes. Em Portugal, há apenas 350 médicos especialistas em Saúde Pública. Há zonas do País onde cada médico tem a seu cargo 12, 13 ou 14 concelhos. É uma situação que já está a ser revista mas de uma forma demasiado lenta.".

No que diz respeito à inclusão da Saúde Pública na Legislação, o Anteprojeto da Lei de Bases da Saúde, elaborado em 2018, por uma Equipa presidida pela Senhora Doutora Maria de Belém Roseira, colocava, quase em jeito premonitório, grande ênfase na problemática da Saúde Pública, dedicando integralmente o Capítulo III da Proposta ${ }^{2}$ (oito Bases, de grande desenvolvimento) a este tópico, versando sobre a centralidade da política de saúde na saúde pública e ainda, designadamente, sobre a necessidade de avaliação dos impactos na saúde pública das diferentes políticas (sociais, de trabalho, ambientais, de obras públicas, entre outras). Dedicou-se especificamente a Base XV às situaçóes de emergência em saúde pública, prevendo-se a possibilidade de requisição de profissionais e estabelecimentos de saúde, assim como a necessidade de atuação da Autoridade de Saúde em sintonia com entidades internacionais, permitindo a "[...] preparação para e na resposta a ameaças, deteção precoce, avaliação e comunicação de risco.” (Base XV/4).

Afastada essa Proposta de lei, identificam-se escassas referências à Saúde Pública no diploma atualmente em vigor, Lei n.o 95/2019 de 4 de setembro (que revogou a anterior Lei de Bases, já de 1990). A Base IV afirma que um dos fundamentos da Política de Saúde é a melhoria do estado de saúde da populaçáo, por meio, designadamente, de uma abordagem de saúde pública. É a Base X que se dedica especificamente a esta matéria, dispondo, sob a epígrafe "Saúde Pública":

1. Compete ao Estado acompanhar a evolução do estado de saúde da população, do bem-estar das pessoas e da comunidade, através do desenvolvimento e da implementação de instrumentos de observação em saúde.

2. O membro do Governo responsável pela área da saúde deve identificar áreas específicas de intervenção, programas e açôes de promoção da saúde e da prevenção da doença ao longo da vida,

2 Pode ser consultada, na sua íntegra, em: Cadernos da Lex Medicinae - n. ${ }^{\circ} 3 \mid$ Lei de Bases da Saúde - Materiais e razóes de um projeto, 2018, pp. 41 e seguintes. 
tendo presentes os problemas de saúde com maior impacto na morbilidade e na mortalidade, os desafios sociodemográficos e a existência de determinantes não modificáveis, bem como sociais, económicos, comerciais, ambientais, de estilo de vida e de acesso aos serviços.

Outras referências surgem no âmbito da genómica e da sua relevância para a Saúde Pública (Base XI, $1 .^{\circ}$ parágrafo), bem como na necessidade de presença da literacia para a saúde nas decisões sobre Saúde Pública (Base XI/2). Maior destaque é dado a esta matéria no elenco das competências da Autoridade de Saúde (Base XXXIV), cujas atribuições tiveram particular interesse no mitigar da Pandemia da SARS-Cov-2. A necessidade de avaliação do impacto de programas, planos ou projetos, públicos ou privados, que possam afetar a saúde pública é estatuída na Base XXXVII.

A RAEM, ao contrário de outras jurisdiçôes, dispunha já de uma base legal para fundamentar as medidas necessárias para controlar a Pandemia: a Lei n. ${ }^{\circ}$ 2/2004, para a prevenção, controlo e tratamento de doenças transmissíveis, publicada na sequência da crise de saúde gerada pela SARS em 2001-2003, que afetou Macau profundamente (cuja lista de doenças foi alterada pela Lei n. $\left.{ }^{\circ} 1 / 2016\right)$. Com base nesta lei, ainda antes da chegada dos primeiros casos a Macau, foi criado o Centro de Coordenação de Contingência do Novo Tipo de Coronavírus, com o objetivo de acompanhar a evolução da pandemia e implementar as medidas consideradas necessárias. Um outro dado que permite explicitar a relevância da saúde pública em Macau é a inclusão, na estrutura orgânico-funcional dos Serviços de Saúde de Macau (Decreto-Lei n. ${ }^{\circ}$ 81/99/M, de 15 de novembro), de um Laboratório de Saúde Pública (artigo 23. ${ }^{\circ}$ ), integrado num subsistema de cuidados de saúde generalizados (artigo 18. ${ }^{\circ}$ ), em cujas atribuiçóes se destaca "Programar e executar as acçóes necessárias ao melhor conhecimento, quer dos factores de risco para a saúde quer da situação epidemiológica, das afecçôes mais relevantes da comunidade e avaliar os respectivos resultados" (23. / / / a)).

Relativamente à Regiáo Administrativa, foi assinalado por um inquirido o facto de ser necessária no território uma política de saúde pública forte, atendendo ao facto de ser um destino turístico com milhóes de visitantes anuais, com centenas de trabalhadores que atravessam a fronteira com a China e Hong Kong todos os dias. Além disso, foi referido que este setor recebeu atenção acrescida depois da Pandemia 
da SARS de 2002. A totalidade dos inquiridos entende que a Saúde Pública é fundamental em Macau.

Partindo deste quadro, denota-se que no universo dos Países/Região Administrativa estudados, a SARS-CoV-2 veio acentuar a importância da saúde pública. Em Angola, novamente o destaque é para a situação económica e política do país: as debilidades económicas da população exigiram que na mitigação da Pandemia se adotassem políticas Estatais que reforçassem a proteção conferida aos cidadãos. Em Portugal, a Saúde Pública passou a surgir como protagonista diária das discussões políticas, condicionando as decisōes tomadas hodiernamente. Especialistas na matéria passaram a ser sistematicamente inquiridos relativamente ao impacto das políticas adotadas no desenvolvimento do número de casos e no avançar das "vagas" de contágio do vírus. Os inquiridos mostraram-se sensíveis a esta acentuação da relevância, tendo-se mencionado um "aumento exponencial da importância atribuída" e referindo-se que "Portugal 'acordou' para a importância destes serviços, que são a primeira linha de defesa contra epidemias e a primeira resposta aos problemas de saúde das populaçóes".

No campo normativo, as opçóes do legislador português foram condicionadas pela emergência da condicionante das preocupaçóes de Saúde Pública, a níveis tão distintos como na Responsabilidade Extracontratual do Estado, cujo regime é estatuído na Lei n. ${ }^{0}$ 67/2007, de 31 de dezembro, a qual consagra uma cláusula geral de indemnização pelo sacrifício, que visa ressarcir danos anormais e especiais, sendo "[...] especiais os danos ou encargos que incidam sobre uma pessoa ou um grupo, sem afetarem a generalidade das pessoas, e anormais os que, ultrapassando os custos próprios da vida em sociedade, mereçam, pela sua gravidade, a tutela do direito" (artigo 2. ${ }^{\circ}$ ). Havendo setores a ser desproporcionadamente afetados pelo Estado de emergência constitucional e sua regulamentação pelo Governo, é claro o "sacrifício" no atual contexto da Pandemia. Em derrogação deste direito de indemnização surge o Decreto-Lei 19-A/2020, de 30 de abril (que estabelece um regime excecional e temporário de reequilíbrio financeiro de contratos de execução duradoura, no âmbito da pandemia da doença COVID-19), cujo artigo $8 .^{\circ}$ afasta esta indemnização durante a pandemia da Covid-19, dispondo que: "Não dão lugar a indemnização pelo sacrifício os danos resultantes de atos regularmente praticados pelo Estado ou outra entidade pública, no exercício das competências conferidas pela 
legislação de saúde pública e de proteção civil, ou no quadro do estado de emergência, para efeitos da prevenção e do combate à pandemia COVID-19, que constitui para o efeito causa de força maior.”. Afigura-se problemática esta norma, questionando-se mesmo a sua constitucionalidade, sobretudo considerando o impacto económico das medidas mitigadoras da SARS-CoV-2. Transpondo o conteúdo da norma para o âmbito da Saúde, é inegável que existe um sacrifício para um cidadão que se vacina com vista à proteção da população em geral e que, pela sua decisão, poderá sofrer danos. Do mesmo modo, é sabido que os doentes não-covid têm sido especialmente prejudicados no direito de acesso ao tratamento, e no direito a tratamento em tempo útil, garantido aliás pela legislaçáo que fixa tempos máximos de espera para consultas e intervenções cirúrgicas ${ }^{3}$.

Dos 37 inquiridos que responderam claramente a esta questão, $38 \%$ revela que a Pandemia colocou em evidência as fragilidades dos sistemas nacionais de saúde; $60 \%$ entende que a Covid trouxe consigo um incremento exponencial da relevância Saúde Pública, permitindo à população compreender a necessidade de adoção de políticas de higiene e saúde universais, valorizando-se a figura do profissional de saúde e a prestação de cuidados de saúde, em geral.

A carreira de saúde pública no campo da Medicina surge, como já tivemos oportunidade de esclarecer, regulada em Portugal. Desde logo, neste país, o Decreto-Lei n. ${ }^{\circ}$ 177/2009, de 4 de agosto, estabelece o regime da carreira especial médica, bem como os respetivos requisitos de habilitação profissional, e estatui, no artigo 7.\%1, que, salvaguardada a possibilidade de integração de outras áreas de exercício profissional, existem à partida "[...] as áreas hospitalar, medicina geral e familiar, saúde pública, medicina legal e medicina do trabalho [...]" (sublinhado nosso). O programa de formação da área de especialização de Saúde Pública é regulado pela Portaria n. ${ }^{\circ} 141 / 2014$, de 8 de julho. Este plano inclui estágios em campos tão diversificados como saúde comunitária, investigação epidemiológica em saúde pública, ou auditoria em saúde pública. Entre as competências a adquirir, pretende-se que os internos dominem, entre outras áreas, as questôes de epidemiologia e controlo das doenças transmissíveis bem como tomem conhecimento dos fatores demográficos, sociais, biológicos e ambientais que influenciam a

3 Portaria n. ${ }^{o}$ 153/2017, de 4 de maio. 
saúde. Um inquirido esclarece que "no passado havia, de facto, 3 carreiras médicas: clínica geral, hospitalar e saúde pública”, Atualmente, não obstante, "Sendo integrada na carreira médica e sendo uma especialidade médica, a Saúde Pública, é como todas as restantes especialidades, regulada pela Ordem dos Médicos, dispondo de um colégio de especialidade próprio. Integra, a nível internacional, o board de Medicina de Saúde Pública ("Public Health Medicine") da Uniáo Europeia dos Médicos Especialistas (UEMS).”.

Do mesmo modo, na RAEM, a carreira médica de saúde pública surge prevista na Lei n. ${ }^{\circ}$ 10/2010 (artigo 8. $\left.{ }^{\circ} / 1 / 3\right)$ ). Um inquirido esclarece que a carreira médica em Macau inclui a medicina hospitalar, medicina geral, medicina de saúde pública, medicina dentária e medicina tradicional chinesa. Assim, há um ramo de saúde pública no internato complementar que habilita o médico para o exercício da especialidade de saúde pública (Decreto-Lei n. ${ }^{\circ}$ 8/99/M de 15 de Março).

No Brasil, para além da carreira do sanitarista (Portaria n. ${ }^{\circ} 256$, de 11 de março de 2013, artigo $5 .^{\circ}$ que o define como sendo um " [...] profissional de nível superior, graduado na área da saúde com pós-graduação em saúde pública ou coletiva, ou graduado em uma dessas áreas."), existe, complementarmente ${ }^{4}$, o profissional de saúde coletiva, cuja função implica uma visão mais alargada da saúde pública, que vai além das questóes epidemiológicas e que tem em atenção as outras áreas de conhecimento que afetam a saúde, nomeadamente as variantes sociais da saúde (habitação, educação, etc.). Estes profissionais não são graduados em Medicina, têm uma outra formação académica que lhes confere o grau de bacharelato em Saúde Coletiva. Trabalham na "área-meio" das instituições de saúde, assumindo funçóes de cariz administrativo, alertando, agora com a Pandemia, para as variantes que estão a afetar a resposta destas instituiçôes à Covid, recomendando uma atuação articulada das diferentes áreas. Trata-se de uma experiência que apresenta resultados muito positivos no Brasil e que, a nosso ver, poderia ser replicada noutros países. Assim, uma das recomendaçóes para os países envolvidos/RAEM, é a criação de uma figura equiparável ao técnico de saúde coletiva, desempenhada por profissionais com

${ }^{4}$ Fernando CUPERTINO. Transcrições do Workshop realizado no âmbito do Projeto, subordinado ao Tema: A Pandemia Covid-19 no Espaço da Lusofonia, retificadas e aprovadas pelo Orador. 
formação especializada (por exemplo, com formação de base de enfermagem ou por meio de um curso disponibilizado no ensino politécnico) que se ocupem de apoiar os médicos de saúde pública em situaçôes agudas de crise pandémica, nomeadamente exercendo funçôes de rastreio e planificando açóes como a administração de vacinas (determinaçáo de prioridades, por exemplo). Desenvolver uma ocupação específica nesta área pretende aliviar o desvio de profissionais de saúde especializados para funçóes de rastreio realizadas, por exemplo, como em Portugal, por via telefónica (SNS 24).

Em Angola e Moçambique, os inquiridos não parecem muito certos quanto à existência, ou não, dessa regulaçáo. No primeiro país, apenas 3 inquiridos respondem em sentido afirmativo. No segundo, o único inquirido que respondeu à questão, entende que esta carreira está regulada.

Dentro do Direito da Saúde, nem sempre a matéria da Saúde Pública é estudada. Em Angola, não há cursos de Direito que incluam o estudo da disciplina de Direito da Saúde, havendo, apenas, cursos pós graduados que culminam na produção de teses e dissertaçóes na área do Direito da Saúde. Se se olhar ao caso português, é preciso ter em conta que, à partida, o Direito da Saúde em si não é uma área do Direito que recebe grande atenção no universo jurídico, verificando-se, não obstante, recentemente, um crescente interesse, não só pela sua investigação, mas também prática jurídica, com escritórios de advogados a surgir com o Direito da Saúde como área exclusiva de atuação ou a incorporar esse âmbito no leque de áreas jurídicas mais clássicas. Atendendo à matéria de Saúde Pública em específico, poucas oportunidades de formação para os juristas vão surgindo. De destacar, nos últimos anos, dois cursos de Pós-graduação preparados pelo Centro de Direito Biomédico da Faculdade de Direito da Universidade de Coimbra (CDB): a primeira edição, em 2016, e a segunda, mais recentemente, em 2019, reunindo especialistas da área da Saúde e do Direito. Publicaçóes sobre a temática a mencionar são, desde logo, a Portuguese Journal of Public Health, anteriormente sob o título de Revista Portuguesa de Direito da Saúde, cuja responsabilidade de edição é da ENSP-NOVA.

No Brasil, os inquiridos relatam que se trata de uma disciplina oferecida por algumas instituiçóes que lecionam direito. Não obstante, surge mais frequentemente em cursos de especialização ou pós-graduação ou como disciplina não obrigatória na formação pós-graduada, pelo 
que os 12 inquiridos que responderam à questão, respondem em sentido afirmativo.

Dediquemos as próximas páginas à análise dos Sistemas de Saúde dos territórios envolvidos no Estudo. Quanto à caraterização, per se, destes Sistemas, opondo aqueles que assumem um caráter Bismarckiano (seguros obrigatórios) aos estruturados num formato Beveridgiano (financiado por impostos), poderemos dizer que o Sistema português é, indubitavelmente, um sistema misto ${ }^{5}$, combinando o SNS, financiado pelo Estado, com seguros privados contratualizados pelos cidadãos ${ }^{6}$. No Relatório de Evolução da Atividade Seguradora do 3.o Trimestre de 2020, publicado pela Autoridade de Supervisão de Seguros e Fundos de Pensóes (ASF), houve um crescimento de $8,9 \%$ na produção de seguro de Doença face a 2019, no ramo dos seguros não vida 7 . Estima-se que mais de 3,15 milhóes de portugueses usufruam de seguros de saúde. Já o SNS tem raiz na Constituição da República Portuguesa, especificamente no seu artigo $64 .^{\circ}$, o qual estabelece o direito à proteção da saúde, cujo número dois, alínea a), dispóe que este direito é designadamente realizado "Através de um serviço nacional de saúde universal e geral e, tendo em conta as condiçôes económicas e sociais dos cidadãos, tendencialmente gratuito;". O inciso "tendencialmente" colocado neste artigo autoriza a cobrança de taxas moderadoras ${ }^{8}$, atendendo aos limites e diretrizes que constam da Lei de Bases da Saúde,

5 Quanto à interação Estado-SNS-Privados, cfr: O Setor Da Saúde: Organização, Concorrência E Regulação, coord. António Mendes e Francisco André, Caleidoscópio e Confederação Empresarial de Portugal, 2017.

6 Sobre a articulação do Sistema Público e Privado é muito relevante e esclarecedor o Acórdão do Tribunal Constitucional n. ${ }^{\circ}$ 731/95, de 14 de dezembro [Relator: Conselheiro Alves Correia], que dispóe o seguinte: “[...] o texto constitucional não perfilhou um modelo de monopólio do sector público de prestação de cuidados de saúde — tendencialmente coincidente com o Serviço Nacional de Saúde —, antes admite a existência de um sector privado de prestação de cuidados de saúde em relação de complementaridade e até de concorrência com o sector público." (parágrafo 5.2).

7 Relatório disponível em: https://www.asf.com.pt/NR/rdonlyres/8BD33AE3-9A2D-4D8F-92D0-1EF3039A877E/0/REAS_3T2020_3.pdf (último acesso a $10 / 02 / 2021)$

8 Tem-se assistido ao abandono progressivo das Taxas Moderadoras, desde $1 \mathrm{de}$ janeiro de 2021, para além das isençóes já conhecidas, estas estáo dispensadas nas consultas de cuidados de saúde primários e também nos exames complementares de diagnóstico e terapêutica prescritos no âmbito da rede de prestação de cuidados de saúde primários e realizados no mesmo âmbito. 
Base 24. Do total dos gastos com a saúde, a OCDE estima que $66 \%$ da despesa seja suportada pelo Estado ${ }^{9}$, por via do financiamento direto do Governo ("government schemes") e seguros da segurança social. A mesma entidade denotou em Portugal, entre 2009 e 2017, um aumento de $3 \%$ dos quantitativos de gastos com saúde suportados pelos cidadãos "out-of-pocket". Na aquisição de medicamentos, a OCDE reporta que $55 \%$ dos gastos são suportados pelo Estado, $1 \%$ por seguradoras e $44 \%$ pelos cidadáos ${ }^{10}$. Assim, a presença dos seguros de saúde no sistema português tem sido crescente e tem aumentado a par e passo da evolução da Pandemia. O interesse nos seguros consolidou-se depois de se ter esclarecido que grande parte das seguradoras iam comparticipar nos custos do teste da Covid-19 (Multicare, Advancecare, Allianz, Médis, Montepio, Future Healthcare, Generali...), embora prevendo-se a necessidade de prescrição médica para estes testes. Outros custos, nomeadamente Kits de Proteção Médica (EPI), são comparticipados por algumas seguradoras, embora custos de internamento relacionados com a SARS-Cov-2, regra geral, não estão abrangidos pelas apólices, uma vez que as epidemias estão usualmente excluídas dos seguros de saúde. Dos 7 inquiridos portugueses, 3 consideram o sistema "misto" e 4 "beveridgiano".

O sistema angolano segue o mesmo modelo misto, surgindo, não obstante, o segmento Beveridgiano como maioritário. São poucas instituiçôes públicas que usam o sistema Bismarckiano, por oposição, no setor privado são as grandes empresas que usam o sistema Bismarckiano. Segundo Cristóvão Simôes ${ }^{11}$, Reitor da Universidade José Eduardo dos Santos, orador convidado no Workshop realizado no âmbito do presente Estudo, o sistema de saúde angolano é um Sistema de saúde frágil e insuficiente, caraterizado pelo número reduzido de unidades sanitárias, com escassos e pouco especializados profissionais.

9 Dados de 2017, disponíveis em: https://www.oecd-ilibrary.org/sites/7f66369c-en/index.html?itemId=/content/component/7f66369c-en (último acesso a 10/02/2021)

10 Dados de 2017, disponíveis em: https:/www.oecd-ilibrary.org/sites/3b2d8ac1-en/index.html?itemId=/content/component/3b2d8ac1-en (último acesso a 10/02/2021)

11 Cristóvão Simốes, Transcriçôes do Workshop realizado no âmbito do Projeto, subordinado ao Tema: A Pandemia Covid-19 no Espaço da Lusofonia, retificadas e aprovadas pelo Orador. 
Existe em Portugal um Sistema Público de Saúde, financiado pelo Estado. O Estatuto do SNS foi aprovado pelo Decreto-Lei n. ${ }^{\circ} 11 / 93$, de 15 de janeiro (atualmente em vigor na redaçáo dada pela Lei n. ${ }^{\circ} 82-B / 2014$, de 31 de dezembro), o qual se prevê que, não obstante a sua natureza Estadual, seja dividido em cinco regiōes de saúde, subdivididas em sub-regióes, por sua vez divididas em áreas de saúde (artigos $3 .^{\circ}, 4 .^{\circ}$ e $5 .^{\circ}$ do diploma). O financiamento do SNS está regulado pelos artigos $23 .^{\circ}$ e seguintes do Decreto: o Estado surge como responsável pelos encargos, a par, designadamente, dos utentes não beneficiários do SNS. O artigo $24 .^{\circ}$ explicitamente consagra a possibilidade de contratualização de seguros de saúde. Recentemente, o papel dos Municípios na gestão do SNS recebeu as alteraçóes que constam do Decreto Lei no 23/2019, de 30 de janeiro de 2019, que transferem para o Município, desde logo, competências para manutenção, conservação e equipamento das instalaçôes de unidades de prestação de cuidados de saúde primários. No entanto, apenas uma percentagem baixa de $\mathrm{Mu}-$ nicípios concordou assumir imediatamente estas responsabilidades no domínio da saúde, beneficiando do regime que permite efetivar esta transferência até 2021 (artigo 20.\%/2).

Também financiado pelo Estado, mas contando com apoio financeiro por meio de doaçóes de organizaçôes internacionais, como a OMS e a UE, surge o Sistema Nacional de Saúde (SNS) de Angola. A Lei de Bases do Sistema Nacional de Saúde contempla a possibilidade de o Estado contratar com entidades privadas para a prestação de cuidados de saúde à populaçáo (artigo 11.\%/3). O SNS presta cuidados de saúde de forma universal e tendencialmente gratuita (artigo 22. ${ }^{\circ}$, já que podem ser cobradas taxas moderadoras, nos termos do artigo $28 .^{\circ}$ ), financiando-se pelo Orçamento Geral do Estado (artigo 27. ${ }^{\circ}$ ), mas cobrando receitas próprias e podendo receber doaçóes.

O seu nível é bipartido, incluindo uma componente Central (Estadual) e Local (Provincial e Municipal) - artigo 17. ${ }^{\circ}$. Identificam-se, no SNS angolano ${ }^{12}$, três níveis de hierarquia (artigo $12^{\circ}$ ): o nível de base é representado pelos Cuidados Primários de Saúde, dispensados pelos postos e centros de saúde, postos de enfermagem e consultórios médicos e hospitais Municipais. Num plano intermédio (secundário)

12 Cristóvão SIMÓES. Transcriçôes da Conferência Final realizada no âmbito do Projeto, retificadas e aprovadas pelo Orador. 
surgem os hospitais gerais. O cume da pirâmide cabe aos hospitais de referência, mono ou polivalentes, diferenciados e especializados.

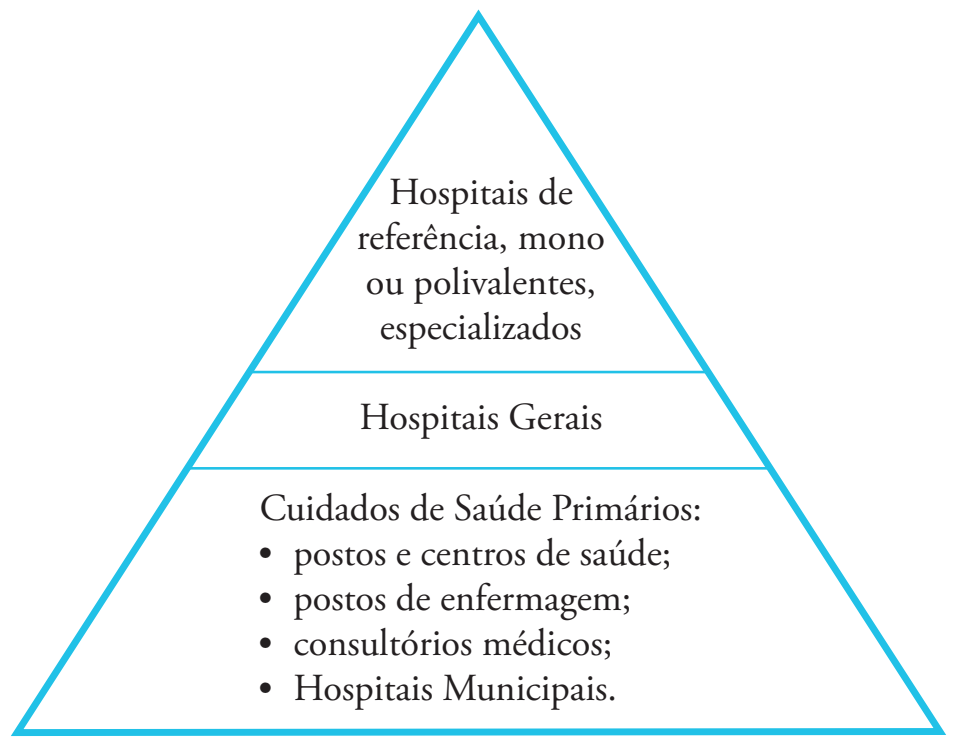

Figura 1 - Hierarquia do SNS em Angola

No Brasil, o diploma estruturante nesta matéria é a Lei n. ${ }^{\circ} 8.080$, de 19 de setembro de 1990, que estabelece o Sistema Único de Saúde (SUS), a qual estabelece que "A iniciativa privada poderá participar do Sistema Único de Saúde (SUS), em caráter complementar" (artigo 4. $\% / \$ 2$ ) e dispondo de um Título (Título II) prevendo a possibilidade de a assistência à saúde ser feita por meio de iniciativa privada e possibilidade de articulaçáa entre o SUS e privados, designadamente por incapacidade de resposta do SUS. O SUS é financiado pelo orçamento da seguridade social (artigo 31. ${ }^{\circ}$ ), dispondo ainda de receitas, por exemplo, de doaçóes e de taxas e emolumentos cobrados pelos seus serviços. Um inquirido explicou que, não obstante a cobertura universal do SUS, "cerca de $25 \%$ da populaçáo possui plano/seguro privado de saúde para as açóes ambulatoriais e hospitalares", valor com alguma expressão, pelo que considera que o sistema é misto.

Em Moçambique, o sistema público de saúde foi instituído pela Lei n. ${ }^{\circ}$ 25/91 de 31 de dezembro, sendo que a articulação com entidades privadas é prevista pela Lei $n .^{\circ} 26 / 91$ de 31 de dezembro (alterada pela Lei n. ${ }^{\circ} 24 / 2009$ de 28 de setembro). Os inquiridos revelam a 
destruturação do sistema público de saúde, não se revendo no incremento da expressividade de seguros privados.

Na RAEM funcionam os Serviços de Saúde de Macau (SSM), dotados de autonomia administrativa, financeira e patrimonial (artigo $1^{\circ} \mathrm{do}$ Decreto-Lei n. ${ }^{\circ}$ 81/99/M, de 15 de novembro). Nos termos do artigo $52 .^{\circ}$ do Decreto, constituem recursos dos SSM dotaçóes inscritas no Orçamento Geral da RAEM, contribuições descontadas aos trabalhadores da Administração Pública para a assistência médica e medicamentosa mas, também, entre outros recursos, as importâncias cobradas pelos serviços prestados. Foi esclarecido por um inquirido que, em Macau, o sistema é de origem Beveridgiano, apresentando cada vez mais um caráter misto, por força da contratação de seguros privados de saúde a nível empresarial, quando, após 1999 , se verificou um decréscimo da qualidade desses serviços, daí que outro inquirido tenha até classificado o sistema de misto. Foi-nos esclarecido também que de acordo com o artigo 123. ${ }^{\circ}$ da Lei Básica, o Governo da Regiáo Administrativa Especial de Macau define, por si próprio, a política respeitante à promoção dos serviços de medicina e saúde.

O papel do terceiro setor (setor social, cooperativo, misericórdias, fundaçóes caritativas) no âmbito da prestação de cuidados de saúde entende-se que devia ser potenciado, em Portugal. O terceiro setor assume um papel importante ${ }^{13}$, por exemplo, ao nível das unidades de cuidados continuados integrados. A presença de "[...] instituiçôes particulares de solidariedade social e de outras de reconhecido interesse público sem carácter lucrativo [...]" está prevista no artigo 63.\%/5 da CRP, recebendo o apoio e fiscalização do Estado, "[...] com vista à prossecução de objetivos de solidariedade social [...]". O mesmo problema enfrenta Angola, país no qual o terceiro setor é quase inexistente, resumindo-se a instituiçõos religiosas (Igreja Católica e Igreja Evangélica Congregacional) que têm hospitais nas suas Missôes que vão prestando algum serviço na prestação de cuidados de saúde. Cristóvão Simôes ${ }^{14}$ assinalou ainda

13 Sobre o assunto, vide: Pedro M. LOPES DE OLIVEIRA. A importância do terceiro setor na prestação de cuidados de saúde: Exemplo da Região Centro de Portugal, Dissertação para obtenção do Grau de Mestre em Gestấo de Unidades de Saúde, Universidade da Beira Interior, Ciências Sociais e Humanas, fevereiro 2013.

14 Cristóvão SIMÕES. Transcrições do Workshop realizado no âmbito do Projeto, subordinado ao Tema: A Pandemia Covid-19 no Espaço da Lusofonia, retificadas e aprovadas pelo Orador. 
um programa de apoio social muito importante chamado "Kwenda", que significa em muitas das línguas nacionais de Angola "viajar”, "andar", "ir", "vir"... Este programa tem agentes de desenvolvimento comunitário e sanitários (ADECOS) cuja missão é registar áreas e pessoas com níveis graves de pobreza e catalogar áreas de risco de contaminação da covid-19. Também se dedicam à educaçáo das pessoas para o uso de medidas pessoais e comunitárias de prevenção da covid-19. No Brasil, a capacidade de resposta do terceiro setor foi potenciada por meio da Lei no 13.995 , de 5 de maio de 2020, a qual prevê a prestação de auxílio financeiro pela Uniāo às santas casas e hospitais filantrópicos, que, sem fins lucrativos, participam no combate à SARS-CoV-2.

$\mathrm{Na}$ RAEM, um inquirido destaca o papel do terceiro setor sobretudo junto dos cidadãos mais carenciados e trabalhadores migrantes.

Dos 30 inquiridos que responderam claramente a esta questão, $65 \%$ entende que o terceiro setor funciona de modo complementar aos sistemas nacionais de saúde. No Brasil, os inquiridos sublinham que este setor permite aliviar a sobrecarga dos sistemas públicos. Na RAEM e Angola, há quem refira que o setor é quase inexistente, muito limitado, mas que, apesar da sua fraca valorização, desempenha um papel preponderante junto dos grupos populacionais mais fragilizados. Esta é uma tendência de resposta comum a outros ordenamentos: $30 \%$ do total de inquiridos reconhece a importância junto de grupos populacionais específicos. Um inquirido de Angola refere, a este respeito, que “ [ ] existem clínicas privadas com limitação de acesso pela maioria da população devido aos altos custos. Por outro lado, existem instituiçóes de carácter caritativo e misericórdias sobretudo vinculadas a instituiçóes religiosas que prestam serviço sem pagamento ou com pagamento pecuniário cujos custos são muito mais baixos se comparados com os serviços prestados por clínicas privadas.".

Avaliando em seguida o grau de preparação para situaçóes de emergência, denota-se que, na grande parte das instituiçóes inquiridas, anteriormente à pandemia da SARS-CoV-2, não existiam mecanismos de preparação e resposta para situaçôes de emergência (por exemplo: teletrabalho, uso de equipamento de proteçấo individual, telemedicina, ensino à distância, limitação de visitas, etc.). Em Angola, apenas dois dos inquiridos respondeu afirmativamente a esta questão: não havia, no geral, implementação destes mecanismos nas instituiçóes. Foi reportado apenas um caso de preparaçáo, tanto em Moçambique como 
na RAEM. A mesma situação de falta de preparação se identificava em Portugal: se olharmos ao caso da Universidade de Coimbra, a instituição a que um número relevante de investigadores da Equipa está afiliado, estes mecanismos não existiam. No Brasil, foram reportados onze casos de instituiçôes que previam já a possibilidade de adoção de trabalho remoto em caso de necessidade, nomeadamente um dos casos para prestação de apoio à família e que será extendido, em breve, para proteção da maternidade (grávidas e mães de crianças até aos dois anos) e para aqueles que têm a seu cargo portadores de deficiência. Em Moçambique, um dos inquiridos referiu que a instituição onde trabalha havia já há muito investido na implementação e melhoria da telemedicina, vendo com bons olhos a imposiçáo de obrigatoriedade destes mecanismos, por agilizarem e flexibilizarem a prestação de cuidados de saúde.

Considerando agora a opiniâo dos inquiridos, quanto à obrigatoriedade destes mecanismos nas instituiçôes ligadas à saúde, quase todos se mostraram favoráveis à sua imposição. Da parte da Equipa, ficou claro que seria benéfico pelo menos a manutenção de stocks de EPI, nomeadamente máscaras cirúrgicas e álcool-gel e equipamentos de medição da temperatura, pelo menos nas instituiçóes ligadas à prestação de cuidados de saúde. Foi reconhecida ainda grande utilidade à organização de simulacros, semelhantes aos que são obrigatórios para terramotos e incêndios, por exemplo, organizando uma situação em que em duas semanas, numa Escola, se adota o ensino à distância, cumprindo protocolos para o efeito preparados. Apenas um inqurido se manifestou contra esta obrigatoriedade, por entender que uma imposição legal náo atenderá ao contexto particular de cada instituição de saúde.

Relativamente a Portugal, um inquirido esclarece que "se faz planeamento de contingência em saúde pública (de âmbito nacional e implementação local) desde 2004 e que em 2007 foi elaborado o plano de contingência nacional para a pandemia de gripe (i.e., dois anos antes da emergência da chamada "gripe A")".

Quanto à existência de uma Instituição Nacional que emite recomendaçôes para atuar em caso de pandemia, em Angola essa função cabe à Direção Nacional de Saúde, um órgáo dentro da estrutura orgânica do Ministério da Saúde. Existe também uma Comissão Interministerial de Combate à Covid-19. 
No Brasil, foi-nos dito que: "[...] historicamente, a coordenação nacional para as pandemias (ao exemplo da AIDS, H1N1) esteve sob a guarida da Secretaria Nacional de Vigilância em Saúde, subordinada ao Ministério da Saúde (União), a partir de comandos debatidos e pactuados em Comissóes Intergestores, sem deixar de considerar as competências específicas da Agência Nacional de Vigilância Sanitária (Anvisa). No ano 2020, durante a pandemia da Covid-19, em face das dificuldades com um discurso uníssono em prol das medidas de prevenção, controle e mitigação da pandemia, provocado, o Supremo Tribunal Federal (Corte Constitucional do Brasil) posicionou-se por reconhecer a competência concorrente dos entes estadual, distrital e municipal para os fins da emissão de recomendaçóes em seus respectivos territórios, sendo assim, a autoridade emitente das recomendaçóes é pertencente ao setor público, em qualquer das esferas.".

Em Portugal essa instituição é a Direção-Geral da Saúde (DGS), que depende do Governo. O Decreto Regulamentar n. ${ }^{\circ}$ 14/2012, de 26 de janeiro aprova a orgânica da DGS enquanto serviço central do Ministério da Saúde (que dispóe não só de receitas provenientes do Orçamento de Estado como também de receitas próprias - artigo 6. ${ }^{\circ}$ ), integrado na administração direta do Estado, dotado de autonomia administrativa (artigo $1 .^{\circ}$ ). Entre as atribuiçốes da DGS está a vigilância epidemiológica de determinantes da saúde e de doenças transmissíveis, assim como a coordenação de sistemas de alerta e resposta apropriada a emergências de saúde pública (artigo 2.\%/2/b)). A emissão de normas e orientaçôes e a colaboração na definição de políticas e prioridades do Ministério Público integram também a missão da DGS (2.o/2/a) e e)). Em 2017, a linha Saúde 24, que assumiu um relevante papel durante a Pandemia, (Centro de Contacto do Serviço Nacional de Saúde - CCSNS), sujeita a uma nova configuração, saiu da competência da DGS para os SPMS - Serviços Partilhados do Ministério da Saúde, E. P. E., (SPMS, E. P. E.), por meio do Decreto-Lei n. ${ }^{\circ}$ 69/2017, de 16 de junho. Um inquirido esclarece a competência do INFARMED também para emitir recomendaçóes.

Em Macau, por meio do Despacho do Chefe do Executivo n. ${ }^{\circ}$ 23/2020, de 21 de janeiro, foi criado o Centro de Coordenaçáo de Contingência do Novo Tipo de Coronavírus (cujo apoio financeiro, administrativo e logístico cabe aos Serviços de Saúde - artigo 60 - e sob a dependência direta do Chefe do Executivo - artigo 3. ${ }^{\circ}$ ) responsável 
pela planificação global, orientação e coordenação das açóes das entidades públicas e privadas, no âmbito da prevenção, controlo e tratamento das infeçóes pelo novo tipo de coronavírus. Um inquirido salienta ainda o papel da Secretaria para a Saúde e os Assuntos Sociais e Cultura e da Direcção de Serviços de Saúde (SSM), bem como do Centro de Prevenção e Controlo da Doença dos Serviços de Saúde.

Em Moçambique, foi salientado o papel do Decreto Presidencial n. ${ }^{\circ} 41 / 2020$ de 28 de dezembro, através do qual "foram definidas as competências, organização e funcionamento da Entidade Coordenadora de Gestão e Redução do Risco de Desastres, criada por via da Lei n. ${ }^{\circ} 10 / 2020$, de 24 de Agosto, com a designação de Instituto Nacional de Gestáo e Redução do Risco de Desastres. Entre os respectivos órgãos temos o Conselho Técnico de Gestão e Redução do Risco de Desastres, órgão multissectorial de aconselhamento técnico ao Conselho Coordenador de Gestão e Redução do Risco de Desastres sobre matérias de gestão e redução do risco de desastres, presidido pelo Presidente do Instituto e integra os directores e representantes de diversas áreas, incluindo da saúde. Na prossecução dos seus objectivos, compete ao Conselho Técnico de Gestão e Redução do Risco de Desastres, entre outras funçóes: coordenar os sistemas sectoriais de alerta e aviso prévio sobre fenómenos de origem meteorológica, hidrológica, geológica, epidemias, pandemias e impactos na segurança alimentar e nutricional; bem como propor ao Conselho Coordenador de Gestão e Redução do Risco de Desastres a declaração da Situação de Calamidade Pública ou de Emergência.".

Avaliando a resposta à emergência de saúde pública SARS-CoV-2, especificamente no que atem à alocação de recursos públicos no que respeita à prevenção, tratamento e reabilitaçáo dos doentes COVID, os dados presentemente disponíveis relativos a Portugal são os analisados pelo Jornal Público ${ }^{15}$, que apontam como maior gasto do Estado a compra de EPI, ascendendo a 212.743.342 euros. Para além deste equipamento, que visa prevenir a propagação do vírus, a testagem também assumiu uma parte substancial das despesas do Estado, quase 60 milhôes de euros. Um dos contratos com valor mais expressivo foi a aquisição de 243 ventiladores a uma empresa de Cantão, no montante

15 Mapa Interativo disponível em: https://www.publico.pt/interactivo/gastos-covid-19\#/ (último acesso a 13/02/2021). 
de mais de 10 milhóes de euros (de um total de quase 40 milhóes gastos na compra de ventiladores, valor que náo compreende os 4 milhôes despendidos com os acessórios necessários a estes equipamentos). Outros gastos com tratamento incluíram a compra de medicamentos (cerca de 11 milhóes). Não obstante os elevados custos de prevenção contra a SARS-CoV-2, é compreensível que se aposte cada vez mais neste vetor de mitigaçáo da Pandemia. É representativo o elevado custo de manutenção de doentes nos cuidados intensivos, quando os doentes são encaminhados para instituiçóes privadas: o internamento de um doente Covid com tratamento com recurso a ventilador pode custar ao Estado 8431 euros $^{16}$, que os privados entendem ser bastante inferior ao real custo do serviço.

Os inquiridos portugueses estão, no geral, insatisfeitos com a alocação de recursos. Dos 7, 4 avaliam-na como negativa e 3 como razoável (por ter sido feita na medida do possível/disponível). Entende-se que a alocação foi mal feita, com falhas na distribuição, recursos mal geridos, fraco investimento na prevençáo. Especial destaque foi dado por um inquirido quanto às falhas no apoio ao setor social, que dependeu de apoio de privados no fornecimento de EPI e outros equipamentos essenciais.

Em Angola, as opiniōes relativas a esta matéria foram relativamente divididas: por um lado, alguns inquiridos consideraram que essa alocação tem sido feita na medida das disponibilidades do Orçamento do Estado e, neste sentido, tem sido positiva. Por outro lado, consideram que a resposta foi demasiado centralizada, não chegando a todo o território e que a prevenção não recebeu recursos suficientes.

No Brasil, dos 8 inquiridos que responderam à questáo, 6 avaliam negativamente a alocação feita (alocação razoável e positiva receberam, respetivamente, um voto). Defendeu-se a necessidade de serem mobilizados mais recursos e se fazer uma melhor gestão destes. Condenou-se o desvio de verbas públicas, a demora na distribuição de materiais e o investimento em tratamentos comprovadamente ineficazes do ponto de vista científico.

16 Vide, como referência, o Apêndice I do Clausulado tipo para adesão ao Acordo entre as ARS e as entidades privadas para a prestaçáo de cuidados de saúde no âmbito das medidas excecionais e temporárias para tratamento da COVID-19, disponível em: http://www.acss.min-saude.pt/wp-content/uploads/2020/11/Clausulado-Tipo-Convencao-Hospitais-Privados_V_Nov-2020.pdf (último acesso a 13/02/2021). 
Em Moçambique, a alocação de recursos foi classificada, por um inquirido de "péssima". Outro considera que foi feito o que era possível, defendendo que a alocação foi, assim, razoável.

Na RAEM, em lugar de uma estratégia de mitigação, denota-se a adoção de procedimentos com vista a evitar a entrada do vírus no território, bem como de impedir a sua transmissão comunitária. A alocação de recursos incide, assim, na prevenção da propagação (distribuição organizada de máscaras aos residentes, instalação de equipamentos de medição da temperatura em locais públicos, etc.). Dos 5 inquiridos que responderam à questão, todos estavam satisfeitos com a alocação implementada no território.

Um inquirido testemunhou que "A RAEM adoptou uma estratégia de supressão/eliminação epidémica. A prevenção, tratamento e reabilitação dos doentes COVID-19 tem sido objectivo com elevado grau de prioridade na alocação de recursos públicos (especialmente a prevençáo)".

Atendendo a estes valores e dados, entende a Equipa que a prevenção deve assumir a principal prioridade na alocação dos recursos públicos na saúde na gestấo desta pandemia. Os custos com EPI, informação e campanhas de esclarecimento, embora significativos, permitem controlar o desenvolvimento das fases da Pandemia, evitar infeçóes e mortes. Entre as respostas dos inquiridos, a prevençáo pareceu surgir também como essencial: aumento da capacidade de testagem, disponibilização de informação aos cidadáos, aumento do número de leitos hospitalares e, no geral, investimento no setor da saúde (instalaçóes hospitalares, equipamentos, etc.).

Perante os dados recolhidos, ficou claro para a Equipa que a transmissão de informação relativa à resposta de emergência de saúde pública COVID-19, por parte das autoridades oficiais, tem sido pouco rápida e clara, em Portugal. As autoridades demoraram a aconselhar a utilização de máscaras à população, negaram que o transporte aéreo fosse uma fonte rápida de propagação do vírus, não obstante, em sentido aparentemente contrário, terem referido a necessidade de se arejarem as casas, e nada fizeram, na primeira onda do vírus, relativamente aos transportes públicos, mormente urbanos - um dos locais de maior concentração de pessoas e propício a contágios, sem medidas práticas de distanciamento obrigatório, a não ser, a dada altura, e em contramão, a redução da sua frequência... Mais recentemente, depois de muitos 
países europeus terem abandonado o uso das chamadas "máscaras sociais", por náo oferecerem as necessárias garantias de segurança contra as novas estirpes de SARS-CoV-2 e os Estados Unidos da América recomendarem a utilização de duas máscaras sobrepostas em vez de uma só, as autoridades têm tido dificuldades em rápida e eficazmente esclarecer a população quanto às novidades de prevenção. Disseminada a ideia de que a correta utilização de máscaras poderia ser mais vantajosa do que a adoção das opções propugnadas por outros países, não se assiste a campanhas de informação por via da televisão, por exemplo, explicitando com linguagem e imagética clara e acessível, os cuidados a ter na sua seleção, utilização, manuseamento e descarte. 5 dos 7 inquiridos apontam informaçôes contraditórias, excesso de informação, informação pelo medo, desinformação, etc. Apenas 1 considera que foi positiva. Outro apelida a transmissão de "rápida, mas não clara".

Além disso, enquanto que em Moçambique, por exemplo, foi relatado à Equipa, nas sessóes de partilha realizadas com especialistas, que se privilegiou a mobilização maciça dos meios de comunicaçáo social, Portugal pecou pela falta de informação de clara interpretação, denotando-se que a população foi alvo de divulgaçáo de muitos dados numéricos, estatísticos, de difícil apreensão para o público em geral, ficando particularmente suscetível à desinformação. Dos 4 inquiridos moçambicanos, 3 entendem que a transmissão foi positiva, elogiando o facto de essa ter sido uma grande prioridade política, frisando que os "meios de comunicação social mantiveram o seu normal funcionamento inclusive no decorrer do estado de emergência".

Em Angola, entende-se que a informação tem sido transmitida de forma clara e rápida. Dos 8 inquiridos, apenas um entende que foi negativa. Avaliada como razoável por 2 inquiridos, alerta-se para o facto de os meios de comunicação como a rádio e a televisão não chegarem a toda a população. Houve também um inquirido que considera que há algumas dúvidas sobre a fiabilidade dos números de infeçôes publicitados.

No Brasil, uma das dificuldades inerentes ao combate à SARS-CoV-2 identificadas pelo Professor Doutor Fernando Cupertino ${ }^{17}$, é,

17 Fernando CUPERTINO. Transcrições do Workshop realizado no âmbito do Projeto, subordinado ao Tema: A Pandemia Covid-19 no Espaço da Lusofonia, retificadas e aprovadas pelo Orador. 
precisamente, a inexistência de uma rede de informação eficaz através da comunicaçáo social, designadamente apta a fornecer informaçóes educativas à população. Os inquiridos apontam o dedo ao Governo, que se mostrou ineficiente a divulgar informação de uma forma clara e apreensível, propugnando a adoção de comportamentos cientificamente condenáveis, assim como menosprezando o potencial pandémico da SARS-CoV-2, que dificultou a adoção de medidas eficazes de prevenção da transmissão, como, desde logo, o distanciamento social. Fala-se na inexistência de um "plano de comunicação, nacionalmente coordenado, que possa refletir um pensamento uníssono das autoridades sanitárias.". A opinião dos inquiridos espelha esta opinião: 11 de 15 brasileiros entende que houve divulgação de informaçóes contraditórias, de forma não tempestiva, agravada por ser de difícil apreensão e não ter, muitas vezes, a necessária base científica.

Na RAEM, verificou-se grande mobilização dos meios de comunicação para transmitirem publicidade institucional, alertando a população para a necessidade de adoção de práticas essenciais de etiqueta respiratória, incluindo orientaçôes sobre a correta utilização de máscaras, lavagem das mãos, higienização de espaços, assim como explicitando a forma como os meios de rastreio digital devem ser utilizados. Em outubro de 2020, um estudo da Macao Polling Research Association $^{18}$, que inquiriu meio milhar de residentes, chegou à conclusão que $95 \%$ da população estava satisfeita, em geral, com o desempenho do Governo durante a Pandemia e, em particular, com a forma como as autoridades comunicaram com a população, transmitindo as necessárias recomendaçóes. 5 dos 6 inquiridos avalia a disseminação de informação de forma positiva, com informação clara, complet a e atualizada, identificando-se até, nas palavras de um inquirido, um "excesso de zelo".

Para aliviar os problemas relacionados com a divulgação de informação, foi noticiado, em março de 2021, que o Governo português estava empenhado neste assunto, tendo criado uma Task Force de cientistas para melhorar a comunicação sobre a Pandemia. Da população geral de inquiridos que respondeu à questão (38), as críticas a informações

18 Juliana Qi Xuan YUNCG, , et al., Towards a Dialogic Approach: Crisis Communications and Public Reactions in the World's Most Densely Populated City to Tackle COVID-19, Asian Journal for Public Opinion Research, Volume 8, Issue 3, 2020, pp. 265-296 
contraditórias (26\%), demoradas (13\%) e de difícil apreensão (18\%), foram as prevalentes, pelo que a Equipa recomenda que se empreendam esforços para melhorar estes vetores.

Foi relatado à equipa que, embora não faça parte da experiência de nenhum dos países inquiridos, instituir a figura do mediador de pares (ou similar) pode ser um vetor fundamental para ultrapassar situaçóes semelhantes no futuro. Por estarem próximos das comunidades, os mediadores fazem chegar aos cidadãos informaçóes ajustadas à realidade individual e social, podendo até ocupar-se da realização de inquéritos epidemiológicos e exercendo um papel fundamental no apoio a grupos populacionais fragilizados, fazendo-lhes chegar uma resposta célere e personalizada.

Se se olhar às prioridades nos cuidados de saúde durante a primeira onda da pandemia, denota-se que, em Portugal, o SNS privilegiou ${ }^{19} \mathrm{o}$ combate à Covid ${ }^{20}$, o que significou a quebra do número de consultas, cirurgias e deslocaçóes às urgências hospitalares ${ }^{21}$. $\mathrm{Na}$ segunda onda, procurou-se manter o sistema de saúde, tanto quanto possível, em funcionamento. Não obstante, as cirurgias não emergentes, por exemplo, continuam a ser adiadas, pressionando o já frágil SNS.

No Brasil, detetou-se, num primeiro momento, a alocação de recursos para o combate à Covid, que assumiu um caráter prioritário (aumento do número de leitos hospitalares, direcionamento de certas instituiçóes de saúde para tratamento exclusivo de pacientes Covid, instalação de hospitais de campanha, aquisição de EPI e outros equipamentos essenciais, contratação de mão de obra e suspensão das atividades não essenciais). $\mathrm{Na}$ segunda onda, neste país, os inquiridos

19 O impacto desta opção sobre populações vulneráveis, em particular sobre os doentes respiratórios crónicos, foi avaliado pela Equipa, por meio da contribuição da Professora Doutora Isabel Saraiva, representante da Associação Respira, em Portugal, oradora no Workshop realizado no âmbito do Projeto.

20 De acordo com os dados numéricos obtidos pelo Movimento Saúde em Dia, $57 \%$ dos portugueses consideram que a pandemia dificultou o acesso a cuidados de saúde. Para além disso, registaram-se menos 7,8 milhóes de consultas médicas presenciais nos centros de saúde. Em sentido contrário, os contactos médicos não presenciais duplicaram de 2019 para 2020, passando de 9,1 milhóes para 18,5 milhóes. Vide: https://www.saudeemdia.pt/?p=home (último acesso a 26/02/2021).

21 Com dados numéricos detalhados sobre a estas realidades, cfr: André DIAS PEREIRA e, Ana Elisabete FERREIRA. Vitimas Colaterais da Covid-19, Revista Gestâo Hospitalar, N. ${ }^{\text {20 }}$, jan./fev./mar. 2020, pp. 42-47 
indicam que o esforço assentou na implementação do plano de vacinação e concretização do objetivo de aumentar leitos hospitalares.

Em Angola, os objetivos coincidem com os estabelecidos no Brasil. No entanto, menciona-se também o esforço de capacitação de profissionais (que incluiu a contratação de médicos, designadamente cubanos) e um reforço da capacidade laboratorial. Em Moçambique retrata-se uma realidade semelhante: a mitigação do SARS-CoV-2 recebeu atenção prioritária, preparando-se uma resposta específica para esta Pandemia. Em ambos os territórios, na segunda onda, procurou-se reforçar os meios de resposta. Na RAEM, não foi assinalado, pelos inquiridos, nenhum estabelecimento de prioridades, além da informação à população e adoção de medidas preventivas da transmissão intercomunitária da Covid.

Quanto a alteraçôes na prestação de cuidados de saúde, foram detetadas, por alguns inquiridos, esse tipo de situaçôes. Em Moçambique, um inquirido revela, entre as medidas adotadas: "A criaçáo rápida de uma enfermaria de trânsito para pacientes com covid-19; a abertura de enfermarias provisórias isoladas, para pacientes infectados, em alguns serviços do hospital; uso obrigatório de máscara e viseira pelos profissionais de saúde; uso obrigatório de equipamento de proteção nas enfermarias de trânsito; lavagem obrigatória das mãos em todas as entradas do hospital e respectivos serviços, bem como a aferição da temperatura nas entradas de acesso ao hospital; redução do número de visitas às enfermarias por dia; cancelamento de consultas externas e outros procedimentos médicos não urgentes".

Em Angola, foi também reportado o cancelamento de consultas externas e a suspensão de atividade cirúrgica não urgente. Em Portugal, a reprogramação da atividade hospitalar, em termos semelhantes aos acima descritos, bem como modificações ao nível da tomada de decisão nas instituiçóes de saúde, foram retratadas pelos inquiridos.

No Brasil, um inquirido descreve que foram empreendidos esforços para implementar a telemedicina, reforçando os canais de atendimento náo presencial e capacitando os profissionais para se adaptarem a estes meios digitais.

Relativamente à questão de saber se é desejável que alteraçôes se mantenham após a situação pandémica, os inquiridos mostram-se favoráveis a que permaneçam em vigor algumas delas, nomeadamente o reforço de recursos humanos e materiais e a utilização de EPI. 
Em Macau, não foi identificada qualquer alteração a este nível.

Em Portugal, há situaçôes em que os testes de diagnóstico COVID-19 são gratuitos para o cidadão, que correspondem aos casos em que a testagem é recomendada pelo SNS por suspeita (mobilizados critérios clínicos, epidemiológicos, imagiológicos ou laboratoriais) de infeção por SARS-CoV-2. Já tivemos oportunidade de esclarecer que as seguradoras comparticipam algumas formas de testagem (nem sempre comparticipam as modalidades de testagem TRAg e serológicos), quando a indicação de testagem seja dada pelo SNS. A testagem requerida para efeitos de viagens ou realizada por iniciativa particular, regra geral, não é comparticipada pelas seguradoras. Os preços dos testes particulares (do tipo TAAN) fixam-se em cerca de 100 euros, os serológicos 80 euros e os TRAg cerca de 25 euros. Estes valores são considerados, pelos inquiridos, demasiado elevados e não acessíveis ao cidadão comum.

Em Angola, para pessoas em situação de internamento hospitalar, o teste é gratuito. Se o teste for realizado por via de iniciativa particular, é pago. Entende-se que o custo náo é acessível ao cidadão comum, custando entre 6000 a 75000 kwanzas, segundo um inquirido.

Na RAEM, o teste do tipo TAAN é disponibilizado pelo Governo e por 3 entidades particulares (Hospital Universitário, Hospital Kiang Wu, Namyue Group Macao Federation of Trade Unions). Quando são realizados pelos SSM a residentes da RAEM pela primeira vez, os testes são gratuitos. Depois, custam cerca de 180 patacas. São sempre gratuitos para estudantes, menores de 18 anos, maiores de 65 e portadores de certificados de invalidez. O teste custa 90 patacas quando realizado nas agências particulares, valor acessível à população. Os inquiridos consideram os valores dos testes pagos perfeitamente acessíveis para a população do território.

No Brasil, os inquiridos revelam que, apesar de existirem instâncias nas quais o teste pode ser realizado gratuitamente no quadro do SUS, quando são pagos individualmente pelos cidadãos, estão no mercado por preços muito elevados, inacessíveis à população, rondando o montante de R \$ 270,00 (duzentos e setenta reais). Quadro idêntico vigora em Moçambique: havendo situaçóes em que os testes são gratuitos, a totalidade dos inquiridos reporta que estes não são acessíveis à generalidade da população.

Quanto à rastreabilidade digital, foi implementada em Portugal a aplicação digital StayAway COVID, a descarregar voluntariamente 
pelos cidadãos. Embora o Governo tivesse, em outubro de 2020, empreendido esforços para tornar obrigatório recorrer à aplicaçáo, a votação da Proposta foi abandonada ${ }^{22}$. A aplicação não tinha geolocalização e a sua eficácia foi considerada muito baixa: a inscrição de um caso Covid na aplicação tinha de ser feita por médico e só terão sido enviados 2708 alertas de contágio. Depois de se terem inicialmente identificado cerca de três milhóes de utilizadores, em janeiro de 2021 reportava-se que a Aplicação tinha sido apagada por $60 \%$ dos utilizadores ${ }^{23}$.

Na RAEM, foi implementado o "Código de Saúde de Macau", declaração online através da qual são, obrigatoriamente, fornecidos dados relativos ao estado de saúde antes da entrada no território ${ }^{24}$ (números 1 e 2 do artigo $10 .^{\circ}$ da Lei n. ${ }^{\circ} 2 / 2004$ ), ou, voluntariamente, no território da RAEM, acederem a certos estabelecimentos públicos (Correios, Bancos, Serviços da Função Pública, etc.) ou privados. A utilização da declaração exige a submissão digital de dados pessoais identificativos (nome, data de nascimento, e, mais recentemente, morada do utilizador, etc.), suscetíveis de ser divulgados entre departamentos governamentais e que podem ser processados para rastrear doentes e os seus contactos. Depois da introdução dos dados, estes são processados e é atribuído um Código de cor verde (permissáo de entrada), vermelho (proibição) ou amarelo (necessidade de implementação de medidas de auto-gestáo da saúde). No caso de o interessado náo ser portador de um equipamento móvel, existe a possibilidade de o código digital ser substituído por uma declaração em papel. Em março de 2021, foi noticiado que o Código de Saúde passaria a exibir o registo de vacinação dos residentes a quem já teriam sido administradas as duas doses da vacina. Para além dessa novidade, o sistema digital passou a permitir uma gestáo por zonas, criando registos de áreas afetadas por um eventual surto

22 Proposta de Lei n. ${ }^{\circ}$ 62/XIV, Presidência do Conselho de Ministros, de 14 de outubro de 2020, disponível em: https://app.parlamento.pt/webutils/docs/docath $=6148523063446 \mathrm{f} 764 \mathrm{c} 324679595842774 \mathrm{f} 6 \mathrm{a} 63334 \mathrm{e} 7 \mathrm{a} 63766432$ 6c756157357059326c6864476c3259584d7657456c574c33526c6548 $527663793977634777324 d 693159535659755 a 47396 a \&$ fich $=$ ppl62-XIV.doc $\& I n-$ line=true (último acesso a 13/02/2021).

23 Dados do Jornal Público, 15 de janeiro de 2021

24 Vide, por exemplo, o Despacho do Chefe do Executivo n. ${ }^{\circ}$ 120/2020, de 11 de maio, o qual estabelece entre os requisitos de entrada de trabalhadores náo residentes de Macau que sejam residentes do Interior da China, a necessidade de exibirem o Código de Saúde de Macau verde (artigo 1.\%/3)). 
pandémico e sinalizando os residentes com a cor "vermelha", quando as moradas destes coincidam com a zona afetada.

Já no Brasil, são mais fartas as opçóes de mecanismos de rastreio digital disponíveis. Entre as identificadas pela Equipa, destacam-se: Coronavírus SUS, lançado pelo Ministério da Saúde do Brasil (aplicação móvel digital que, para além de fornecer alertas de contacto, divulga informaçóes oficiais sobre a Pandemia, acedendo à geolocalização do equipamento móvel); Guardióes da Saúde (aplicação móvel digital, desenvolvida pela Associação de Profissionais de Epidemiologia de Campo, associada à Universidade de Brasília, que pretende organizar uma base de dados de notificação de casos leves suspeitos de infeção por SARS-CoV-2, com recurso à geolocalização). A utilização destes mecanismos é voluntária. A primeira aplicação conta com cerca de 10 milhóes de downloads (terceira mais utilizada no Mundo), e a segunda cerca de $19 \mathrm{mil}^{25}$.

Em Angola e Moçambique estes mecanismos não foram adotados. Importa destacar, no entanto, e salvaguardado o facto de não se tratar de um mecanismo de rastreio, a mobilização, em Moçambique, de uma ferramenta digital de Auto-Avaliação de Risco Coronavirus (COVID-19), disponível online, na qual os cidadãos podem submeter certos dados, como a idade e sexo, identificar a presença de sintomas do vírus, bem como fatores de risco (como viagens para locais fortemente afetados).

Avaliando a eficácia destes mecanismos, quando adotados, os inquiridos entendem que a eficácia é "muito pouca" (6 de 12 inquiridos que responderam à questão), apontando a falta de adesão de profissionais de saúde e cidadãos como a razão principal para o insucesso desses mecanismos. Foram também apontados receios relativamente ao processamento de dados pessoais. Um inquirido português defende que "Além de reduzida, a sua eficácia é questionável e até perturbadora da resposta, por parte dos serviços de saúde pública”.

No acesso ao tratamento, há protocolos de atuação, procurando-se, no caso português, evitar o critério do "first come, first served" e privilegiando-se o critério do diagnóstico, sem discriminaçáo de género, idade ou condição social. Em todos os países avaliados, parece claro que têm sido mobilizados os critérios da idade, diagnóstico

25 Dados disponíveis em: https:/www.poder360.com.br/coronavirus/conhecaos-aplicativos-de-rastreamento-da-covid-19-usados-pelos-paises/ (acesso a 04/03/2020). 
(designadamente, refere um inquirido brasileiro, a intensidade da sintomatologia respiratória) e risco (presença de comorbidades).

Relativamente à questão de saber se os profissionais de saúde têm acesso prioritário a diagnóstico e tratamento contra a SARS-CoV-2, foi apontado, por quase todos os inquiridos, a existência destas prioridades (dos 32 inquiridos que responderam a esta questão, 81\% identificam a existência de pelo menos uma forma de prioridade dada aos profissionais), sendo salientado que estes são, designadamente, privilegiados no acesso à vacinação contra a Covid em todos os países/regiáo administrativa avaliados.

Do universo de 37 inquiridos que responderam a esta questão, cerca de $78 \%$ considera real a possibilidade de vir a existir uma outra Pandemia de igual grandeza destruidora, deixando, alguns deles, pendente a resposta quanto às razóes de ser dessa possibilidade, por falta de conhecimento científico sobre o tema. Entre os fundamentos arguidos, destacam-se, com grande prevalência nas respostas dos inquiridos, o histórico recente das Pandemias no contexto mundial, a globalização (e fenómenos associados, como a frequência das viagens internacionais), alteraçôes climáticas (com identificação de agravantes, como destruição de ecossistemas), o aumento da frequência da transmissão de cadeias virais entre animais e humanos (com destaque, pelos inquiridos brasileiros, para a prática de agropecuária intensiva e consumo de carne em grandes proporçôes), a alteração de padrôes de consumo, manipulação laboratorial de vírus e bactérias (e uso prodigalizado de agentes antibacterianos) e possibilidade de guerra biológica. Em Angola, entende-se que a falta de saneamento básico trará implicaçóes ao nível da frequência de propagação de doenças infeto-contagiosas.

Quanto à declaração de Estado de Calamidade/Emergência/Exceção remetemos a explicitação desta realidade para o artigo da Professora Doutora Ana Raquel Moniz. Em todos os territórios avaliados foi suspenso o direito à circulaçáo dentro e para fora do país/região administrativa. Adotou-se, em Portugal, tanto na primeira como na segunda onda, uma política de confinamento domiciliário (dever de permanência no domicílio). Em Angola, este confinamento, de natureza parcial, durou cerca de 30 dias. Foram igualmente suspensos, nos dois países, os direitos de iniciativa privada, social e cooperativa e a requisição civil, embora não se tivesse, até ao momento, materializado, em Portugal, permanece como possibilidade ao dispor do Governo, nos 
temos do Decreto-Lei n. ${ }^{\circ}$ 637/74, de 20 de novembro (ao abrigo do artigo 62.\%/2 da CRP) ou por invocação da Base 34, número 2, alínea d) da Lei de Bases da Saúde a qual prevê a possibilidade de "Proceder à requisição de serviços, estabelecimentos e profissionais de saúde em casos de epidemias graves e outras situaçôes semelhantes", mobilizando "[...] intervenção das entidades privadas, do setor social e de outros serviços e entidades do Estado" (número 3), no caso de emergências de saúde pública. Em Angola, não foi necessário recorrer à requisição civil. Em Macau, a possibilidade de requisição de bens e serviços está também contemplada na Lei n. ${ }^{\circ} 2 / 2014$, no artigo 25. $\%$ /1/10). Neste território, salienta-se que os inquiridos consideram que houve suspensão de direitos fundamentais (reuniáo, manifestaçáo), embora não tivesse havido a declaração de um estado de exceção. Outros falam na restrição (mas não suspensão) de direitos fundamentais, como a liberdade de circulação.

Em Moçambique, não foi adotado um confinamento propriamente dito, decidindo-se pela imposiçáo de redução de acesso a espaços públicos, suspensão do ensino presencial, imposição de recolher obrigatório (designadamente, em Maputo), introdução de trabalho em regime de rotatividade, encerramento de restaurantes, entre outras medidas limitativas também de eventos privados (Decreto n. ${ }^{\circ} 12 / 2020$, de 2 de abril). Destaca-se, desde logo, o Decreto Presidencial n. ${ }^{o}$ 11/2020, de 30 de março, que procedeu à declaração do Estado de Emergência, por razóes de calamidade pública, prorrogado diversas vezes e o Decreto n. ${ }^{\circ}$ 79/2020, de 4 de setembro, que Declara a Situação de Calamidade Pública e Ativa o Alerta Vermelho.

$\mathrm{Na}$ RAEM, o acesso a espaços públicos (nomeadamente casinos, teatros, ginásios, cinemas, etc.) foi limitado por meio do Despacho do Chefe do Executivo n. ${ }^{\circ}$ 27/2020, de 4 de fevereiro. O acesso aos casinos foi retomado a 20 de fevereiro de 2020 e aos restantes espaços públicos a 2 de março do mesmo ano. Restriçóes foram impostas quanto à entrada no território (por exemplo, vide Despacho do Chefe do Executivo n. ${ }^{\circ}$ 40/2020, que entrou em vigor a 20 de fevereiro, estabelecendo, inclusive, períodos obrigatórios de observação médica antes de concretizar a entrada na RAEM). Através do Despacho do Chefe do Executivo n. ${ }^{\circ} 72 / 2020$ (que entrou e vigor a 18 de março), foi proibida a entrada no território de todos os náo residentes e o Despacho do Chefe do Executivo n. ${ }^{\circ}$ 80/2020 suspendeu todos os serviços de 
transferência do Aeroporto Internacional de Macau (artigo 1.\%/2)). As limitaçóes à circulação derivam dos artigos $100^{\circ}, 14 .^{\circ}$ e $15 .^{\circ}$ da Lei n. ${ }^{\circ} 2 / 2014$. Sublinha-se ainda a imposição de quarentena obrigatória de 21 dias, na chegada ao território, num local designado pelas Autoridades e despesas inerentes a cargo do interessado.

As Forças Armadas portuguesas desempenharam um importante papel no rastreio das infeçóes, tendo montado Hospitais de campanha nas suas instalaçôes, recebido doentes nos seus Hospitais (em janeiro de 2021, já teriam sido aí alojados mais de mil infetados por SARS-CoV-2), destacando-se ainda o contributo do laboratório militar no processamento de testes. Em março de 2021, o Decreto n. ${ }^{\circ} 4 / 2021$, regulando a prorrogação do estado de emergência, estatui, especificamente, no seu artigo $14 .^{\circ}$ que as forças armadas se ocupariam da realização de inquéritos epidemiológicos e rastreio de contactos de doentes com COVID-19. Os inquiridos identificaram como uma das tarefas desempenhadas pelas forças armadas o desenvolvimento e implementação do plano de vacinação, embora nem todos vejam com bons olhos a assumção dessa tarefa pelos militares. Foi sugerido que estes desempenhassem um papel mais ativo na organização logística prática do combate à Covid (gestão de equipamentos, apoio à administraçáo e organizaçáo de centros de vacinação, que é realizada, designadamente, por forças policiais). Além disso, foi criticado o subaproveitamento do potencial de recursos humanos das forças armadas, assim como a decisão tardia de as incorporar na resposta à Pandemia.

Em Angola, destaca-se o papel desempenhado pelos militares náo só a reforçar a defesa e segurança (controlo de fronteiras), mas também, especificamente, na área da Saúde, com relevantes tarefas na área de testagem e tratamento de pacientes. Em Moçambique, os inquiridos entendem que as principais funçóes assumidas foram a fiscalização das medidas restritivas impostas no decorrer do último ano.

Neste contexto, é importante referir os procedimentos de rastreio que, de acordo com os especialistas ouvidos nas oportunidades de partilha realizadas no âmbito do Projeto, têm sido de grande relevância no combate à Pandemia. No Brasil, a função de rastreio é um papel relevante dos agentes comunitários de família, que integram as equipas de Saúde da Família. São eles o elemento de ligação entre as comunidades e os cuidados de saúde primários, em que também se inclui o rastreio de enfermidades e acompanhamento das condiçóes 
crónicas $^{26}$. Em Moçambique, destaca-se a figura do agente comunitário de saúde: estes profissionais ocuparam-se do rastreio da Covid durante o ano de 2020, estando particularmente próximos das populações.

No Brasil, o papel das forças armadas, para além das funções de rastreio e controlo de contactos e, em geral, de apoio à prestação de cuidados de saúde, foi reconhecido por alguns inquiridos como importante na instalação de hospitais de campanha, distribuição de equipamento hospitalar e, em menor escala, produção da controversa hidrocloroquina.

Houve, em Portugal, significativas alteraçôes aos rituais religiosos. Em 2020, o Decreto n. ${ }^{\circ}$ 14-A/2020, de 18 de março, referia que o exercício de alguns direitos ficava "parcialmente suspenso", entre eles a "liberdade de culto, na sua dimensão coletiva" (artigo 4.o/f)). Embora ao longo do mesmo ano os locais de culto tivessem o acesso limitado por necessidade de fixação de um número máximo de presentes, em 2021, o Decreto do Presidente da República n. ${ }^{\circ}$ 6-B/2021 não previa a mesma suspensão parcial da liberdade de culto (artigo 35\%/1/a) - cerimónias religiosas como exceção à proibição de realização de eventos). A opção de suspender a celebração, designadamente, de Eucaristias públicas, foi tomada pela Conferência Episcopal Portuguesa e vigora desde 23 de janeiro de 2021. Com a imposição de dever de recolhimento domiciliário, as deslocaçóes para participação em cerimónias religiosas mantiveram-se autorizadas (artigo 4. ${ }^{\circ} / 2 / \mathrm{k}$ ) do Decreto n. ${ }^{\circ} 3-\mathrm{C} / 2021$, de 22 de janeiro).

Foram registadas alteraçôes em Angola. Em Moçambique, detetou-se o encerramento de lugares de culto, conferência e reunióes religiosas (artigo 15. ${ }^{\circ}$, Decreto n. ${ }^{\circ}$ 12/2020, de 2 de abril). Na RAEM, as celebraçóes religiosas também estiveram suspensas, medida tomada ao abrigo do artigo 25.\%/1/1) da Lei n. ${ }^{\circ}$ 2/2014.

No Brasil, a questão tem de ser avaliada concretamente em cada Estado e tem gerado alguma polémica. Em sentido contrário à autorização de celebração de atividades religiosas presenciais está, por exemplo, a decisão do Tribunal de Justiça do Estado de São Paulo ${ }^{27}$, de março

26 Fernando CUPERTINO. Transcrições do Workshop realizado no âmbito do Projeto, subordinado ao Tema: A Pandemia Covid-19 no Espaço da Lusofonia, retificadas e aprovadas pelo Orador.

27 Tribunal de Justiça do Estado de São Paulo, Ação Civil Pública Cível, Processo Digital no: 1015344-44.2020.8.26.0053, Relator: Randolfo Ferraz de Campos, 
de 2020, da responsabilidade do Juiz Randolfo Ferraz de Campos, a qual estabelece a proibição "de realização de missas, cultos ou quaisquer atos religiosos" sob "[...] pena de multa diária no valor de $\mathrm{R} \$$ 10.000,00 para cada réu.”. Dias depois, a decisão da Primeira Instância, que dera origem a este recurso, foi revogada pelo Presidente do Tribunal de Justiça do Estado de São Paulo. Outras decisóes judiciais no sentido da suspensão do direito de culto foram determinadas nos tribunais do Rio de Janeiro e Porto Alegre. A 25 de março de 2020, o Decreto n. ${ }^{\circ} 10.292 / 20$ passou a definir as atividades religiosas como atividades essenciais, suscetiveís de serem celebradas respeitando os limites e orientaçôes estabelecidos pelo Ministério da Saúde. Os inquiridos reportam, sobretudo, a fixação de uma capacidade máxima de ocupação dos lugares de culto.

Quanto a rituais fúnebres, em Portugal, depois das dificuldades na determinação de critérios de participação nestes rituais (não discriminação de critérios nos casos de funerais de pessoas infetadas com Covid ou não, fixação de números máximos de pessoas e de horas de duração de velórios, num verdadeiro clima de "desumanização da morte"28), o Decreto n. ${ }^{o}$ 3-A/2021 deixa ao critério das autarquias a definição de medidas organizacionais que garantam a inexistência de aglomerados de pessoas e o controlo das distâncias de segurança, prevendo a possibilidade de fixação de números máximos de presenças, salvaguardando a presença de cônjuge ou unido de facto, ascendentes, descendentes, parentes ou afins (artigo 29. ${ }^{\circ}$ ). Detetou-se nos inquiridos portugueses que este aspeto é alvo de muitas críticas: a privaçáo dos familiares se despedirem de doentes hospitalizados e os rituais fúnebres realizados com muitas limitaçóes são apelidados de uma grande "violência" para familiares dos falecidos.

Foram registadas alteraçôes em Angola. Embora a Lei n. ${ }^{\circ}$ 2/14, através do seu artigo $22 .^{\circ}$ preveja medidas especificas de tratamento de cadáveres em contexto de epidemias e doenças infetocontagiosas, náo se tendo verificado qualquer morte por SARS-CoV-19 em Macau, não houve necessidade de implementar essas medidas adicionais. Em

20/03/2020, disponível em: https://www.defensoria.sp.def.br/dpesp/Repositorio/31/ Documentos/Decisao\%20Liminar\%20do\%20TJSP\%20para\%20suspensao $\% 20$ de $\% 20$ cultos $\% 20$ e $\% 20$ missas $\% 20$ pdf.pdf

28 Cfr, André DIAS PEREIRA e, Ana Elisabete FERREIRA. Vitimas Colaterais da Covid-19... 
março de 2020, com o Festival do Ching Ming (culto dos antepassados), os SSM fizeram chegar aos residentes algumas recomendaçôes ${ }^{29}$ destinadas a evitar a propagaçáo do vírus em cemitérios e sepulcros.

Em Moçambique, o artigo 16. ${ }^{\circ}$ do Decreto n. ${ }^{\circ}$ 12/2020, de 2 de abril determinou que número de participantes na realização de cerimónias fúnebres não deve exceder 20 pessoas, assegurado ainda o cumprimento do distanciamento social e sendo obrigatório o uso de máscara. Regime distinto vale para as cerimónias fúnebres de pessoas que padeciam de COVID-19, nas quais o número de participantes não deve exceder 10 pessoas.

O impacto das alteraçôes de rituais religiosos e fúnebres em Portugal, Angola, Moçambique e Brasil é notório. Nestes países, todos os inquiridos que responderam à questão, detetaram alteraçóes substanciais neste aspeto.

Houve ainda uma limitação ao direito de visita a doentes hospitalizados, abrangendo tanto doentes Covid como não-Covid, nas duas fases da Pandemia, em Portugal, sendo que os inquiridos reportam, inclusive, o desacompanhamento de doentes (invisuais e com mobilidade reduzida) em consultas externas e triagens das urgências. A proibição de visitas, relatam os inquiridos, afetou particularmente os doentes internados por período prolongado nos cuidados intensivos e os pacientes institucionalizados. Um inquirido relatou que essa limitação se aplicou "a todos os doentes. As normas e medidas excecionais foram sendo adaptadas pelos conselhos de administração dos hospitais, centros hospitalares e unidades locais de saúde. Foram, no entanto, fornecidos meios técnicos, em vários hospitais, para que o contacto pudesse ser feito através de videoconferência. Nalguns casos até aproximou mais os doentes dos seus familiares.".

No Brasil, foi salientado pelos inquiridos que as grávidas não puderam ser acompanhadas nos partos. A opção das autoridades angolanas foi distinta, optando por excluir o direito de visita a doentes Covid, mantendo, embora com restriçóes, o direito de visita a doentes não-Covid. Em Moçambique, o Decreto n. ${ }^{\circ}$ 12/2020, de 2 de abril, por meio do seu artigo $4 .^{\circ}$, interditou as visitas a doentes Covid,

29 Prevenção da pneumonia causada pelo novo tipo de coronavirus (COVID-19) - Orientaçóes para prestar homenagem ritual aos antepassados, SSM, 23/12/2020, documento disponível em: https://www.ssm.gov.mo/docs/17723/17723_6c70c78a49c241d492540bcf0828c6ae_000.pdf (Último acesso a 03/03/2021). 
reduzindo-se a frequência das visitas aos outros doentes (máximo de duas pessoas por dia, por cada doente). Em Macau, foram detetadas alteraçóes, embora não tenha ficado claro para os inquiridos a que nível foram introduzidas e quem afetaram.

No que diz respeito ao ensino, ao nível do ensino infantil e juvenil (até aos 18 anos), em Portugal, houve alteração nas práticas educacionais, suspendendo-se todas as atividades letivas presenciais. Nenhum nível de ensino se manteve em regime presencial, tanto na primeira onda como na segunda - desde 5 de fevereiro de 2021 (artigo 3\%/2 do Decreto n. 3-D/2021, de 29 de janeiro). Em Angola, no decorrer do Estado de Emergência, todas as instituiçóes de ensino encerraram (Decreto Executivo n. ${ }^{\circ}$ 124/20 de 30 de março, do Ministério da Educação). Posteriormente, no Estado de Calamidade, introduziu-se um regime presencial limitado no ensino superior e médio.

No Brasil, o ensino assumiu a modalidade não presencial (Portaria no 343, de 17 de março de 2020). Em geral, resulta dos questionários que têm sido causados danos terríveis no sistema educativo. Um inquirido testemunha que: "Ao nível do ensino infantil e juvenil (até aos 18 anos) houve alteração nas práticas educacionais/educativas. A educação infantil e fundamental passou longos meses com vedação de aulas presenciais. A rede pública não foi adaptada para o ensino a distância $\mathrm{e}$ não há previsão de retorno das aulas presenciais. Na rede privada, houve período de retomada das aulas presenciais, mas na 2a. Onda foram novamente suspensas. $\mathrm{O}$ ensino médio foi duramente penalizado, sem aulas presenciais há mais de 11 meses e sem previsão de retorno nem na rede pública e nem na rede privada. O ensino universitário também não tem previsão de retorno às atividades presenciais passados mais de 11 meses do início da pandemia."

Em Moçambique também se identificaram substanciais alteraçôes (Decreto n. ${ }^{\circ}$ 12/2020, de 2 de abril), tendo sido suspenso o ensino presencial. A Professora Orquídea Massarongo ${ }^{30}$, oradora no Workshop realizado no âmbito do Projeto, reporta que o acesso a aulas online, sobretudo nas escolas de ensino público, não dispunha de condiçóes para o realizar: mesmo estudantes universitários têm acesso limitado a

30 Orquídea MASSARONGO. Transcriçôes do Workshop realizado no âmbito do Projeto, subordinado ao Tema: A Pandemia Covid-19 no Espaço da Lusofonia, retificadas e aprovadas pela Oradora. 
computadores e internet, fora das cidades. Com o retomar do ensino presencial, em setembro de 2020, denotou-se que as escolas do ensino público não estavam preparadas para funcionar no cenário da Pandemia que exige, entre outras coisas, higienização regular: em muitas das instituiçốes de ensino náo havia sequer acesso a água, a garantia mais básica para higienização das mãos.

$\mathrm{Na}$ RAEM, os estabelecimentos de todos os níveis de ensino estiveram encerrados nos primeiros meses de 2020, tendo sido introduzidas aulas à distância, online. A reintrodução do regime presencial foi feita faseadamente: as aulas do $4 .^{\circ}$ ao $6 .^{\circ}$ ano reiniciaram no dia 25 de maio; as do $1 .^{\circ}$ ao $3 .^{\circ}$ no dia 1 de junho. Os ensinos infantil, especial, secundário e superior retomaram o seu normal funcionamento depois.

Assim, em todos os países e regiáo administrativa estudados, reporta-se que, pelo menos a um determinado ponto do combate à Pandemia, houve uma suspensão do ensino presencial em todos os níveis de ensino.

Para apoiar o sistema educativo infantil e juvenil, a Equipa propóe a adoção de medidas para potenciar o acesso da comunidade educativa a computadores e internet. Propóe-se ainda um plano de reabertura de escolas de proximidade nas áreas do território em que possa existir um número reduzido de crianças por turma/escola, atendendo-se ainda, no encerramento das escolas, à avaliação casuística do número de alunos e dimensão da escola. A Pandemia da SARS-CoV-2 demonstrou ainda a urgência de se reavaliar a atual dimensão das escolas em Portugal, que embora não tenham sido identificadas nesta específica Pandemia como fonte de propagaçáo do vírus, por esta estirpe, em concreto, não afetar particularmente as crianças, sabe-se que outros vírus epidémicos como a estirpe de H1N1 de 2009-2010, podem vitimizar sobretudo jovens.

Entre as medidas propostas pelos inquiridos, ficou clara a necessidade de disponibilização de equipamentos e planos sociais de internet aos estudantes, adoção de ensino combinando as modalidades presencial e não presencial, apoio psicológico, social e financeiro às famílias, manutenção da atividade desportiva, capacitação dos professores para utilização de equipamentos tecnológicos, transmissão de aulas em canal aberto na televisão (proposta pelos inquiridos de Moçambique e Brasil). Referiu-se ainda a necessidade de restruturação, em geral, dos sistemas de educação, para abranger a preparação para situaçóes pandémicas e equiparadas. 
Em Portugal, estudos sobre a saúde mental das crianças e jovens ganharam particular relevância em 2021, com as perspetivas de agravamento da Pandemia e da aferição do impacto de nova suspensão de atividades letivas presenciais na saúde mental deste grupo populacional. A Equipa salienta os realizados pelo Centro de Estudos e Sondagens de Opiniâo (Cesop) da Universidade Católica para o Público e para a RTP, pela Mind - Instituto de Psicologia Clínica e Forense e ainda "Crise Económica, Pobreza e Desigualdades - Relatório sobre Impacto Socioeconómico e Saúde Mental”, publicado pela Ordem dos Psicólogos Portugueses. Muito recentemente tem grande interesse nesta matéria um Estudo intitulado "O Impacto do Confinamento na Academia de Coimbra”, promovido pela Associação Académica de Coimbra (AAC) e no qual transparecem as insuficiências do ensino à distância e o impacto na saúde mental trazido pelas restrições impostas com a Pandemia ${ }^{31}$. Em Angola, Moçambique e na RAEM, os inquiridos desconhecem, em geral, qualquer estudo nesta matéria.

No Brasil, destacam-se 3 estudos organizados pelo Instituto de Pesquisa Econômica Aplicada (Ipea) e a Organizaçáo Internacional do Trabalho (OIT), centrados em averiguar o impacto da Pandemia no mercado de trabalho jovem, que destacam o aumento da inatividade, não integração da força de trabalho do país e diminuição da capacitação profissional $^{32}$.

Relativamente à população idosa, em Portugal, poucas ou nenhumas medidas foram institucionalmente adotadas para apoiar este grupo populacional. Em Angola, não há registo de medidas adotadas nesta matéria, à exceção de fomento do isolamento deste grupo populacional e fornecimento de EPI aos lares. Os principais apoios, em Portugal, derivaram do terceiro setor e privados e, ocasionalmente, por autoridades municipais, verificando-se situaçóes de abandono ou isolamento. Entre as realidades que mais afetaram esta população, identificam-se, em particular, o encerramento de Centros de Dia - que, para além de privar os idosos da necessária estimulação e interação social, pressionou mais

31 Jornal Público, 12/02/2021, https://www.publico.pt/2021/02/12/p3/noticia/ confinados-74-alunos-universidade-coimbra-pensaram-desistir-estudar-1950408 (último acesso a 18/02/2021).

32 Mais especificamente sobre a temática da Saúde jovem, cfr. Diene M. CARLOS et al., A saúde do adolescente em tempos da COVID-19: scoping review, Cadernos de Saúde Pública, 36 (8) 28 agosto 2020 
cuidadores e famílias - e a proibição de visitas a lares de idosos e hospitais. Salienta-se que, em Portugal, a população residente em lares contribuiu para o grande número de infeçôes e mortes: à avançada idade somava-se a circunstância de serem um grupo de risco pela presença frequente de comorbidades associadas e a residência em espaços fechados. O isolamento já habitual dos idosos agravou-se com a suspensão de visitas a lares e hospitais e a taxa de mortalidade em lares mantém-se alta pela resistência em adotar sistemas de testagem e regimes de exclusividade dos funcionários destas instituiçóes, com internamento rotativo por equipas, opção que tem sido útil noutros países da Europa ${ }^{33}$. No entanto, um inquirido revela algumas medidas que foram adotadas em lares e que permitiram suavizar o impacto do SARS-CoV-2 nesta população: reforço dos contactos da população idosa à distância, com as famílias e reforço de outras formas de visitas de familiares nas instituiçôes, sem contacto direto, designadamente através de estruturas (como vidros de janelas) transparentes.

Em Moçambique, um inquirido revela o conteúdo do artigo $6 .^{\circ}$ do Decreto n. ${ }^{\circ}$ 26/2020, de 8 de Maio, o qual sujeita a uma "proteção especial" os cidadãos de idade superior a 60 anos, concedendo-lhes uma "prioridade na dispensa da actividade laboral presencial" (número 2 do mesmo artigo) quando o vínculo laboral do cidadão o obrigaria a exercer funçóes presencialmente no decorrer do estado de emergência.

A vacinaçáo prioritária dos idosos é considerada, por grande parte dos inquiridos, a principal (e por vezes única) medida implementada para apoiar esta faixa etária.

O principal Estudo que decorre em Portugal em matéria de avaliação de impacto da SARS-CoV-2 na saúde mental dos idosos é o que está a ser realizado por especialistas do Centro de Investigação em Neuropsicologia e Intervenção Cognitivo-Comportamental da Universidade de Coimbra, por meio do grupo CuidadosaMente ${ }^{34}$.

No que diz respeito ao Acesso ao Medicamento e Ensaios Clínicos de Medicamentos e Vacinas, quanto à existência de ensaios clínicos de

33 André DIAS PEREIRA e Heloísa SANTOS. Reflexóes Éticas e Normativas a Propósito do Artigo: "Direitos Humanos e Mortes Evitáveis", Revista Gestão Hospitalar, N. ${ }^{\circ}$ 21, abril/maio/junho, 2020, pp. 70-76

34 Detalhes do Projeto disponíveis em: https://www.cuidaidosamente.pt/ (último acesso a 14/02/2021). 
vacinas ou de medicamentos para a COVID-19, em Portugal ${ }^{35}$, é de salientar um medicamento experimental à base de células estaminais produzido pela Crioestaminal, empresa de Coimbra, bem como a participação de centros de investigação portugueses nos ensaios clínicos do projeto "Solidarity" da OMS, destinado a recolher dados científicos sobre algumas opçôes de tratamento da SARS-CoV-2. Quanto a vacinas, reportam-se $\mathrm{s}^{36}$ os casos de duas equipas portuguesas que se propuseram avançar com ensaios pré-clínicos no início de 2021 e realizar ensaios clínicos com humanos ao longo do corrente ano. A Equipa é sensível à importância que a genética revelou neste âmbito, permitindo a formulaçáo, em tempo recorde, de vacinas e tratamentos, bem como a identificação e caracterização de novas variantes do vírus. Para além disso, com a interação fortalecida entre genética e Saúde Pública, prevê-se que o direito assuma cada vez mais um papel de destaque nestas questôes, pelo que se recomenda uma especial atençáo aos casos de cedência e venda a terceiros de informaçóes genómicas por agências de investigação ${ }^{37}$.

No Brasil, identificam-se, neste momento, cerca de 20 vacinas em fase preliminar, que não deverão estar disponíveis em 2021. Alguns destes projetos científicos são financiados pelo Governo. Não há registos, em Angola, Moçambique e na RAEM de ensaios clínicos de vacinas ou medicamentos.

No que atem a incentivos a participar em estudos clínicos relativos à COVID-19 nas instituiçóes onde os inquiridos exercem a sua atividade profissional, no universo de inquiridos, há apenas registo de 5 casos em que essa participação foi fomentada (2 no Brasil, 2 em Angola e 1 em Portugal).

35 Atendendo à situação de Pandemia, o INFARMED publicou Medidas excecionais no âmbito da realização de Ensaios Clinicos, durante o periodo de risco para a saúde pública, as quais podem ser consultadas em: https://www.infarmed.pt/documents/15786/3584301/Medidas+excecionais+no+ambito+da+realizacao+de+Ensaios+C IInicos\%2C+durante+o+perIodo+de+risco+para+a+saude+publica/60c07e97-6bb9-a972-df05-20fba160e82d (último acesso a 14/02/2021).

36 Jornal Público, 3/02/2021: https://www.publico.pt/2021/02/03/ciencia/noticia/vacinas-portuguesas-covid19-procuram-dinheiro-testes-humanos-1949013 (último acesso a $14 / 02 / 2021)$.

37 Heloísa SANTOS, A evolução no campo da genética tem sido essencial no combate à pandemia, entrevista dada à Gradiva Publicaçóes. 
O uso off-label (fora da indicação terapêutica prevista na AIM Autorização de Introduçáo no Mercado) de medicamentos no tratamento da COVID-19 é aceite em Portugal: foram reportados casos de utilização de esteroides como a dexametasona, assim como de medicamentos antivirais usados no tratamento de VIH, e a DGS autorizou especificamente o uso de medicamentos prescritos normalmente para o tratamento da malária e ébola. Um inquirido afirmou: "Náo já que no contexto da COVID-19 náo existiu nenhuma evidencia cientifica sólida para sustentar a sua utilização. Existiram ensaios mas foram inconclusivos e demonstraram que não há mais-valias.”.

No Brasil, a população inquirida explica que esta foi uma opção política do Governo, muitas vezes sem comprovação científica a suportar esse uso off-label, sendo tendencialmente mal vista pelos inquiridos, estando em vigor a Orientação do Ministério da Saúde para Manuseio Medicamentoso no Tratamento da COVID 19, que prevê essa utilização. Para os inquiridos dos restantes territórios, a resposta a esta questão não é muito clara.

Em todos os territórios estudados existe um plano nacional de vacinação da população contra a Sars-Cov-2. Há grupos prioritários estabelecidos nestes planos. $\mathrm{O}$ acesso à vacina será gratuito para todos os nacionais/residentes desses países/região.

Em Portugal, Angola e na RAEM a vacinação é voluntária. Quanto à possibilidade de exigência de vacinação como requisito de entrada em Portugal, a apresentação pela Comissão Europeia, no passado dia 17 de março, de um Regulamento com vista à adoção de um Certificado Verde Europeu trará novidades nessa matéria ${ }^{38}$. No Brasil, o Acórdão do Supremo Tribunal Federal no julgamento conjunto das Açóes Diretas de Inconstitucionalidade dos Processos n. ${ }^{\text {os }}$ ADI 6586 e 6587 e do Recurso Extraordinário com Agravo do Processo n. ${ }^{\circ}$ 1267879, afirma a possibilidade de vacinação compulsória dos cidadáos, no superior interesse da saúde pública. Ainda quanto a este aspeto, alguns inquiridos detetam, nos diferentes territórios, que está em estudo a possibilidade de esta vacinação ser obrigatória para certas profissóes ou para ser autorizada a entrada no respetivo país/região administrativa.

38 Disponível, em inglês, em: https://ec.europa.eu/info/files/proposal-regulation-interoperable-certificates-vaccination-testing-and-recovery-digital-green-certificate_ en (último acesso a 19/03/2021) 
Figura 2 - Quadro Comparativo dos Planos de Vacinação

\begin{tabular}{|c|c|c|c|c|c|}
\hline & Angola & Brasil & Moçambique & Portugal & RAEM \\
\hline Base Legal & & $\begin{array}{l}\text { Medida provisó- } \\
\text { ria n. } .^{\circ} 1.026, \text { de } \\
6 \text { de janeiro de } \\
2021\end{array}$ & & $\begin{array}{c}\text { Portaria } \\
\text { n. }{ }^{\circ} 298-\mathrm{B} / 2020\end{array}$ & $\begin{array}{c}\text { Despacho } \\
\text { do Chefe do } \\
\text { Executivo } \\
\text { n. }{ }^{\circ} 27 / 2021\end{array}$ \\
\hline $\begin{array}{c}\text { Data da } \\
\text { Primeira } \\
\text { Inoculaçăo }\end{array}$ & $02 / 03 / 2021$ & $17 / 01 / 2021$ & $08 / 03 / 2021$ & $27 / 12 / 2020$ & $09 / 02 / 2021$ \\
\hline 1. ${ }^{\mathrm{a}}$ Fase & $\begin{array}{l}02 / 2 \text { / } 2021 \\
06 / 2021 \\
\text { - Profissionais de } \\
\text { saúde, serviços } \\
\text { sociais e da or- } \\
\text { dem e segurança } \\
\text { pública; } \\
\text { - Pessoas com } \\
\text { morbilidades de } \\
\text { risco; } \\
\text { - Pessoas de } \\
\text { idade igual ou } \\
\text { superior a } 40 \\
\text { anos (entre estas, } \\
\text { priorizando as de } \\
\text { idade superior a } \\
65 \text { anos e as com } \\
\text { maior probabili- } \\
\text { dade de exposi- } \\
\text { ção ao vírus). }\end{array}$ & $\begin{array}{l}\text { 01/2021 } \\
4 \text { Subfases } \\
\text { PRIMEIRA: } \\
\text { - Trabalhadores } \\
\text { de Saúde; } \\
\text { - Pessoas de } 75 \\
\text { anos ou mais; } \\
\text { - Pessoas de } 60 \\
\text { ou mais anos, } \\
\text { institucionaliza- } \\
\text { das; } \\
\text { - Populaçáo in- } \\
\text { dígena em terras } \\
\text { demarcadas; } \\
\text { - Povos e comu- } \\
\text { nidades tradicio- } \\
\text { nais ribeirinhas; } \\
\text { SEGUNDA: } \\
\text { - Pessoas de } 60 \text { a } \\
\text { 74 anos (priori- } \\
\text { zadas por grupos } \\
\text { de idades); } \\
\text { TERCEIRA: } \\
\text { - Pessoas com } \\
\text { idade igual ou } \\
\text { superior a 18 } \\
\text { anos portadoras } \\
\text { de uma das mor- } \\
\text { bidades previstas } \\
\text { no plano; } \\
\text { QUARTA: } \\
\text { - Professores do } \\
\text { ensino básico ao } \\
\text { superior; } \\
\text { - Forças de se- } \\
\text { gurança e salva- } \\
\text { mento; } \\
\text { - Funcionários } \\
\text { do Serviço Pri- } \\
\text { sional. }\end{array}$ & $\begin{array}{l}\text { - Profissionais de } \\
\text { saúde; } \\
\text { - Idosos que } \\
\text { vivem em lares } \\
\text { e auxiliares que } \\
\text { trabalhem nestas } \\
\text { instituiçóes; } \\
\text { - Forças de De- } \\
\text { fesa e Segurança; } \\
\text { - Pacientes com } \\
\text { diabetes Mellitus }\end{array}$ & $\begin{array}{l}\text { 3 Subfases } \\
\text { PRIMEIRA: } \\
\text { 12/2020 } \\
\text { - Profissionais de } \\
\text { saúde envolvidos } \\
\text { na prestaçáo de } \\
\text { cuidados a doen- } \\
\text { tes; } \\
\text { - Profissionais } \\
\text { das forças arma- } \\
\text { das, forças de } \\
\text { segurança e servi- } \\
\text { ços críticos; } \\
\text { - Profissionais e } \\
\text { residentes em Es- } \\
\text { truturas Residen- } \\
\text { ciais para Pessoas } \\
\text { Idosas e institui- } \\
\text { çóes similares; } \\
\text { - Profissionais e } \\
\text { utentes da Rede } \\
\text { Nacional de Cui- } \\
\text { dados Continua- } \\
\text { dos Integrados } \\
\text { SEGUNDA: } \\
\text { 02/2021 } \\
\text { - Idosos com } \\
\text { mais de } 80 \text { anos; } \\
\text { - Titulares de } \\
\text { cargos políticos } \\
\text { e de órgãos de } \\
\text { soberania (2000 } \\
\text { doses). } \\
\text { TERCEIRA: } \\
\text { - Pessoas de } \\
\text { idade } \geq 50 \text { anos, } \\
\text { com pelo menos } \\
\text { uma das } 4 \text { pato- } \\
\text { logias previstas } \\
\text { no Plano. }\end{array}$ & $\begin{array}{l}\text { - Pessoal da li- } \\
\text { nha da frente das } \\
\text { instituiçóes de } \\
\text { saúde; } \\
\text { - Trabalhadores } \\
\text { nos postos fron- } \\
\text { teiriços; } \\
\text { - Pessoal da li- } \\
\text { nha da frente no } \\
\text { combate à epide- } \\
\text { mia; } \\
\text { - Pessoal da linha } \\
\text { da frente das ins- } \\
\text { tituiçóes de servi- } \\
\text { ços sociais; } \\
\text { - Pessoal docente } \\
\text { e trabalhadores } \\
\text { de instituiçōes de } \\
\text { ensino; } \\
\text { - Trabalhadores } \\
\text { de transportes } \\
\text { públicos; } \\
\text { - Tripulação de } \\
\text { aviação; } \\
\text { - Trabalhadores } \\
\text { em contacto com } \\
\text { alimentos da da } \\
\text { cadeia de frio e } \\
\text { produtos alimen- } \\
\text { tares frescos; } \\
\text { - Motoristas de } \\
\text { carga transfron- } \\
\text { teiriça; } \\
\text { - Tripulaçáo de } \\
\text { navios; } \\
\text { - Trabalhadores } \\
\text { da indústria da } \\
\text { pesca; } \\
\text { - Trabalhadores } \\
\text { da indústria do } \\
\text { turismo e do } \\
\text { jogo; } \\
\text { - Pessoas com } \\
\text { necessidade ur- } \\
\text { gente de se des- } \\
\text { locarem a países } \\
\text { ou regiōes endé- } \\
\text { micas. }\end{array}$ \\
\hline
\end{tabular}




\begin{tabular}{|c|c|c|c|c|c|}
\hline & Angola & Brasil & Moçambique & Portugal & RAEM \\
\hline Base Legal & & $\begin{array}{c}\text { Medida provisó- } \\
\text { ria n. }{ }^{\circ} 1.026, \text { de } \\
6 \text { de janeiro de } \\
2021\end{array}$ & & $\begin{array}{cl}\text { Portaria } \\
\text { n. }{ }^{\circ} 298-B / 2020\end{array}$ & $\begin{array}{c}\text { Despacho } \\
\text { do Chefe do } \\
\text { Executivo } \\
\text { n. }{ }^{\circ} 27 / 2021\end{array}$ \\
\hline $\begin{array}{c}\text { Data da } \\
\text { Primeira } \\
\text { Inoculaçấo }\end{array}$ & $02 / 03 / 2021$ & $17 / 01 / 2021$ & 08/03/2021 & $27 / 12 / 2020$ & $09 / 02 / 2021$ \\
\hline 2. ${ }^{\text {a Fase }}$ & $\begin{array}{l}\text { - Pessoas da fai- } \\
\text { xa etária entre os } \\
16 \text { e } 39 \text { anos de } \\
\text { idade }\end{array}$ & & $\begin{array}{l}\text { - Doentes com } \\
\text { diabetes não } \\
\text { abrangidos na } \\
\text { fase anterior; } \\
\text { - Reclusos e } \\
\text { funcionários das } \\
\text { prisóes; } \\
\text { - Populaçôes } \\
\text { residentes em } \\
\text { centros de aco- } \\
\text { lhimento; } \\
\text { Pessoas a viver } \\
\text { nas zonas urba- } \\
\text { nas, com mais de } \\
50 \text { anos. }\end{array}$ & $\begin{array}{l}04 / 2021 \text { - } \\
\text { - Pessoas de ida- } \\
\text { de } \geq 65 \text { anos (que } \\
\text { não tenham sido } \\
\text { vacinadas previa- } \\
\text { mente); } \\
\text { - Pessoas entre os } \\
50 \text { e os } 64 \text { anos } \\
\text { de idade, inclu- } \\
\text { sive, com pelo } \\
\text { menos uma das } \\
\text { patologias elen- } \\
\text { cadas no Plano. }\end{array}$ & \\
\hline $3 .^{\text {a }}$ Fase & $\begin{array}{l}2022 \\
\text { - Menores de } 16 \\
\text { anos }\end{array}$ & & $\begin{array}{l}\text { - Pessoas em } \\
\text { centros de aco- } \\
\text { lhimento; } \\
\text { - Moradores de } \\
\text { comunidades ru- } \\
\text { rais com mais de } \\
50 \text { anos. }\end{array}$ & $\begin{array}{l}\text { - Toda a restante } \\
\text { populaçáo }\end{array}$ & \\
\hline 4. ${ }^{\mathrm{a}}$ Fase & & & $\begin{array}{l}\text { - Todos os outros } \\
\text { cidadãos, exceto } \\
\text { menores de } 15 \\
\text { anos e mulheres } \\
\text { grávidas }\end{array}$ & & \\
\hline
\end{tabular}

Relativamente à vacinação, não passou despercebida à Equipa a importância do impacto da escassez de vacinas, passível de afetar, em grande medida, sobretudo, Angola e Moçambique, países que albergam populaçóes particularmente vulneráveis e o Brasil, país que tem sofrido com o elevado número de infeções e mortes.

No mesmo sentido do que foi defendido na Declaración de la Redbioética UNESCO ${ }^{39}$, de fevereiro de 2021, a Equipa salienta que as vacinas são um bem comum da Humanidade, e que, no geral, as tecnologias mobilizadas na mitigação da SARS-CoV-2 são bens públicos globais. Compreendida a urgência na quebra de patentes das vacinas, é útil, não obstante, denotar que essa quebra não é garantia de facilidade

39 Declaración de la Redbioética UNESCO, fevereiro de 2021 
de acesso e universalização da administração de vacinas e poderia ser contraproducente.

Avaliando a concreta adoção de medidas práticas e institucionais, a Equipa pode oferecer, em Portugal, o exemplo da Universidade de Coimbra (e a Universidade de Lisboa), que adotou medidas para a proteção dos utentes/utilizadores, mas igualmente dos trabalhadores, instituindo o teletrabalho quando compatível com o exercício de funções, suspendendo, seguindo as orientaçóes do Governo, a atividade letiva presencial e, entre outras medidas, implementando projetos de rastreio da comunidade educativa ${ }^{40}$. Em Angola, entre as medidas identificadas para proteção de trabalhadores, destacam-se a disponibilização de álcool-gel, água e detergente para lavar as mãos, distanciamento suficiente, e medição constante da temperatura corporal. Um inquirido angolano com a área de atividade na Saúde, reporta que: "Uma das maiores dificuldades pretende-se com a insuficiência de meios (máscara, álcool gel, luvas, batas, e outros), obrigando os profissionais ao uso repetido e muitas vezes por tempo maior do que o recomendado.”.

Dos 37 inquiridos que responderam a estas duas questôes, todos assinalaram a adoção de medidas de proteção de utentes/utilizadores e trabalhadores. Relativamente a estes últimos, entre as medidas mais frequentes destacam-se o teletrabalho $(70 \%)$, rotatividade de trabalhadores (37\%), utilização de EPI (76\%) e disponibilização de álcool-gel (51\%). Outras medidas incluem a implementação de rastreios aleatórios, disponibilização de equipamentos digitais, fornecimento de pacotes de internet e telefone, apoio psicológico, medição frequente da temperatura corporal, dispensa de trabalho presencial para trabalhadores com fatores de risco (idade, comorbidades, grávidas e mães de crianças com idade igual ou inferior a 12 anos).

Por fim, quanto à Experiência adquirida na Resposta à Emergência de Saúde Pública Covid-19, os inquiridos, face a uma eventual futura pandemia, apresentaram algumas sugestôes para melhorar a situação nos seus países e instituiçóes: preparação de planos de contingência, realização de simulações de pandemia, e organização de stocks de EPI, entre outras soluçôes preventivas, como investir no setor da saúde, combater a desinformação, valorizar os profissionais de saúde, adotar políticas de

40 Para uma detalhada explanação das medidas adotadas, https://www.uc.pt/covid19 (último acesso a 11/02/2021). 
sustentabilidade, melhorar a prestação de cuidados de saúde primários, implementar mecanismos eficazes de diplomacia internacional para situaçôes pandémicas, descentralizar a tomada de decisão, etc.

Relativamente ao papel desempenhado pelas Comissóes de Ética, em Portugal, o Conselho Nacional de Ética para as Ciências da Vida, tem produzido várias Comunicaçóes com Tomadas de Posição quanto a diferentes aspetos éticos associados à Pandemia, incluindo uma Posição sobre a utilização de Aplicações Digitais Móveis para Controlo da Transmissão da Covid-19 e ainda uma Posição, de caráter mais genérico, sobre a "Situação de emergência de saúde pública pela pandemia Covid-19: Aspetos éticos relevantes". Um inquirido mencionou ainda uma série de Comunicados emitidos pela Ordem dos Médicos, alertando para os problemas enfrentados pelo SNS no decorrer da Pandemia, nomeadamente, para a falta de resposta dada aos doentes não-Covid prioritários. Afirmou o inquirido: "A Ordem dos Médicos criou um Gabinete de Crise para acompanhar a Pandemia. O Conselho Nacional de ética e Deontologia Médica (Órgão Consultivo do Conselho Nacional da OM) emitiu um conjunto de recomendaçóes éticas relacionadas com situações provocadas pela Covid-19. Foram produzidos 2 documentos sobre questóes éticas: um produzido pela Ordem dos Médicos sobre a admissão de doentes em Serviços de Medicina intensivos em contexto de falta de camas e outro produzido pela Comissão de Ética do meu hospital sobre a entrega de resultados de SARS-CoV-2 a profissionais de saúde não médicos.".

No Brasil, destacam-se as contribuiçóes da Comissão Nacional de Ética em Pesquisa (Conep), associada ao Conselho Nacional de Saúde (CNS), prevendo imediatamente uma tramitação de urgência para protocolos de pesquisa sobre a SARS-CoV-2 (Informe à Sociedade, de 31 de janeiro de 2020), emitindo ofícios para adaptar a sua atividade ao contexto Pandémico e fornecendo informaçóes para participantes de pesquisa de vacinas contra a Covid que sejam parte de grupos placebo (27 de janeiro de 2021).

Segundo um inquirido: "vários Conselhos posicionaram-se em relação às questóes ligadas à pandemia COVID-19, dentre os quais o Conselho Federal de Psicologia que regulamentou a prestação de serviços psicológicos por meio de Tecnologia da Informação e da Comunicação em tempos de pandemia. Em verdade, de um modo e de outro, os conselhos de ética posicionaram-se no sentido de orientar os profissionais 
de prestaçáo de serviço no tempo que durasse a pandemia. A Comissão Nacional de Ética em Pesquisa (Conep) orientou o Ministério da Saúde que adotasse determinadas medidas com o objetivo de minimizar os potenciais riscos à saúde e a integridade dos participantes de pesquisas, pesquisadores e membros dos Comitês de Ética em Pesquisa durante a pandemia causada pelo coronavírus SARS-CoV-2 (Covid-19).”.

Na RAEM existe a Comissão de Ética para as Ciências da Vida (artigo $11 .^{\circ}$ da Lei n.o 2/96/M, de 3 de Junho), cuja composição e competências estáo definidas pelo Decreto-Lei n. ${ }^{\circ}$ 7/99/M, de 19 de Fevereiro. Não foram registadas contribuições deste Órgão no contexto da Pandemia.

Apesar de identificadas recomendaçóes e pareceres, alguns inquiridos consideram o contributo destas Comissóes manifestamente insuficiente, sendo desejável que assumam um papel mais central no futuro.

Quanto à atuação de acordo com as recomendaçôes da OMS, relata-se que, embora os países/RA tivessem atuado em conformidade com essas recomendaçôes, a tempestividade dessa atuação variou de país para país, relatando os especialistas da Equipa em Angola e Moçambique que o encerramento de fronteiras, por exemplo, imediatamente após terem sido recebidos os alertas sobre a SARS-CoV-2, terá sido fundamental na mitigação da Pandemia, na sua fase inicial. $\mathrm{Na}$ opinião de alguns inquiridos é reprovável a décalage de tempo entre a emissão de orientaçóes por parte da OMS e a adoção de medidas nos países/RA estudados. Entendem alguns inquiridos que as recomendaçóes da OMS no sentido de reforçar o envolvimento de todos os atores políticos na resposta ao SARS-CoV-2 não foi seguida em Portugal, país no qual a DGS centralizou em si a competência de gestáo e divulgação de informação sobre a Pandemia, relegando para um segundo plano figuras importantes como Associaçôes, os próprios órgãos de administração dos Hospitais e os cidadãos, que têm contributos fundamentais para desenvolver e implementar estratégias de mitigação da Covid. 



\section{BIBLIOGRAFIA}

ACKERMAN, Bruce - "The Emergency Constitution", The Yale Law Journal, Vol. 113, 2004, pp. 1029-1091.

ALBERT, Richard/ROZNAI, Yaniv (Eds.), Constitutionalism under Extreme Conditions: Law, Emergency, Exception, Springer, 2020.

ALEXANDRINO, José Melo - "Devia o direito à liberdade ser suspenso? Resposta a Jorge Reis Novais", Observatório Almedina, 7 de Abril de 2020. (também em Revista do Ministério Público, Número Especial COVID-19: 2020, pp. 79-92)

ANAND, Sudhir/PETER, Fabienne/SEN, Amartya (Eds.) - Public Health, Ethics, and Equity, OUP, Oxford, 2004.

ANDRADE, José Carlos Vieira de, Os direitos fundamentais na Consti-

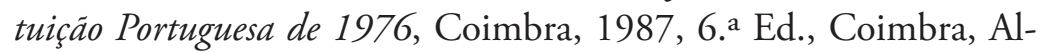
medina, 2019.

ATILES-OSORIA, José/WHYTE, D - "State of Exception, Law and Economy: A socio-legal approach to the economy of exception in an era of crisis", in Oñati Socio-legal Series [online], 8 (6), 2018, pp. 808-818.

BAYERTZ, Kurt/BECK, Birgit, "Soziale Verantwortung Zur Entwicklung des Begriffs im 19. und frühen 20. Jahrhundert". Preprints and Working Papers of the Centre for Advanced Study in Bioethics Münster, 81, Westfälische Wilhelms-Universitäts, Münster, 2015.

BOTELHO, Catarina Santos - "Emergência preventiva, reactiva, cirúrgica, ...reforçada”, Observatório Almedina, 25 de Janeiro de 2021.

BRITO, Miguel Nogueira de - "Modelos de Emergência no Direito Constitucional", e-Pública, Volume 7, N. o 1, Abril, 2020, pp. 6-26. BRONZE, Fernando José, Liçôes de Introdução ao Direito, Coimbra

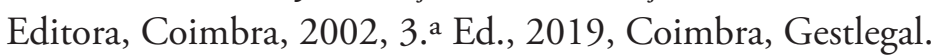


BULMER, Elliot - Emergency Powers, International IDEA Constitution-Building Primer 18, IDEA, Stockholm, 2018.

CANOTILHO, José Joaquim Gomes, Direito Constitucional e Teoria da Constituição, 7. Ed., Coimbra, Almedina, 2003, p. 1161-1162, 1225.

CARLOS, Diene M. et al., A saúde do adolescente em tempos da COVID-19: scoping review, Cadernos de Saúde Pública, 36 (8) 28 agosto 2020

CASTRO, Raquel Brízida de Castro, "Eleiçôes em Estado de Excepção", in Observatório Almedina, 22 de Janeiro de 2021.

CERCEL, Cosmin/FUSCO, Gian Giacomo/LAVIS, Simon (Eds.) States of Exception: Law, History, Theory, Routledge, 2020.

CHASMAN, Deborah \& COHEN, Joshua (Eds.) - The Politics of Care. From Covid 19 to Black Lifes Matter, Boston Review \& Verso Books, 2020.

COGGON, John - "Legal, Moral and Political Determinants within the Social Determinants of Health:. Approaching Transdisciplinary Challenges through Intradisciplinary Reflection", Public Health Ethics, Volume 13, Issue 1, 2020, pp. 41-47.

COGGON, John/SYRETT, Keith/VIENS, A.M. - Public Health Law: Ethics, Governance and Regulation, Routledge, London and New York, 2017.

COLE, David - The Priority of Morality. The Emergency Constitutions Blind Spot", The Yale Law Journal, 113, 2004, 1753 e ss.

CONASS - Volume I - Principais Elementos, Coleção Covid-19, Brasília, 1. ${ }^{a}$ Edição, janeiro de 2021

CONASS - Volume II - Planeamento e Gestão, Coleção Covid-19,

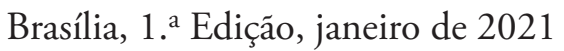

CONASS, Volume III - Competências e Regras, Coleção Covid-19, Brasília, 1. ${ }^{a}$ Edição, janeiro de 2021

CONASS, Volume IV - Profissionais de Saúde e Cuidados Primários, Coleção Covid-19, Brasília, 1. ${ }^{a}$ Edição, janeiro de 2021

CONASS, Volume V - Acesso e Cuidados Especializados, Coleção Covid-19, Brasília, 1. ${ }^{\text {a }}$ Edição, janeiro de 2021

CONASS, Volume VI - Reflexões e Futuro, Coleção Covid-19, Brasília, $1 .^{a}$ Edição, janeiro de 2021

COSTA, José de Faria. Direito Penal, Lisboa: Imprensa Nacional casa da Moeda, 2017, p. $138^{\circ}$ e s.; 
COTULA, Lorenzo - "The state of exception and the law of the global economy: a conceptual and empirico-legal inquiry", Transnational Legal Theory, 8:4, 2017, pp. 424-454.

CRUFT, Rowan/ LIAO, S. Matthew, RENZO/Massimo, The Philosophical Foundations of Human Rights: An Overview, in Rowan Cruft, S. Matthew Liao, Massimo Renzo (Ed.), Philosophical Foundations of Human Rights, Oxford, Oxford University Press, 2015, p. $1-41$.

CUNHA, J. M. Damiāo da, Anotação ao Art. 282º, in: Dias, Jorge de Figueiredo (Dir.), Comentário Conimbricense do Código Penal, Tomo II, Coimbra: Coimbra Editora, 1999, p. 998 e s., p. 999;

CUNHA, J. M. Damiáo da, Anotação ao Art. 283º, in: Dias, Jorge de Figueiredo (Dir.), Comentário Conimbricense do Código Penal, Tomo II, Coimbra: Coimbra Editora, 1999, p. 1006 e s., p. 1007-1008

DYZENHAUS, David - "Schmitt V. Dicey: Are States of Emergency Inside or Outside the Legal Order?”, Cardozo Law Review, Vol 27, p. 2005, 2006

DYZENHAUS, David - The Constitution of Law. Legality in Time of Emergency, Cambridge University Press, Cambridge, New York et al, 2006.

DOUZINAS, Costas, The End of Human Rights, Oxford, Portland, Hart, 2000.

DOUZINAS, Costas/ Warrington, Ronnie, Justice miscarried. Ethics and Aesthetics in Law, Hemel Hempstead, Harvester Wheatsheaf, 1994. EMMONS, Cassandra- "International Human Rights Law and COVID-19 States of Emergency”, VerfassungsBlog, 2020/4/25.

FEREJOHN, John /PASQUINO, Pasquale - "The law of the exception: A typology of emergency powers", International Journal of Constitutional Law, Volume 2, Issue 2, April 2004, pp. 210-239

FRANKENBERG, Günther - Staatstechnik: Perspektiven aufRechtsstaat und Ausnahmezustand, SuhrkampVerlag, Berlin, 2010.

GAUDÊNCIO, Ana Margarida, "Responsabilidade como princípio e limite(s) $\mathrm{da}(\mathrm{s})$ intersubjectividade(s) jurídica(s): reflexôes em torno da proposta de Castanheira Neves", Revista de Direito da Responsabilidade, Ano 2, 2020, p. 771-790 (https://revistadireitoresponsabilidade.pt/2020/responsabilidade-como-principio-e-limites-das-intersubjectividades-juridicas-reflexoes-em-torno-da-proposta-de-castanheira-neves-ana-gaudencio/). 
GONÇALVES, Pedro Costa - "Abdicação parlamentar na emergência e continuação da abdicação na calamidade", Observatório Almedina, 21 de Maio de 2020.

GONÇALVES Pedro, Manual de Direito Administrativo, vol. 1, Almedina, Coimbra, 2019

GOSTIN, Lawrence (Ed.) - Public Health Law and Ethics. A Reader, University of California Press, Berkeley, Los Angeles, London, 2002.

GOUVEIA, Bacelar, "Portugal e a COVID-19: Balanço e Perspetivas de uma Ordem Jurídica da Crise», in: Revista do Ministério Público, número especial COVID-19, ano 41, junho 2020

GOUVEIA, Jorge Bacelar - "O estado de excepção no Direito Constitucional: uma introdução", Observatório Almedina, 26 de Março de 2020 .

GOUVEIA, Jorge Bacelar - Estado de Exceção no Direito Constitucional: Uma Perspetiva do Constitucionalismo Democrático - Teoria Geral e Direito Português, Almedina, Coimbra, 2020

GOUVEIA, Jorge Bacelar - "Portugal e a COVID-19: Balanço e Perspetivas de uma Ordem Jurídica da Crise", in Revista do Ministério Público, número especial COVID-19, ano 41, junho 2020

GOUVEIA, Jorge Bacelar - $O$ Estado de Excepção no Direito Constitucional: Entre a Eficiência e a Normatividade das Estruturas de Defesa Extraordinária da Constituição, vol. II, Almedina, Coimbra, 1998.

GROGAN, Joelle - "Power and the COVID-19 Pandemic - Introduction \& List of Country Reports", VerfassungsBlog, 2021/2/22.

GROSS, Oren/AOLAÍN, Fionnuala Ní - Law in Times of Crisis. Emergency Powers in Theory and Practice, CUP, Cambridge, 2006.

HAARSCHER, Guy, Philosophie des droits de l'homme, Bruxelles, Éditions de l'Université de Bruxelles, 1987 (Ed. revisée 1993).

HEIDBRINK, Ludger/LANGBEHN, Claus/LOH, Janina (Hrsg.), Handbuch Verantwortung, Springer, Wiesbaden, 2017.

HEIDEGGER, Martin, Beiträge zur Philosophie. Vom Ereignis (1936-1938), in Friedrich-Wilhelm von Herrmann (Hrsg.) Gesamtaugabe, III. Abteilung: Unveröffentlichte Abhandlungen, Band 65, Vittorio Klostermann, Frankfurt am Main, 1989, 1994, 2003.

JENNINGS, Bruce/ARRAS, John D./BARRETT, Drue H./ELLIS, Barbara A. (Eds.) - Emergency Ethics. Public Health Preparedness and Response, Oxford University Press, Oxford, 2016. 
JERÓNIMO, Patrícia, Os Direitos do Homem à escala das Civilizaçóes, Coimbra, Almedina, 2001.

KATZ, Rebecca/BANASKI, James (Eds.) - Essentials of Public Health Preparedness and Emergency Management, 2nd Edition, Jones \& Bartlett, Wall Street, 2019.

KLEMENT, Jan Henrik - Verantwortung. Funktion und Legitimation eines Begriffs im Öffentlichen Recht, Mohr Siebeck, Tübingen, 2006. KUO, Ming-Sung - "From Institutional Sovereignty to Constitutional Mindset: Rethinking the Domestication of the State of Exception in the Age of Normalization", ALBERT, Richard/ROZNAI, Yaniv (Eds.), Constitutionalism under Extreme Conditions: Law, Emergency, Exception, Springer, 2020, pp. 21-39

LAKOFF, Andrew - Unprepared. Global Emergency in a Time of Emergency, University of California Press, 2017.

LAKOFF, Andrew. Unprepared: Global Health in a Time of Emergency. University of California Press, August 2017(1st Edition).

Lei de Bases da Saúde: Materiais e Razóes de um Projeto, Cadernos da Lex Medicinae n. ${ }^{\circ}$ 3, Instituto Jurídico | Faculdade de Direito da Universidade de Coimbra, Coimbra, 2018

LEMKE, Matthias - "What does state of exception mean? A definitional and analytical approach", Zeitschrift für Politikwissenschaft, 28, 2018, pp. 373-383.

LEMKE, Matthias (Hrsg.) - Ausnahmezustand. Theoriegeschichte - Anwendungen - Perspektiven, Springer, Wiesbaden, 2017.

LEVINAS, Emmanuel, "Interdit de la représentation et 'droits de l'homme”, in Emmanuel Levinas, Altérité et transcendance, Montpellier, Fata Morgana, 1995 (Le Livre de Poche, 2010), p. 127-135.

LEVINAS, Emmanuel, "Les droits de l'autre homme", in Emmanuel Levinas, Altérité et transcendance, Montpellier, Fata Morgana, 1995 (Le Livre de Poche, 2010), p. 149-153. Emmanuel Levinas, "Droits de l'homme et bonne volonte", in Emmanuel Levinas, Entre nous. Essais sur le penser à l'autre, Paris, Grasset, 1991 (Le Livre de Poche, 2010), p. 215-219.

LEVY, Neil - "Taking Responsibility for Responsibility", in Public Health Ethics, Volume 12, Number 2, 2019, pp. 103-113.

LINHARES, José Manuel Aroso, “Na 'coroa de fumo' da teoria dos princípios: poderá um tratamento dos princípios como normas servir-nos de guia?”, in Fernando Alves Correia, Jónatas E. M. Machado, João 
Carlos Loureiro, Estudos em Homenagem ao Professor Doutor José Joaquim Gomes Canotilho, STVDIA IVRIDICA, 106, Ad Honorem - 6, Volume III - Direitos e interconstitucionalidade: entre dignidade e cosmopolitismo, Coimbra, Coimbra Editora, 2012, 395-421.

LINHARES, José Manuel Aroso, "Validade comunitária e contextos de realização. Anotaçóes em espelho sobre a concepção jurisprudencialista do sistema", 2009, in Revista da Faculdade de Direito da Universidade Lusófona do Porto, 1/1, 2012, 30-35 (https://revistas.ulusofona.pt/ index.php/rfdulp/article/view/2966).

LOMBA, Pedro - "The Constitutionalized State of Emergency. The Case of Portugal”, Verfassungsblog, 15 April, 2020.

LOMBA, Pedro - "Constituição, estado de emergência e Administração sanitária: alguns problemas", in e-Pública, Vol. 7, n. ${ }^{\circ}$ 1, Abril 2020, pp. 27-43.

MARQUES, Mário Reis, "A dignidade humana como prius axiomático", in Manuel da Costa Andrade/Maria João Antunes/Susana Aires de Sousa (Org.), Estudos em Homenagem ao Prof. Doutor Jorge de Figueiredo Dias, vol. IV, Coimbra, Coimbra Editora, 2009, 541$-566,566$.

MARQUES, Mário Reis, "Direitos fundamentais e afirmação de identidades", in Economia e Sociologia, n. o 80, Évora, 2005, p. 157-169.

MARQUES, Mário Reis, Introdução ao Direito I (Figueira da Foz,

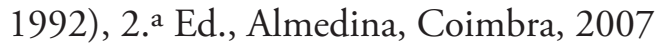

MAY, James R. /DALY, Erin, "Dignity Rights for a pandemic", in Law, Culture and the Humanities, 2020, 1-20 (DOI: 10.1177/1743872120944515).

MINOW, Martha - "The Constitution as Black Box During National Emergencies: Comment on Bruce Ackerman's Before the Next Attack: Preserving Civil Liberties in an Age of Terrorism", Fordham Law Review, 75, pp. 593 (2006).

MIRANDA, Jorge, "Artigo 19. ${ }^{\circ}$ ", in: Miranda, Jorge / Medeiros, Rui (dir.), Constituição Portuguesa Anotada, tomo I, 2. ${ }^{\text {ed., Coim- }}$ bra Editora, Coimbra, 2010

MONTEIRO, Cristina Líbano, Anotação ao Art. 348º, in: Jorge de Figueiredo Dias (Dir.), Comentário Conimbricense do Código Penal, Tomo III, Coimbra: Coimbra Editora, 2001, p. 349 e s., p. 350; Alexandra VILELA (2020)

MOUNK, Yasha - The Age of Responsibility. Luck, Choice, and the Welfare State, Harvard University Press, Cambridge (Ma), London, 2017. 
NEVES, António Castanheira, "A unidade do sistema jurídico: o seu problema e o seu sentido", in Digesta - Escritos acerca do Direito, do pensamento jurídico, da sua metodologia e outros, vol. II, Coimbra, Coimbra Editora, 1995, p. 95-180.

NEVES, António Castanheira, "Coordenadas de uma reflexão sobre o problema universal do Direito - ou as condiçóes da emergência do Direito como Direito", in R. M. Moura Ramos, C. Ferreira de Almeida, A. Marques dos Santos, P. Pais de Vasconcelos, L. Lima Pinheiro, M. Helena Brito, D. Moura Vicente (Org.), Estudos em homenagem à Professora Doutora Isabel de Magalhães Collaço, vol. II, Coimbra, Almedina, 2002, p. 837-871, p. 869-870.

NEVES, António Castanheira, "Justiça e Direito", in Digesta - Escritos acerca do Direito, do pensamento jurídico, da sua metodologia e outros, vol. I, Coimbra, Coimbra Editora, 1995, p. 241-286.

NEVES, António Castanheira, "O direito interrogado pelo tempo presente na perspectiva do futuro", in António Avelâs Nunes/Jacinto de Miranda Coutinho (Coord.), O Direito e o Futuro. O Futuro do Direito, Coimbra, Almedina, 2008, p. 9-82.

NEVES, António Castanheira, "O princípio da legalidade criminal. O seu problema jurídico e o seu critério dogmático", in Digesta Escritos acerca do Direito, do pensamento jurídico, da sua metodologia e outros, vol. I, Coimbra, Coimbra Editora, 1995, p. 349-473.

NEVES, António Castanheira, "Uma reconstituição do sentido do direito - na sua autonomia, nos seus limites, nas suas alternativas", 2009, in Revista da Faculdade de Direito da Universidade Lusófona do Porto, vol. 1, n. ${ }^{\circ}$ 1, 2012 (http://revistas.ulusofona.pt/index.php/rfdulp/ issue/current/showToc, p. 20-21);

NEVES, António Castanheira, Curso de Introdução ao Estudo do Direito: liçóes proferidas a um curso do $10^{\circ}$ ano da Faculdade de Direito de Coimbra, no ano lectivo de 1971-72, Coimbra, 1971-1972.

NIDA-RÜMELIN, Julian/DANIELS, Detlef von/WLOKA, Nicole (Hrsg.), Internationale Gerechtigkeit und institutionelle Verantwortung, De Gruyter, Berlin, 2019.

NOVAIS, Jorge Reis - "Estado de Emergência - Quatro notas jurídico-constitucionais sobre o Decreto Presidencial”, Observatório Almedina, 19 de Março de 2020.

NOVAIS, Jorge Reis - "Direitos Fundamentais e inconstitucionalidade em situação de crise - a propósito da epidemia COVID 19", in e-Pública, Vol. 7., N.o 1 Abril, 2020, pp. 78-117. 
NUSSBAUM, Martha, Creating Capabilities: The Human Development Approach, Cambridge, Harvard University Press, 2011.

O Setor Da Saúde: Organização, Concorrência E Regulação, coord. António Mendes e Francisco André, Caleidoscópio e Confederação Empresarial de Portugal, 2017

OLIVEIRA, Alexandre Au-Yong et al., Jurisdição Penal e Processual Penal, in: CEJ (Org.), Estado de Emergência - COVID-19 - Implicaçóes na Justiça, Lisboa, 2020

OLIVEIRA, Pedro M. L., A importância do terceiro setor na prestação de cuidados de saúde: Exemplo da Região Centro de Portugal, Dissertação para obtençáo do Grau de Mestre em Gestão de Unidades de Saúde, Universidade da Beira Interior, Ciências Sociais e Humanas, fevereiro 2013.

PALMA, Maria Fernanda. Propagação de doença contagiosa, disponível em: https://cidpcc.wordpress.com/2020/04/10/propagacao-de-doenca-contagiosa-por-maria-fernanda-palma/.

PEREIRA André Dias e FERREIRA, Ana Elisabete. Vitimas Colaterais da Covid-19, Revista Gestáo Hospitalar, N. ${ }^{\circ}$ 20, jan./fev./mar. 2020, pp. 42-47

PEREIRA, André Dias e SANTOS, Heloísa., Reflexôes Éticas e Normativas a Propósito do Artigo: "Direitos Humanos e Mortes Evitáveis”, Revista Gestão Hospitalar, N.o 21, abril/maio/junho, 2020, pp. $70-76$

PEREIRA, Rui Soares e GOUVEIA DE CAIRES, João. “Decisão de isolamento profilático como privação da liberdade passível de habeas corpus? - breve comentário ao acórdáo do Tribunal da Relação de Lisboa de 11.11.2020", in Revista da FDUL, ano LXI, 2020, 2, 709-728

PIRCHER, Wolfgang (Hrsg.), Gegen der Ausnahmezustand. Zur Kritik na Carl Schmitt., Springer-Verlag, Wien, 1999.

POGGE, Thomas - World Poverty and Human Rights: Cosmopolitan Responsibilities and Reforms, 2nd ed., Polity Press, Cambridge, 2008

POSNER, Richard - Not a Suicide Pact. The constitution in a time of national emergency, OUP, Oxford, 2006.

RADVANOVSKY, Robert \& MCDOUGALL, Allan - Critical Infrastructure. Homeland Security and, Emergency Preparedness, Fourth Edition, CRC Press, Taylor \& Francis Group, London, New York, 2019 
RAPOSO Vera Lúcia /IONG Man Teng, «The Struggle Against CoViD-19 Pandemic in Macao», in: BioLaw Journal | Rivista di BioDiritto, n. ${ }^{\circ}$ especial $1,2020$.

RAPOSO, Vera Lúcia, Macau, a Luta contra a COVID-19 no Olho do Furação, Cadernos Ibero-Americanos de Direito Sanitário 2020; 9(2) RAZ, Joseph - From Normativity to Responsibility, Oxford University Press, Oxford, 2012.

SANDER, Barrie/RUDALL, Jason (eds.) - COVID-19 and International Law, Opinio Juris Symposium, March 30, 2020.

SANDKÜHLER, Hans-Jörg, "Pluralism, Cultures of Knowledge, Transculturality, and Fundamental Rights", in Hans-Jörg Sandkühler/ Hong-Bin Lim (Ed.), Transculturality: Epistemology, Ethics and Politics, Peter Lang, Frankurt, 2004, p. 79-100.

SCHEPPELE, Kim Lane - "Law in a Time of Emergency: States of Exception and the Temptations of 9/11", Journal of Constitutional Law, Vol. 6, 5, May, 2004, pp. 1001-1083.

SCHMITT, Carl - Die Diktatur. Von den Anfängen des modernen Souveränitätsgedankens bis zum proletarischen Klassenkampf, 1921.

SCHMITT, Carl - Politische Theologie. Vier Kapitel zur Lehre von der Souveränität, 1922.

SELLWOOD, Chloe/WAPLING, Andy (Eds.) - Health Emergency Preparedness and Response, Cabi, Wallingford, Boston, 2016.

SEN, Amartya, Development as Freedom, Oxford, OUP, 1999.

SHAABAN/PELETEIRO/MARTINS, "COVID-19: What Is Next for Portugal?», in: Frontiers in Public Health, vol. 8, 2020, 392 (doi: 10.3389/fpubh.2020.00392).

SIKKINK, Kathryn - Rights and responsibilities in the Coronavirus pandemic, Open Global Rights, 30 March 2020.

SIKKINK, Kathryn - The Hidden Face of Rights: Toward a Politics of Responsibility, Yale University Press, 2020.

SOMBETZKI, Janina - Verantwortung als Begriff, Fähigkeit, Aufgabe. Eine Drei-Ebenen-Analyse, Springer VS, Wiesbaden, 2014

SOUSA, Susana A., A Convenção Medicrime, Lex Medicinae 2019, p. 465 e s., p. 469.

STRONKS, Karien/ TOEBES, Brigit/ HENDRICKS, Aart/ IKRAM, Umar/ VENKATAPURAN, Sridhar - Social justice and human rights as a framework for addressing social determinants of health. Final report of the Task group on Equity, Equality and Human 
Rights. Review of social determinants of health and the health divide in the WHO European Region, WHO Copenhagen, 2016 SUSI, Mart (Ed.), Human Rights, Digital Society and the Law. A Research Companion, Routledge 2019; Council of Europe (Ed.), Human Rights Challenges in the Digital Age: Judicial Perspectives, 2020.

TOEBES, Brigit, "International Health Law: An Emerging Field of Public International Law", in Indian Journal of International Law, 55(3), 2015, p. 299-328 [DOI 10.1007/s40901-016-0020-9].

TRIBE, Laurence/GUDRIGE, Patrick O. - "The Anti-Emergency Constitution", Yale Law Journal, 113, 2004, pp. 1801 e ss

VENKATAPURAM, Sridhar, Health Justice: An Argument for the Capabilities Approach Cambridge/Malden, Polity Press, 2011.

VILELA, Alexandra, COVID-19 e o Direito Penal, in: Godinho, Inês Fernandes / Castro, Miguel Osório de (Eds.), COVID 19 e o Direito, Lisboa: Edições Universitárias Lusófonas, 2020

VILLARREAL, Pedro A. - "Public Health Emergencies and Constitutionalism Before COVID-19: Between the National and the International", in ALBERT, Richard/Yaniv Roznai (Eds.), Constitutionalism under Extreme Conditions: Law, Emergency, Exception, Springer, 2020. pp. 217-238

VILLARREAL, Pedro A. - "Can They Really do That? States' Obligations Under the International health regulations in Light of Covid 19" (Part I e II), in SANDER, Barrie/RUDALL, Jason (eds.) - COVID-19 and International Law, Opinio Juris Symposium, March 30, 2020.

VIOLANTE, Teresa \& LANCEIRO, Rui - "The Response to the COVID-19 pandemic in Portugal: A success story gone wrong", VerfassungsBlog, 04 March 2021.

VIOLANTE, Teresa \& LANCEIRO, Rui, "Coping with Covid-19 in Portugal: From Constitutional Normality to the State of Emergency", VerfassungsBlog, 12 April 2020.

WATERLOT, Ghislain, "Human Rights and the Fate of Tolerance", in Paul Ricoeur (Ed.), Tolerance Between Intolerance and the Intolerable, Providence, Oxford, Berghahn Books, 1996, p. 53-70.

WHO, The World Health Report 2007: Global Public Health Security in the 21st Century, WHO, Geneva, 2007

YAMIN, Alicia Ely - "Post-pandemic collective action for health rights and social justice is essential”, in Open Global Rights, 18 May, 2020. 
YUNCG, Juliana Qi Xuan, et al., Towards a Dialogic Approach: Crisis Communications and Public Reactions in the World's Most Densely Populated City to Tackle COVID-19, Asian Journal for Public Opinion Research, Volume 8, Issue 3, 2020, pp. 265-296 



\section{CONSTITUIÇÁOO DA EQUIPA}

WHO ERC number - (CERC.0079/ HEG 70)

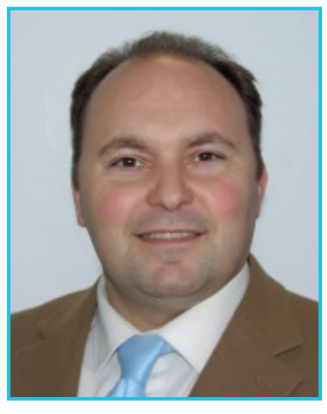

\section{Andlié Dias Pereirra}

[Investigador Principal]

Formação académica:

- Doutor em Ciências Jurídico-Civilísticas pela Universidade de Coimbra (2014)

- Mestre em Ciências Jurídico-Civilísticas pela Universidade de Coimbra (2003)

- Licenciado em Direito pela Universidade de Coimbra (1998)

Profissão:

- Professor auxiliar da Faculdade de Direito da Universidade de Coimbra

- Presidente da Direção do Centro de Direito Biomédico

- Conselheiro do Conselho Geral da Universidade de Coimbra

- Investigador Integrado do Instituto Jurídico - FDUC

Comissôes de Ética:

- Membro do Conselho Nacional de Ética para as Ciências da Vida (2015-2021 e 2021-2026)

- Presidente da Comissão de Ética da AIBILI (Association for Innovation and Biomedical Research on Light) 
- Membro da Comissão de Ética do Instituto Politécnico de Coimbra;

- Membro da Comissão de Ética do Instituto Nacional de Medicina Legal e Ciências Forenses, I.P;

- Membro do Conselho Médico-Legal do Instituto Nacional de Medicina Legal e Ciências Forenses, I.P;

Sociedades científicas internacionais:

- Fellow do European Centre of Tort and Insurance Law;

- Associado Internacional do Instituto Brasileiro de Estudos de Responsabilidade Civil (IBERC);

- Membro da European Association on Health Law;

- Membro da World Association for Medical Law

- Membro do Instituto de Direito Comparado Luso-Brasileiro;

- Membro da Associaçáo Internacional de Direito Comparado (Association internationale de droit comparé/ International Association of Comparative Law);

Ciencia ID: 951E-7E45-3E7F - https://www.cienciavitae.pt/portal/ en/951E-7E45-3E7F

Orcid: 0000-0001-9871-5298 - https://orcid.org/0000-0001-9871-5298 


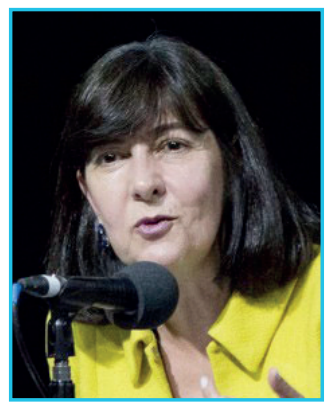

\section{Maria do Céu Patrão Neves [Consultora na Área de Bioética]}

Professora Catedrática de Ética com formação académica em Bioética no Kennedy Institute of Ethics/Georgetown University, Washington DC, onde foi também Visiting Scholar. Tem exercido diversas funçôes em organismos como: consultora do Presidente da República para a Ética da Vida, membro do Conselho Nacional de Ética para as Ciências da Vida e do Conselho de Administraçâo da International Association of Bioethics. Actualmente é perita em Ética da Comissão Europeia e pertence ao Global Ethics Observatory (GEObs), da UNESCO. É “ethics advisor” do European Research Project (H2020) GA869171 B-WaterSmart -Accelerating Water Smartness in Coastal Europe e também do World Health Organization Project Responsibility for Public Health in the Lusophone World. Integra diversos organismos académico-científicos como: o Conselho Nacional de ética para as Ciências da Vida (CNECV), Conselho Consultivo do Instituto de Bioética da Universidade Católica Portuguesa; o Instituto de Saúde Baseada na Evidência (ISBE); o Centre for Toxicogenomics and Human Health (ToxOmics); o Grupo de Direito e Inteligência Artificial, da Católica Research Centre for the Future of Law; a World Emergency COVID19 Pandemic Ethics; a Comissão de Ética do Centro Académico de Medicina de Lisboa (CAML); a Comissão de Ética e igualmente a Entidade de Verificação da Admissibilidade da Colheita para Transplantes (EVA), do Hospital do Divino Espírito Santo, como vice-presidente; a Comissão de Ética da ordem dos Nutricionistas. É Faculty Member da American University of Sovereign Nations/AUSN(USA). Integra os conselhos científicos/editoriais de revistas académico-científicas estrangeiras e é "peer reviewer" de vários Journals internacionais.

ORCID: orcid.org/0000-0001-7246-6182 


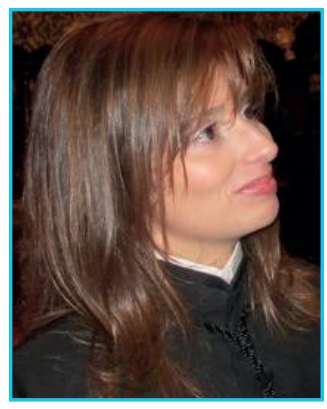

\section{Ana Raquel Gonçallves Moniz}

Professora Associada da Faculdade de Direito da Universidade de Coimbra, onde concluiu a sua Licenciatura, Mestrado e Doutoramento em Direito. É também Investigadora Integrada do Instituto Jurídico da Faculdade de Direito da Universidade de Coimbra. Privilegia, como áreas de investigação, o Direito Administrativo, o Direito Constitucional e a História do Direito Público - áreas onde se centra a sua produção científica, constituída por monografias e estudos incluídos em obras coletivas e publicaçôes periódicas. Entre os livros publicados destacam-se: Introdução à Justiça Constitucional (2021); Os Direitos Fundamentais e a sua Circunstância: Crise e Vinculação Axiológica entre o Estado, a Sociedade e a Comunidade Global (2017); Estudos sobre os Regulamentos Administrativos (2013; 2016); A Recusa de Aplicação de Regulamentos pela Administração com Fundamento em Invalidade: Contributo para a Teoria dos Regulamentos (2012); O Domínio Público: O Critério e o Regime Jurídico da Dominialidade (2005); Responsabilidade Civil Extracontratual por Danos Resultantes da Prestação de Cuidados de Saúde em Estabelecimentos Público: O Acesso à Justiça Administrativa(2003). Foi membro do Conselho Científico (2013-2019) e é Subdiretora (desde 2013) e membro do Conselho Pedagógico (desde 2009) da Faculdade de Direito, e integra ainda o Conselho da Qualidade da Universidade de Coimbra (desde 2013). 


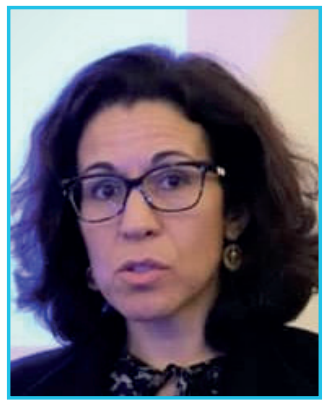

Ana Margariida Simóes Gaudêncio

Professora Auxiliar da Faculdade de Direito da Universidade de Coimbra (Portugal), Investigadora Integrada do Instituto Jurídico da Faculdade de Direito da Universidade de Coimbra, e membro fundador da Associação Portuguesa de Teoria e Filosofia do Direito e de Filosofia Social (secção portuguesa da IVR). As suas principais áreas de investigação são Filosofia do Direito, Teoria do Direito e Metodologia do Direito, principalmente Critical Legal Studies, Tolerância e Direito, Multiculturalismo e Direito e Jurisprudencialismo, com duas monografias (Entre o centro e periferia: a perspectivação ideológico-política da dogmática jurídica e da decisão judicial no Critical Legal Studies Movement, Rio de Janeiro, Lumen Juris, 2013; O intervalo da tolerância nas fronteiras da juridicidade: fundamentos e condiçóes de possibilidade da projecção jurídica de uma (re) construção normativamente substancial da exigência de tolerância, Coimbra, Instituto Jurídico 2019), e diversos artigos em publicaçôes nacionais e internacionais (https://apps.uc.pt/mypage/faculty/anagaude). 


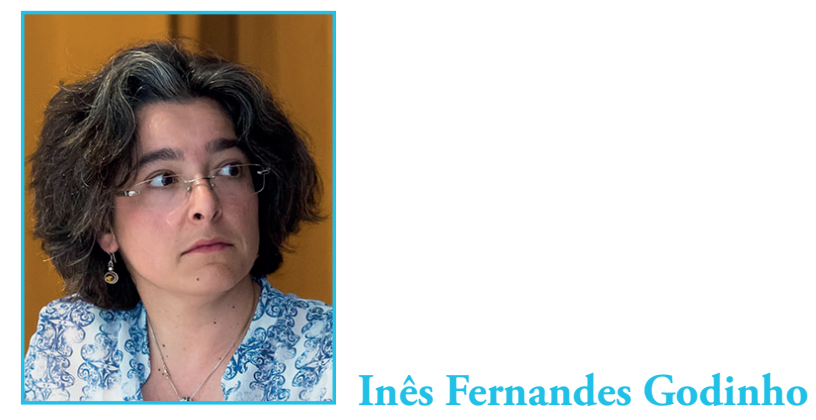

Professora Associada na Universidade Lusófona do Porto. Doutorada em Ciências Jurídico-Criminais pela Universidade de Coimbra em Maio de 2013, é Investigadora do Instituto Jurídico (UC), no qual pertence ao Conselho Coordenador. É ainda associada do Centro de Direito Biomédico, da Ass. Portuguesa de Teoria do Direito, Filosofia do Direito e Filosofia Social e da Fundación Internacional de Ciencias Penales. Em 2016 ganhou um prémio do Max-Planck Institut (Freiburg) e em 2017 foi Professora Convidada na Martin-Luther Universität Halle-Wittenberg, na Alemanha. Foi ainda Bolseira do DAAD no âmbito de um projecto de investigaçáo com a Universidade de Bonn (Alemanha) e Bolseira de Doutoramento da FCT. Enquanto Investigadora realizou diversas estadias de investigação na Alemanha (Bonn e Freiburg) e em Inglaterra (Oxford). Atualmente Diretora da ULP Law Review, é autora de diversos títulos jurídicos, publicados em Portugal e no estrangeiro. 


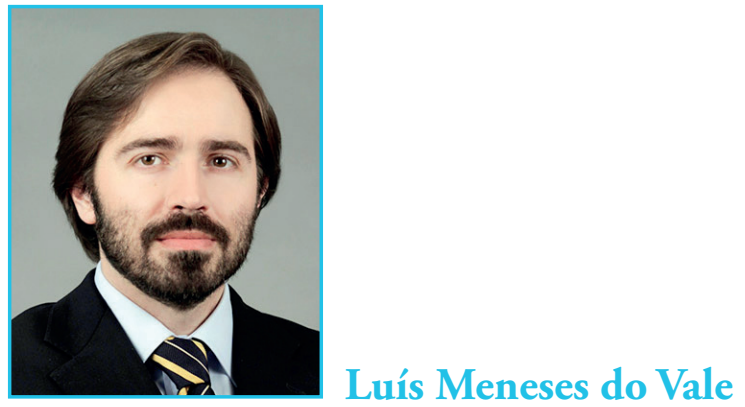

Licenciado pela FDUC, Mestre e Doutor (em ciências jurídico-políticas) pela mesma Faculdade, onde exerce funçóes como Professor Auxiliar, depois de ter sido sucessivamente Monitor, Assistente Estagiário e Assistente, bem como Vogal do Conselho Directivo e do Conselho Pedagógico e Membro e Secretário da Mesa da Assembleia. Docente em cursos de Licenciatura, Pós-Graduação e Mestrado em várias Faculdades da UC e de outras Universidades, é Fundador da ALUMNI, da Associação Portuguesa de Teoria do Direito, Filosofia do Direito e Filosofia Social e do capítulo português da Sociedade Internacional de Direito Público, membro da Associação Portuguesa (e internacional) de Direito Constitucional, da Associação Luso-Alemã de Juristas, investigador associado do Instituto Jurídico e associado do Centro de Direito Biomédico da FDUC. 


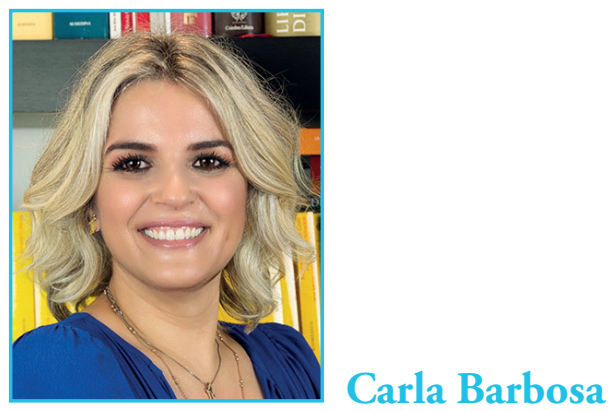

Licenciada em Direito; pós-graduada em Direito da Medicina; Mestre em Direito e Bioética. Advogada com foco de atuação na área do direito da saúde; Off-counsel na área da saúde; Data Protection Officer em empresas ligadas à saúde; Investigadora e associada do Centro de Direito Biomédico da Faculdade de Direito da Universidade de Coimbra; Membro do Conselho Redatorial da Lex Medicinae - Revista Portuguesa de Direito da Saúde; Investigadora do Instituto Jurídico da Faculdade de Direito da Universidade de Coimbra;Membro da Comissão de Ética para a Saúde da ARSCentro; Membro da Comissão de Ética da UICISA; Membro da comissão de aconselhamento para elaboração da norma sobre Consentimento Informado da DGS;Membro do grupo da task force para a elaboração do Plano Nacional para a Segurança do Doente 2021-2026; Membro da 1. ${ }^{\text {a }}$ edição do Health Parliament Portugal (Universidade Nova; Grupo Impresa; Jansen; Microsoft); Docente em diversos Cursos de Licenciatura, Pós-graduação, cursos de Mestrado e Cursos de Doutoramento sobre temas de Direito da Medicina; Participou em diversos colóquios e ciclos de conferências (nacionais e internacionais) sobre temas de direito da medicina e de farmácia e medicamento; Participa em projetos financiados por instituiçôes nacionais e comunitárias quer como investigadora quer no acompanhamento da elaboração das candidaturas e da execução/encerramento os projetos; External expertise em projetos na área da saúde financiados pela Comissão Europeia; Autora e coautora de diversos artigos (em publicaçóes nacionais e internacionais) sobre direito da saúde; coordenadora de diversos livros e revistas sobre direito da saúde. 


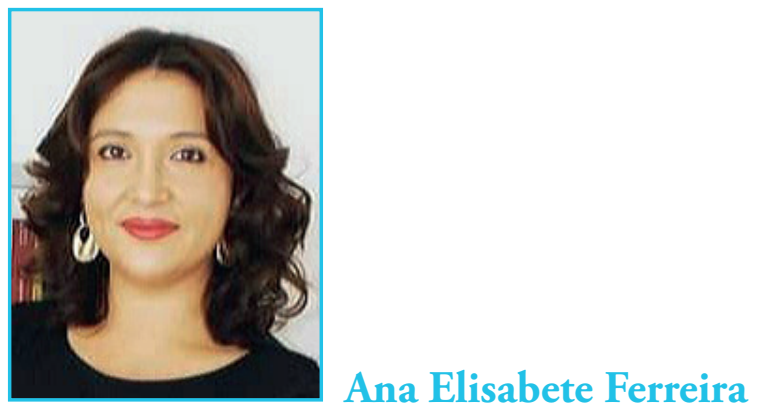

Licenciada e Mestre em Direito pela Faculdade de Direito da Universidade de Coimbra

Doutorada em Bioética pela Universidade Católica Portuguesa

Advogada. Especializaçóes em Direito da Medicina e em Direito da Farmácia e do Medicamento pelo Centro de Direito Biomédico | Portugal

Professora Adjunta convidada na Escola Superior de Tecnologia e Gestão de Leiria

Professora convidada de Bioética na Pontifícia Universidade Católica do Paraná

Investigadora colaboradora do Instituto Jurídico - Faculdade de Direito da Universidade de Coimbra

Responsável pela Secção de Direito Civil Médico do Instituto de Direito Iberoamericano

Conselheira do ORBEA (órgão responsável pelo bem-estar animal) e Biotério da Faculdade de Medicina da Universidade do Porto

Publicou 3 livros na área da Bioética e Direito Médico; possui 38 publicaçôes com «peer review» e participou em 51 eventos, nacionais e internacionais, como «keynote speaker». Recebeu 3 prémios académicos. 


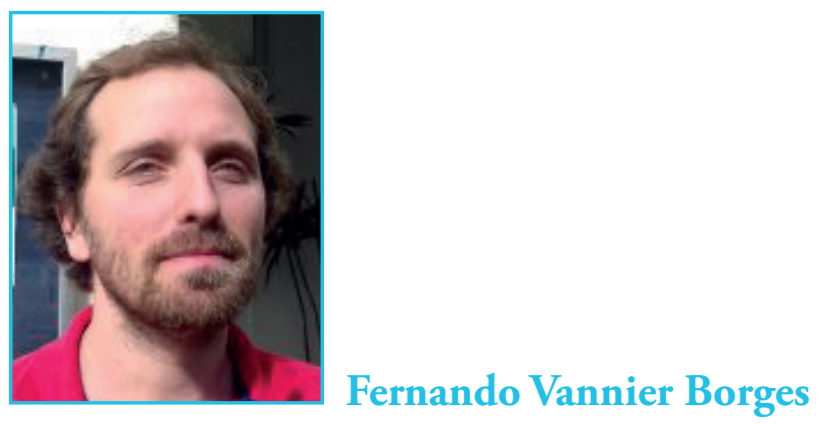

Doutorado em Ciências da Comunicação pela Universidade Panthéon-Assas (Paris II), Mestre em Comunicação e Jornalismo pela Universidade de Coimbra e graduado em Jornalismo pela UFRJ. Atualmente é pesquisador contratado da Universidade de Coimbra, no Instituto Jurídico. Experiências prévias incluem atividades como gestão de ciência e ensino em Cabo Verde e Portugal.

Atualmente tem se focado na comunicação de ciência e no impacto social de projetos de investigação. Com publicações e apresentaçôes sobre a relação entre a Comunicação e o Desporto, seu trabalho prévio se aprofundou nos elementos económicos e simbólicos do espetáculo desportivo, nomeadamente através da criação de canais de media dos clube de futebol.

CV: https:/www.cienciavitae.pt/E617-6159-27F9 


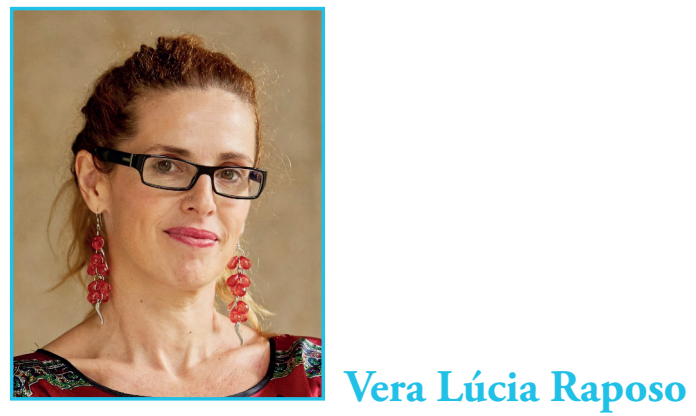

Licenciada em direito, pós-graduada em direito médico, mestre em ciências jurídico-políticas e doutorada também em ciências jurídico-políticas, graus obtidos na Faculdade de Direito da Universidade de Coimbra, Portugal (FDUC).

Actualmente tem um cargo dual: Professora Associada da Faculdade de Direito da Universidade de Macau, China e Professora Auxiliar da FDUC. É investigadora do Centro de Direitos Humanos-Ius Gentium e do Centro de Direito Biomédico, ambos da FDUC. Entre várias outras coisas, foi docente da Faculdade de Direito da Universidade Agostinho Neto, em Angola, e of counsel no escritório Vieira de Almeida e Associados, em Lisboa, na área de direito da saúde.

É autora de vários estudos em português, inglês e espanhol (alguns traduzidos para chinês), em particular sobre direito biomédico e novas tecnologias. 


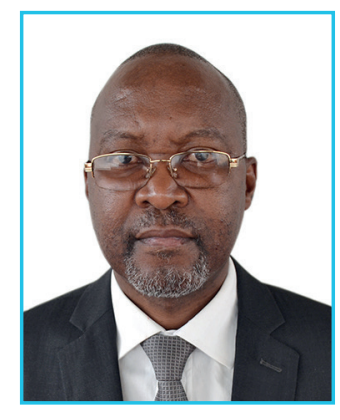

\section{Armindo Gideão Kunjiquisse Jelembi}

A)

- Licenciado em Direito pela Faculdade de Direito da UAN (2003)

- Mestre em Direito Civil pela Faculdade de Direito da UAN (colaboração científica com a Faculdade de Direito da UC; 2008)

- Doutor em Direito Civil pela Universidade de Coimbra (2018-07-30)

- Pós-graduado em agregação pedagógica

- Pós-graduado em direito bancário

- Curso sobre corrupçáo

- Curso sobre cooperação judiciária internacional em matéria Penal

B)

- Professor auxiliar da Faculdade de Direito da Universidade José Eduardo dos Santos

- Regente da cadeira de Direito das Obrigaçóes

- Advogado

C)

- Coordenador adjunto do núcleo da Faculdade de Direito da UAN no Huambo 2005-2009

- Pró-reitor p/cooperação da Universidade José Eduardo dos Santos $2009-2014$

- Vice-reitor p/extensão e cooperação da Universidade José Eduardo dos Santos 2015 -2021 


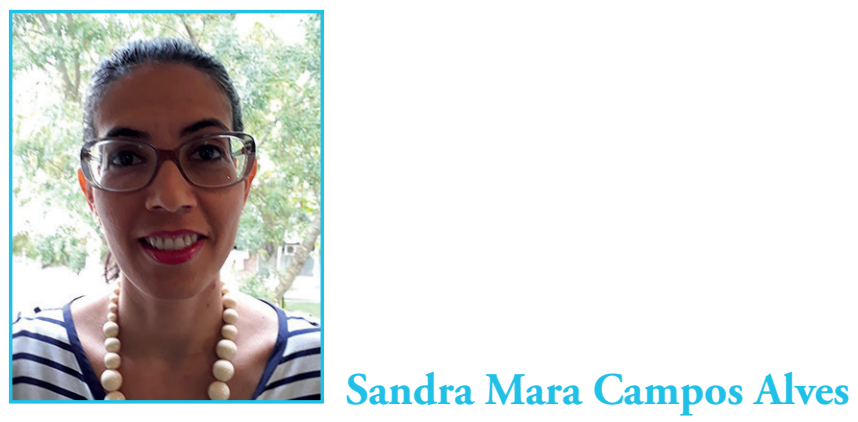

Doutora em Saúde Coletiva (UnB), Mestre em Política Social (UnB), Especialista em Direito Sanitário (Fiocruz), Graduada em Direito (UFC). Pesquisadora e Coordenadora do Programa de Direito Sanitário da Fundação Oswaldo Cruz, Brasília. Docente do Programa de Pós-Graduação em Políticas Públicas em Saúde da Fundação Oswaldo Cruz. Editora chefe do periódico Cadernos Ibero-Americanos de Direito Sanitário. Membro da Aldis (Associação Lusófona do Direito da Saúde) e da Red Iberoamericana de Derecho Sanitario. Autora de livros, capítulos e artigos na área do Direito da Saúde.

E-mail: smcalves@gmail.com

ORCID: https://orcid.org/0000-0001-6171-4558 


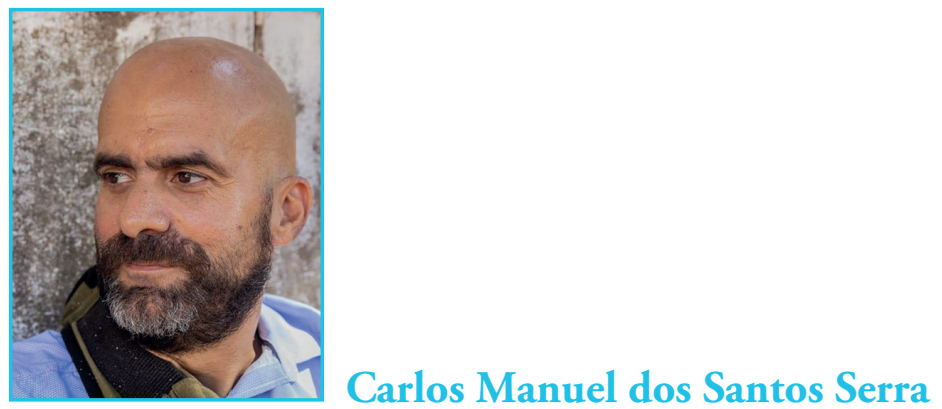

Formação académica:

- Doutorado em Direito Público, pelo Instituto Superior de Ciências e Tecnologia de Moçambique (ISCTEM) e Universidade Nova de Lisboa, 2013;

- Pós-graduado em Direito do Ordenamento, do Urbanismo e do Ambiente, Centro de Estudos do Direito do Ordenamento do Território, do Urbanismo e do Ambiente, Faculdade de Direito da Universidade de Coimbra, 1998;

- Licenciado em Direito, na área jurídico-forense, Faculdade de Direito da Universidade de Coimbra, 1997.

Ocupações/cargos e activismo:

- Membro fundador e Director Geral da Cooperativa de Educação Ambiental Repensar, vocacionada para realização de acçôes de educação e sensibilização ambientais de crianças e jovens;

- Coordenador nacional do Let's Do It Moçambique (que organiza o Dia Mundial da Limpeza);

- Coordenador do Centro de Direito do Ambiente, da Biodiversidade e da Qualidade de Vida (faculdade de Direito da UEM);

- Formador e investigador do Centro de Formação Jurídica e Judiciária (CFJJ) de 2000 a 2013; bem como no Formador convidado do Instituto Nacional de Estudos Judiciários - Angola, entre 2009 e 2014;

- Docente na Universidade Eduardo Mondlane e no Instituto Superior de Ciências e Tecnologia, nos cursos de Direito, de Arquitectura e Engenharia Ambiental de 2002 ao presente momento. 


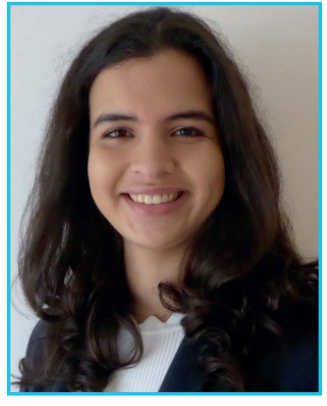

Catarina Zamith de Almeida [Investigadora Júnior]

Licenciada em Direito pela Faculdade de Direito da Universidade de Coimbra. Mestranda em Direito, em Ciências Jurídico-Políticas, com menção em Direito Internacional Público e Europeu. 



\title{
10. ANEXOS
}

\section{A Pandemia Covid-19 no espaço da Lusofonia}

2 de Fevereiro de 2021 - das 14 h às $17 \mathrm{~h} 30$

Instituto Jurídico da Universidade de Coimbra

Portugal

\section{Moderação: Professor Doutor André Dias Pereira, PhD}

Oradores:

\author{
Angola - "A gestão da pandemia SARS-CoV-2 em Angola" \\ Prof. Doutor Cristóvão Simões \\ Reitor da Universidade José Eduardo dos Santos e Médico
}

Brasil - "Aspetos sanitários no Brasil no âmbito da pandemia SARS-CoV-2"

Prof. Doutor Fernando Cupertino

Professor da Faculdade de Medicina da Universidade Federal de Goiás. É assessor técnico do Conselho Nacional dos Secretários de Saúde (Conass), que presidiu por duas vezes. Coordena a Comissão Temática da Saúde, Segurança Alimentar e Nutricional da Comunidade de Países de Língua Portuguesa, desde 2015.

\section{Moçambique - "Visão de Direitos Humanos: o Direito moçambicano"}

Prof. ${ }^{a}$ Doutora Orquídea Massarongo

Professora na Faculdade de Direito da Universidade Eduardo Mondlane e consultora nas áreas do Direito da Saúde e dos Direitos Humanos.

\section{Portugal - "A visão dos doentes do foro respiratório"}

Dr. ${ }^{\text {a }}$ Isabel Saraiva

Presidente da Direção da Respira - Associação Portuguesa de Pessoas com DPOC [Doença Pulmonar Obstrutiva Crónica] e Outras Doenças Respiratórias Crónicas. Foi membro da Direção da EFA - European Federation of Allergies and Airways Diseases (Bruxelas), e perita da EMA - European Medicines Agency (Londres). Entre 2017 e 2020 foi Chair da ELF European Lung Foundation.

\section{Portugal - "O quadro jurídico-administrativo em Portugal"}

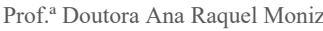

Professora Auxiliar na Faculdade de Direito da Universidade de Coimbra e Investigadora no Instituto Jurídico. 


\title{
Conferência Final
}

Projeto: RESPONSABILIDADE EM SAÚDE PÚBLICA NO MUNDO LUSÓFONO: FAZENDO JUSTIÇA DURANTE E ALÉM DA EMERGÊNCIA DA COVID

\author{
RESPONSIBILITY FOR PUBLIC HEALTH IN THE LUSOPHONE WORLD: DOING JUSTICE IN AND BEYOND \\ THE COVID EMERGENCY
}

WHO ERC number - (CERC.0079/ HEG 70)

25 Março de 2021

9h00-10h00 - Mesa 1 - Mesa de Abertura:

- Vice-Reitor da UC para as Relações Externas e Alumni - Prof. Doutor João Nuno Calvão da Silva

- Presidente do IJ - Prof. Doutor José Manuel Aroso Linhares

- Coordenador da linha Vulnerabilidade e Direito - Prof. Doutor João Loureiro

- Diretor de Cooperação da CPLP (Comunidade dos Países de Língua Portuguesa) - Dr. Manuel Clarote Lapão

10h15-13h00 - Mesa 2 - Análise interdisciplinar dos problemas da Pandemia Covid 19

- Prof.a Doutora Maria Do Céu Patrão Neves (Universidade dos Açores) - Apreciação bioética da luta contra a Covid

- Prof.' Doutora Vera Raposo e Dr. Man Teng Iong (Universidade de Macau) Experiência de Macau contra a Covid-19: do Bem para o Mal

- Prof. Doutor Luís Meneses Do Vale (FDUC, IJ) - Experiências do constitucionalismo em 'Estado de Necessidade'

- Dr. Ricardo Mexia - (ANMSP - Associação Nacional de Médicos Saúde Pública) - "O desafio da pandemia à Medicina de Saúde Pública

- Prof. Doutor Vítor Rodrigues (FMUC, Liga Portuguesa Contra o Cancro) - $O$ problema dos doentes não-Covid, em especial os doentes oncológicos

- Dr. Alexandre Lourenço (APAH - Associação Portuguesa de Administradores Hospitalares) - Desafios da Administração Hospitalar

14h30-15-30 - Mesa 3 - Experiência no hemisfério sul

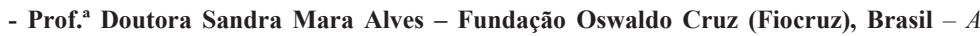
atuação do Congresso Nacional brasileiro frente a pandemia de COVID

- Prof. Doutor Armindo Gideão Jelembi, Universidade José Eduardo dos Santos, Angola - A influência da Covid-19 no funcionamento das instituições universitárias - uma experiência da realidade angolana

- Prof. Doutor Carlos Serra - Universidade Eduardo Mondlane, Moçambique - Direito do Ambiente e Direito Sanitário: a pandemia como linha interseção

15h45-16h30 - Mesa 4 - Balanço do Projeto

- Prof. a Doutora Ana Gaudêncio - Direitos Humanos, Países Lusófonos e a Pandemia Covid

- Prof. Doutor André Dias Pereira - Resultados do projeto

Encerramento 


\section{RECOMENDAÇÓES}

A Equipa do projeto WHO ERC (CERC.0079/ HEG 70), considerando:

(1) A responsabilidade política dos Estados pela estruturação, organização e funcionamento de sistemas de saúde equitativos em sociedades justas;

(2) A previsível intensificação da emergência de doenças infeciosas que, surgindo num local específico, rapidamente se expandem no atual mundo globalizado, com efeitos devastadores ao nível da saúde pública como da generalidade das relaçôes e atividades humanas;

(3) A necessidade de tomada de medidas de prevenção e vigilância, de ação rápida, adequada e proporcional, e de acompanhamento;

(4) O dever, profissional e cívico, de contribuir para a preparação e resposta dos Estados a situaçóes de emergência de saúde pública;

(5) A importância das determinantes sociais, económicas e ambientais na saúde individual e comunitária, bem como nos sistemas de saúde;

(6) A relevância da interseccionalidade e flexibilidade dos sistemas de saúde e da integração da saúde em todas as políticas;

(7) A exigência de que a alocação de recursos de saúde - humanos, técnicos e financeiros -, assim como os critérios de priorização do acesso da população a estes bens vitais, se pautem pelo respeito pelos Direitos Humanos, obedecendo aos princípios éticos estruturantes da dignidade humana, no plano individual, e da justiça social, no plano social;

(8) As diferenças geográficas, socioeconómicas, político-jurídicas e culturais dos países envolvidos neste estudo; 
(9) As diversas realidades constatadas nos ordenamentos jurídicos estudados, e respeitando a sua heterogeneidade;

(10) Os Objetivos de Desenvolvimento Sustentável das Naçôes Unidas de 2030, especialmente os enunciados no ponto 16: "Promover sociedades pacíficas e inclusivas, direcionadas para o desenvolvimento sustentável, proporcionando o acesso universal à justiça e construindo instituiçôes eficazes, responsáveis e inclusivas a todos os níveis",

Apresenta as propostas de abordagem de política pública, visando contribuir para construir sistemas adequados, robustos e resilientes, para responder a dificuldades que emergem em situaçóes de pandemia:

\section{1) Criarir uma lei de vigillância sanitária}

- Essa Lei deve manter o controlo parlamentar sobre a adoção de medidas restritivas de direitos fundamentais (em particular, direitos, liberdades e garantias), conferindo, por sua vez, ao Governo mecanismos ágeis e responsivos para ocorrer a situaçóes de crise pandémica, com integral respeito pela dignidade humana, promovendo mais a vertente preventiva do que a sancionatória, na adopção de uma atitude iminentemente pedagógica.

- Deve ser estudado o papel do Presidente da República, em função da natureza do regime mais presidencialista ou mais parlamentarista de cada país.

- A restrição ou a suspensão dos direitos e liberdades fundamentais deve obedecer ao princípio da proporcionalidade, o qual exige que: a intervenção do Estado se limite ao mínimo necessário e indispensável (na amplitude das medidas e período temporal) para garantir o bem comum; as restriçôes e interdiçóes devem ser cientificamente justificadas e apresentadas com objetividade e transparência (a forma e o conteúdo da intervenção devem estar subordinados e limitados ao fim estabelecido).

\section{2) Reforçar a constituiçáo de equipas de saúde pública e capacitar os seus elementos}

- No Brasil, os profissionais de saúde coletiva não são graduados em Medicina, tendo uma outra formação académica que lhes 
confere o grau de bacharelato/ Licenciatura em Saúde Coletiva. Estes profissionais de saúde coletiva trabalham nas instituiçóes de saúde, assumindo funçôes de cariz administrativo, recomendando uma atuação articulada das diferentes áreas.

- Em Portugal as equipas contam com Médicos especialistas em Saúde Pública, Enfermeiros de saúde comunitária, técnicos de saúde ambiental e ainda, num outro plano, Técnicos de análises clínicas e saúde pública. Deve ser promovido o reforço dos quadros e a sua valorização profissional.

- Recomenda-se o estudo de ambos os modelos para a sua eventual transposição, com as necessárias adaptações, aos países africanos.

3) Preparar as instituiçóes para situaçóes de emergência epidemiológica/pandémica, em especial as instituiçóes de saúde (incluindo os lares residenciais).

- Promover a manutenção de stocks de EPI, nomeadamente máscaras cirúrgicas e álcool-gel e equipamentos de medição da temperatura, pelo menos nas instituições ligadas à prestação de cuidados de saúde.

- Promover a instalação de capacidade nacional para a produçáo de produtos básicos de EPI, incluindo a identificação de empresas capazes de uma rápida reconversão da sua atividade essencial de acordo com as eventuais necessidades durante uma crise pandémica

- As médias e grandes empresas devem manter atualizado um plano de contingência para situaçôes pandémicas (organização do teletrabalho, equipas em espelho, distância física entre trabalhadores, higienização do local de trabalho, etc.).

4) Criar e reforçar a indústria farmacêutica nacional (em cada um dos países), cumprindo os mais elevados padróes de segurança e eficácia dos produtos e de proteçáo dos dados de saúde e dados genéticos de pessoas e comunidades

- Em Portugal e especialmente no Brasil há atividades relevantes no plano da criação de medicamento e realização de ensaios clínicos de medicamentos e vacinas. No Brasil, identificam-se, neste momento, cerca de 20 vacinas em fase preliminar. 
- Deverá ser fortalecida a relação lusófona neste domínio e alargar as capacidades técnicas e científicas aos países africanos.

- É notória a importância que a genética e a inteligência artificial revelaram neste âmbito, permitindo a formulação, em tempo recorde, de vacinas e tratamentos, bem como a identificaçáo e caracterização de novas variantes do vírus. Para além disso, com a interação fortalecida entre genética e Saúde Pública e a conexão digital global, prevê-se que o direito assuma cada vez mais um papel de destaque nestas questóes, pelo que se recomenda uma especial atenção aos casos de cedência e venda a terceiros de informações genómicas por agências de investigação, bem como de proteçáo de dados pessoais.

- É imperiosa uma aposta clara e reforçada na formação académica e na investigação científica de longo prazo (nomeadamente em virologia) e o fortalecimento do financiamento público de pesquisas.

- Cada Estado deve prever um modelo sistemas de responsabilidade civil pelo risco de vacinação.

5) Organizar o sistema de saúde de forma a, em situação epidémi$\mathrm{ca} /$ pandémica, manter a capacidade de cuidar dos doentes não-infectocontagiosos

- Preparar o sistema para situaçóes epidémicas e pandémicas, por forma a garantir a menor perturbação possível dos tratamentos em consulta de ambulatório, cirurgias programadas e atendimento de emergência a doentes não-infectocontagiosos.

- O grande aumento da taxa de mortalidade, em vários países, deve-se mais ao aumento da letalidade por causas não-COVID, do que por infeção SARS-CoV-2. A discriminação dos doentes não-infectocontagiosos é eticamente insustentável.

- A flexibilidade dos sistemas e o desenvolvimento de cuidados integrados é crucial para o enfrentamento de crises pandémicas.

- Deve ser reforçada a digitalizaçáo do sistema de saúde, a par da formação adequada dos profissionais de saúde para potencializarem os seus benefícios em termos de ganhos para a saúde das pessoas e das comunidades. 
6) Melhorar o rigor da informação, a qualidade da comunicação, e o nível de literacia em saúde, incluindo em saúde pública.

- Melhorar a capacidade de transmissão de informação relativa à resposta de emergência de saúde pública COVID-19;

- Estudar um plano de comunicação por parte das autoridades oficiais, com envolvimento da psicologia das organizaçôes e de profissionais da comunicação, que alcance os vários setores da sociedade (idosos, adolescentes, minorias e migrantes).

- Promover a literacia em saúde, com campanhas e açóes práticas de promoção da higiene e promoção de estilos de vida saudáveis, promovendo o envolvimento do setor social e das autarquias locais.

7) Prever, nos termos da Lei, o papel das Forças Armadas e das forças de segurança em situaçóes de emergência epidemiológica/ pandérmica

- As Forças Armadas poderão ter uma importante intervenção em situaçóes de emergência de saúde pública, designadamente: no rastreio das infeçóes, no estabelecimento de hospitais de campanha nas suas instalaçóes, recebendo doentes nos seus hospitais, contribuindo com os laboratórios militares no processamento de testes, na realização de inquéritos epidemiológicos e rastreio de contactos de doentes com COVID-19 e no desenvolvimento e implementação do plano de vacinação.

- Pode ser previsto um desempenho mais ativo das Forças Armadas na organização logística prática aquando de surtos pandémicos (gestão de equipamentos, apoio à administração e organização de centros de vacinação).

- Ser definida e enquadrada a atuação das forças de segurança na prevenção e fiscalização do cumprimento de normas sanitárias em situação pandémica.

8) Reforçar a proteçáo das pessoas mais vulneráveis ao agente infecioso em causa, nomeadamente os idosos, nas suas casas, instituiiçóes e espaços públicos

- Promover o desempenho do terceiro setor e privados e das autoridades municipais e juntas de freguesia no apoio às pessoas mais 
vulneráveis, nomeadamente os idosos, na promoção de hábitos de vida saudáveis e com interação social e intergeracional e na luta contra situaçôes de abandono ou isolamento;

- Evitar o encerramento de Centros de Dia, mas também das instituições de apoio a pessoas portadoras de deficiência que, para além de privar os idosos e as pessoas portadoras de deficiências da necessária estimulação e interação social, pressionou mais cuidadores e famílias.

- Evitar a proibiçáo (total) de visitas a lares de idosos e hospitais e reforçar as ligaçóes, sem contacto direto, designadamente através de estruturas (como vidros de janelas) transparentes.

- Adotar sistemas de testagem frequente nas instituiçóes (Centros de Dia instituiçóes de apoio a pessoas portadoras de deficiência e outras similares).

- Alterar a legislação laboral estabelecendo licenças laborais mais robustas para prestar auxílio a outros membros do agregado familiar que não apenas os filhos (designadamente auxílio a idosos ou pessoas portadoras de deficiência a cargo);

- Alterar a legislação laboral para fomentar regimes de exclusividade dos funcionários nas instituições residenciais e possibilitar o internamento rotativo por equipas.

9) Preservar a vivência afetiva e espiritual das pessoas e comunidades, nomeadamente no que se refere a visitas hospitalares e a instituiçóes residenciais, bem como a rituais religiosos e especificamente fúnebres

- São matérias distintas, mas de grande densidade ética, antropológica e social. Os constrangimentos impostos a estas dimensóes da existência conduzem a uma destruição de sentido e tem efeitos desagregadores da família, das comunidades e da tessitura ética e espiritual da comunidade.

- Uma visão rigorosa do princípio da legalidade e da proporcionalidade deve imperar neste domínio, não permitindo que poderes de facto (dos profissionais de saúde e das empresas lutuosas) se sobreponham ao Estado de Direito e à primazia dos direitos fundamentais. 
10) Preparar os estabelecimentos de ensino, docentes, discentes e famílias, para regimes de ensino adaptados a situaçóes epidémicas/pandémicas, nomeadamente o ensino à distância

- Promover a identificação, por parte dos estabelecimentos de ensino, e no início de cada ano letivo, das condiçóes existentes e ausentes, na comunidade escolar, para o funcionamento das atividades letivas à distância, a fim de suprir as lacunas que se registem.

- Organizar as escolas para situaçóes pandémicas, testando e prevendo situaçóes de: diminuição de tempo em escola, mais intensa higienização regular, criação de competências digitais para as famílias, diminuição dos alunos por turma.

- Propóe-se ainda um plano de reabertura de escolas de proximidade nas áreas do território em que possa existir um número reduzido de crianças por turma/escola, atendendo-se ainda, no encerramento das escolas, à avaliação casuística do número de alunos e dimensão da escola.

- A Pandemia da SARS-CoV-2 demonstrou ainda a urgência de se reavaliar a atual dimensão das escolas, dado que, embora não tenham sido identificadas nesta específica Pandemia como fonte de propagação do vírus - por esta estirpe, em concreto, não afetar particularmente as crianças -, sabe-se que outros vírus epidémicos, como a estirpe de H1N1 de 2009-2010, podem vitimizar sobretudo jovens.

- Necessidade de disponibilização de equipamentos e planos sociais de internet aos estudantes, adoção de ensino combinando as modalidades presencial e não presencial, apoio psicológico, social e financeiro às famílias, manutenção da atividade desportiva, capacitação dos professores para utilizaçáo de equipamentos tecnológicos, transmissão de aulas em canal aberto na televisão.

11) Investir no ordenamento do território e no planeamento urbanístico, bem como na construção de habitaçóes em prol da proteçáo da saúde e prevençáo da doença

- O enclausuramento em casa, além de altamente desigual e prejudicial para pessoas com outras morbilidades, dadas as condi- 
ções do parque habitacional em vários países, é indutor de outras patologias graves, pelo que se impõe a sua mitigação através do desenvolvimento das cidades que ofereçam condiçóes para as pessoas viverem períodos do dia ao ar livre, com o distanciamento devido.

- Os Estados devem assumir a responsabilidade de (1) as pessoas viverem em casas mais saudáveis e (2) morarem nas cidades com maior sustentabilidade ambiental e melhores condiçôes de vida, incluindo para a prática de desporto, devendo, assim, evitar-se a criação de subúrbios sobrepopulados que induzem a grandes fluxos de transportes coletivos e a zonas comerciais com grandes concentraçôes populacionais.

12) Defender a importância da colaboraçáo internacional em matéria de saúde (global) e o respeito pelos padróes internacionais relativos a estados de emergência

- Um último objetivo, que deve ser afirmado no curto prazo, consiste em reforçar a importância de colaborar internacionalmente em matéria de saúde, através de uma revalorização do papel da OMS e do respeito pelas regulaçóes internacionais.

- Urge revalorizar as regras internacionais que visam promover a proteção dos direitos humanos em estados de emergência sanitária, designadamente o artigo $43 .^{\circ}$ do Regulamento Sanitário Internacional, (IHR - International Health Regulations) e o artigo 4. ${ }^{\circ}$ do Pacto Internacional dos Direitos Civis e Políticos, objecto do circunstanciado Comentário Geral n. ${ }^{\circ}$ 29, por parte do Comité de Direitos Humanos, e especificado através dos Princípios de Siracusa sobre as Disposições de Limitação e Revogação do Pacto Internacional de Direitos Civis e Políticos, assim como, a nível continental, o artigo $15 .^{\circ}$ da Convenção Europeia dos Direitos do Homem e o artigo 27. ${ }^{\circ}$ da Convenção Americana sobre direitos humanos. 

Esta publicação é parte da iniciativa da OMS/Ética em Epidemia e foi financiada por FCDO/Wellcome Grant 214711/Z/18/Z

PROJETO APROVADO E FINANCIADO PELA OMS - ORGANIZAÇÃO MUNDIAL DA SAÚDE

WHO ERC number - (CERC.0079/ HEG 70)
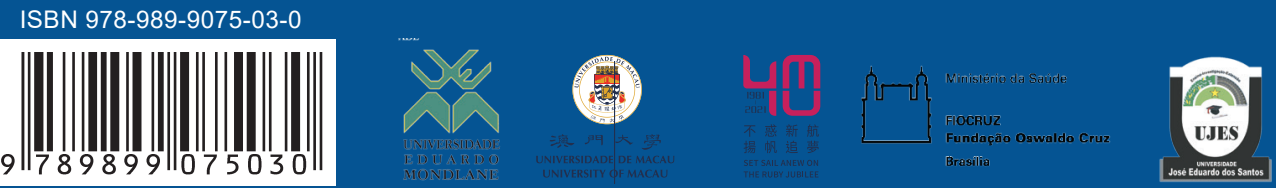